UNIVERSIDADE DE SÃO PAULO

FACULDADE DE FILOSOFIA, LETRAS E CIÊNCIAS HUMANAS

DEPARTAMENTO DE GEOGRAFIA

PROGRAMA DE PÓS-GRADUAÇÃO EM GEOGRAFIA HUMANA

JULIANA COLLI MUNHOZ

A Cartografia Temática aplicada ao turismo e sua fruição no município de São Luiz do Paraitinga (SP)

Versão corrigida. O exemplar original está disponível no CAPH

(Centro de Apoio à Pesquisa Histórica) da FFLCH. 


UNIVERSIDADE DE SÃO PAULO
FACULDADE DE FILOSOFIA, LETRAS E CIÊNCIAS HUMANAS
DEPARTAMENTO DE GEOGRAFIA
PROGRAMA DE PÓS-GRADUAÇÃO EM GEOGRAFIA HUMANA

\title{
A Cartografia Temática aplicada ao turismo e sua fruição no município de São Luiz do Paraitinga (SP)
}

\author{
Juliana Colli Munhoz
}

\begin{abstract}
Dissertação apresentada à Faculdade de Filosofia, Letras e Ciências Humanas da Universidade de São Paulo para obtenção do título de Mestre em Geografia.
\end{abstract}

Orientador: Prof. Dr. Marcello Martinelli

Versão corrigida. O exemplar original está disponível no CAPH

(Centro de Apoio à Pesquisa Histórica) da FFLCH.

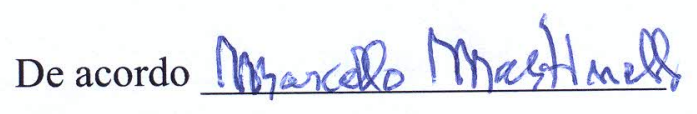


Nome: MUNHOZ, Juliana Colli

Título: A Cartografia Temática aplicada ao turismo e sua fruição no município de São Luiz do Paraitinga (SP).

Dissertação apresentada à Faculdade de Filosofia, Letras e Ciências Humanas da Universidade de São Paulo para obtenção do título de Mestre em Geografia.

Aprovado em:

Banca Examinadora

Prof. Dr. Instituição:

Julgamento:

Assinatura:

Prof. Dr Instituição:

Julgamento:

Assinatura:

Prof. Dr. Instituição:

Julgamento: Assinatura: 
É com amor, gratidão e muita admiração que dedico este trabalho aos meus pais, Valdenice Colli Munhoz e Edson Luiz Duarte Munhoz. 


\section{AGRADECIMENTOS}

Agradeço, sinceramente, meu orientador Prof. Dr. Marcello Martinelli, ao qual expresso minha profunda admiração por sua sabedoria e sensatez, pela relação profícua que desenvolvemos e pelo muito que aprendi ao longo desses anos de convívio.

À Universidade de São Paulo, pela oportunidade de realização do curso de mestrado.

À Secretaria de Pós-Graduação do Departamento de Geografia - FFLCH/USP, pela forma carinhosa como sempre me atenderam.

Ao Prof. Dr. Reinaldo Paul Pérez Machado e a Prof. Dra. Rita de Cássia Ariza da Cruz, pela participação na banca do exame de qualificação, momento que resultou em importantes contribuições ao desenvolvimento do trabalho.

À minha mãe, Valdenice Colli Munhoz, pela sua dedicação e encorajamento, em todos os momentos, colaborando com ideias e pelo companheirismo nos trabalhos de campo.

Ao meu pai, Edson Luiz Duarte Munhoz e ao meu irmão, Fernando Colli Munhoz, pela paciência e incentivo de forma grandiosa na confecção desta pesquisa.

Ao Odonel Urbano Gonçales e a Sandra Mira pelas correções e palavras de carinho.

A toda minha família, minha maior referência de vida.

A todos os funcionários da prefeitura de São Luiz do Paraitinga, em especial ao diretor de turismo Eduardo Coelho, pela atenção e fornecimento de informações.

A toda população de São Luiz do Paraitinga, sempre aberta a conversas e discussões.

Aos meus amigos do trabalho que me apoiaram e suportaram algumas ausências.

Ao querido amigo e geógrafo André de Freitas, pelo companheirismo, sugestões e paciência.

E a todos que direta ou indiretamente também contribuíram para a realização desta dissertação de mestrado. 


\section{RESUMO}

MUNHOZ, Juliana Colli. A Cartografia Temática aplicada ao turismo e sua fruição no município de São Luiz do Paraitinga (SP). 2013. 151f. Dissertação (Mestrado) - Faculdade de Filosofia, Letras e Ciências Humanas, Universidade de São Paulo, São Paulo, 2013.

A cartografia e o turismo têm em comum o espaço geográfico como objeto de estudo. Em síntese, abrangem os elementos e aspectos existentes nas paisagens naturais e sociais. $\mathrm{O}$ turismo, ao desenvolver-se neste espaço, demanda a organização social, provimentos em infraestruturas e o emprego de apreços financeiros por meio de múltiplos estudos e recursos, entre eles, a ciência cartográfica. As informações contidas nos mapas permitem aos turistas e gestores, uma visão geral do espaço geográfico consumido pelo turismo, desde o processo de pesquisa, projetos, marketing, avaliação e até a efetuação de um possível reordenamento territorial. Em especial nas tarefas de planejamento do turismo, a cartografia temática, observada pela representação gráfica, constitui um instrumental de grande utilidade em muitas concepções das atividades turísticas. Nos mapas direcionados para o turismo aconselha-se adotar a Semiologia Gráfica, com o propósito de evitar interferências na comunicação. Optouse, neste trabalho, por pesquisar o turismo como importante vetor na produção do espaço do município de São Luiz do Paraitinga. Dados e informações sobre aspectos demográficos, econômicos e de infraestruturas foram analisados, com enfoque no patrimônio cultural. Para tanto, ressaltou-se sempre a relevância da prática do turismo nas áreas rurais e naturais. A partir deste levantamento, associada à fundamentação teórica atribuída à cartografia temática e ao turismo, foi possível produzir uma coleção de pertinentes mapas analíticos do território luizense. Através da sobreposição destes, elaborou-se um mapa síntese com delimitação e identificação dos tipos de paisagens. As características das unidades espaciais lucubraram possibilidades de detectar áreas passíveis de potencialidades turísticas e especificar os usufrutos das atividades implantadas. Estes fatos subsidiaram uma proposta preliminar de zoneamento turístico, com o intuito de contribuir para a fruição e planejamento do turismo no município.

Palavras-chave: Cartografia Temática, Semiologia Gráfica, Turismo, Tipos de paisagem, Zoneamento turístico. 


\begin{abstract}
MUNHOZ, Juliana Colli. The Thematic Cartography applied to tourism and its fruition in São Luiz do Paraitinga (SP). 2013. 151f. Master's degree tesis - Faculty of Philosophy, Literature and Humanities Sciense, University of São Paulo, São Paulo, 2013.

Cartography and tourism have in common the geographic space as an object of study. In summary, covering the elements and aspects existing in the natural and social landscapes. Developing tourism demands the social organization, provision in infrastructure and the use of financial resources to increment the tourism activity. To attend this requirement multiple methods and studies are applied, among them, the cartographic science. The information contained in the maps allow tourists and managers an overview of the geographical space consumed by tourism, since the process of research, projects, design, marketing, evaluation and even effecting a possible territorial reorganization. Especially in planning tasks, thematic mapping, observed by graphic representation, is a very useful instrument in many conceptions of tourism activities. Maps specific for tourism should apply the Graphic Semiology and avoid interference in communication. In this work, tourism was studied as a major point in the production of space in São Luiz do Paraitinga. Data, demographic, economic and infrastructure information were examined, focusing on cultural heritage. Also, the role of tourism in rural and natural areas development was analyzed. From this survey, coupled with the theoretical foundation attributed to thematic cartography and tourism, a set of relevant analytical maps of the study area was made. Overlapping and grouping these maps enabled the creation of a synthesis map, delimited and identified by the types of landscape. Thus, through critical viewing, was possible to identify the characteristics of areas appropriated for tourism and to underwrite a preliminary proposal for tourism zoning, with the aim of contributing to the enjoyment and tourism planning in the county.
\end{abstract}

Keywords: Thematic Cartography, Graphic Semiology, Tourism, Types of landscape, Tourism zoning. 


\section{LISTA DE FIGURAS}

Figura 01 - Diagrama de Transmissão da Informação Cartográfica .21

Figura 02 - Inserção da representação gráfica em campos mais amplos .24

Figura 03 - Esquema de comunicação monossêmica .25

Figura 04 - As variáveis visuais de Jacques Bertin .26

Figura 05 - Círculo das cores 28

Figura 06 - Combinação das cores 29

Figura 07 - Divisão geral do patrimônio cultural .44

Figura 08 - Pictogramas utilizados pela Michelin no início do século XX

Figura 09 - Atuais pictogramas utilizados pelo Ministério do Turismo

Figura 10 - Mapa dos principais atrativos turísticos de Londres (Inglaterra)

Figura 11 - Trecho do mapa turístico de Canelas (RS)

Figura 12 - Mapa do corredor turístico de Ilha Grande (RJ)

Figura 13 - Mapa turístico do circuito italiano de turismo rural em Colombo (PR). 64

Figura 14 - Mapa turístico de São Luiz do Paraitinga (SP).

Figura 15 - Tipos de mapas na internet

Figura 16 - Hipermapa interativo da Catalunha (Espanha)

Figura 17 - Hipermapa interativo da Catalunha com enfoque na cidade de Barcelona . .72

Figura 18 - Imagem de satélite combinada com dados altimétricos e rede de drenagens........74

Figura 19 - Fluxograma do zoneamento turístico

Figura 20 - São Luiz do Paraitinga: localização 
Figura 21 - Casarios situados ao redor da Praça Oswaldo Cruz em 1930 e 2009

Figura 22 - Vista aérea da enchente em 2010

Figura 23 - Croqui rodoviário e acessibilidade .94

Figura 24 - Capela Nossa Senhora das Mercês, 2003, 2010, 2013. .96

Figura 25 - Delimitação dos Centros Históricos I e II .99

Figura 26 - Grau de proteção dos imóveis tombados 100

Figura 27 - Principais edifícios históricos e culturais 102

Figura 28 - Principais sedes de fazendas históricas 103

Figura 29 - Principais festas tradicionais e populares 104

Figura 30 - Sinalizações turísticas no Núcleo Santa Virgínia

Figura 31 - Mapa do relevo de São Luiz do Paraitinga (SP) representado com isolinhas coloridas em ordem crescente

Figura 32 - Mapa do relevo de São Luiz do Paraitinga (SP) representado por cores hipsométricas com sombreado

Figura 33 - Domínio de mares de morros.

Figura 34 - Mapa hidrográfico de São Luiz do Paraitinga (SP) cujos rios são representados por linhas ordenadas e as bacias com áreas coloridas

Figura 35 - Mapa da cobertura vegetal e uso da terra de São Luiz do Paraitinga (SP) representados por áreas dissociadas pela variável cor

Figura 36 - Mapa de ocupação e distribuição populacional de São Luiz do Paraitinga (SP) por setor censitário, representadas por círculos de tamanhos proporcionais e a respectiva densidade demográfica por ordem visual de cores quentes

Figura 37 - Mapa do sistema viário e meios de hospedagem nas áreas rurais de São Luiz do Paraitinga (SP) cujas estradas são hierarquizadas pela espessura das linhas e cores ordenadas, e as hospedagens dissociadas por feições pontuais coloridas.....

Figura 38 - Mapa das principais fazendas históricas e cachoeiras de São Luiz do Paraitinga (SP) representadas por signos pontuais selecionados pela variação de forma e cor..... 
Figura 39 - Mapa do uso do solo dos centros históricos I e II de São Luiz do Paraitinga (SP) representado por áreas dissociadas pela variável cor...

Figura 40 - Mapa dos principais atrativos turísticos, equipamentos e meios de hospedagem na área urbana de São Luiz do Paraitinga (SP) representados por signos pontuais de diferentes formas e cores contrastantes

Figura 41 - Mapa dos tipos de paisagem de São Luiz do Paraitinga (SP) representados por unidades espaciais organizadas em duas ordens visuais opostas

Figura 42 - Mapa de proposta de zoneamento turístico em São Luiz do Paraitinga (SP) representado por unidades espaciais organizadas em duas ordens visuais opostas..... 140

\section{LISTA DE GRÁFICOS}

Gráfico 01 - Chegadas internacionais e receita cambial do turismo no mundo, 2002-2011....34

Gráfico 02 - Chegadas internacionais e receita cambial do turismo no Brasil, 2002-2011.....34

Gráfico 03 - Desembarques nacionais de turistas nos aeroportos, 2000-2011 .35

Gráfico 04 - Evolução da população, 1936 à 2010 .88

Gráfico 05 - População rural e urbana, 1980, 1990, 2000 e 2010 .89

Gráfico 06 - Taxa de urbanização e ruralização, 1980, 1990, 2000 e 2010 .89

Gráfico 07 - Produto interno bruto da agropecuária, indústria e serviços, 2000 à 2010. .92

Gráfico 08 - Tipo e número de estabelecimentos hoteleiros instalados, 2000 à 2013 .93

Gráfico 09 - Índice Paulista de Responsabilidade Social (IPRS), 2008 e 2010. .96

Gráfico 10 - Comparativo de dados censitários agropecuários, 1995/1996 e 2007/2008. 120 


\section{SUMÁRIO}

INTRODUÇÃ

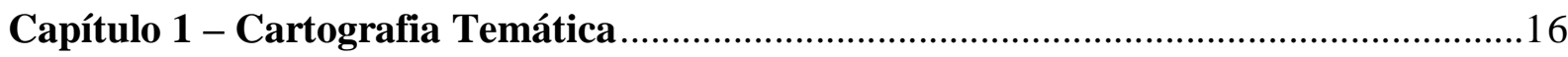

1.1 Breve apanhado sobre a evolução da Cartografia Temática .............................................16

1.2 A Cartografia na busca do reconhecimento como ciência ..............................................19

1.3 Contribuições da Semiologia Gráfica para a Cartografia Temática..................................23

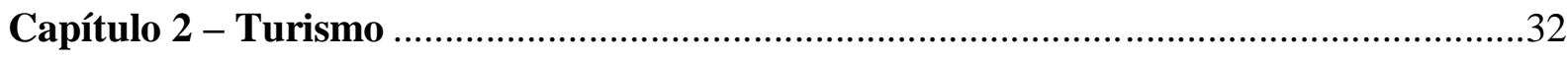

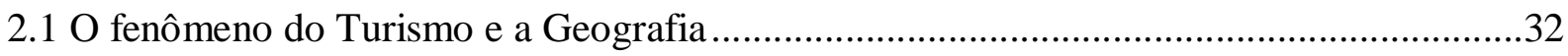

2.1.1 Conceitos de paisagem e sua aplicação nos estudos do Turismo................................38

2.2 Patrimônio Cultural: princípios e conceitos ..................................................................42

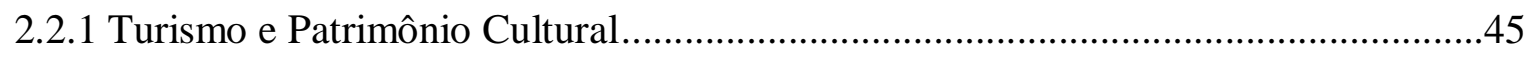

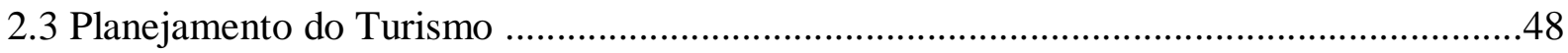

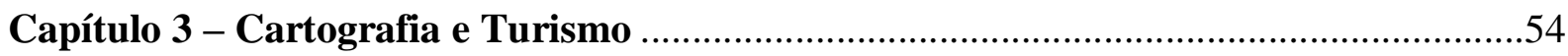

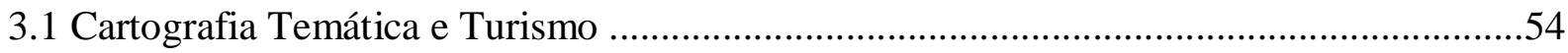

3.2 Novas tecnologias adotadas à Cartografia do Turismo .....................................................67

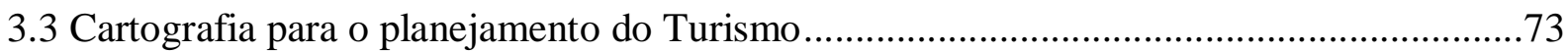

Capítulo 4 - O município de São Luiz do Paraitinga .....................................................79

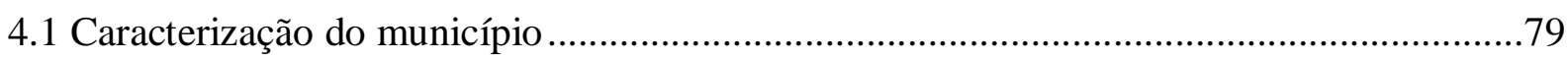

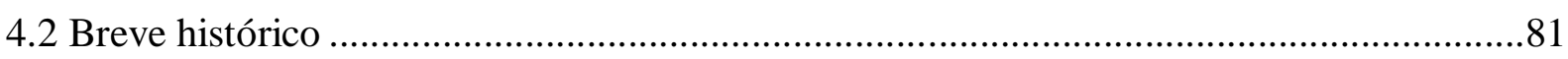

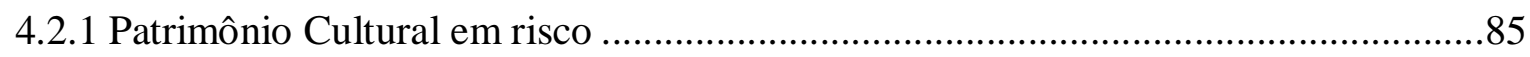

4.3 Demografia, aspectos socioeconômicos e infraestruturas...............................................87 
4.4 Potencialidades e atrativos turísticos

4.5 O Turismo e a refuncionalização do espaço

Capítulo 5 - Cartografia de análise e cartografia de Síntese: tipos de paisagem e proposta de zoneamento turístico para o município de São Luiz do Paraitinga.

5.1 Cartografia de análise

5.2 Cartografia de síntese com delimitação e identificação dos tipos de paisagem

5.3 Sugestão de proposta preliminar para um zoneamento turístico

CONSIDERAÇÕES FINAIS 141

REFERÊNCIAS BIBLIOGRÁFICAS 


\section{INTRODUÇÃO}

Os mapas constituem uma maneira de se comunicar anterior à escrita. É da essência do ser humano o fascínio de observar o espaço por ele ocupado. Isto porque, dentre outras razões, é-lhe próprio e natural preocupar-se com deslocamentos, descobrir novos territórios e expandir a economia.

Diante da sistematização de novos conhecimentos, a descrição dos lugares deu ensejo ao aparecimento da Geografia como ciência. A Geografia integrava diferentes e análogos saberes jungidos à "escrita da terra", quer mediante descrições verbais e escritas, quer por intermédio de figuras (desenhos e mapas). De acordo com Martinelli (2011, p. 7):

Quando se fala em mapas, imediatamente se faz associação à Geografia. É um aspecto eminentemente cultural. [...] fazer geografia consistia em fazer mapas. Isso ficou bem claro antes do final do século XIX, antes de a Geografia se estabelecer como discurso escolar.

Dentro deste contexto, entende-se que foi a partir do século XIX, em especial, que a Geografia e a Cartografia atingiram novas perspectivas de maior amplitude. Tal processo aconteceu em razão da estruturação dos trabalhos acadêmicos, do nascimento das universidades e das sociedades de caráter científico.

Em vista disso, os estudos concernentes ao turismo têm alcançado importância ímpar dentre as aplicações cartográficas. A atividade turística destaca-se no setor terciário, de prestação de serviços, desde meados do século XX e se projeta como considerável geradora de empregos, experimentando um processo de crescimento econômico e de transformações espaciais aceleradas.

O turismo revela e desvela as interações da prática social no espaço geográfico, a evidenciar suas múltiplas interfaces e a contribuir para o dinamismo desta relação no território. Considera-se, isto posto, que o turismo é igualmente relevante tema no estudo da Geografia e manifesta, cada vez mais, seu enfoque na conexão da organização do espaço, tendo este como seu elemento fundamental de consumo (CRUZ, 2003).

A utilização do tempo livre, quando associado ao lazer, pode apresentar como relevante maneira de aquisição do turismo. Esse uso passa a fazer parte integrante da chamada lógica de mercado, atividade que tem como objetivo vender o produto turístico como objeto aprazível e que vislumbra atender desejos do visitante, decorrentes, muitas vezes, da publicidade que se faz em torno do lugar. As diversas cartografias direcionadas para o turismo 
inserem-se neste mundo de encantamento como meios informativos que apontam, principalmente, a localização e descrição dos atrativos.

É preciso atentar, destarte, que a cartografia do turismo, ramo especializado da cartografia temática, auxilia na percepção e no entendimento da dinâmica do turismo existente no espaço. Os mapas possibilitam que a apresentação dos dados e fenômenos turísticos, sob a forma gráfica, torne-se importante documento que permite, aos turistas e gestores, uma visão geral do espaço geográfico, desde o processo de pesquisa, planejamento, marketing, avaliação e até a efetuação de um possível reordenamento territorial. O turismo, quando aportado na ciência da cartografia temática, indica algumas possibilidades suscetíveis de incrementar suas práticas sociais, econômicas e espaciais. Há a convicção de que o uso dos mapas na articulação dos diferentes fenômenos turísticos representados no espaço possibilita a compreensão da realidade e suas diversas conexões.

A atividade turística apresenta, ao longo do tempo, rápido crescimento e as consequências deste processo, quando não há um planejamento bem estruturado, são passíveis de acarretar sérios problemas estruturais humanos e de impactos ambientais desastrosos. Com esta posição estratégica, o planejamento necessita ter uma visão dos objetos em movimento, os quais podem ser concebidos por intermédio do conhecimento científico, que requer a adoção de uma metodologia capaz de facilitar a assimilação da complexidade das questões envolvidas. Neste sentido, a cartografia temática, mostrada como linguagem visual de representação gráfica de caráter monossêmico, corresponde, também, aos anseios e realizações de pesquisas voltadas para projetos e planos turísticos.

Torna-se plausível, igualmente, acrescentar que a experiência técnica e profissional em cartografia vivenciada pela autora desta dissertação, e, em grande parte, em ambientes relacionados ao turismo, sustentou o progresso deste trabalho. O interesse pelo tema abordado é uma realização que envolve os conhecimentos prévios adquiridos desde a infância do elegido objeto de estudo, o município de São Luiz do Paraitinga, localizado no Vale do Paraíba.

São Luiz do Paraitinga é uma estância turística, na qual prevalece o turismo de lazer. Por ser cidade tombada, muitos moradores, turistas e as pessoas de forma geral, associam, de imediato, o lugar com patrimônio cultural. Para a maioria, no entanto, este patrimônio cultural é formado apenas pelos bens materiais, constituídos pelas antigas edificações, em especial, as construídas à época da exploração da monocultura cafeeira e do período de circulação de tropas pela região e os bens imateriais, como as festas tradicionais. 
Diante disto, a maioria dos turistas permanece no lugar apenas um dia ou um final de semana, mesmo durante as épocas festivas e visitam tão só o centro histórico. É certo, não obstante, que o turismo no município vai muito além da área urbanizada. A extensão e as particularidades do território luiziense apontam potencialidades para a prática de atividades turísticas em espaços rurais e áreas naturais. Existem diversas fazendas históricas, campos naturais, rios encachoeirados e densa vegetação, oportunas para o aproveitamento do turismo alternativo, ainda pouco explorado na região.

Com a finalidade de colaborar com um consciente avanço das atividades turísticas no município, buscou-se discutir a concepção da cartografia temática que englobe a contribuição dos mapas no processo de transformar diversos dados em informações visuais e possibilitar a compreensão da veracidade do território luizense.

Diante deste contexto, afirma-se que o principal objetivo deste trabalho é salientar a relevância da cartografia temática nos desdobramentos da prática do turismo, em particular, usufruir das representações gráficas como notável contribuinte na fruição e no planejamento turístico do município de São Luiz do Paraitinga.

Ademais, específicos objetivos foram traçados e, por meio da agregação de diversos mapas analíticos, elaborou-se o mapa síntese das unidades espaciais delimitadas e identificadas por tipos de paisagens. Tais singularidades lucubraram possibilidades de detectar áreas com potencialidades turísticas, compreender a prática do turismo e especificar os usufrutos das atividades implantadas. Estes fatos subsidiaram uma sugestão de proposta preliminar de zoneamento e acredita-se que o complexo deste arcabouço possa contribuir, mesmo que parcialmente, para um planejamento direcionado ao turismo.

Para a abordagem definida neste trabalho, inicialmente, no capítulo 1, foram resgatados os referenciais teóricos sobre cartografia. Descreveu-se breve apanhado sobre a história da cartografia temática, sucedida com a preocupação em trabalhar os novos avanços na cartografia, beneficiada pela contribuição de sucessivos paradigmas na busca de reconhecimento como ciência. Dentre referidos paradigmas, destacou-se a Semiologia Gráfica, representada graficamente dentro de um sistema monossêmico pelas 'variáveis visuais'.

No capítulo 2, apresentou-se a prática do turismo como objeto de estudo da ciência geográfica, focando-se na dinamicidade social e econômica ocasionadas pelo consumo do espaço. Em seguida, optou-se pela abordagem de breves conceitos sobre o patrimônio cultural e o aproveitamento deste na prática das atividades turísticas. Com os olhos voltados ao 
acelerado crescimento do turismo, julgou-se relevante discutir sobre o planejamento, com o intuito de evitar impactos indesejados.

No encadeamento dessas ideias, no capítulo 3, envolveram-se a cartografia temática e os estudos do turismo. Destacou-se que a cartografia, por meio da representação gráfica, permite aos turistas e gestores, ampla visão do espaço geográfico em suas diversas expressões. Foi abordada, também, a relevância das novas tecnologias para os mapas turísticos e, por fim, destacaram-se metodologias versadas pela cartografia temática direcionada, de forma específica, para o planejamento do turismo.

No capítulo 4, o enfoque dado dirigiu-se às caracterizações do objeto de estudo deste trabalho. A relevância da história, aspectos demográficos, econômicos, infraestruturas e patrimônio cultural foram apanhados com o propósito de apurar a prática do turismo e seus diversos usos nas áreas urbanas, rurais e naturais de São Luiz do Paraitinga.

Concebeu-se, no capítulo 5, um conjunto de mapas temáticos analíticos com a finalidade de ampliar o entendimento de alguns fenômenos geográficos do território luizense. Destarte, o agrupamento de tais mapas forneceu as informações necessárias para a elaboração de uma cartografia de síntese, delimitada e identificada por tipos de paisagem, a qual serviu de orientação para proposta preliminar do zoneamento turístico. Aclara-se que os mapas exibidos neste capítulo foram confeccionados e aprimorados pela autora.

Por fim, diante das conclusivas considerações, apontaram-se os resultados alcançados e as possíveis possibilidades da aplicação deste estudo como aporte para a fruição e planejamento do turismo de São Luiz do Paraitinga. 


\section{Capítulo 1}

\section{CARTOGRAFIA TEMÁTICA}

\subsection{Breve apanhado sobre a evolução da Cartografia Temática}

Desde épocas bastante remotas, o homem utiliza-se da confecção de mapas como forma de comunicação, com o objetivo de relatar os conhecimentos sobre seu espaço de vivência. Era o começo de uma caminhada em direção ao que hoje se conhece por Cartografia.

Em uma conceituação bastante recente, atribuída pela Associação Cartográfica Internacional (ACI) ${ }^{1}$, a Cartografia é compreendida como:

[...] a habilidade ímpar para a criação e manipulação de representações visuais ou virtuais do espaço geográfico - mapas - para permitir a exploração, análise, compreensão e comunicação da informação sobre esse espaço.

Os mapas, junto a qualquer cultura, sempre foram, são e serão formas de saber socialmente construído. Como linguagem, os mapas conjugam-se com a prática histórica e revelam diferentes visões de mundo. Carregam, igualmente, um simbolismo que pode estar associado ao conteúdo neles representado (HARLEY, 1991).

A ciência cartográfica evoluiu de forma intensa e são muitos os episódios no transcorrer da história da sociedade humana que cooperaram para que isso acontecesse. Desde o mapa da cidade Çatal Höyük, da Turquia (6200 a.C.) e o gráfico de Bedolina (2500 a.C.), da Itália, até os mapas da era da informação, a cartografia desenvolveu-se de maneira cada vez mais efetiva. Para que esse resultado fosse primoroso, atingindo alto grau de aperfeiçoamento, valeu-se de incessantes e sólidas buscas de bases teóricas metodológicas (MARTINELLI, 2010).

Os mapas sempre foram auxiliares da Geografia, desde a Antiguidade Clássica, estabelecidas as concepções filosóficas dos gregos quando disseram que a Terra era esférica. Assim, conjectura-se que já começava a caminhada da cartografia à procura de uma afirmação científica.

O grande avanço da cartografia, para o pensamento ocidental, centralizou-se na Europa, nos séculos XIV e XVI, estando, tal avanço, relacionado com o Renascimento. Nessa

\footnotetext{
${ }^{1}$ Disponível em: <http://icaci.org/>. Acesso em 15 de agosto de 2013.
} 
época, começaram nascer as relações capitalistas, fato que intensificou o comércio entre o Ocidente e o Oriente. O desenrolar desses episódios exigiu o desenvolvimento da navegação e o ímpeto na necessidade de mapas (MARTINELLI, 2010).

No século XVII, a proposta primordial da cartografia firmou-se nos mapas topográficos de precisão e livres de quaisquer outros complementos. Já no século XVIII, a cartografia foi impulsionada por intermédio da criação de academias científicas, acontecimento que marcou o início da ciência cartográfica moderna.

No final do século XVIII e início do século XIX, entretanto, a procura de informações mais completas em diferentes áreas do saber estimulou a progressão e a sistematização de distintos ramos de estudo, concebidos a partir da divisão do trabalho científico, dentre os quais estava a Geografia. Esta nova situação proporcionou avanços também no campo da cartografia, dando margem ao surgimento de outra forma de elaboração de mapas, mais específica, emanada de um amadurecimento constante e gradativo, desde as primeiras colocações operadas no século XVII e XVIII. Desta forma, estabeleceu-se a Cartografia Temática, que viria responder pelo domínio dos mapas temáticos (MARTINELLI, 2010).

Neste ponto, Martinelli (2011, p. 27), amparado nas pesquisas de PALSKY (1996), afirma que "A cartografia temática não surge de forma espontânea; é historicamente sucessiva à visão topográfica do mundo, essencialmente analógica".

Essa colocação aponta que o desenvolvimento da Cartografia Temática não é um ramo distinto da representação topográfica. Na busca de mapas mais particularizados e com diversos temas, com o objetivo de alcançar a necessidade de uma demanda crescente, com novas probabilidades de se analisar o espaço geográfico, o desenvolvimento da Cartografia Temática acrescenta-se à representação topográfica.

A emancipação desta cartografia orientou a passagem da representação das propriedades apenas "vistas" (Cartografia Topográfica), para a representação das propriedades "conhecidas" dos fenômenos de cunho geográfico (Cartografia Temática). O código analógico foi substituído aos poucos por um código mais abstrato. Passou-se a representar mentalmente as categorias e não mais visualmente organizadas. Confirmou-se, assim, o mapa como expressão do raciocínio que seu autor empreendeu diante da realidade, apreendida a partir de um determinado ponto de vista: sua opção de entendimento de mundo. Deu-se a afirmação de uma postura metodológica na elaboração de uma cartografia temática para todas as áreas que a solicitariam (JOLY, 1990; MARTINELLI, 2011).

Para uma geografia, que nos seus primórdios preocupava-se mais com a descrição, sem qualquer designo explicativo, a cartografia tinha como encargo localizar objetos 
geográficos, além de qualificá-los. Esta cartografia tinha a finalidade de catalogar objetos diferenciados ou ordenados que compunham o conjunto daqueles produzidos pela sociedade de cada época e considerados apropriados à sua percepção de mundo.

Nos primeiros mapas, elaborados no século XVIII, tidos como temáticos, já são sentidas as primeiras pinceladas de transformação. Esse meio de comunicação começava a abandonar a ideia de arrolar e descrever de forma estafante todos os objetos que podiam ser relacionados à superfície terrestre, para dar ênfase a apenas um desses elementos, com vistas à maior compreensão e controle do espaço (MARTINELLI, 2010).

Segue-se, diante dessa atividade, o nascimento da cartografia temática, essencialmente positivista, adequada e pronta a atender as necessidades de outros ramos da ciência da época, em consonância com a respectiva postura metodológica dominante. A cartografia temática sempre teve a função de mapear o conhecimento empírico, a aparência dos fenômenos, tendo como ponto de partida observações e medidas concretas da realidade. Objetiva fornecer um instrumental apropriado à descrição, enumeração e classificação dos fatos.

A definição proposta por Salichtchev (1973), ainda que levadas em consideração as inovações fornecidas pela informática e pelos conceitos metodológicos da geografia, deve ser considerada, sem embargo de longevidade, embora possa parecer uma definição ultrapassada, presta-se para caracterizar a particularidade da cartografia temática.

A Cartografia é a ciência que retrata e investiga a distribuição espacial dos fenômenos naturais e sociais, suas relações e suas transformações ao longo do tempo, por meio de representações cartográficas - modelos icônicos que reproduzem este ou aquele aspecto da realidade de forma gráfica e generalizada (SALICHTCHEV, 1973; apud MARTINELLI, 2011, p. 28).

O conceito revela que a cartografia não tem instrumental suficiente capaz de representar e investigar conteúdos espaciais por meio dos citados modelos icônicos, sem antes se ter o conhecimento da essência dos fenômenos que serão representados e, tampouco pode desdenhar os ramos das ciências que os estudam.

Assim, a pluralidade dos mapas temáticos para um mesmo território pode participar, também, da abordagem geográfica. Para isso, não só se associam as interseções dos distintos conjuntos espaciais que cada tema desenha como, também, articulam-se os diferentes níveis escalares de representação combinadas com a ordem de grandeza da manifestação dos fenômenos considerados (LACOSTE, 2006).

Diante deste entendimento, oriundo das contemplações de Lacoste (2006, p. 232) obtém-se outra expressiva descrição para o produto da cartografia temática: 
Ele (mapa temático) reportaria certo número de conjuntos espaciais resultantes da classificação dos fenômenos que integram o objeto de determinado ramo específico, fruto da divisão do trabalho científico.

Afirma, no entanto, diante dessa concepção, que foi a partir do acúmulo dos conhecimentos científicos que métodos de representação ${ }^{2}$ específicos da cartografia temática tiveram significante evolução e acumularam consideráveis inovações.

Pela sua relevância, é digno realçar que, com a consolidação da cartografia temática, confirmada mormente no século XIX, deu-se um passo além dos esquemas clássicos de mapeamento, os quais tinham como preocupação principal os registros gerais topográficos, estabelecidos desde o Renascimento.

De acordo com Martinelli (2010, p.15):

No final do século XIX, a cartografia temática já munida de um consistente leque de métodos de representação extravasa uma restrita aplicação científica e técnica para tornar-se progressivamente um meio de educação e informação geral. Ela passa a ser utilizada nos atlas geográficos, nos livros e textos de geografia, e até mesmo na imprensa, engendrando uma verdadeira revolução cartográfica.

Como resultado do pensamento histórico da cartografia e da cartografia temática, grandes são as inovações que são sentidas até os dias de hoje. Diversos autores, em pleno século XX, expuseram novas e consistentes metodologias. Mais recentemente, pensamentos enveredaram-se, de modo mais específico, à trazida da ciência da computação, com o auxílio da informática, para as práticas cartográficas.

No limiar do século XXI, sob os sensíveis efeitos da revolução tecnológica a atuar em vários ramos das ciências, é visível o rumo que segue a cartografia temática no caminho de sua consolidação, de maneira bem consistente.

\subsection{A Cartografia na busca de reconhecimento como ciência}

A partir do incremento da demanda de mapas cartográficos de precisão e mapas específicos por parte dos diferentes ramos de estudo científicos, ressalta-se um acontecimento bastante relevante durante o século XX. Neste período, houve a preocupação em trabalhar os

\footnotetext{
${ }^{2}$ Os principais métodos de representação da Cartografia Temática são: Método Corocromático (1800-1820); Método coroplético (1826); Método dos pontos de contagem (1830); Método isarítmico (1843); Método dos fluxos (1845); Método das figuras geométricas proporcionais (1851); Método da distribuição regular de pontos de tamanhos crescentes (1967). Mais detalhes consultar: MARTINELLI, Marcello. Os passos da Sistematização da Cartografia Temática. In: Anais II Simpósio Internacional Caminhos Atuais da Cartografia. São Paulo, FFLCH-DG-USP, 2010, p. 965-990.
} 
novos avanços na cartografia e esta é extremamente beneficiada por meio da contribuição de sucessivos paradigmas, que também se propagaram no domínio da cartografia temática na busca de um status de ciência.

Em relação a tais paradigmas, contemplam-se, dentre outras variantes, cinco deles, todos de venerável acepção: Teoria Matemática da Comunicação, Semiologia, Coremática, Transformação Cartográfica e Visualização (MARTINELLI, 2011).

A primeira proposta conta com a teoria elaborada por Warren Weaver e Claude Shannon $^{3}$ (1949), estabelecida dentro de uma postura sistêmica ou funcionalista, denominada de Teoria Matemática da Comunicação. Este paradigma fez com que o mapa passasse a ser visto como um meio de comunicação cartográfica.

Tal teoria é compreendida pelo fluxograma (emissor $\rightarrow$ código $\rightarrow$ receptor). Neste caso, a comunicação torna-se um ato que depende de dois elementos polarizados: de um lado o transmissor e de outro o receptor. Entre eles aparece o canal de comunicação (o código), comum aos dois, que pode ser afetado por perdas causadas por interferências/ruídos.

Salichtchev (1977) faz uma importante revisão a esta colocação. Alerta que o método de comunicação cartográfica não poderia se prender meramente na Teoria Matemática da Comunicação. Esta teoria pondera apenas as perdas de informação em cada passo da comunicação e se preocupa fundamentalmente com a redução destes extravios. Para o autor supra citado, o processo de comunicação cartográfica deveria evidenciar os valores cognitivos dos mapas. Baseada nos estudos psicológicos, sua proposta tem como preocupação entender o comportamento do sujeito que faz o mapa. Do lado oposto, está a interpretação final de um mapa, que, assim, passa a ter acréscimos que dependem de conhecimentos acumulados do usuário. Como assevera o autor citado:

[...] a informação é objetiva, pois foi produzida sistematicamente através de um método científico, mas a interpretação pode sofrer influências por parte de cada especificidade dos leitores (SALICHTCHEV 1977, p. 19).

Tal colocação cognitiva da cartografia é representada pelo clássico Diagrama de Transmissão da Informação (figura 01), bastante destacado nos trabalhos de comunicação cartográfica.

\footnotetext{
${ }^{3}$ Esses autores apresentam um modelo linear de comunicação simples e eficiente na detecção e resolução dos problemas técnicos da comunicação. A teoria matemática da comunicação visava a precisão e a eficácia do fluxo informativo, procurando não se cingir apenas à área da engenharia, mas servir de referência a qualquer âmbito da comunicação.
} 


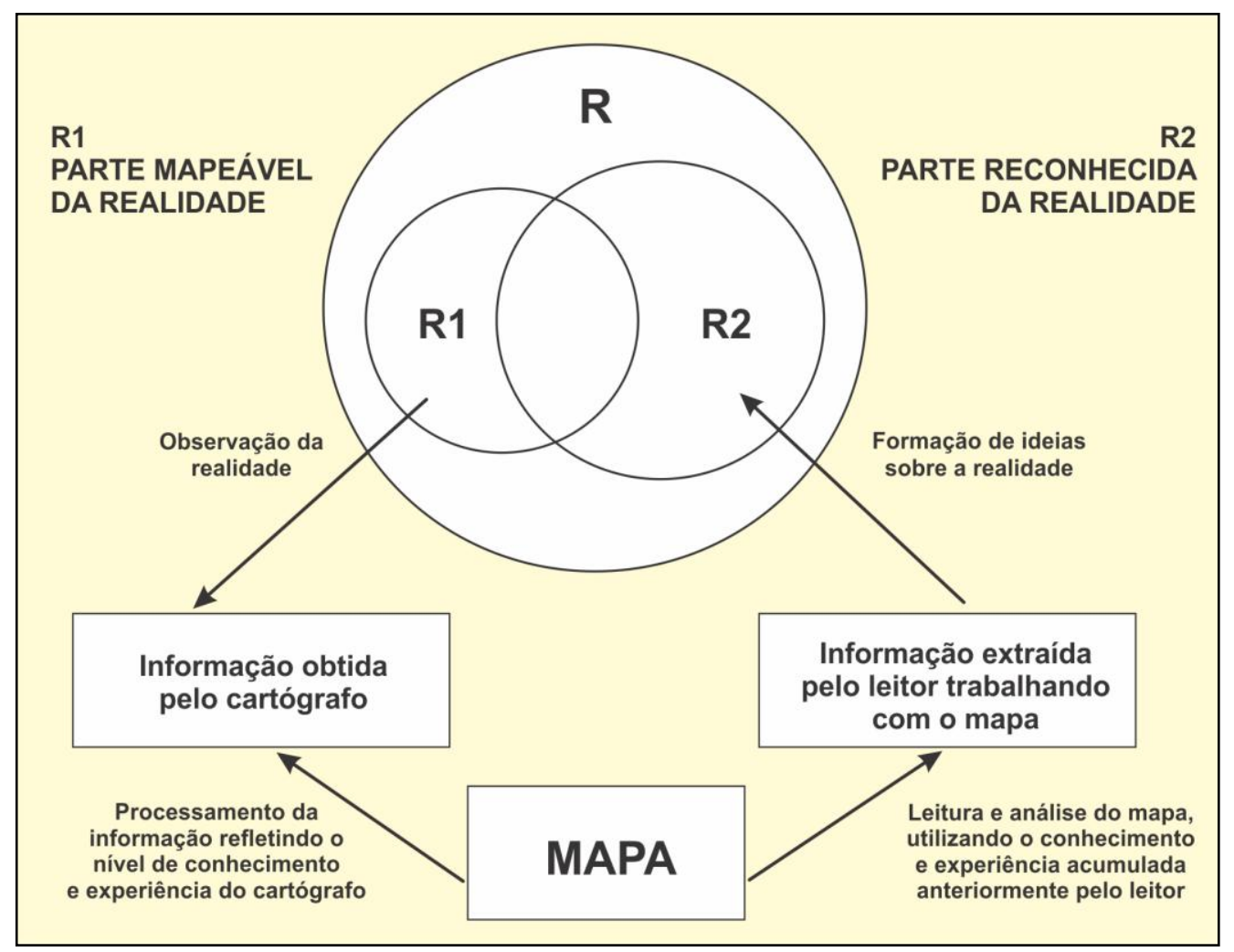

Figura 01 - Diagrama de Transmissão da Informação Cartográfica. Fonte: Salichtchev (1977, p.20)

De forma bastante distinta, Bertin, a partir da década de 1960, buscou os alicerces para sua conjectura uma cartografia em base estruturalista. Apoiou-se nas obras de Ferdinand de Saussure ${ }^{4}$, o criador da linguística, e tentou "encaixar" seus conhecimentos de cartografia dentro de uma linguagem.

Bertin lucubrou uma concepção com bases na Linguística, que, por sua vez, tem uma Semiologia, uma Teoria Geral dos Signos, cuja linha se considera indispensável para a postura tomada no desenvolvimento desta dissertação e será abordada com pormenores no subcapítulo seguinte.

Em sucintas palavras, a Teoria Geral dos Signos fundamentou a proposta para uma linguagem da cartografia que Bertin $(1973 ;$ 1977) denominou Representação gráfica (Graphique). Integraria o sistema semiológico monossêmico. A monossemia não estaria entre os signos e seus significados, mas sim entre os significados dos signos. Sua estrutura

\footnotetext{
${ }^{4}$ Linguista e filósofo suíço, cujas elaborações teóricas propiciaram o desenvolvimento da linguística enquanto ciência autônoma. Seu pensamento exerceu grande influência sobre o campo da teoria da literatura e dos estudos culturais. Saussure entendia a linguística como um ramo da ciência mais geral dos signos, que ele propôs fosse chamada de Semiologia.
} 
comportaria como variáveis visuais sensíveis ao olhar, as duas dimensões do plano e mais seis modulações que toda e qualquer mancha inscrita em tal plano pudesse assumir.

O terceiro paradigma foi proposto por Brunet, na década de 1980: é a Coremática. Esta é estabelecida diante da construção e combinação dos coremas, obtendo-se o "mapa modelo" de uma situação geográfica de forma bastante sintética. É preciso, nesta circunstância, atentar que é "o mapa em si que fala e não sua legenda". A linguagem do mapa estaria na forma, na estrutura, na dinâmica, no arranjo espacial e no significado das distribuições que evidencia (BRUNET, 1980 apud MARTINELLI, 2011).

O amplo desenvolvimento na área da informática possibilitou inúmeras iniciativas para novas representações. Trata-se das Transformações cartográficas, trabalhadas de forma bastante específica por Rimbert, desde as décadas de 1980 e 1990.

Estas transformações estariam fundamentadas na valorização dos padrões espaciais que os atributos ou as variáveis constroem, atentando mais para o aspecto estrutural, ao contrário de ficarem presas às constatações das distribuições geográficas.

Neste aspecto, a representação mais conhecida é a anamorfose, mais apropriadamente acomodada entre as transformações cartográficas espaciais. A partir de cálculos matemáticos, o mapa sofre deformações, nas quais a superfície é modulada de acordo com o maior ou menor valor da variável considerada (MARTINELLI, 2011). Tal representação favorece, na visualização, o tema centralizado, pois as áreas se dilatam (ou se contraem) de forma proporcional ao fenômeno representado.

Tendo em vista os avanços da cartografia nas últimas décadas, torna-se cada vez mais válido afirmar que não se pode falar de cartografia, nem de cartografia temática, sem se referir ao processo mediante o qual o mapa é criado e ao contexto social no qual se insere.

Frente aos recentes encaminhamentos da cartografia, quando ela se embateria com a evolução tecnológica e as propostas dos Sistemas de Informações Geográficas, emergiu a Visualização como um aceitável método de pesquisa científica. A visualização foi vista como "a ciência da representação visual de dados para lhes assegurar a comunicação ou a compreensão" (RHEINGANS, 1992 apud MARTINELLI, 2011). Ressalta-se que a visualização tem a ver com o conteúdo, portanto, deverá ser considerada no contexto sócio cultural no qual a informação cartográfica será empregada.

Diante das circunstâncias, releva-se que a ciência dos mapas atuais não pode ser vista fora do contexto da era da informação. Nela desponta como conceito central o de visualização cartográfica, a fim de se compreender a cartografia integrada à cognição e à análise (envolve o cérebro para reconhecer padrões e relações espaciais). Nessa conjuntura emerge, também, a 
comunicação visual e não visual (além dos visuais, incorpora elementos não visuais, como o som, por exemplo) e as novas tecnologias computacionais vinculadas às novas técnicas de multimídia interativa ou não, dinâmica ou não (LOCH, 2006; MARTINELLI, 2011).

Essa associação de entendimentos tem, hoje, ampla divulgação via internet e completa a base conceitual para a cartografia. Nesta ocasião, Taylor (2005, p.405) assimila um novo conceito para a cartografia, vista de um contexto mais atualizado:

Cartografia é a organização, apresentação, análise e comunicação da espacialidade georreferenciada sobre amplo leque de temas de interesse e uso para a sociedade em um formato interativo, dinâmico, multimídia, multissensorial e multidisciplinar.

Destarte, a cartografia granjeia importantes acréscimos respaldados na qualidade, admitindo interações entre diversos assuntos relevantes para a sociedade. Com a contribuição provinda de diversos especialistas, surge, então, uma cartografia mais dinâmica, flexível e multidimensional. A utilização dos dados espaciais causará transformações sólidas nesta ciência.

Diante deste entrecho, afirma-se que o desenvolvimento tecnológico contribuiu para o surgimento da cartografia digital, tornando-se uma área totalmente nova junto a toda estrutura de conhecimentos, já cristalizada da Cartografia. Os mapas passam a ser poderosos instrumentos de análise digital e visual capazes de apresentar graficamente, por visualização, o espaço geográfico, bem como permitir uma interface com o usuário. Isso acontece, de forma especial, ao se considerar todas as etapas do processo, desde o levantamento de dados até a fase final de mapeamento, visualização e utilização.

Conclui-se, pois, que em dias recentes, o usufruto das tecnologias na elaboração de mapas e, em especial os temáticos, tem sido fundamental. Não obstante, a cartografia é uma ciência e não pode, por isso, ficar alheia a estas inovações.

\subsection{Contribuições da Semiologia Gráfica para a Cartografia Temática}

Com base nos estudos da Linguística e sobre a Teoria Geral dos Signos, a Semiologia, a partir das quais Bertin propôs a Semiologia Gráfica para apoiar sua Representação gráfica, pode-se contemplar o processo de tratamento gráfico dos dados e o estudo das propriedades da percepção visual, objetivando a eficácia na comunicação entre o produto cartográfico e seu usuário (BERTIN, 1977). 
A Cartografia, dentro dos pressupostos levantados por Bertin, é realizada a partir da transcodificação da linguagem escrita para a linguagem gráfica, eliminando ao máximo o ruído na comunicação. Assim, ao se mostrar diferente da Teoria Matemática da Informação, esse enfoque busca trabalhar a Cartografia no âmbito da linguagem gráfica como sendo regida por leis universais, nas quais o signo gráfico não é arbitrário.

O autor apresenta a ideia de que o mapa é um tipo de representação gráfica que "constitui um dos sistemas de signos concebidos pela mente humana para armazenar, compreender e comunicar informações essenciais" (BERTIN, 1977, p. 6).

A representação gráfica é um domínio bastante específico. Ela se inclui no universo da comunicação visual, que, por sua vez, faz parte da comunicação social. Participa, portanto, do sistema de sinais que o homem construiu para se comunicar com os outros. Compõe uma linguagem gráfica bidimensional, atemporal destinada à vista. Tem supremacia sobre as demais, pois demanda apenas um instante de percepção (BERTIN, 1977; MARTINELLI, 2011).

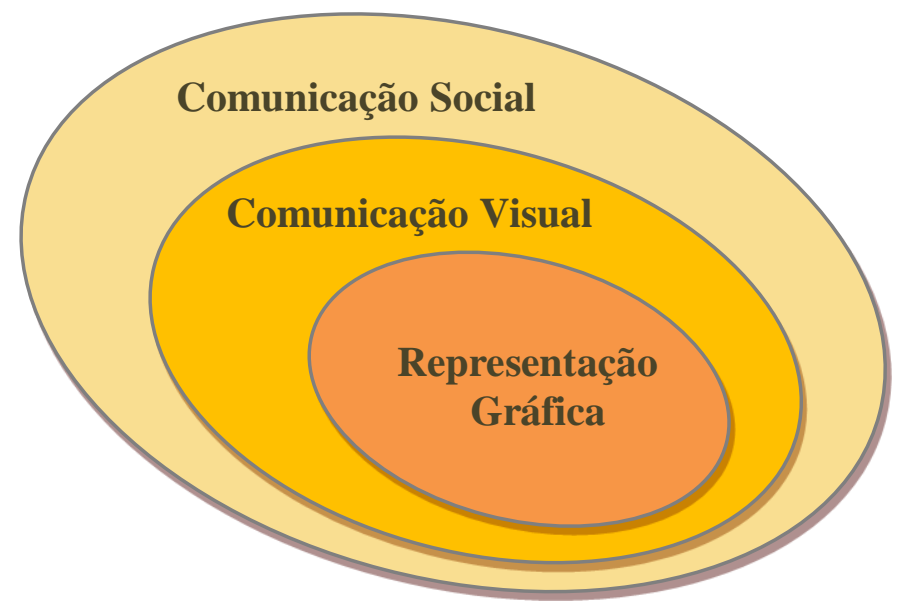

Figura 02 - Inserção da representação gráfica em campos mais amplos Fonte: Marcello Martinelli, 2010 5 .

A representação gráfica contempla o conjunto formado pelos mapas, diagramas e redes $^{6}$, que se expressam mediante uma imagem (captada em um lapso mínimo de percepção), que constitui um sistema semiológico monossêmico (significado único). Esta imagem é distinta das demais como a fotografia, a pintura, o desenho e o grafismo, com imagens, sejam

\footnotetext{
5 Apresentação em aula da disciplina "Representações Gráficas da Geografia: teoria e prática".

${ }^{6}$ Redes: representações gráficas específicas, como os organogramas, os dendrogramas, os fluxogramas e os cronogramas.
} 
figurativas ou abstratas, de características polissêmicas (significados múltiplos) (BERTIN, 1977; MARTINELLI, 2011).

A representação gráfica tem por objeto colocar em evidência as três relações fundamentais entre conceitos previamente definidos. Para tanto, ela transcreve tais relações por relações visuais de mesma natureza. Exclui, portanto, qualquer ambiguidade possível. É a definição de monossemia. [...] A comunicação polissêmica (caso do grafismo) tem por objeto definir um conjunto ou um conceito dentre uma infinidade possível. Ela é, portanto, sempre ambígua (BERTIN, 1977, p. 2).

$\mathrm{Na}$ forma de comunicação monossêmica, tanto o emissor como o receptor da mensagem colocam-se do mesmo lado do processo comunicativo como atores, diante das três relações fundamentais: diversidade/similaridade $[\neq]$, ordem $[\mathrm{O}]$ e proporcionalidade $[\mathrm{Q}]$. Saber coordenar tais orientações significa dominar a sintaxe desta linguagem.

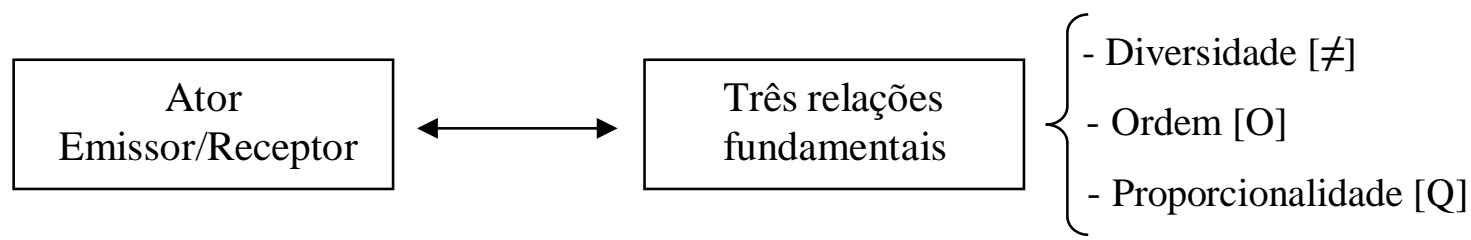

Figura 03 - Esquema de comunicação monossêmica

Fonte: MARTINELLI, 2011, p.31

Na mesma direção de Bertin, Martinelli (1991, p. 419) apresenta, de forma bastante concisa, os fundamentos semiológicos da Cartografia Temática:

A cartografia temática integra uma modalidade de representação gráfica, linguagem bidimensional de comunicação visual de caráter monossêmico. Sua especificidade reside no fato dela estar essencialmente vinculada ao âmago da relação entre os significados dos signos e não atrelada ao cerne da relação entre o significado e o significante dos signos, característica fundamental da linguagem polissêmica.

Na busca de uma sintaxe, ou seja, na procura do entendimento de como os signos devem se relacionar, como numa gramática, para estabelecer a comunicação junto à linguagem da representação gráfica, Bertin (1977) apresenta os componentes da imagem gráfica por meio de um quadro de 'variáveis visuais' (figura 04), capazes de transcrever graficamente os mesmos níveis de organização dos dados, a partir de seus diferentes níveis de percepção.

Fruto de propostas que vieram sendo elaboradas por vários estudiosos desde o século XVIII, com um amadurecimento maior no fim do século XIX, os mapas temáticos podem ser constituídos levando-se em conta vários métodos; cada um mais apropriado às características 
e à forma de manifestação (em pontos, em linhas, em áreas) dos fenômenos considerados em cada tema, seja na abordagem qualitativa, ordenada ou quantitativa.

O aspecto qualitativo $(\neq)$ responde à questão “o quê??", caracterizando relações de diversidade entre os conteúdos dos lugares, dos caminhos ou conjuntos espaciais. O aspecto ordenado $(\mathrm{O})$ responde à questão “em que ordem?”, caracterizando relações de ordem entre os conteúdos dos lugares, caminhos ou conjuntos espaciais. O aspecto quantitativo (Q) responde à questão “quanto?”, caracterizando relações de proporcionalidade entre os conteúdos dos lugares, caminhos ou conjuntos espaciais (MARTINELLI, 2011).

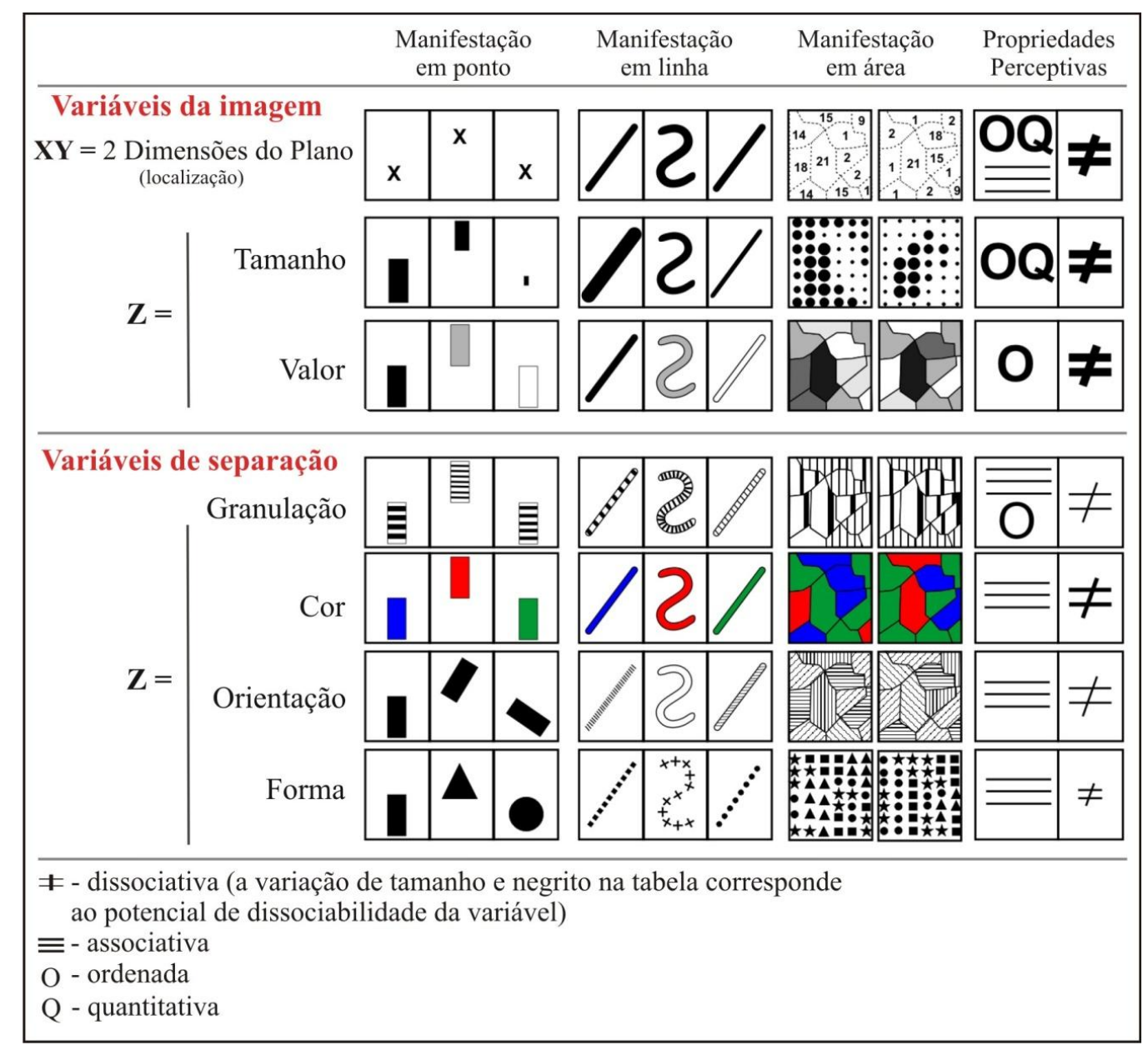

Figura 04 - As variáveis visuais de Jacques Bertin Fonte: Adaptado de BERTIN, 1977.

Ao analisar os componentes da imagem gráfica, Bertin (1977) defende a ideia de que a imagem, na representação gráfica, constrói-se, lê-se e se interpreta mediante dois componentes de localização, relacionados aos componentes geográficos, ou seja, as duas dimensões do plano (latitude Y e longitude X); um componente de qualificação, ordenação ou de proporcionalidade $(\mathrm{Z})$, representada sobre o plano através do emprego adequado de seis 
variáveis visuais (variáveis retinianas), cuja finalidade maior é a construção da imagem, na terceira dimensão visual $(Z)$, mediante manchas visuais. Duas dessas variáveis gozam do status de serem formadoras da imagem (tamanho e valor) e outras quatro variáveis visuais ditas de separação (granulação, cor, orientação e forma), apenas separam os elementos que compõem a imagem. Cada uma dessas variáveis pode, ainda, ser modulada para representar uma manifestação em ponto, linha ou área.

Por sua vez, cada variável, por conta de sua propriedade perceptiva, é mais adequada que outra para expressar determinado tipo de relação entre objetos/fatos/fenômenos. 'Tamanho' é a única variável que tem a capacidade de expressar relações de proporção (quantitativas). 'Valor' é a mais indicada para expressar relações de hierarquia (ordenadas). Esta capacidade de ordenação visual é explorada nas relações de ordem entre classes significativas de valores relativos numa representação coroplética. 'Granulação, cor, forma e orientação’ são usadas, em geral, para transcrever relações de diversidade.

A variável 'tamanho' modula variações da dimensão dos signos. 'Valor' apresenta variações na tonalidade da cor do signo, em uma gradação que vai do claro para o escuro (ou vice-versa). A variável 'cor' indica o comportamento do signo conforme a reflexão da luz visível, sendo expressa pela composição conjunta do matiz (que está associada a uma radiação espectral pura), saturação (grau de pureza de um matiz) ou valor (que é uma sequência escalonada na qual compõe uma ordem visual que segue do claro para o escuro ou vice-versa) (MARTINELLI, 2011). 'Granulação' apresenta o signo em texturas de linhas ou de pontos, de finas a grosseiras, tomando o cuidado de deixar, no conjunto, sempre a mesma proporção entre a quantidade de preto e de branco. 'Orientação' expressa a posição do signo (vertical, horizontal ou inclinado). E, por fim, a 'forma' modula as variações da forma do signo, assumindo diversas feições (geométricas ou não).

Ressalva-se para que as propriedades perceptivas possam ser representadas de forma eficiente, devem ser vinculadas a uma variável visual no mesmo nível de percepção, proporcionando ao leitor diversos agrupamentos, distribuições, associações ou isolamento dos signos. Dessa forma, evidenciam-se cinco relações fundamentais: dissociativa (objetos visivelmente identificados de forma variável, isto é, a visibilidade é variável); associativa (objetos facilmente identificados num mesmo conjunto, chegando a se confundir, isto é, a visibilidade é constante); seletiva (o olho consegue isolar os elementos); ordenada (ordem visual entre as categorias) e quantitativa (relação de proporção visual). 
Para se dominar a sintaxe da linguagem da representação gráfica, conforme Martinelli (2011), é preciso saber coordenar as relações entre os objetos, fatos e fenômenos, para, deste modo, obter-se uma transcrição gráfica de caráter universal, sem ambiguidades.

Frente a esta colocação, a aplicação de uma variável visual deve observar o nível de percepção para o qual ela é mais adequada. A cor, por exemplo, é uma das variáveis visuais mais empregadas em mapas, tanto em função de sua atratividade natural para os olhos humanos, como também pela sua faculdade de discriminar objetos e ocorrências, tanto em pontos como em linhas ou áreas. Para um melhor entendimento da organização entre as cores, dispõe-se do círculo das cores (figura 05). Tal construção considera uma série de pastilhas coloridas segundo a sucessão espectral das radiações visíveis.

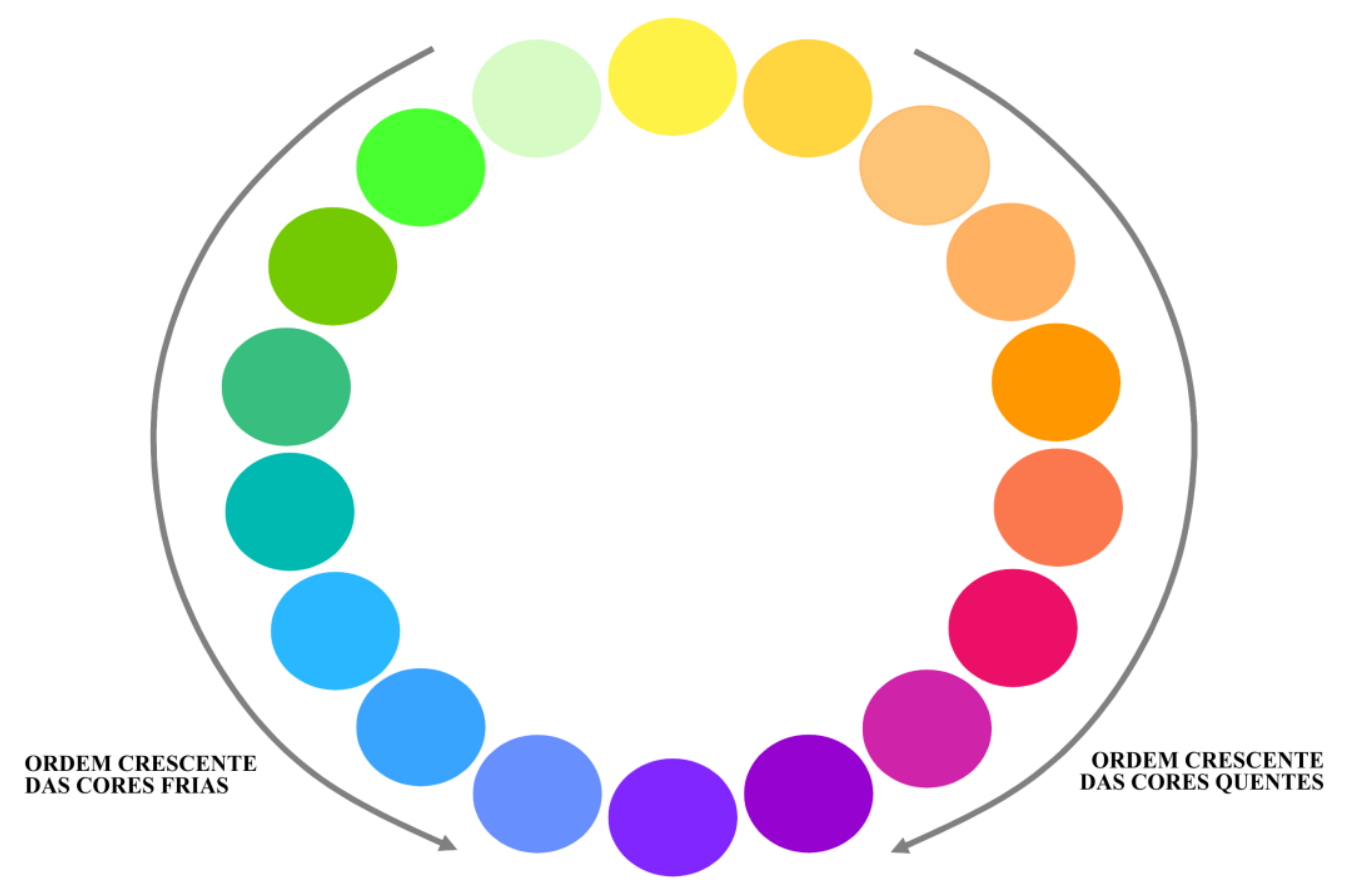

Figura 05 - Círculo das cores Fonte: Marcello Martinelli, $2010^{7}$.

As cores podem ser combinadas entre elas. Estas combinações manifestam-se de forma contrastante quando as cores são totalmente diversas entre si (contrapor as cores frias e quentes, por exemplo) ou de forma harmônica, quando as mesmas possuem uma similitude entre elas, de preferência uma sequência de cada vez (ou apenas cores quentes ou apenas cores frias), conforme mostra a figura 6. O mesmo resultado é obtido por meio da escala monocromática (variação de tonalidades de uma única cor).

\footnotetext{
${ }^{7}$ Apresentação em aula da disciplina "Representações Gráficas da Geografia: teoria e prática".
} 

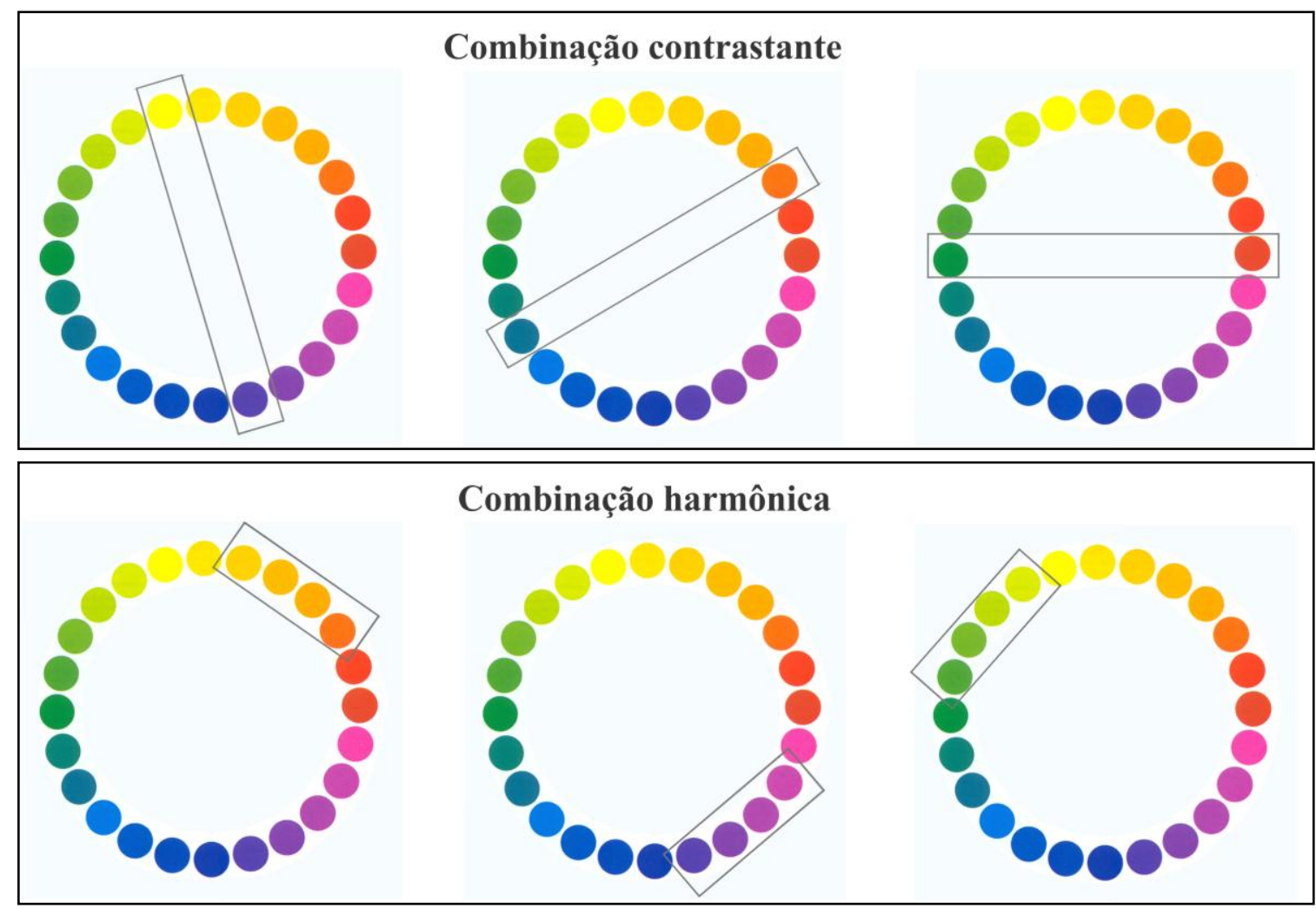

Figura 06 - Combinação de cores Fonte: Marcello Martinelli, $2010^{8}$.

O emprego da cor em construção cartográfica deve ser executado com extremo cuidado, pois essa variável tanto pode especificar somente a seletividade quanto a ordem entre objetos/fenômenos ou de seus valores, expressos numa sucessão ordenada de grupos de uma variável numérica em valores relativos.

É por intermédio das variáveis visuais que a cartografia temática contempla, como função, a construção e organização dos dados referentes à realidade a ser representada, com o fim de revelar a informação contida naqueles. Diante deste contexto, afirma-se que um mapa, quando elaborado segundo as regras da linguagem da representação gráfica, compõe uma imagem que exprime um pensamento, uma busca pela comunicação, um informe por intermédio de signos e o transcrito das variadas relações entre os dados referentes à realidade. Estes devem ter a garantia de uma interpretação correta, facilitada pela inserção da legenda.

Entende-se por legenda o componente do mapa que mostra o desenho da figura de cada signo e seu significado, além de demonstrar o raciocínio empregado pelo autor na elaboração do mapa. Ao se produzir um mapa, é propício, além da legenda, atentar para algumas características e demais componentes imprescindíveis para se realizar um bom trabalho. Os mapas devem ter: título (O quê? Onde? Quando?), orientação, em geral dada pelo

\footnotetext{
${ }^{8}$ Apresentação em aula da disciplina "Representações Gráficas da Geografia: teoria e prática".
} 
norte geográfico, referências de localização da área em coordenadas geográficas, escala gráfica e/ou numérica, projeção, fonte e ano de realização do mapa (JOLY, 1990).

Isto posto, os mapas temáticos são capazes de evidenciar algo mais do que apenas a posição do lugar, isto é, vão além de capacitar a representação somente para responder a questão “onde?”. Eles podem dizer muita coisa sobre os lugares, caracterizando-os. Adentrase, assim, no domínio da cartografia temática. Mapas deste tipo representam um ou mais temas que ocorrem em um determinado espaço, como os mapas ambientais, de aptidões agrícolas, geomorfológicos, turísticos e outros.

Dessa forma, para se elaborar os mapas temáticos necessita-se delimitar parte da realidade a ser problematizada pelo pesquisador interessado na realização da representação, com vistas a estabelecer diretrizes que orientem a busca de respostas às questões a ela colocadas. Depois de prontos, os mapas podem propiciar, em termos de apreensão, ou uma leitura em nível elementar ou uma visão de conjunto.

De maneira bastante sucinta e coesa, conclui-se pelas palavras de Martinelli (2011, p.41):

\begin{abstract}
Os mapas temáticos têm a possibilidade de serem construídos levando-se em conta vários métodos; cada um mais apropriado às características e à forma de manifestação (em pontos, linhas, em áreas) dos fenômenos considerados em cada tema nas abordagens qualitativa, ordenada ou quantitativa. Pode-se empreender também, combinadamente, uma apreciação sob o ponto de vista estático ou dinâmico. Deve-se salientar, ainda, que os fatos e fenômenos que compõem a realidade geográfica a ser representada em mapa permitem ser considerados dentro de um raciocínio de análise ou de síntese.
\end{abstract}

No ponto de vista das características estáticas representadas nos mapas temáticos, aspecto muito criticado pelos geógrafos da atualidade, Martinelli (2011) aponta que grande parte das produções ainda apresenta uma visão estática. Tais mapas são aqueles que registram um fato, uma situação, um fenômeno em dada ocasião e lugar, representam a realidade como se fosse imutável. Porém, deve-se considerar os mapas dinâmicos, que mostram a realidade essencialmente mutante. A prática mais comum para construir a ideia do dinamismo é a de confrontar diversas edições de um mesmo tipo de mapa em uma sequência temporal, no entanto, os mapas com diagramas (por meio de gráficos), mapas com variações relativas ou absolutas e os mapas de fluxos (rede articulada de vias de circulação) também são relevantes. Recentemente, se tem acrescentado às representações dinâmicas as contribuições trazidas pela animação cartográfica, interativa ou não. 
No que tange ao nível de raciocínio, há, de um lado, a cartografia analítica e, de outro, a cartografia de síntese. A cartografia analítica aborda os temas em mapas analíticos, atentando para seus elementos constitutivos, lugares, caminhos ou áreas determinadas por seus atributos ou variáveis. A cartografia de síntese contempla temas em mapas de síntese. Promove a fusão dos seus elementos constitutivos em "tipos", perfazendo agrupamentos de lugares, caminhos ou áreas unitárias de análise, caracterizadas por agrupamentos de atributos ou variáveis (MARTINELLI, 2011).

É preciso enfatizar, neste ínterim, que o mapa temático, quando elaborado e articulado diante das representações e os métodos cartográficos apropriados, é capaz de atender a demanda de diversos ramos científicos. Dentro do contexto desta dissertação, acolheu-se a cartografia temática como forma de comunicação, que tem atuado sobremaneira no desenvolvimento do turismo. Dada a importância do tema, outras análises neste tocante serão aferidas ao longo deste trabalho. 


\section{Capítulo 2}

\section{TURISMO}

\subsection{O fenômeno do Turismo e a Geografia}

Pela história, o termo turismo está fortemente associado ao conceito de lazer e, em consequência, às viagens espontâneas. Porém, no século $\mathrm{XX}$, novos segmentos a respeito do turismo surgiram, como o turismo de negócios, o turismo religioso, entre outros.

Dentre as muitas definições de turismo, atualmente, destaca-se a adotada pela Organização Mundial do Turismo (OMT). Tal acepção é muito importante porque vai nortear o trabalho realizado por organismos oficiais de turismo de todo o mundo. Para a OMT (2001), o turismo propicia o desenvolvimento de grandes intercâmbios sócio-culturais entre as nações, o que não poderia ser ignorado pelo controle e gestão de órgãos internacionais, como a ONU.

Turismo é uma atividade humana intencional que envolve deslocamento temporário de pessoas, onde o indivíduo permanece por mais de 24 horas e menos de 1 ano fora do local de sua residência, para a realização de qualquer atividade e satisfação de qualquer necessidade, sem intenção de lucro e se utiliza de meios de transporte, hospedagem e alimentação, dentre outros.

Nesse significado, turismo é uma modalidade de deslocamento espacial. Para ser considerado turismo portanto, segundo a definição da OMT, é preciso o uso de algum meio de transporte e um pernoite no local visitado, sem que haja lucro, sem remuneração direta e cuja permanência no local seja inferior a um ano. No conceito da OMT, há uma analogia entre viagem e turismo. Desta maneira, uma viagem para se participar de um congresso ou para tratamento de saúde iguala-se a viagens de turistas que passarão férias em um resort ou de um executivo, sempre a negócios. Esta definição sugere, desse modo, que viagem e turismo são sinônimos.

Dado que qualquer tipo de viagem, seja qual for o motivo é considerado turismo, pode haver uma séria interferência nas estatísticas do setor (CRUZ, 2003). Este fato fica mais evidente ao se observar as palavras de Cruz (2003, p.5) quando critica a definição genérica da OMT e afirma que:

[...] todo viajante é, para os organismos oficiais de turismo, um turista potencial, pois pode, tal como alguém que viaja por motivo de lazer, utilizarse total ou parcialmente das infra-estruturas turísticas presentes no destino. Não se pode negligenciar o fato, entretanto, de que, ao abarcar todo tipo de viagem como turística, a definição oficial de turismo conduz, entre outras coisas, à exacerbação das estatísticas. 
Após a Segunda Guerra Mundial, grandes variações conjunturais abalizaram o mundo. O fenômeno decorreu em face das transformações provocadas pelo conflito que repercutiu na coletividade das nações, gerando profundas reformulações estruturais. Esse artifício fez com que novas relações comerciais entre países se desenvolvessem. Isso permitiu a consolidação da abertura de mercado. Tal fato foi relevante para que o setor terciário surgisse na economia mundial, o qual abrange, sobremaneira, o comércio, finanças, saúde, educação, transporte, publicidade, cultura, comunicação, administração pública e privada, turismo, entre outros.

Por ser um serviço cujo comércio é internacional, o turismo receptivo tornou-se uma importante categoria do setor terciário. Os dados publicados pela $\mathrm{OMT}^{9}$ apontam que, nos dias atuais, o mercado turístico internacional movimenta altos valores e ampliam novos investimentos.

Em 2011, o total de rendimentos gerado pelo turismo mundial atingiu recorde, ultrapassou US\$ 1,030 bilhão quantia que representa um aumento de 3,9\% em relação ao ano anterior. Além disso, as chegadas de turistas aos locais escolhidos atingiram uma expressiva marca de 982 milhões, assinalou um crescimento de 4,6\%, confirmando, assim, uma forte relação entre os dois indicadores.

O alcance do turismo, no âmbito nacional, está, de perto, vinculado às competências e às atividades desempenhadas pelo Ministério do Turismo (MTur). Este foi criado no ano 2003, e procura promover o país como destino turístico, nacional e internacionalmente, fazendo uso por intermédio de grandes investimentos.

Ainda segundo dados fornecidos pela OMT, o total de turistas internacionais que desembarcaram no Brasil, em 2011, alcançaram 5.433.354 passageiros, um aumento de 3,85\% em relação a 2010. A receita cambial turística no país em 2011 somou US\$ 6,6 bilhões, uma variação positiva de 14,96\% em relação aos US\$ 5,7 bilhões auferidos em 2010 e de 64,22\% em relação a 2002, ano em que o Instituto Brasileiro de Turismo (Embratur) ${ }^{10}$ passou a cuidar com exclusividade da promoção turística do Brasil no exterior. Porém, esse trabalho, por hora incipiente, ainda não atingiu expressiva visibilidade internacional.

\footnotetext{
${ }^{9}$ Dados publicados pelo MTur no Anuário Estatístico de Turismo 2012 - Ano Base 2011, vol. 39 - p. 209. Disponível em: <www.dadosefatos.turismo.gov.br/dadosefatos/anuario>. Acesso em 1 de novembro de 2012.

10 A Embratur é a autarquia do Ministério do Turismo responsável pela execução da Política Nacional de Turismo no que diz respeito à promoção, marketing e apoio à comercialização dos destinos, serviços e produtos turísticos brasileiros no mercado internacional. Trabalha pela geração de desenvolvimento social e econômico para o país, por meio da ampliação do fluxo turístico internacional nos destinos nacionais. Disponível em: <www.turismo.gov.br/turismo/o_ministerio/embratur>. Acesso em 8 de novembro de 2012.
} 
Os gráficos a seguir apontam o crescimento da receita e o número de desembarques dos turistas internacionais no mundo e no Brasil, no período de 10 anos. Observa-se o declínio de valores no ano de 2009, resultado da crise financeira mundial no ano anterior. Contudo, nos últimos dois anos a economia global demonstra positiva recuperação, sendo o turismo um atual e promissor setor mercantil.

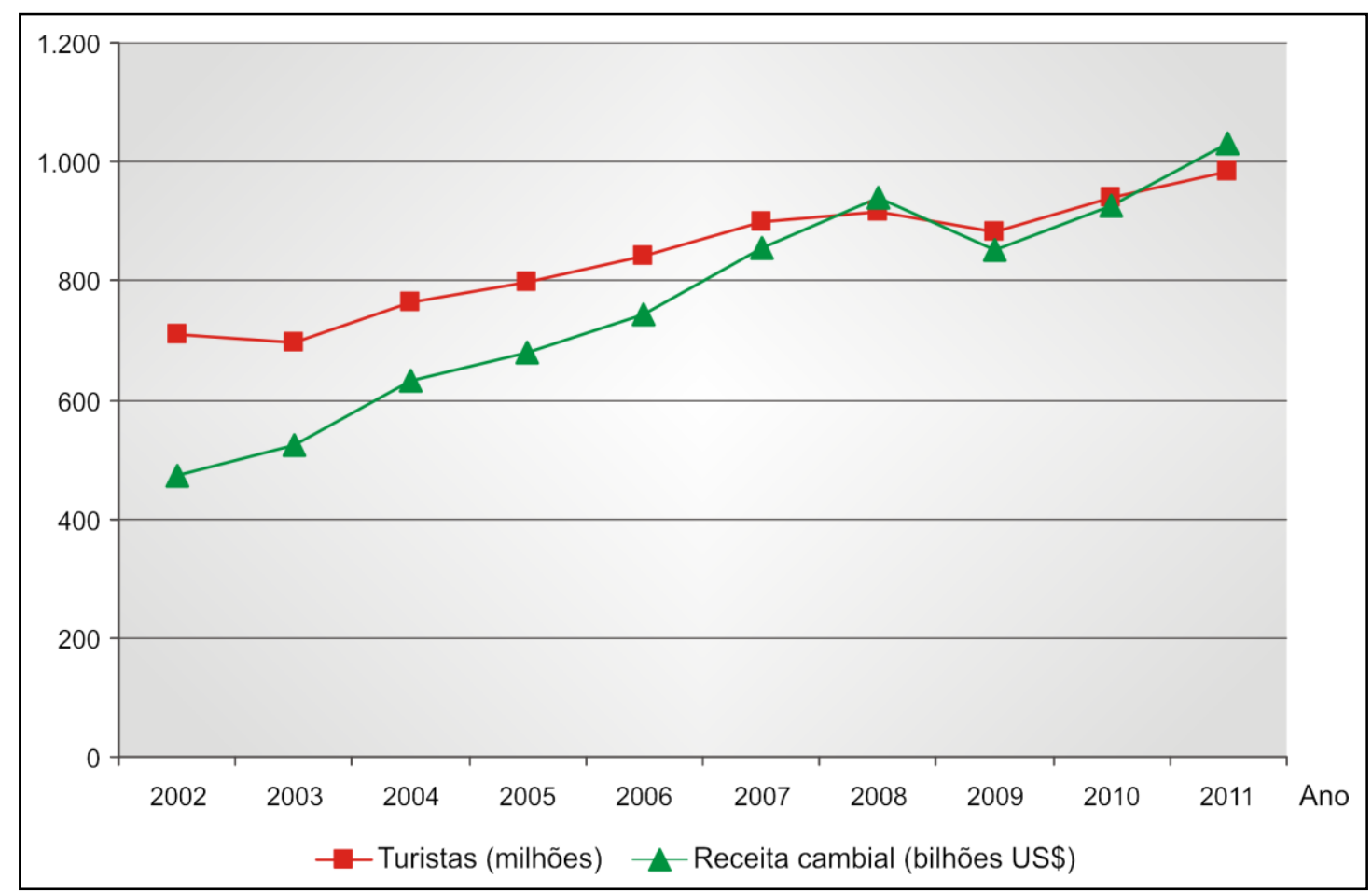

Gráfico 01 - Chegadas internacionais e receita cambial do turismo no mundo, 2002-2011. Fonte: Organização Mundial do Turismo - OMT

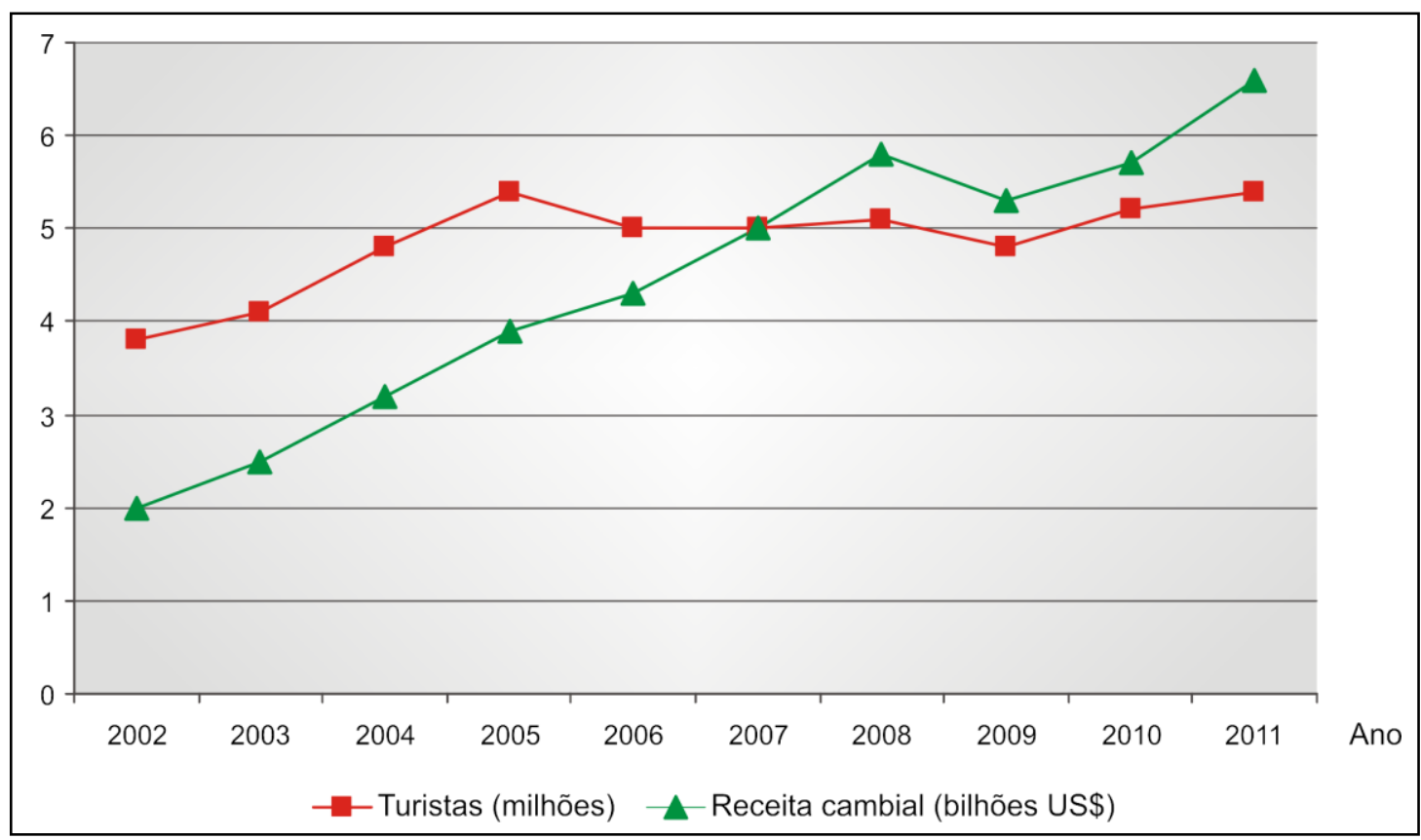

Gráfico 02 - Chegadas internacionais e receita cambial do turismo no Brasil, 2002-2011. Fonte: Organização Mundial do Turismo - OMT. 
O MTur também tem incentivado o mercado interno. O resultado desse apoio, conforme dados da Infraero ${ }^{11}$, evidencia o número de desembarques nacionais de passageiros que somou 79.244.256, correspondendo a uma variação de $15,8 \%$ em relação a 2010 . Esta movimentação dos aeroportos brasileiros em 2011 foi a maior já registrada desde o começo da série histórica, em 2000.

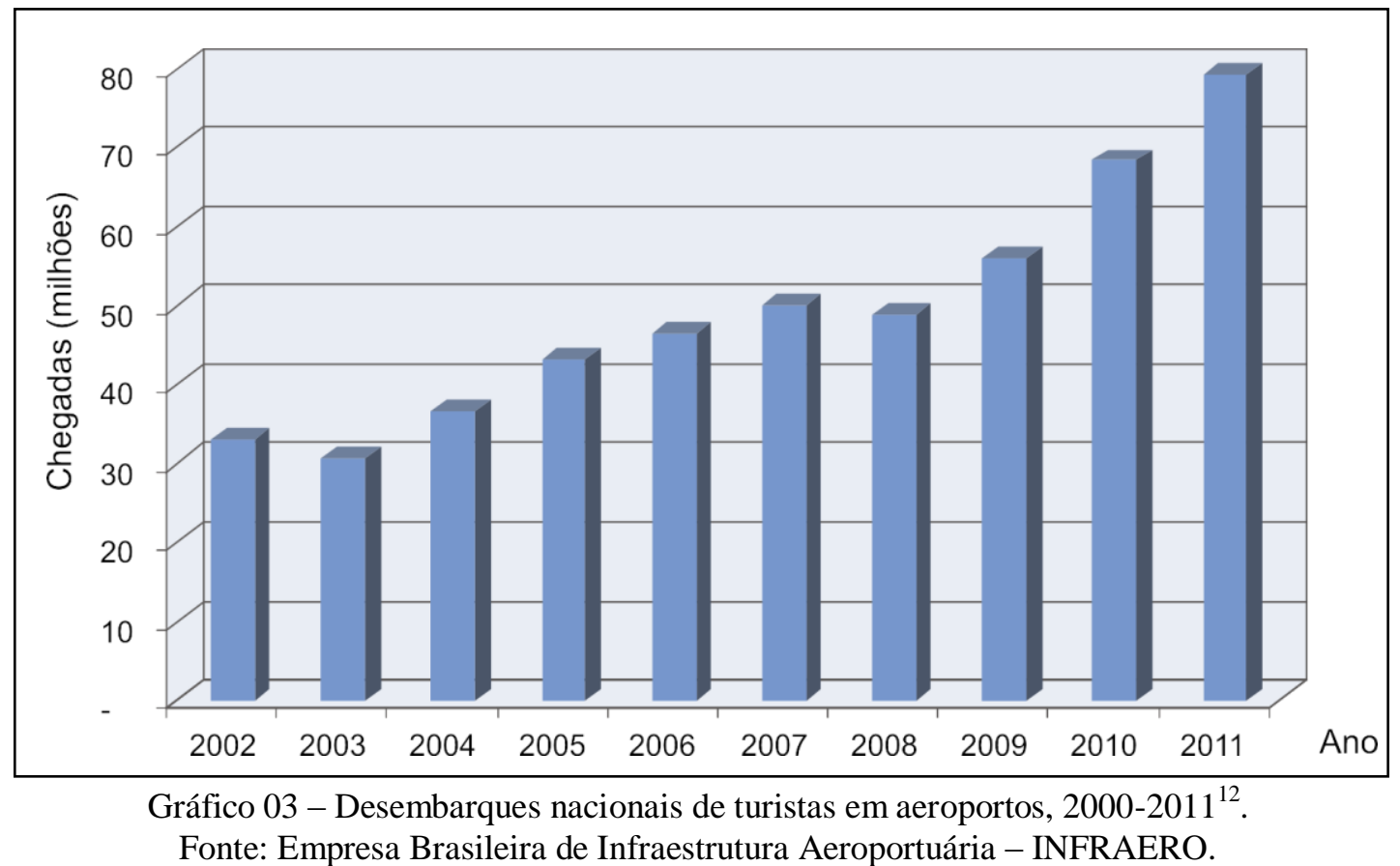

O MTur lembra que tudo isso acontece porque entre os brasileiros, hoje, o interesse pelo turismo passa a ser prioridade. Além disso, há mais facilidade ao crédito e constatou-se a evolução no salário médio dos trabalhadores.

Isto posto, ao se observar os dados estatísticos, confirma-se que o turismo, mais que uma atividade econômica, gera e distribui renda. O turismo também é visto como forma de inclusão de tarefas para se gerar e acumular capital. Em razão dessa interface, seu desenvolvimento requer, na sua execução, o desenvolvimento de consideráveis atividades em diversos campos financeiros e sociais.

O turismo constantemente está vinculado a determinado território. Mistura o natural e social, designado em seu todo como espaço turístico. O turismo, que é objeto de estudo da Geografia, prima pelo dinamismo e enseja consideráveis movimentações de pessoas o que resulta importante socialização, trocas de experiências, principalmente as culturais, e divide

\footnotetext{
${ }^{11}$ Dados publicados pelo MTur no Anuário Estatístico de Turismo 2012 - Ano Base 2011, vol. 39 - p. 170. Disponível em: <www.dadosefatos.turismo.gov.br/dadosefatos/anuario>. Acesso em $1^{\circ}$ de novembro de 2012.

${ }^{12}$ Nota: Os dados incluem desembarques de passageiros residentes e não residentes no Brasil.
} 
os espaços urbanos e naturais. Ou, ainda, "o turismo, entendemos, é, antes de mais nada, uma prática social, que envolve o deslocamento de pessoas pelo território e que no espaço geográfico seu principal objeto de consumo" (CRUZ, 2003, p.5).

Fica certo, no âmbito desta dissertação, o fortalecimento do turismo como lazer de forma mais intensa a partir do século XX. Hoje, o lazer se insere no domínio do tempo livre como atividade essencial na vida cotidiana.

Outrora uma prática das elites, vê-se, atualmente, a massa trabalhadora exercendo esta atividade. Nesse sentido Henriques (1996, p. 28) aponta que:

Foi a nova ordem social, econômica e cultural insaturada pela Revolução Industrial que possibilitou, em última análise, o desenvolvimento do turismo moderno [...] entre as transformações que a industrialização veio a provocar na vivência do mundo e nos estilos de vida, as mais profundas e abrangentes residiram na emergência de uma nova experiência de tempo e na redefinição da geografia do quotidiano.

Ao se refletir na teoria, o turismo assume, cada vez mais, sua abordagem na vinculação da organização do espaço. O turismo, como elemento sociocultural e econômico, é objeto de estudos geográficos quando se apresenta como uma atividade humana. Tal atividade procura abarcar o maior número de pessoas e, ao mesmo tempo, modificar espaços, congregando-os numa rede de serviços na forma de atrativos de lazer, para usufruto do tempo livre (RODRIGUES, 1997).

Portanto, em busca de satisfazer as necessidades de lazer instituídas pela sociedade moderna, é no âmbito do tempo livre que o turismo se estabelece. Tais necessidades são determinadas por uma sociedade que tem no consumo seu foco, e, ainda, com o apoio da mídia e novas tecnologias, trabalha o imaginário coletivo, o que os leva a valorizar os lugares turísticos, além de simplificar os fluxos de produtos e pessoas.

Com a globalização o mundo ficou pequeno. Diminuiu-se o tempo para se percorrer as distâncias, favoreceu-se a adaptação das fronteiras entre os países e o acesso às informações é realizado de forma rápida. Tudo isso acentua o interesse por localidades até então não conhecidas, dá origem a novas práticas de lazer e entretenimento, ativando, numa linha evolutiva, a facilidade de deslocamento.

De acordo com Rodrigues (1999, p.17):

O Turismo é, incontestavelmente, um fenômeno econômico, político, social e cultural dos mais expressivos das sociedades ditas pós-industriais. Movimenta em nível mundial, um enorme volume de pessoas e capital, inscrevendo-se materialmente de forma cada vez mais significativa ao criar e recriar espaços diversificados. 
Assim, diversos lugares (países, cidades, bairros) procuram meios de inclusão social e econômica, em um mundo competitivo e repleto de concorrências, no intuito de motivar o comércio de seus recursos e produtos de forma dinâmica e abundante. Nas palavras de Santos (2001, p. 46):

Neste mundo globalizado, a competitividade, o consumo, a dos espíritos constituem baluartes do presente das coisas. [...] Agora, a competitividade toma o lugar da competição. A concorrência atual não é mais a velha concorrência, sobretudo porque chega eliminando toda forma de compaixão.

Neste aspecto, aparece a discussão do quanto é importante o desenvolvimento do lugar e, ao mesmo tempo, estimular a prática de certas atividades econômicas capazes de ocasionar o desenvolvimento pretendido. Representa, destarte, o turismo, a conquista de uma considerável parcela do espaço o qual se converte em mercadoria. E é justamente através do processo de consumo dos espaços pelo turismo, unido ao à melhoria econômica e à dinâmica social, que surgem os lugares turísticos (CARLOS, 1999).

O turismo é uma prática complexa e de muitos enfoques, na qual se relacionam fixos e fluxos, abarca uma ação coletiva, integra diversos mecanismos e tem seus rebatimentos nos diferentes campos da organização espacial.

Nas palavras de Santos (2008a, p. 111), a configuração espacial pode ser definida a partir de dois conjuntos distintos:

O espaço é formado por dois componentes que interagem continuamente: a) a configuração espacial, isto é, o conjunto de dados naturais, mais ou menos modificados pela ação consciente do homem, através dos sucessivos "sistemas de engenharia"; b) a dinâmica social ou conjunto de relações que definem uma sociedade em um dado momento.

Ainda, segundo aponta esse mesmo autor, o espaço geográfico:

[...] é formado por um conjunto indissociável, solidário e também contraditório, de sistemas de objetos e sistemas de ações, não considerados isoladamente, mas como quadro único no qual a história se dá. (...) Sistemas de objetos e sistemas de ações interagem. De um lado, os sistemas de objetos condicionam a forma como se dão as ações e, de outro lado, o sistema de ações leva à criação de objetos novos ou se realiza sobre objetos preexistentes. É assim que o espaço encontra a sua dinâmica e se transforma (SANTOS, 2008b, p. 63).

Diante de tais reflexões, concorda-se com o autor que o espaço deve ser analisado como um conjunto indissociável do qual participam, de um lado, certos arranjos de objetos geográficos, objetos naturais e objetos sociais e, do outro, a vida que os preenchem e os animam, isto é, a sociedade em movimento. 
É nesse âmbito de mutação e de produção do espaço por meio da atividade turística que a Geografia se coloca. Preocupa-se, a Geografia do Turismo, com os aspectos sociais e espaciais do turismo e seus desenvolvimentos, ou então, "a geografia do turismo é uma expressão que se refere à dimensão socioespacial da prática social do turismo [...]" (CRUZ, 2003, p. V).

Ao se discorrer sobre o espaço, obrigatoriamente fala-se nos critérios geográficos, nos conceitos e informações de muitos elementos da realidade. Os elementos do relevo, da vegetação, do clima, do uso da terra e cobertura do solo, das relações humanas, com presença concreta da sociedade encontram-se entre eles, além da maneira dinâmica como se desenvolve a economia. Tais qualidades ou variáveis tornam-se artefatos atrativos ao turismo, que admitem e instigam as suas variadas práticas.

A assimilação do espaço pelo turismo, dentro deste conjunto, resulta na colocação de novos elementos e valores no território. Este passa ser (re)ordenado através de outra lógica de organização, capaz de converter-se em novas formações espaciais, ou seja, atividade turística que ocasiona, em certos elementos implantados no espaço, mudanças e transformações, de forma específica, nas paisagens.

Desde modo, concorda-se com Yázigi (2003, p.92) quando o autor atesta que "a paisagem, indisvinculável da ideia de espaço, é constantemente refeita de acordo com os padrões locais de produção, da sociedade, cultura, fatores geográficos e tem importante papel no direcionamento turístico".

\subsubsection{Conceitos de paisagem e sua aplicação nos estudos do Turismo}

O conceito de paisagem é polissêmico e pressupõe uma reflexão que permite diversas formas de abordagens. De forma sucinta, apoia-se no raciocínio de Santos (2008b, p.103) ao afirmar que "a paisagem é um conjunto de formas que, num dado momento, exprime as heranças que representam as sucessivas relações localizadas entre homem e natureza. $\mathrm{O}$ espaço são as formas mais a vida que as anima".

As mudanças morfológicas da paisagem não são prejudiciais e não podem ser consideradas fora das práticas sociais. A produção de um novo contexto material transforma a forma/paisagem e insere novas funções, valores e objetos. Esses objetos, formas dotadas de conteúdo, permeadas pelas ações e contextualizadas por um sistema de valores, são repletos de significados e intencionalidade. $\mathrm{O}$ conceito de intencionalidade constitui um estreito 
relacionamento com a dinâmica entre ação e objeto, evidenciando que os termos espaço e paisagem são inseparáveis.

Cruz (2002, p. 108) realça o caráter dinâmico atribuído a paisagem ao proferir a seguinte afirmação:

Ao refletir os espaços, as paisagens revelam (ainda que não de forma completamente explícita) sua dinamicidade. Se o espaço é dinâmico porque construído socialmente, também os são as paisagens, tanto em função dessa dinâmica social como em decorrência de uma dinâmica natural.

Diante disso, salienta Santos (2008b, p.107) que "a paisagem é história congelada, mas participa da história viva. São suas formas que realizam, no espaço, as funções sociais". Em suma, considera-se que paisagem e espaço não são sinônimos. Ambos se complementam e se opõem.

Alexander Von Humboldt, no século XIX, diante de sua visão naturalista, salientava que a paisagem deveria ser analisada pelo agrupamento fisionômico e natural da vegetação (MORAES, 2003). Apesar da relevância da pesquisa, nesta época, a Geografia ainda não abordava o caráter dinâmico da paisagem. Pelo contrário, estudava-a de forma analítica e fragmentada "guardava a noção de unidade natural, porém de caráter fisionômico, estético, sem história" (MARTINELLI; PEDROTTI, 2001, p. 40).

No século seguinte, no entanto, os estudos da paisagem foram realizados de forma mais concreta. A partir daí, apoiam-se em uma proposta baseada na concepção sistêmica. Amparando-se nessa nova compreensão, a paisagem passou a constituir-se uma integração entre o natural e o social, em uma escala tempo/espaço a qual permite que a mesma seja classificada em tipos, em razão da sua dinâmica e dos diferentes estágios de sua evolução (MARTINELLI; PEDROTTI, 2001).

Já nos estudos de Carl Sauer (1998), com base no pensamento positivista, a paisagem relaciona-se a uma visão de conjunto sobre uma área definida, diante formas naturais e culturais agregadas pela sua morfologia, destacando-se as análises estruturais e funcionais. De acordo com o autor:

A paisagem tem uma identidade que é baseada na constituição reconhecível, limites e relações genéricas com outras paisagens. Sua estrutura e função são determinadas por formas integrantes e dependentes. A paisagem é considerada, portanto, em um certo sentido, como tendo uma qualidade orgânica (SAUER, 1998, p.23).

Retornando-se nos pareceres de Santos (2008b), a paisagem prima por suas características visuais, pelo seu estilo dinâmico e por suas peculiaridades às mudanças sociais, 
acolhendo formas do passado, do presente e as prováveis tendências ao futuro, funções, estruturas e processos distintos. Sua produção e modificação sucessivas juntam-se, fundamentalmente, a fatores sociais (interesses humanos), os quais produzem e reproduzem, em diferentes escalas espaciais e temporais, os contextos culturais e históricos da sociedade e do espaço.

Diante disso, concorda-se com Cruz (2002, p. 108), ao mencionar Barbosa, que a paisagem é um ente cultural. $\mathrm{O}$ autor pontifica que "[...] por tratar-se de um ente cultural, a paisagem é portadora de signos. Dimensão do visível, do real, e do imaginário presentificado no espaço geográfico".

Martinelli e Pedrotti (2001, p.41) acrescentam que a paisagem não tem existência própria e está vinculada ao sujeito que a apreende. Os autores ressaltam que:

Qualquer paisagem, por mais simples que seja, é sempre social e natural, subjetiva e objetiva, espacial e temporal, produção material e cultural, real e simbólica. Para sua completa apreensão, não basta a análise separada de seus elementos. É preciso compreender sua complexibilidade, que é dada pela forma, estrutura e funcionalidade.

As diferentes abordagens do conceito de paisagem encaminham-se na associação de um entendimento objetivo (científico) e subjetivo (artístico). Isso lhe adjudica uma característica integradora perante os objetos e ações do espaço em movimento. Adiciona-se, porém, a ideia de paisagem que carrega consigo natureza e sociedade, objetividade e simbolismo.

A paisagem também tem sua relevância proclamada em diversas interpelações no campo do turismo. Frente a tal conjectura, transforma-se em um aspecto de grande importância, que se torna necessária uma análise mais intensa de sua repercussão.

Castro (2002) destaca, ao tratar da relação paisagem e turismo, que a paisagem coberta de um poder simbólico pode ser elevada a um bem coletivo e, por este motivo, precisa ser considerada na dimensão das relações sociais como imagem. De acordo com Castro (2002, p. 123), "a paisagem vai, portanto, muito além do real que lhe é ofertado pela natureza, embora ela também a incorpore, resultando - e ao mesmo tempo fazendo parte - da cultura". O conteúdo simbólico da paisagem evocado nas imagens, dessa forma, traduz-se em recursos turísticos. Estes recursos vão além da mercantilização e atingem o imaginário social. Nesta conjuntura, o valor estético da paisagem, que motiva o turista, é o primordial interesse para o avanço do turismo.

Quando se trata de imagens voltadas ao turismo, Martinelli (2001b, p. 160-161) afirma que "toda imagem encerra uma mensagem que depende de sua composição e de nossa 
interpretação no sentido conotativo. [...] Carrega um valor metafórico na medida que realiza a transferência do concreto para o abstrato". Este imaginário, com forte dose de fantasia, exerce encanto e mistério, o que estimula a venda do espaço produzido para este fim.

As paisagens podem, ainda, motivar o turista na busca pelo desconhecido e o desejo de conhecer novas culturas, influenciando os visitantes na escolha do lugar turístico. Quando se trata de paisagem como motivação de destinos turísticos, Yázigi (2002, p. 23) afirma que:

Buscam-se lugares que se revelam pelas paisagens, daí a importância que elas têm de elo entre o estranho e o mundo a ser descoberto. [...] As culturas e o modo como elas criam paisagens diferentes despertam o desejo de conhecimento, da experiência vivida.

Além disso, este mesmo autor salienta que a paisagem "é muito mais que uma visão, é a epiderme de toda condição histórica, social, econômica, política e cultural na qual, para se poder intervir, é preciso ir além dos projetos descomprometidos com a realidade" (YÁZIGI, 2002, p. 9).

Ao caracterizar a paisagem como sendo o conjunto dos fatores naturais e construídos enquadrados nos contornos da organização social, evidencia-se que estes fatores são sempre arquitetados e avaliados conforme os parâmetros, necessidades, possibilidades e limitações da sociedade. Neste entendimento, as paisagens são compreendidas pelo seu cunho histórico, por meio da análise de sua formação natural e social contemporânea e de suas contínuas fisionomias anteriores, conduzidas ao longo do tempo. Concorda-se com PaesLuchiari (2005) quando atesta que as paisagens são transformadas em meios de consumo e produtos turísticos.

A valorização das paisagens constituídas por componentes históricos, como os bens patrimoniais, revela-se, neste ínterim, como objeto adequado ao turismo. Estes têm outorgado às paisagens urbanas e naturais um novo propósito, uma nova finalidade no campo exploratório do turismo. Atualmente, o patrimônio transformou-se em local coberto pelo marketing comercial, muitas vezes, sem compromisso algum com o passado, com o lugar e com as expressões culturais. Porém, Canclini apud Luchiari (2005, p.99) adverte que "a urbanização, a mercantilização, a indústria cultural e o turismo nem sempre são os inimigos do patrimônio". Eles refletem, levando-se em conta o dinamismo mostrado pelas paisagens e existente no espaço, os sinais do tempo que contextualizam a importância do patrimônio cultural como polo de atração à atividade econômica, amoldado pelo turismo. 


\subsection{Patrimônio Cultural: princípios e conceitos}

A introdução do subcapítulo em epígrafe nesta dissertação, embora não pertença essencialmente ao cerne do discutido, é relevante, sobretudo, porque quando há referência a São Luiz do Paraitinga, de pronto avulta seu patrimônio cultural. Apesar de ser lembrado, em especial, pelo seu patrimônio cultural urbano, o município é bastante rico nos seus aspectos de turismo rural e de natureza.

Questões referentes ao patrimônio cultural articulam alguns saberes acadêmicos, que se colocam na interconexão entre a Arquitetura, o Urbanismo, a História e a Antropologia, estas já consagradas. Torna-se necessário salientar, no entanto, a importante contribuição que a Geografia pode conferir a esse tema.

As primeiras ações voltadas à preservação do patrimônio aconteceram na Inglaterra, quando um grupo de ilustrados começou colecionar objetos antigos. Partindo dessa premissa, iniciou-se um processo de valorização do passado através de peças as quais foram testemunhas da história nacional. Mas, é com a Revolução Francesa que o Estado assume oficialmente a função de resguardar os elementos os quais foram testemunhas do passado, de forma específica os bens desapropriados do clero e da monarquia, e que passaram a ser protegidos pelo Estado francês (CHOAY, 2000).

As políticas públicas de preservação da cultura no Brasil elegeram a arquitetura como foco de suas ações. Tal escolha teve a influência do modelo patrimonial instituído nesse contexto francês, sobretudo no que faz menção às políticas centralizadoras, ao sistema de organização dos órgãos públicos e pelas discussões centradas nas questões da identidade nacional.

No Brasil, a primeira alusão à proteção de bens culturais feita pelo Estado deu-se pela Constituição de 1934, quando se dispôs que "cabe à União e aos Estados proteger as belezas naturais e os monumentos de valor histórico e artístico [...]” (BRASIL, 1934), ou seja, tem-se a consagração do patrimônio histórico e artístico como um princípio constitucional.

No entanto, a primeira proposta de lei ordinária no sentido de garantir a salvaguarda do patrimônio cultural aconteceu mediante o projeto de lei criado por Mário de Andrade, em 1936. Pelo projeto, Mário de Andrade procurava abarcar uma noção de patrimônio no sentido amplo e global, no qual lugares, objetos, fazeres, saberes, manifestações eruditas e populares se colocavam como baluartes de uma memória nacional (RODRIGUES, 2011).

Oficialmente, porém, a preservação do patrimônio cultural brasileiro começou a ser envolvida pela esfera pública um ano antes. Em 1935 ocorreu a promoção da cidade mineira 
de Ouro Preto à categoria de Monumento Nacional. É importante considerar neste contexto, a criação, em 1937, do Instituto do Patrimônio Histórico e Artístico Nacional (IPHAN). Este foi instituído com a finalidade de regulamentar a proteção do patrimônio histórico e artístico nacional por meio do tombamento ${ }^{13}$.

As ações do IPHAN privilegiaram a proteção de monumentos valiosos, dando destaque às obras do Barroco, movimento artístico do século XVIII. Os edifícios dos períodos mais recentes, como os que se encontram no centro da cidade de São Paulo, edificados a partir do século XIX, foram relegados a segundo plano, fugiam à tradição brasileira. Formou-se, assim, um conjunto de bens que também representam a história, o passado da arquitetura e manifestação cultural brasileira (RODRIGUES, 2011).

No ano de 1968 foi criado o órgão de preservação do patrimônio do Estado de São Paulo, o Conselho de Defesa do Patrimônio Histórico, Arqueológico, Artístico e Turístico (CONDEPHAAT), que renovou o conceito de patrimônio e, deste modo, despontou uma possibilidade de contornar a precária situação do patrimônio em São Paulo. Os conselheiros escolheram proteger as construções filiadas ao neoclassicismo do auge da cafeicultura.

Em 1972, a Conferência Geral da ONU para a Educação, Ciência e Cultura firmou a Convenção sobre Proteção do Patrimônio Mundial Cultural e Natural. Entendia-se por patrimônio, neste documento, o resultado da produção material do homem: obras arquitetônicas, pinturas, esculturas, monumentos, sítios arqueológicos, entre outros. Essa diretriz levou à classificação de sítios do Patrimônio Cultural da Humanidade, que têm a chancela da UNESCO, recomendando a sua proteção (RODRIGUES, 2011).

O patrimônio cultural, sendo abalizado por determinado conjunto social como sua cultura própria, que sustenta sua identidade e o distingue de outros grupos, não compreende somente os bens materiais, como foi por bastante tempo considerado. Destarte, dentro do contexto de patrimônio cultural foram incluídos outros produtos como os valores étnicos, as artes que transcorrem no tempo, a dança, a literatura, o teatro e a música, ou melhor, considera que são inclusos os objetos do passado mais os costumes, celebrações, crenças, tradições, línguas, expressões, e elementos alheios que se incorporam a uma cultura viva.

\footnotetext{
${ }^{13} \mathrm{O}$ tombamento é um ato administrativo realizado pelo Poder Público, nos níveis federal, estadual ou municipal. Os tombamentos começam pelo pedido de abertura do processo por iniciativa de qualquer cidadão ou instituição pública. Tem como objetivo preservar bens de valor histórico, cultural, arquitetônico, ambiental e também de valor efetivo a população, impedindo sua destruição e/ou descaracterização. Pode ser aplicado aos bens móveis e imóveis, de interesse cultural ou ambiental. É o caso de fotografias, livros, mobiliários, utensílios, obras de arte, edifícios, ruas, praças, cidades, florestas, cascatas, etc. Somente é aplicado aos bens materiais de interesse para a preservação da memória coletiva. IPHAN. Disponível em:

$<$ http://portal.iphan.gov.br/portal/montarPaginaSecao.do?id=12576\&retorno=paginaIphan >. Acesso em $12 \mathrm{de}$ dezembro de 2012.
} 
A Constituição Federal do Brasil de 1988 (art. 216) define o patrimônio cultural brasileiro nos seguintes termos:

Constituem patrimônio cultural brasileiro os bens de natureza material, tomados individualmente ou em conjunto, portadores de referencias à identidade, à ação, à memória dos diferentes grupos formadores da sociedade brasileira, nos quais se incluem: I - as formas de expressão; II os modos de criar, fazer e viver; III - as criações científicas, artísticas e tecnológicas; IV - as obras, objetos, documentos, edificações e demais espaços destinados às manifestações artístico-culturais; V - os conjuntos urbanos e sítios de valor histórico, paisagístico, artístico, arqueológico, paleontológico, ecológico e científico.

A Conferência Intergovernamental sobre Políticas Culturais para o Desenvolvimento, em 1998, ampliou o conceito de patrimônio incluindo os aspectos imateriais herdados ou criados pela sociedade. Os bens imateriais foram institucionalizados no ano 2000, por meio do Programa Nacional do Patrimônio Imaterial (PNPI). Este programa viabiliza projetos de identificação, reconhecimento, salvaguarda e promoção de dimensão imaterial do patrimônio (RODRIGUES, 2011).

Em 2003, a UNESCO adotou a Convenção para a Salvaguarda do Patrimônio Cultural Imaterial. Essa convenção regula o tema do patrimônio cultural imaterial e, por conseguinte, contempla toda a herança cultural da humanidade. De acordo com o IPHAN (2012) ${ }^{14}$ :

O patrimônio cultural imaterial, que se transmite de geração em geração, é recriado constantemente pelas comunidades e os grupos em função do seu entorno, a sua interação com a natureza e a sua história, infundindo neles um sentimento de identidade e continuidade e contribuindo assim para a promoção e o respeito da diversidade cultural e a criatividade humana.

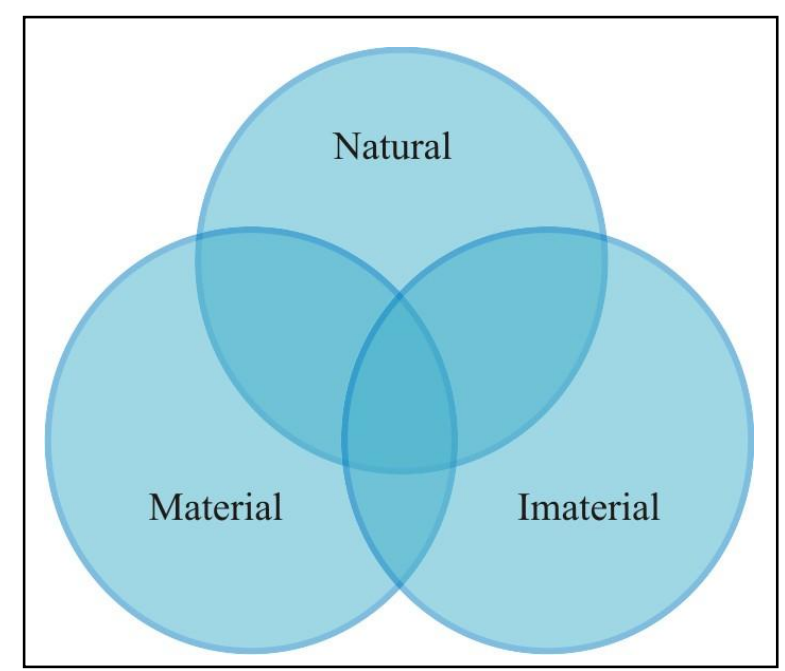

Figura 07 - Divisão geral do patrimônio cultural Fonte: Pereira, 2012.

\footnotetext{
${ }^{14}$ Disponível em: <http://portal.iphan.gov.br/portal/montarPaginaSecao.do?id=10852\&retorno=paginaIphan>. Acesso em: 12 de dezembro de 2012.
} 
Dessa forma, classifica-se o patrimônio cultural como um bem tangível e intangível. Bens tangíveis são aqueles que podem ser tocados, que têm existência física, equivalem ao patrimônio material como terrenos, edifícios, máquinas, instalações, e assim por diante. Aos bens intangíveis incorporam-se os elementos de caráter subjetivo, condizem com patrimônio imaterial (IPHAN, 2012; PEREIRA, 2012).

A "natureza" também recebe a concepção de patrimônio cultural, o que causa estranheza a várias pessoas. Mas, é explicável, dado que para Scifoni (2006) o patrimônio natural está engajado às práticas sociais e às lembranças, às tradições de um povo. E, sabe-se que o patrimônio natural abrolha de uma derivação do patrimônio cultural. Este se engaja à vida das pessoas e se legitima quando o grupo social discute e institui seu valor afetivo e social. Considera-se patrimônio natural lugares tombados e patrimonializados como sítios arqueológicos e ecológicos, parques, praças, etc. (PEREIRA, 2012).

Conforme Choay (2000), o valor cultural, o qual evoca uma suposta identidade local; o valor cognitivo, que evoca a cidadania; e o valor econômico vinculado ao turismo são alguns dos valores conferidos ao patrimônio cultural recém-inventado. Nesta mesma linha, Paes-Luchiari (2005, p.97) afirma que "a eleição de um patrimônio é sempre um processo socialmente seletivo. Depende do olhar que valoriza ou não os artefatos culturais, os bens imateriais ou os ecossistemas naturais".

No campo dos estudos geográficos, Paes-Luchiari (2005) acrescenta que o patrimônio cultural, o processo histórico e político de seleção de bens e paisagens são pensados em termos de produção do espaço. A refuncionalização ${ }^{15}$ do patrimônio acarreta em trazer novas funções às formas passadas. Nova configuração espacial e prováveis mudanças paisagísticas resultam de tal procedimento, quer em áreas naturais preservadas ou nos sítios históricos urbanos, lugar no qual a atividade turística é mais intensa.

\subsubsection{Turismo e Patrimônio Cultural}

A aproximação entre a indústria turística e o patrimônio destacou-se a partir de 1964. Como já citado, em 1968 , criou-se o CONDEPHAAT. Este foi bastante ligado a um processo de valorização do passado e da possibilidade do seu consumo pela atividade do turismo. Tal

\footnotetext{
15 “Adota-se o termo refuncionalização por considerá-lo mais adequado para uma abordagem geográfica, porém, é comum em trabalhos relacionados a patrimônios, utilizar-se o termo revitalização, renovação, requalificação, restauração, enobrecimento, entre outros" (PAES-LUCHIARI, 2005).
} 
fato teve como influenciador a Carta de Quito ${ }^{16}$, de 1967. Esta procurava relacionar, de modo direto, a preservação do "patrimônio monumental" como vetor de desenvolvimento através da atividade do turismo. Este procedimento, de alguma maneira, seguia em desacordo com as diretrizes do IPHAN, as quais valorizavam a arquitetura como um bem potencial distante de ser explorada economicamente (RODRIGUES, 2011).

Tal episódio acontecia, principalmente, devido às condições políticas do momento, um território nacional sob regime militar. Nessa época, foi promovida uma reforma administrativa que juntou as atividades oficiais do turismo às da cultura e dos esportes. Assim, foi criada a Secretaria de Cultura, Esporte e Turismo à qual ficaria subordinado o CONDEPHAAT.

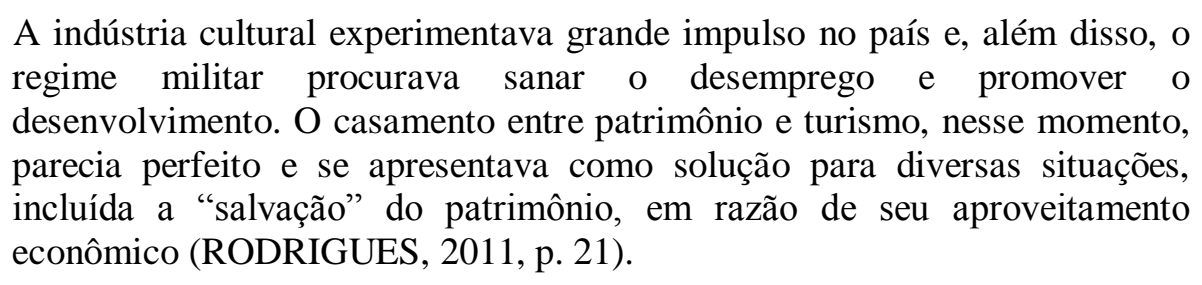

Segundo Santos (2006), foi no início da década de 1980 que o patrimônio foi visto como uma possibilidade do desenvolvimento turístico, fazendo com que as cidades sentissem o desejo de possuir e usufruir de seu patrimônio.

A partir de 1990, a redemocratização do país, ocorrida com a eleição direta para presidente da república (Fernando Collor de Mello - 1990/1992) e a adoção de novas políticas econômicas no governo de Fernando Henrique Cardoso (1995-2003), provocaram mudanças no patrimônio cultural, posto que este passou a ser definitivamente valorizado como bem comercializável, sendo transformado em respeitável objeto de consumo (SANTOS, 2006).

Há, hoje, o desafio de uma mudança cultural a qual mostra ser necessário mais eficiência e ampitude nas políticas e programas de conservação e criação do patrimônio cultural. O patrimônio cultural não é um objeto estático e imóvel. É, sim, um emaranhado de vivências e valores que precisam ter a sua dinâmica considerada. Isso é importante, para que, diante das inúmeras ingerências acarretadas pela modernidade, possa o patrimônio cultural, continuar a viver. Neste tocante, uma grande interferência, talvez a de maior relevância, vem da prática do turismo.

Essa premissa é confirmada pelos locais os quais tiveram seu valor acentuado para o uso do turismo, apontados como patrimônios culturais. Estes, instituídos e desenvolvidos pela

${ }^{16}$ O Departamento de Assuntos Culturais da Organização dos Estados Americanos (OEA) promoveu um encontro no Equador, do qual resultou um documento, assinado pelos países participantes, inclusive o Brasil: a Carta de Quito. 
sociedade, que, com o objetivo de resguardar os predicados materiais e imateriais de tempos passados, geram mudanças sócioespaciais.

Santos (2006, p. 39) pautado nas reflexões de Santos (2008a) considera que "os agentes responsáveis pela (re)produção do espaço criam e recriam formas espaciais. Estas, dentro da dinâmica social, vão adquirindo novas funções". Destarte, diante desta transformação permanente, com um imenso avanço da tecnologia, as perspectivas de reorganização do espaço cresceram. Por esta dinâmica, aos lugares foram introduzidos novos valores e começaram a exercer outras funções, não obstante por um período de tempo não muito longo.

Este processo, embasado no desenvolvimento do turismo, estimula o fluxo de pessoas, mercadorias, capitais e do valor imobiliário das edificações. Cifelli (2010, p.129) explicita de maneira bastante esclarecedora que:

Dentre as novas atribuições funcionais dos objetos antigos enquadram-se a criação de estabelecimentos comerciais, de serviços e equipamentos culturais e de lazer voltados para o atendimento dos interesses e necessidades da população flutuante. Dessa forma, os núcleos patrimoniais passam a congregar diversos meios de hospedagem, alimentação, lojas de souvenires, museus, galerias de arte, ateliês, antiquários e outros equipamentos que valorizem a atividade turística do lugar em detrimento das antigas formas de uso mistos - residencial, comercial e de serviços voltados para o atendimento da população local outrora predominante nestas áreas.

O patrimônio, ao ser direcionado ao turismo, adquire um novo sentido. Passa a ser visto como um produto e se destaca nas aspirações da sociedade e do mercado. Atualmente, a apropriação dos bens culturais adota o procedimento de transformar o patrimônio em produtos. Neste contexto, Paes-Luchiari (2005, p. 201), sustenta que:

[...] as singularidades do lugar expressas em seu patrimônio arquitetônico e imaterial (costumes, festas, ritos), reinventam a memória local, resgata o seu capital simbólico e cultural como espetáculo, e padroniza as suas formas tornando-as atrativas para a mercantilização do lugar que, no processo de acumulação flexível, é transformado em mercadoria turística.

Tal procedimento, que transforma o patrimônio em mercadoria turística, é criticado por muitos autores, uma vez que se propõe à fruição apenas visual dos lugares e descarta o sentido cultural do espaço e da população local. Ao adotar a postura de preservação estética, causa, na sociedade, diferentes implicações relativas ao patrimônio cultural e provoca um processo de alteração de valores. Isso faz com que o valor do patrimônio como sinônimo de identidade e memória se perca, pois a população é levada a acreditar que a atração turística é a função primordial dos bens culturais. 
O turismo e a 'patrimonialização' da cultura tem como objetivos uma finalidade educativa (compreensão da cultura dos grupos de acolhimento), além da parte econômica, bem como a social (SANTOS, 2006). Porém, em diferentes lugares, o rápido crescimento do turismo alicerçado no patrimônio cultural, associado à ausência ou omissão de um planejamento apropriado, acarretou uma ocupação espacial desorganizada.

Dado que se entende como patrimônio cultural um espaço no qual se institui o diálogo entre a sociedade atual e a do passado ao redor dos símbolos e das representações, o turismo não deve tomar posse deste patrimônio para satisfazer seu interesse próprio. Para isso, antes de tudo, precisa-se estabelecer uma vigorosa ligação entre a sociedade e o bem cultural, ao se examinar qual tipo de relação há entre o patrimônio e as pessoas que residem no local.

Considerando o espectro supra exposto, é de bom alvitre que a planificação da atividade turística seja dirigida no sentido de incrementar o potencial dessa relação. Isto significa que o planejamento turístico não pode levar em conta tão somente o contexto cenográfico do patrimônio cultural e a comercialização dos artefatos tradicionais. Estes, no momento da negociação, desvalorizam-se, perdendo suas qualidades materiais e representativas originais.

É, portanto, de suma importância para o eficiente desenvolvimento do turismo, um planejamento que leve em consideração consistentes alicerce cultural e social. Assim é porque é útil ao turismo que o visitante se interesse cada vez mais em conhecer os legados culturais dos sítios turísticos. Não obstante, deve haver uma preocupação maior para que o patrimõnio cultural não seja considerado apenas uma mercadoria negociável na lógica do mercado.

\subsection{Planejamento do Turismo}

O turismo apresentou, ao longo do tempo, um rápido crescimento o qual não foi acompanhado por inúmeras localidades. Tal desenvolvimento ocorreu de forma desordenada por não ser precedido de um planejamento apropriado. Desta maneira, como resultado, aconteceram inúmeros problemas estruturais humanos, financeiros e de impactos ambientais desastrosos. Consoante à questão, Duque e Mendes (2006, p. 20) afirmam que:

O planejamento turístico vem suprir esta necessidade de ordenamento da atividade, maximizando os retornos econômicos, sociais e ambientais do processo de desenvolvimento [...] dessa forma, o planejamento é essencial para garantir a sustentabilidade dos destinos turísticos. 
Ademais, aquelas áreas que vislumbram alcançar, manter ou conservar a valorização no mercado, deve utilizar de forma racional o espaço designado ao turismo.

Tende, destarte, a crescer a preocupação com o ordenamento do espaço aplicado no turismo, bem como o de controle dos resultados, especialmente para os destinos que aspiram expandir sua competitividade turística. A relevância do mercado conduz à exequibilidade das maneiras de como são usadas partes dos sítios dedicados ao desenvolvimento do turismo. Essa ação deve ser efetuada pela iniciativa privada, bem como mediante composição e associação com o poder público.

De acordo com Cruz (2003, p.14), “o mercado, por sua vez, representado pela iniciativa privada, pelos empreendedores do setor turístico, é hoje a principal fonte de turistificação dos lugares". No entanto, esta concorrência acarreta a necessidade de uma intervenção do planejamento territorial.

Portanto, é importante que se medite a respeito das ações de planejamento tendo como objetivo o futuro de um destino turístico. Segundo Hall (2001), o planejamento pode ser entendido como o processo de decisão, ou melhor, "planejar é o processo de preparar um conjunto de decisões a serem colocadas em prática no futuro". Cruz (2006, p.341-342) apoia nessa citação de Hall e afirma que:

Planejamento é algo que remete sempre a futuro, já que não se pode planejar o passado ou o presente. Por isso, planejar significa, sempre, projetar o futuro que se deseja. Mas para projetar o futuro é preciso olhar para o passado e identificar os erros que não se deseja voltar a cometer. É preciso também olhar para o presente, diagnosticar a realidade atual e, a partir disso, pensar sobre os cenários futuros que se almeja construir.

Considera-se o planejamento turístico bastante complexo. Este envolve diversas variáveis como a economia, sociedade, cultura, história e questões ambientais e, para tanto, existem diversos modelos de planos executáveis. Todavia, de acordo com Duque e Mendes (2006) tais modelos, mesmo que possuam enfoques específicos, adotam um caminho metodológico similar, estruturado nas seguintes etapas:

1. Definição de metas - apontam procedimentos iniciais os quais atribuirão diretrizes para o avanço do planejamento;

2. Diagnóstico - estudo exploratório que permitirá a identificação de fatos e tendências do turismo por meio de levantamentos de dados reais, como aspectos econômicos, sociais, ambientais, infraestruturas, entre outros, que serão analisadas com o intuito de indicar possíveis caminhos que o plano deverá seguir; 
3. Planos de ação - roteiros e soluções funcionais com o propósito de impulsionar a prática do turismo;

4. Execução - aplicar na prática os recursos abordados nas etapas anteriores; e

5. Avaliação - análise dos resultados, retoque das prováveis falhas, incorporação de novas informações e aperfeiçoamento.

Diante deste suporte, concorda-se que, o planejamento do turismo, quando corretamente executado, "pode minimizar impactos potencialmente negativos, maximizar retornos econômicos nos destinos e, dessa forma, estimular uma resposta mais positiva por parte da comunidade hospedeira em relação ao turismo no longo prazo" (HALL, 2001, p.29).

Ao se estudar o planejamento do turismo, defronta-se com uma plêiade de pessoas físicas e jurídicas que o rodeiam, muitas vezes com expectativas desiguais. Como pessoas físicas surgem a população local e os próprios turistas; como pessoas jurídicas, apresentam-se os agentes de mercado e os poderes. Ao contrário do que poderia parecer à primeira vista, nem sempre as perspectivas ou as esperanças são convergentes. É comum serem discrepantes. Torna-se necessário, por razões evidentes, harmonizar ou compor essas expectativas. A harmonização ou conciliação deve ser a bússola norteadora do governo na sua atividade política e de planejamento do turismo.

O turismo envolve, na sua realização, sujeitos sociais (população local, turistas, agentes de mercado, poderes públicos) com expectativas diferentes, não raras vezes divergentes. Conciliar esses interesses no ordenamento dos territórios pelo e para o turismo deve ser um paradigma orientador do planejamento governamental e de suas políticas públicas (CRUZ, 2005, p.41).

Esta preocupação faz com que o planejamento turístico esteja cada vez mais em evidência, trazendo consigo uma nova discussão sobre o papel que o Estado deve desempenhar no turismo e sobre os possíveis benefícios que a planificação ocasionará aos destinos.

O papel do Estado no turismo nem sempre foi estável e pode ser observado através do novo posicionamento da OMT. Enquanto nos anos 70 a IUOTO $^{17}$ (rebatizada como OMT em 1975) defendia o papel do Estado como centralizador da gestão turística, na segunda metade da década de 1990 a OMT passa a destacar a importância das parcerias entre os setores público e privado no turismo. Em seguida, no ano 2000, a OMT realiza e publica uma

\footnotetext{
17 A União Internacional de Organizações de Viagens (IUOTO) foi precursora da Organização Mundial do Turismo e argumentava que para fomentar o desenvolvimento do turismo era necessário centralizar os poderes responsáveis pela elaboração de políticas nas mãos do Estado para que ele pudesse tomar as medidas apropriadas a fim de criar uma estrutura adequada (IUOTO, 1974, apud HALL, 2001, p. 39).
} 
pesquisa com o objetivo de identificar as iniciativas de parceria entre os setores públicos e privados em todo o mundo, abrangendo 50 países, dentre os quais o Brasil (HALL, 2001).

Frente às circunstâncias, o planejamento e política turísticos, tanto no Brasil como no mundo, precisam ser coordenados e regulamentados. No entanto, governantes, de modo geral, sentem dificuldades em realizar um trabalho conjunto com as empresas privadas e membros da sociedade civil para se traçar normas de políticas públicas participativas. As políticas dos governos, de maneira especial no Brasil, apontam uma obsolescência na administração pública voltada ao setor turístico. O Estado ainda é importante, mas não exclusivo, no processo de planejamento do turismo.

A necessidade de se exigir um planejamento público em turismo é resultado das modificações constatadas no mercado turístico e de como o governo responde aos problemas de reestruturação econômica nos espaços urbanos e naturais. Perante um mercado turístico cada vez mais concorrente, alguns destinos procuram melhorar sua oferta local (atrativos, infraestrutura, equipamentos e serviços). Essa atitude tem como objetivo persuadir um maior número de visitantes, bem como expandir a "temporada turística". E, outras localidades, percebendo, também, as potencialidades econômicas do turismo, tentam atrair investimentos e, como consequência, a geração de empregos. Almejam, igualmente, o desenvolvimento desta atividade.

Hall (2001) argumenta que o planejamento turístico não é estático e que evolui de conforme com as exigências e interesses de vários grupos e com os valores que há na sociedade. A mesma autora defende que "a abordagem comunitária é somente um ponto de partida" para o planejamento turístico.

Neste processo, considera-se que haja o envolvimento da comunidade, dado que a relação entre esta e o turista é primordial. Além disso, a comunidade precisa saber dos impactos, tanto os negativos como os positivos que podem acontecer na localidade.

Perante o exposto, é prudente lembrar que o planejamento turístico deve ser um combinado de considerações políticas, econômicas, sociais e ambientais, com o objetivo de alcançar um desenvolvimento eficiente da atividade. É preciso, além disso, que se envolva intensamente, todos os atores nesse processo.

Quando um turismo é planejado e socialmente estruturado, quer na área urbana, quer na área natural ou espaços rurais, ao ser analisado através de abordagens geográficas, é capaz de acarretar benefícios às comunidades dos núcleos receptores, provocados pelos efeitos econômicos locais e regionais, apresentando as seguintes características (SIRGADO, 2003):

- Manutenção e incentivo dos atrativos turísticos; 
- Ativação do comércio local e dos serviços de alimentação e hospedagem;

- Promoção dos recursos por meio de qualificação da mão de obra local; e

- Oferecimento de originalidade e diversificação dos produtos turísticos.

No tocante ao planejamento voltado para bens patrimoniais usufruídos pelo turismo, Canclini apud Paes-Luchiari (2005, p. 103), salienta que há uma disputa econômica e política entre o Estado, o setor privado e a sociedade civil pelo patrimônio cultural. "As contradições no uso do patrimônio têm a forma que assume a interação entre estes setores em cada período". A preocupação principal de um planejamento turístico consciente deve ser harmonizar os diferentes usos e se preocupar com a população local, para que a mesma permaneça na localidade. Deve-se, também, observar as probabilidades dessas pessoas sobreviverem economicamente e terem acesso à moradia. Porém, não se pode deixar de lado os visitantes, nem o feitio público dos bens tombados (PAES-LUCHIARI, 2005).

Seria, então, o patrimônio cultural, visto através de uma situação integrada e ativa no quadro econômico-financeiro local, regional e/ou nacional, havendo um uso concreto. $\mathrm{O}$ turismo, tanto direta como indiretamente, depara-se incluso neste contexto. É necessário encontrar um meio termo que agrade às exigências dos grupos envolvidos, tais como pesquisadores e conservadores, governos, empresários e prestadores de serviços turísticos.

No entanto, Magaldi (1992) apud Santos (2006) alerta para a atitude adotada pelos planejadores quando da regularização e da preservação do patrimônio. Normalmente, tais planejadores abraçam posições favoráveis à especulação e a sua descaracterização. Para a autora, o dano causado e até a destruição do patrimônio cultural, é, muitas vezes, maquiado com o discurso da reestruturação, da renovação, da revitalização, apresentando-se como um processo de modernização.

A valorização do patrimônio cultural causa certa ilusão na sociedade, de uma maneira geral são realizadas "reconstituições históricas fantasiosas, demolições arbitrárias e restaurações inqualificáveis" (Santos, 2006, p.120). Com a valorização do patrimônio cultural em ritmo crescente, há o aumento de número de visitantes nas áreas tombadas. Essa situação pode ocasionar, de forma mais rápida, a deterioração destes lugares e, desse modo, ser capaz de se transformar em motivo de banalização do patrimônio.

É desafiador descobrir táticas para proteger e incentivar a conservação do patrimônio cultural, obtendo-se benefícios econômicos através do turismo. Tais táticas devem ser implantadas com seriedade por todas as pessoas compromissadas com o desenvolvimento do turismo. 
O crescimento proveniente do turismo pode ter como resultado a perda das relações de vizinhança e da identidade que dá sentido aos lugares e provocar a fragmentação do território e a segregação social. Dentro deste contexto de reorganização espacial, o planejamento do turismo surge como uma necessidade. Desse modo, com o objetivo de conservar o patrimônio, Santos (2006, p. 14) ressalta que:

[...] o planejamento torna-se um importante instrumento não só de preservação das formas, como de atribuições de novos usos a estas, o que implica não comprometer a preservação do sítio histórico e também os significados deste para a população local.

Isto posto, deve-se sempre estar disponível para refletir e trabalhar modificações práticas e concetuais, sempre que necessário, com relação ao patrimônio cultural, ao seu contato e a sua integração com a comunidade onde está incorporado. Importante, também, é analisar esse todo de atividade como parte de uma edificação cultural.

Conclui-se, pois, que o planejamento requer compreensão, conhecimento e distribuição harmônica entre os atores e características do espaço turístico estudado. Crê-se que o planejamento do turismo integrado admite que todos aprendam. Nesta situação, é importante que as pessoas envolvidas compreendam melhor os problemas enfrentados na organização de um planejamento. Igualmente importante é se sensibilizar por tal ação e contribuir para que todas as dificuldades sejam vencidas, sentindo-se envolvidos no processo e responsáveis pela obtenção de resultados eficientes.

No âmbito desta dissertação, as particularidades do município de São Luiz do Paraitinga requerem um projeto que possa auxiliar em diversos campos da prática do turismo. O planejamento há de abranger não apenas um recurso ou localidade, por exemplo, o patrimônio arquitetônico do meio urbano, como também o seu entorno. Ressalta-se que as atividades turísticas também se destacam, embora com menos intensidade, nos espaços rurais e naturais. Tal fato elucida a importância dos levantamentos de dados e informações provindas de diversos temas e, com a contribuição da cartografia temática, serão identificadas áreas apropriadas para o turismo na configuração territorial do município. 


\section{Capítulo 3}

\section{CARTOGRAFIA E TURISMO}

\subsection{Cartografia Temática e Turismo}

A cartografia temática é uma forma de comunicação que tem atuado no desenvolvimento do turismo desde o seu surgimento, em primeiro lugar, como atividade social, consequentemente e, ao depois, como econômica com repercussão na organização espacial. A cartografia, em especial nas tarefas de planejamento e gestão do turismo, constitui um instrumental bastante útil em muitas concepções da atividade turística. É preciso, no entanto, preocupar-se com a linguagem da representação gráfica. Esta tem uma série de especificidades que devem ser conhecidas por quem deseja utilizá-la.

De acordo com Martinelli (2001b, p. 157), tal como aconteceu com os outros setores temáticos, "a cartografia do turismo nasceu a partir do acréscimo sucessivo de elementos específicos ao mapa topográfico, principalmente em manifestações pontuais".

Durante o primeiro estágio da evolução do turismo, final do século XIX e início do século XX, algumas viagens turísticas foram documentadas. Percebe-se isso nas enciclopédias de viagens as quais mostram ilustrações, estatísticas, anúncios, etc. Eram utilizados, também, os mapas topográficos que continham, além dos nomes dos lugares, a representação das altitudes por meio de curvas de nível ou mediante tons de cor e, por vezes, cotas das elevações e os dados de coordenadas geográficas, todavia esses mapas só podiam ser interpretados por pessoas instruídas e experientes (MÚJICA, 2007).

No do século XX, começava a produção e divulgação de uma cartografia voltada para a circulação de automóveis, isto é, os mapas rodoviários, os quais são considerados um marco significante na evolução dos mapas turísticos. Nesta época, guias turísticos eram elaborados pela Shell (companhia de petróleo), nos Estados Unidos e pela Michelin (marca de pneu), na França. Esta continua sendo referência para os turistas nos dias atuais.

A Michelin enxergava o futuro do automóvel como absoluto. Para incentivar o desenvolvimento da indústria automobilística e, por conseguinte, a demanda por pneus e outros produtos, a Michelin decidiu oferecer aos motoristas franceses um documento que facilitasse suas viagens. Apresentou um pequeno guia e mapas rodoviários com localização de 
itinenários, postos de gasolina, oficinas mecânicas, dentre outos. A demanda pelos guias foi tão grande que, a partir da década de 1920, novas informações foram acrescentadas como a localização e classificação de hostéis e restaurantes ${ }^{18}$ (VIAMICHELIN, 2013).

Na década de 1930, a Alemanha também colocou alguns mapas no mercado. Tais mapas empregavam uma cartografia detalhada e rigorosa, com informações turísticas. No entanto, com o decorrer dos tempos, os mapas turísticos começaram a perder sua natureza científica e se subordinaram às necessidades do turismo que se desenvolvia. A linguagem estética ou tipicidade predominou nas publicações desse período. Nos idos de 1960, deu-se à estética um reforço especial, bastante trabalhada. Porém, na década seguinte, com o avanço das ciências cartográficas, os mapas turísticos, paulatinamente, foram se aperfeiçoando e se tornando um novo campo do saber geográfico (MÚJICA, 2007).

Na década de 1970, o geógrafo André Libault (1975, p. 220) mostrou a cartografia do turismo como um campo de pesquisa da geografia: “as próprias cartas turísticas já constituem um domínio particular que pode representar um novo campo de pesquisa para os cartógrafos". Apesar disso, o avanço da cartografia do turismo como ramo de estudo dentro da ciência geográfica foi tímido, aparecendo somente em congressos, encontros e seminários como "Comunicações". A partir do ano 2000, alguns trabalhos de formação superior versaram sobre o assunto, dentre estes há o estudo da cartografia voltada para o planejamento e outros para os aspectos pictóricos, analisando mapas turísticos existentes ou propondo metodologias para confecção de mapas turísticos, as quais se serviram da geotecnologia.

Na concepção de Martinelli (2001a, p.297), a cartografia do turismo ainda não atingiu sua completa sistematização. Diante disso:

Deverá persistir muita conjunção de esforços entre os estudiosos desse setor de pesquisa geográfica com o fim de dinamizar tal forma de comunicação em prol do esclarecimento da sociedade sobre o turismo. A cartografia do território usado pelo turismo pode ser vista como um ramo especializado da cartografia temática, mesmo que ainda não tenha sido sistematizada, diferentemente de alguns ramos da cartografia temática que já possuem certa sistematização, como as representações feitas para geologia, geomorfologia, climatologia e outras disciplinas.

A cartografia do turismo é um ramo da cartografia temática envolvido com a representação de aspectos atinentes ao turismo, enquanto, também, atividade econômica e sociocultural. De acordo com Martinelli (2001a, p. 296), sua sistematização “deve partir de

\footnotetext{
${ }^{18}$ Mais de um século depois, este princípio fundador é o denominador comum de todas as diferentes publicações e, hoje, os guias Michelin atendem mais de 25 países. Apresentam conteúdos turísticos diversos, como o contexto histórico do lugar e seus principais atrativos por meio de mapas turisticos impressos e/ou digitais.
} 
uma posição crítica de como é entendido este importante fenômeno social na atualidade para que ela possa verdadeiramente contribuir para o turismo".

A cartografia e o turismo têm em comum o espaço geográfico como objeto de estudo. Abrangem, em síntese, os elementos e aspectos existentes nas paisagens naturais e sociais. $\mathrm{O}$ turismo, ao desenvolver-se neste espaço, demanda, além da organização social e provimentos em infraestruturas, o emprego de recursos financeiros no desenvolvimento da prática turística por meio de múltiplos mecanismos e estudos, entre eles, a ciência cartográfica.

A cartografia temática, neste sentido, pode contribuir a partir de sua função básica, como o registro de pontos, linhas e áreas de interesse, orientações de itinerários, além das mais variadas representações dos fenômenos que compõem o espaço turístico. As informações contidas nos mapas, mesmo que não abarquem a totalidade, possibilitam uma representação do território que expressem a concretude do espaço consumido pelo turismo (MARTINELLI, 2001a). Assim como outras formas de comunicação, tais quais os folhetos de divulgação e placas informativas, os mapas devem mostrar o conteúdo dos lugares, apontar seus atrativos e/ou potencialidades turísticas.

Dentro deste contexto, a cartografia possibilita que a apresentação dos dados turísticos sob a forma gráfica torne-se um documento essencial a ser utilizado, uma vez que permite ao turista e gestores uma visão geral do espaço geográfico, desde o processo de pesquisa, planejamento, marketing, avaliação e até a efetuação de um possível reordenamento territorial.

As orientações para a elaboração de um mapa temático mostram a importância da qualidade técnica sob o prisma da aplicação da cartografia no segmento turístico, evidenciando reflexões sobre o conhecimento dos profissionais responsáveis no processo, para que os trabalhos desenvolvidos tenham respaldo científico, técnico, social e econômico.

Os mapas voltados para o turismo são projetados para demonstrar feições e conceitos específicos, que são concebidos por meio de $\operatorname{signos}^{19}$ referentes a peculiares atributos e variáveis, que melhor atendam ao propósito do mapa, facilitando a leitura pelo usuário.

A cartografia temática, observada pela representação gráfica nas atividades turísticas, não pode ter, como tradicionalmente acontece, uma função apenas ilustrativa. Concorda-se com Martinelli (1994, p. 63):

\footnotetext{
${ }^{19}$ Signo é uma unidade linguística - associação de um significante e um significado -, objeto perceptível que remete a outro objeto da realidade a que o signo faz referência. Já o símbolo é um objeto físico a que se dá significação moral, como exemplo, bandeira, brasão, pombo branco, dentre outros. Ao considerar a representação gráfica como uma linguagem, o correto é usar o termo signo no lugar de símbolos (MARTINELLI, 2011).
} 
[...] deve constituir-se em um meio lógico capaz de revelar, sem ambiguidades, o conteúdo embutido na informação mobilizada e, portanto, dirigir o discurso do trabalho científico de forma abrangente, esclarecedora e crítica, socializando e desmistificando o mapa, enaltecendo assim, a especificidade social da ciência cartográfica.

Os mapas turísticos devem constituir e se apoiar nas bases de percepção visual nas mais diversas formas, sejam diversidades, ordens ou proporções. São confeccionados para serem vistos e sua legibilidade instantânea, para que tenham condições de produzir imediata assimilação e o mínimo de ruído na comunicação visual. A escolha de signos na cartografia deve se basear em estudos sobre o tratamento gráfico dos dados, assim como no conhecimento das limitações e potencialidades dos utentes aos quais os produtos se destinam, nesse caso, as atividades turísticas. Ou seja, aplicar a Semiologia Gráfica nos mapas turísticos é realizar a transcodificação da linguagem escrita para a linguagem gráfica e evitar interferências na comunicação, buscando signos que, de fato, representem as características mapeadas (BERTIN, 1973; 1977).

Dentro de um processo cognitivo da comunicação cartográfica, o ruído perturba a relação emissor/receptor dificultando, ou até mesmo impede a comunicação. Na cartografia, o ruído acontece, por vezes, por falhas no emissor (falta de conhecimento em cartografia e em tratamento gráfico dos dados para a correta escolha das formas de representação), no canal de comunicação (quando o mapa não apresenta legenda, ou conta com baixa resolução gráfica, ou os desenhos são mal elaborados) e no receptor (falta de conhecimento mínimo de cartografia e representação espacial, tais como orientação, escalas, uso de um mapa temático) ou no código (quando este não é de domínio pelos dois sujeitos, o emissor e o receptor) (MOURA; RIBEIRO, 1999).

É relevante salientar que os signos, quando sozinhos, possuem diversos significados. Dessa forma, a elaboração de uma legenda tem a finalidade de relacionar os signos e decodificar seus significados na linguagem verbal corrente. Isso possibilita uma leitura objetiva do tema abordado. Conforme exalta Martinelli (2011, p.22), "a legenda é o momento da simbolização, um guia de leitura do mapa”.

No entanto, o que definirá o teor e a intencionalidade proposta pelo autor é a estrutura da legenda. Neste tocante, a legenda assume uma magnitude a qual extrapola a essência do enunciado do mapa. Expõe, ainda, um pensamento que retrata não somente a percepção do seu autor, como também, traz à tona reflexos da sociedade na qual ele vive.

Os mapas para o turismo podem congregar, também, outras representações, como blocos-diagramas e perfis. De acordo com Martinelli (2001b, p.160), os blocos-diagramas são 
"mapas tridimensionais perspectivos" e apresentam uma imagem intuitiva da realidade. Os perfis possibilitam uma visualização em projeção vertical da paisagem, ressaltando em silhueta o delineamento do conteúdo. "A silhueta da Torre Eiffel é inconfundível. O perfil do Pão de Açúcar é notável” (MARTINELLI, 2001b, p.161).

No que tange a importância conferida à imagem turística, a propaganda amplia o conhecimento do público e faz dos mapas objetos comercializáveis. Neste âmbito, Martinelli (2001a, p. 152) aponta que "[...] a imagem que podemos produzir venderá o espaço turístico, espaço produzido para aquele fim. Para tal busca, as imagens evocarão paisagens, sejam naturais ou culturais".

A cartografia do turismo associada à imagem adita uma forte tendência de agregar novas representações gráficas como meio de comunicação visual e é capaz de promover grande impacto na motivação do turismo. Além de orientar e coordenar lugares, os mapas são capazes de fornecer informações de como desfrutar, de forma racional, do lugar turístico escolhido.

Esta cartografia, como veículo de comunicação, permite ao usuário sentir-se inserido no espaço turístico, tendo noções de direção, distância e facilitando a tomada de decisão, como a escolha de determinados lugares para seu melhor aproveitamento (DUQUE; MENDES, 2006, p.83-84).

Dentro deste contexto, torna-se possível apontar múltiplas alternativas de representação cartográfica e usufruir de diferentes recursos de signos, desenhos, fotografias, grafismo, entre outros. Aconselha-se, nesta situação, o uso de escalas, coordenadas ou quadriculadas.

A utilização de símbolos dirigidos aos turistas exigem cuidados específicos, isto porque, por trazerem dentro de si valores culturais, podem tornar mais fácil ou mais difícil a compreensão do fenômeno representado. Não por outra razão, recomenda-se a utilização de símbolos pré-existentes e de singela compreensão, que sejam suscetíveis de serem decifrados pelo público, mesmo que não tenham know-how da ciência cartográfica (ALMEIDA; GUERRERO; FIORI, 2007).

É certo que as viagens se tornaram mais acessíveis, particularmente as internacionais, ativando sobremaneira o turismo, impôs-se, desse modo, a criação de um sistema de comunicação universal. Diante disso, na representação gráfica dos objetos como os atrativos turísticos, a visualização é facilitada para turistas que não têm o hábito da leitura de mapas (a maioria), quando tais elementos aparecem numa visão frontal ou oblíqua (como se observados 
de um plano elevado e meio de lado) e em desenhos que se assemelhem aos objetos reais - as representações pictóricas.

Recomenda-se, destarte, ser visto com cautela, o uso das formas pictóricas as quais imitam o objeto a ser representado, não obstante, com esse uso, a comunicação possa ser facilitada. Tal fato sucede porque, para muitos temas, nem sempre é possível encontrar signos para retratá-los de forma eficiente. Por vezes são abstratos e o conceito do leitor a respeito deles pode variar bastante. Ademais, é possível se encontrar signos pictóricos difíceis de serem entendidos. E, ainda, é necessário advertir que os signos pictóricos são capazes de alterar de significado de um contexto histórico ou cultural para outro (OLIVEIRA, 2005; 2007).

No entanto, os mapas do tipo "pictóricos" são bastante utilizados para o turismo, pois transmitem informações essenciais as quais, muitas vezes, ultrapassam as barreiras comunicativas e têm a função de orientar o comportamento social. De acordo com Almeida, Guerrero e Fiori (2007, p. 65), “este tipo de comunicação é aplicado na maioria dos países, mesmo que seus traços gráficos sejam elaborados de maneira e formas diversas".

Exemplos significativos são os mapas elaborados pela Michelin, que desde seu lançamento, usufruíram de pictogramas que evoluíram com o tempo (figura 08).

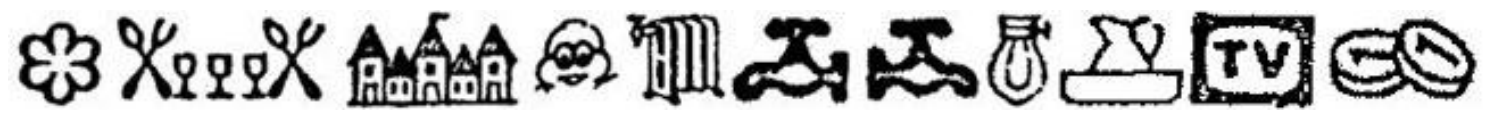

Figura 08 - Pictogramas utilizados pela Michelin no início do século XX Fonte: Via Michelin, 2013.

Atualmente, diversos signos pictográficos também são apresentados pelas instituições privadas e órgãos públicos, como por exemplo, alguns modelos de pictogramas utilizados pelo Ministério do Turismo no Brasil (figura 09). 


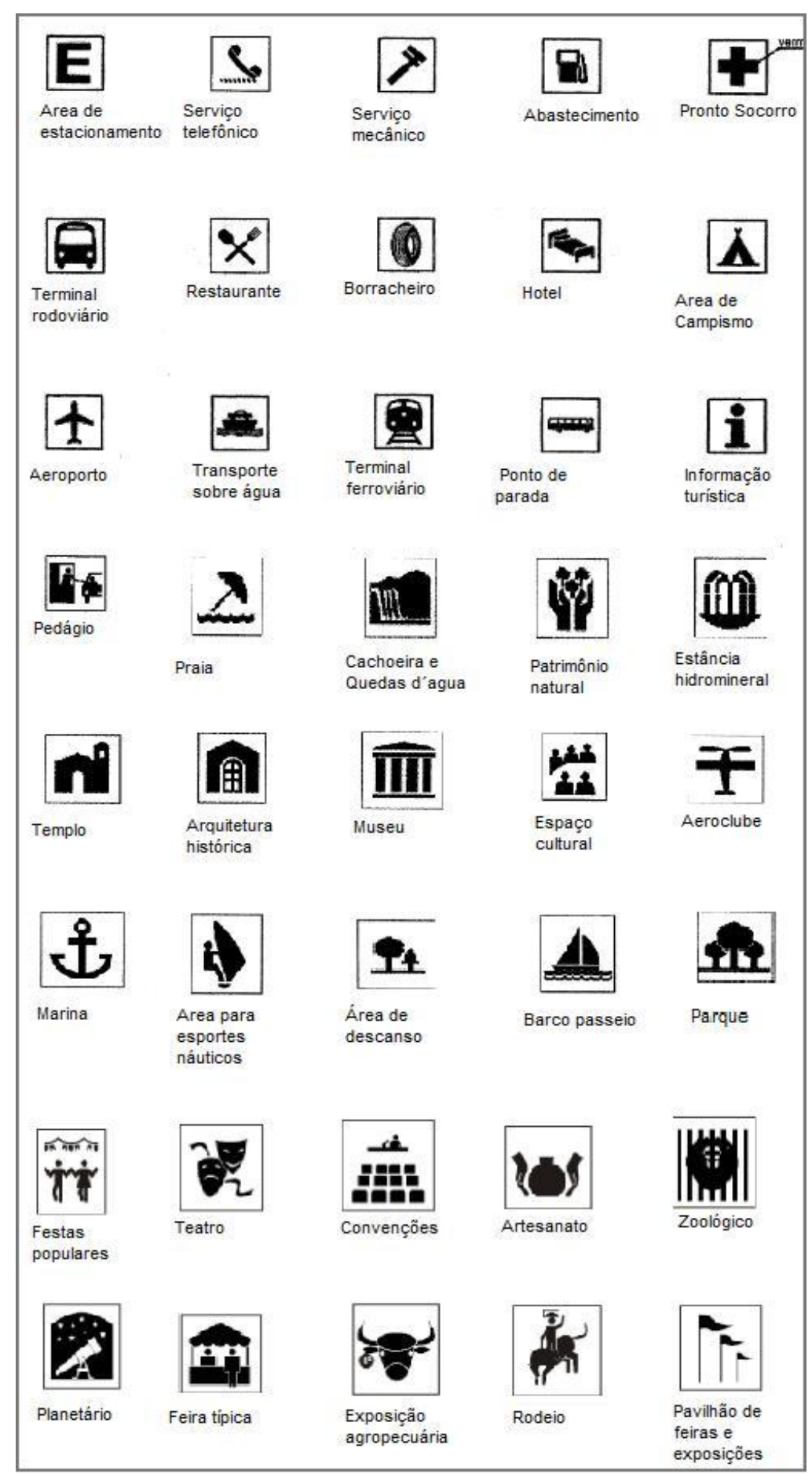

Figura 09 - Atuais pictogramas utilizados pelo Ministério do Turismo Fonte: Ministério do Turismo, $2012^{20}$.

O uso exagerado de elementos pictóricos em mapas turísticos causa grande impacto na comunicação, mas, apesar disso, desperta, à saciedade, o desejo de conhecer o lugar. Esses mapas, entretanto, são caracterizados por uma maior poluição visual e algumas graves

\footnotetext{
${ }^{20}$ Disponível em <http://institucional.turismo.gov.br/sinalizacao<br/>/conteudo/principal>. Acesso em $10 \mathrm{de}$ dezembro de 2012.
} 
deficiências cartográficas, tais como: ausência de escala, desconhecimento do sistema de referências e de legendas que cumpram, de maneira correta, sua função. Há, além disso, muitas vezes, a distorção da base cartográfica, sendo flagrante, por exemplo, a omissão de parte das ruas, as quais deveriam ser integrantes do ambiente. Todos esses itens adicionados dificultam, sobremaneira, o deslocamento e a localização dos diversos pontos da localidade.

Como mostra a figura 10, o mapa turístico de Londres é um encarte ampliado de uma região bastante visitada. Projetaram-se os elementos pictóricos em perspectiva ${ }^{21}$ para atingir uma maior proximidade com a realidade representada dos patrimônios edificados. Foram inseridos sobre o fundo do mapa que registra o arruamento. Essa colocação, no entanto, não resulta em descontinuidade na leitura para aqueles que desejam se deslocar ao longo da cidade. Em contrapartida, o usuário deve estar atento aos nomes das vias, já que a escala utilizada (desconhecida) não permite a aparição de todos os segmentos viários e isso pode dificultar sua localização no lugar. A supressão das ruas, dentro de um contexto de generalização cartográfica, por vezes ocorre a fim de não "sobrecarregar" o mapa.

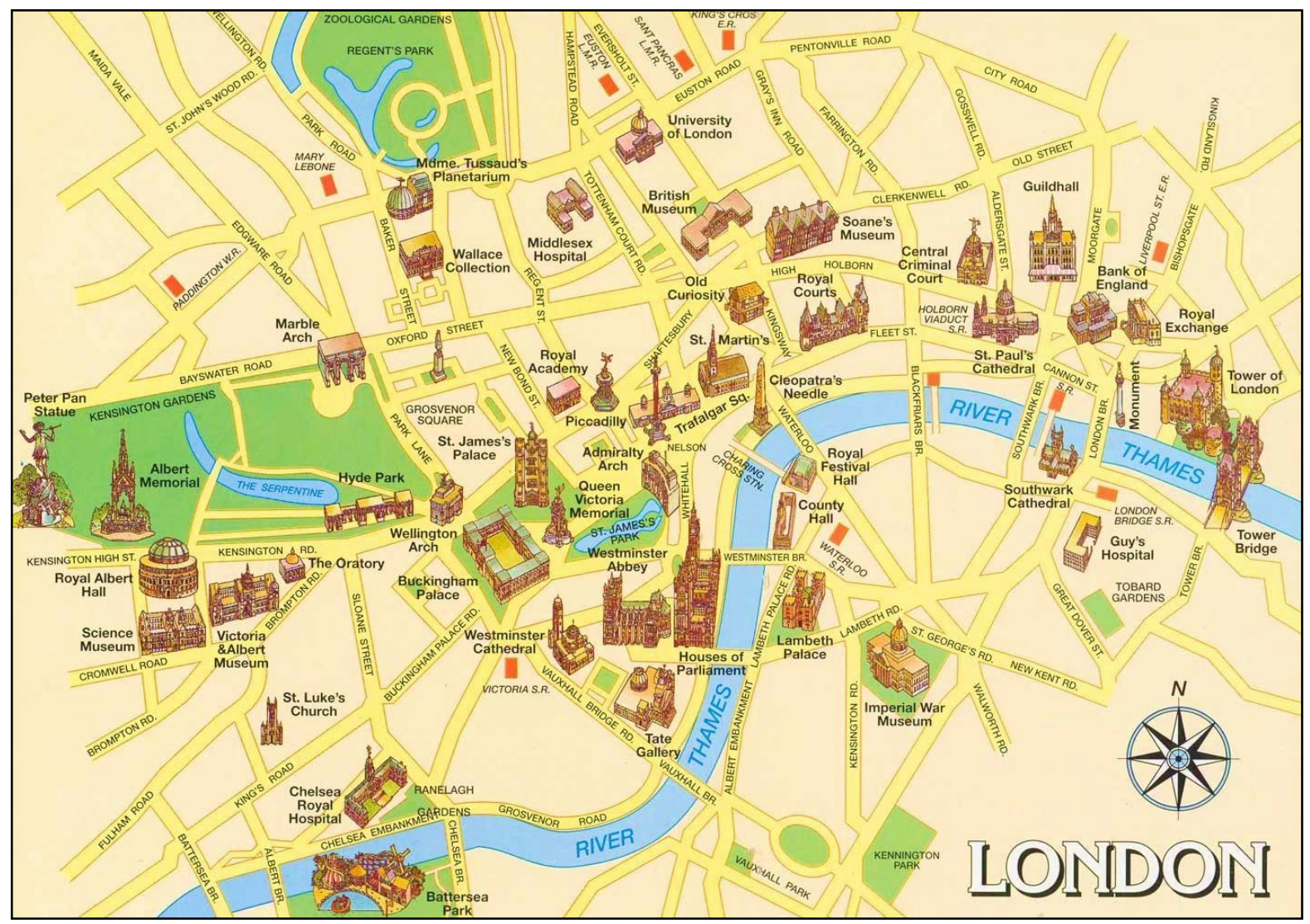

Figura 10 - Mapa dos principais atrativos turísticos de Londres (Inglaterra) em 2009 Fonte: Organização não governamental (ONG). Arquivo pessoal.

${ }^{21}$ A grande vantagem da leitura em perspectiva é a possibilidade de análise, em termos, de conjunto espacial na percepção sinótica. Ou seja, o usuário deixa a visão horizontal da informação para atingir a visão quase vertical, vista de "cima". 
Assim como o mapa apresentado na figura anterior, o mapa turístico de Canelas (figura 11) também possui uma cartografia de base com um arruamento sem escala, permitindo que as formas geométricas simples das ruas sejam compreendidas com facilidade. A novidade nesse mapa são as fotografias. Martinelli (2001a, 2001b) advoga que à legenda podem ser apostas também fotografias dos respectivos argumentos dos significados dos signos, o que enriquece, em muito, o mapa, possibilitando maior aproximação do usuário ao seu conteúdo e garantindo-lhe maior alcance social.

$\mathrm{Na}$ realidade, é muito comum não atribuir uma correta localização das imagens ao longo da cidade. Isto ocorre porque as figuras estão alinhadas, o que gera forte encadeamento entre as mesmas. Na figura 11, as fotografias codificadas por números enaltecem os objetos referentes, associando a comunicação polissêmica à monossêmica, porém, uma legenda especificamente organizada para associar fotos aos significantes dos signos possibilitaria um entendimento mais amplo desse espaço turístico (MARTINELLI, 2001b).

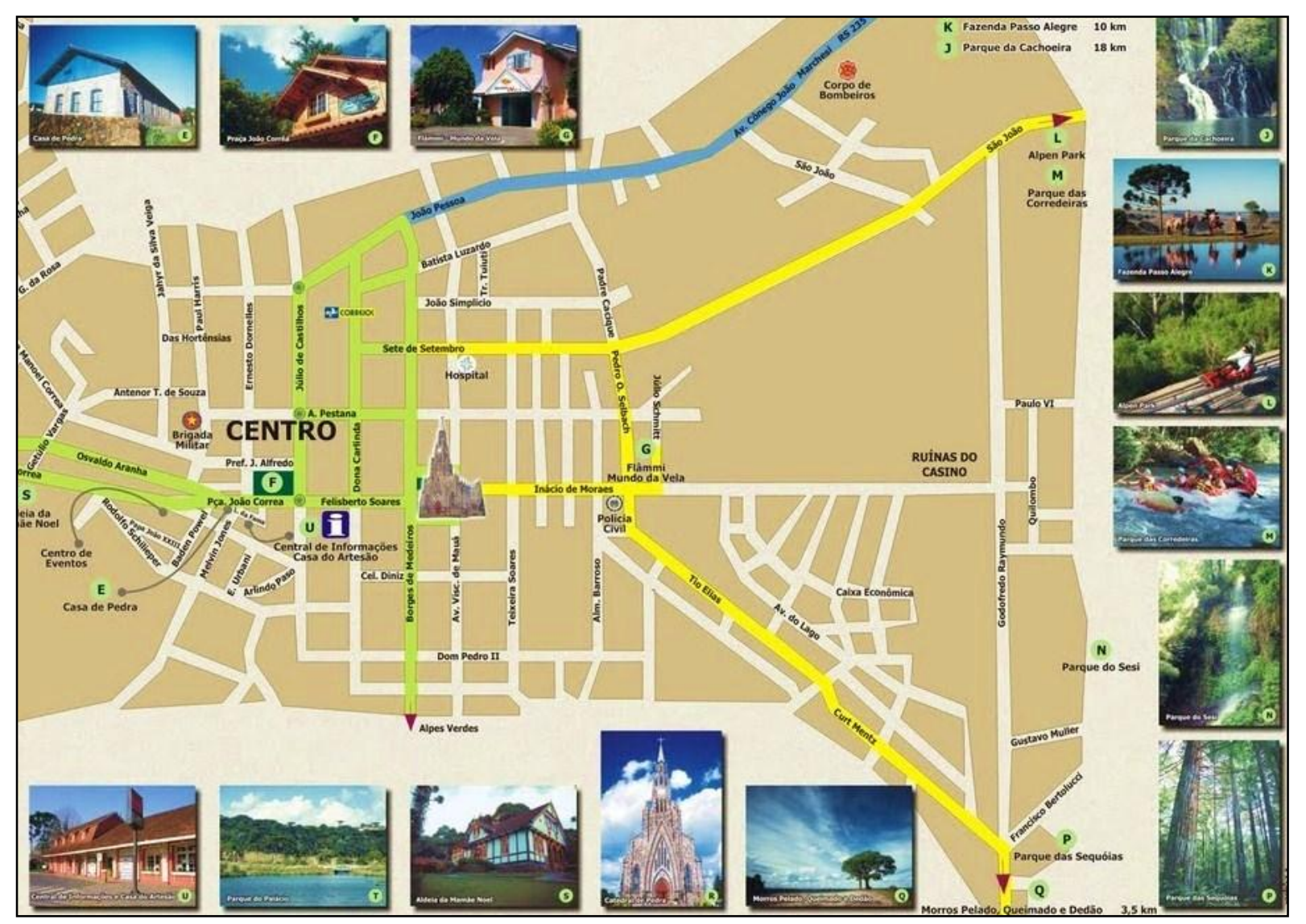

Figura 11 - Trecho do mapa turístico de Canelas (RS)

Fonte: Associação Comercial Industrial de Canelas - ACIC - sem data. Arquivo pessoal.

Distinto dos mapas demonstrados anteriormente, o mapa turístico da Ilha Grande (figura 12), mostra os atrativos turísticos por meio de uma representação gráfica, utilizando 
símbolos e elementos pictográficos, todos monocromáticos. Ao representar a topografia da ilha por símbolos monocromáticos pontuais na legenda, gera uma dificuldade de discriminação dos elementos gráficos. Este mapa, hoje, é atípico e pouco utilizado pelos planejadores e divulgadores do mercado turístico, pois não apresenta elementos fundamentais para atrair a atenção do usuário, sobretudo quando se trata de ilustrações e cores.

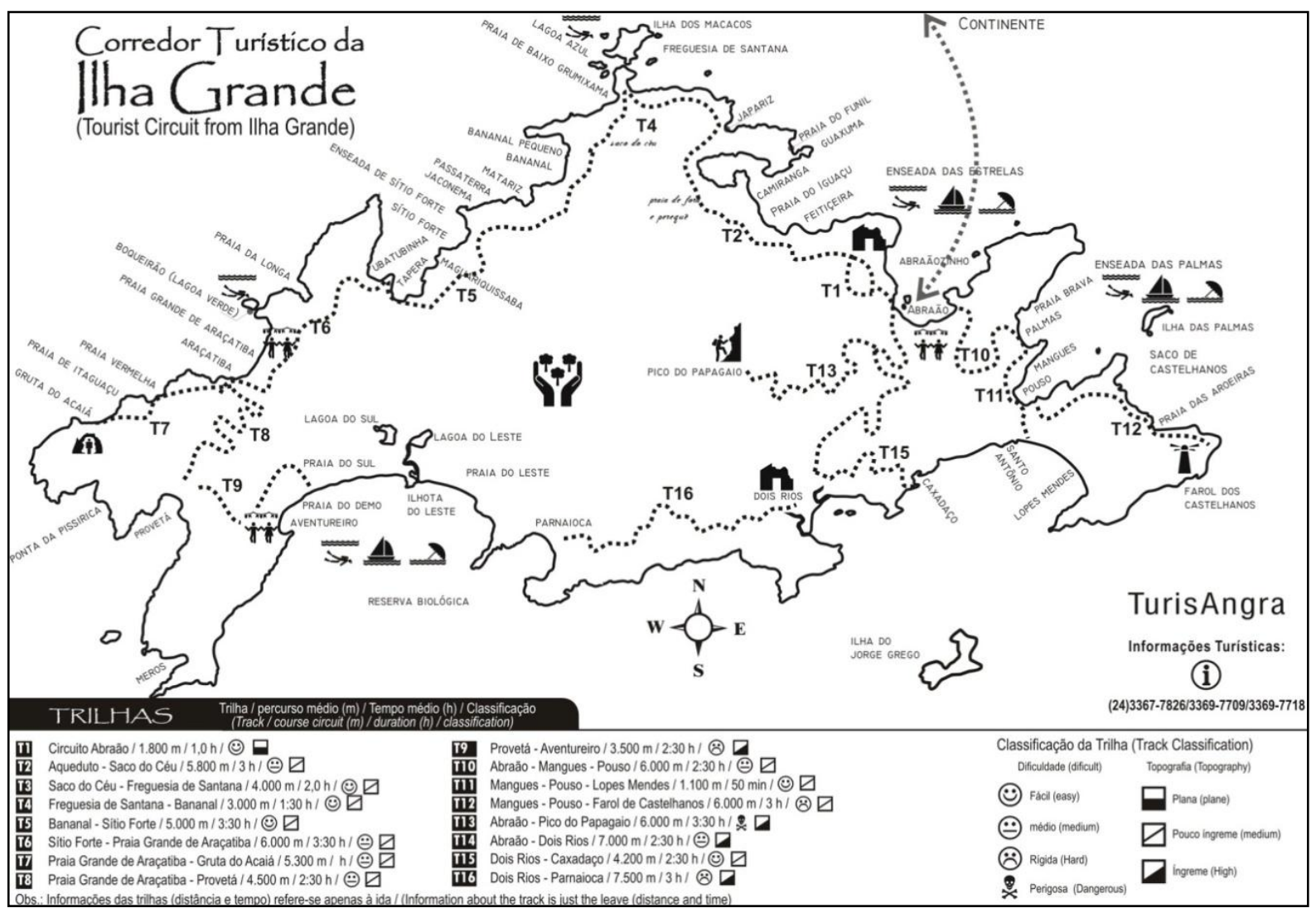

Figura 12 - Mapa do corredor turístico da Ilha Grande (RJ)

Fonte: Fundação de Turismo de Angra dos Reis, sem data. Arquivo pessoal.

Na figura 13, o Mapa Turístico do Círculo Italiano de turismo rural de Colombo (PR), dispõe de título, localização da área, orientação e escala. Esta última muito rara em mapas turísticos. Também são apresentadas as vias (asfaltadas e de saibro) e suas respectivas quilometragens. Nota-se, outrossim, que neste mapa há a demarcação de quilometragem e escala gráfica, ou seja, existe redundância, sem exageros, no intuito de reforçar a comunicação. De acordo com Moura e Ribeiro (1999, p. 3):

A redundância não traz nenhuma informação nova, mas é utilizada com o objetivo de combater o ruído, para reforçar o processo de comunicação. No caso de um mapa turístico, podem ser utilizadas tanto anotações da quilometragem ao longo das estradas, como também o desenho da escala gráfica. Não seria necessário utilizar ambos os elementos, mas sua utilização conjunta reforça o processo de comunicação. Contudo, o excesso de redundância também pode causar danos à comunicação, pois causa desinteresse do receptor quanto ao conteúdo da informação. 


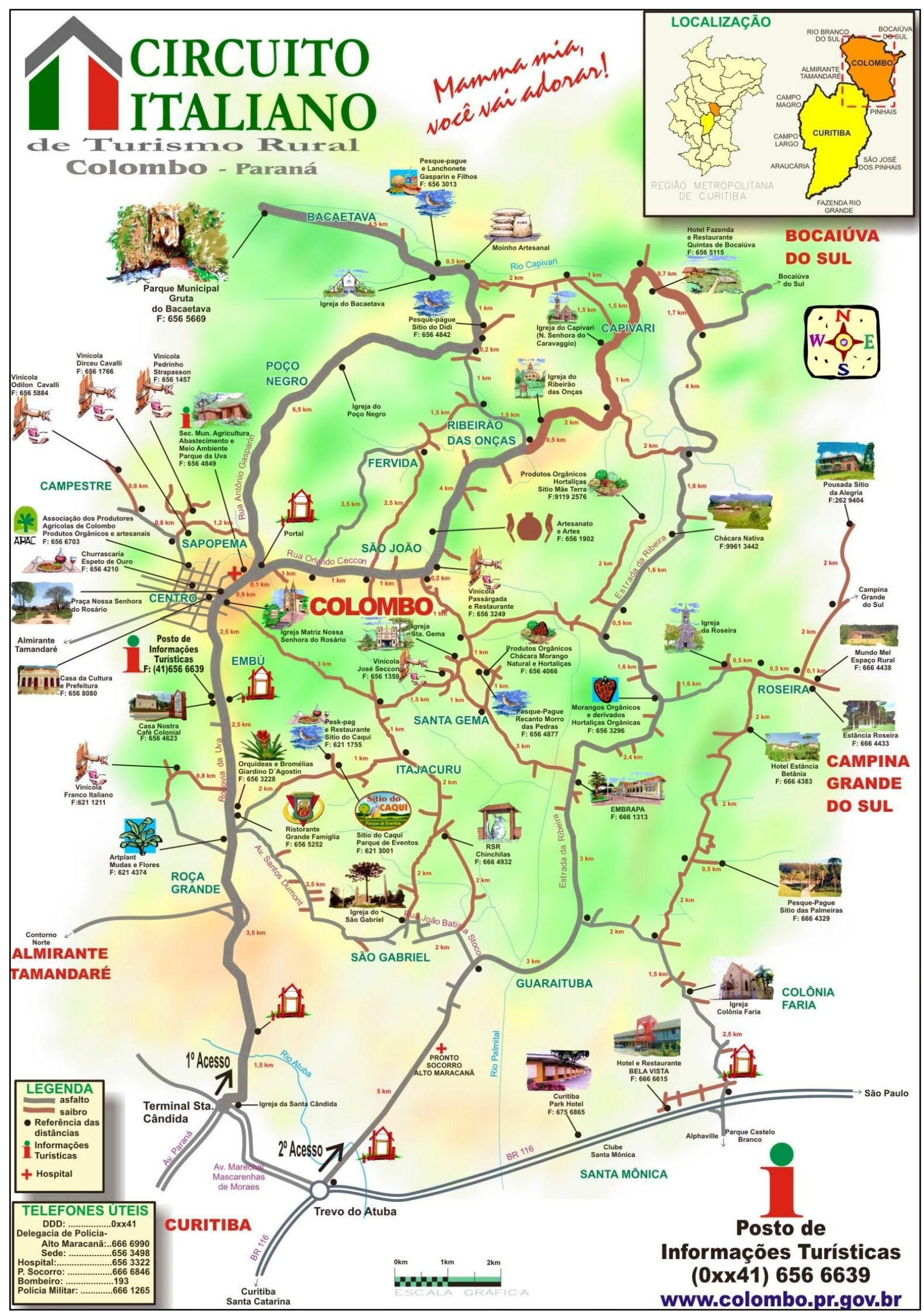

Figura 13 - Mapa turístico do Circuito Italiano de turismo rural em Colombo (PR) Fonte: Prefeitura Municipal de Colombo, 2010²2.

${ }^{22}$ Disponível: 〈http://www.gilsonantunes.com.br/Mapas/ITALIANO-mapa.jpg〉. Acesso: 10 de abril de 2012. 
Apesar disso, o mapa turístico do Circuito Italiano exibe uma diversidade de elementos pictóricos, fotografias, logotipos, entre outros, além de textos descritivos dos mesmos, o que dificulta a leitura pelo usuário. Ocorre, neste mapa, um excesso de informações. O uso da cor verde-limão do fundo também atrapalha a leitura por ser uma gradação "forte" e se destacar diante das demais informações.

Por se tratar do objeto de estudo deste trabalho, apresenta-se, na figura a seguir, um mapa turístico pictórico da cidade de São Luiz do Paraitinga. O grafismo (pinturas ou desenhos) são recursos utilizados pelos mapas turísticos que pretendem uma aproximação representativa semelhante à realidade do espaço. A figura 14 apresenta-se como um mapa promocional, confeccionado por meio de grafismo tridimensional, que serve de estímulo à visitação do lugar, por conta da atraente imagem turística vista pelos usuários (turistas).

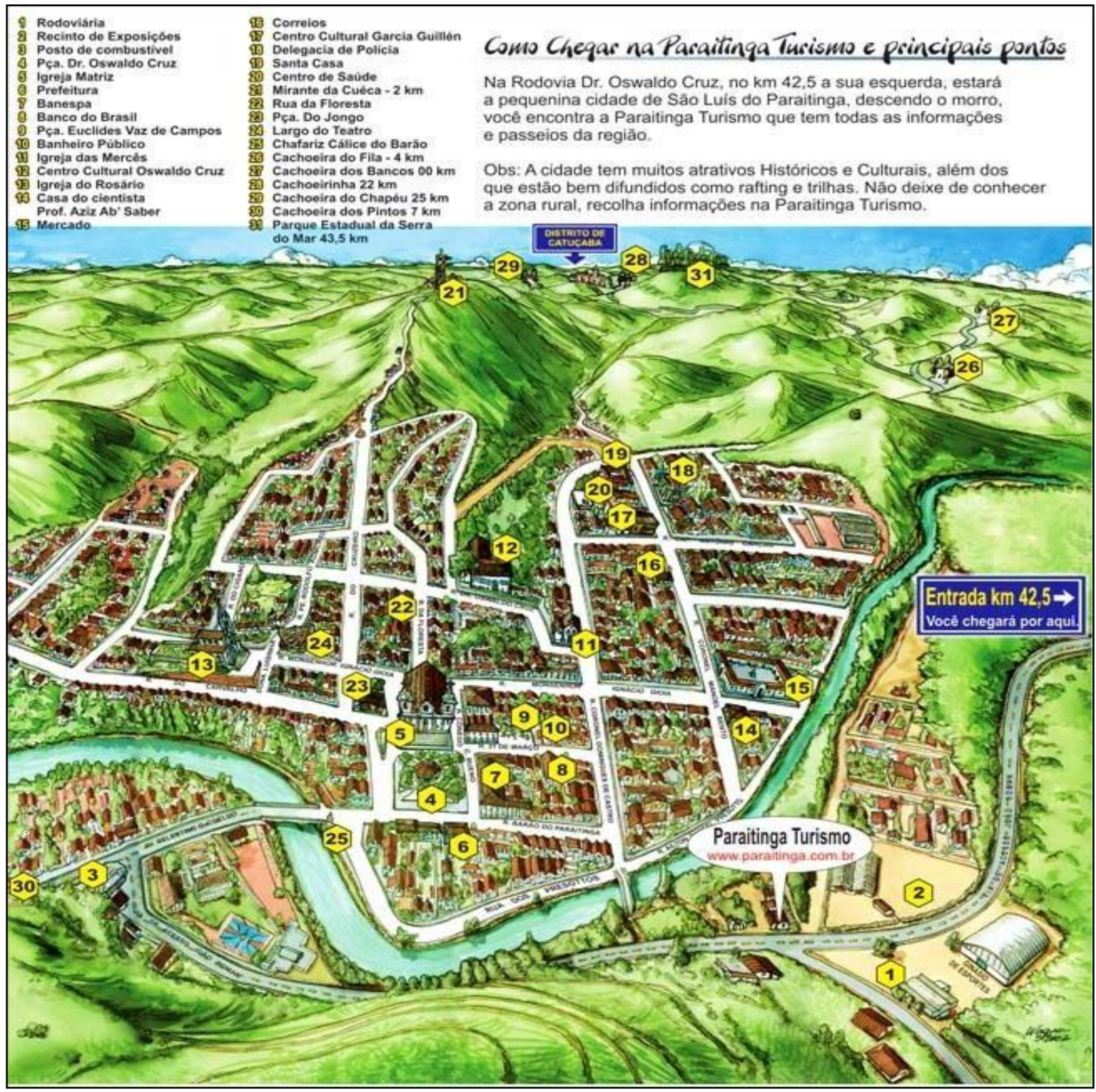

Figura 14 - Mapa turístico pictórico de São Luiz do Paraitinga (SP)

Fonte: Paraitinga Turismo: aventura \& cultura, sem data. Arquivo pessoal. 
O mapa de São Luiz do Paraitinga também mostra codificações numéricas e a localização dos principais atrativos por meio de legenda, porém, a ausência de referências dificulta sua leitura.

Coloca-se em destaque, diante dos mapas apresentados, que a cartografia temática do turismo, quando destinada ao turista, trabalha, em especial, com paisagens que podem ser graficamente representadas e atua, também, com o espaço, cujas formas que compõem a paisagem têm como função responder às necessidades do visitante. Observa-se isso nos mapas que mostram atrações, naturais e culturais, atividades e serviços situados em um determinado lugar turístico (FIORI, 2010). Para tanto, a noção de escala (distâncias), direção (orientação) e posicionamento (coordenadas geográficas) são requisitos recomendáveis para quaisquer mapas voltados para o turismo, porém, pouco utilizados nos exemplos de mapas citados.

É preciso, ademais, observar com cuidado essa "universalidade" (sistema de comunicação) dos símbolos e desenhos que são códigos nos mapas promocionais. Tais mapas exibem símbolos que são, por sua própria natureza, dinâmicos, portanto, mutáveis com o evoluir dos tempos. Uma cor que é símbolo do amor para uma sociedade, pode não o ser em outra. Ou mesmo o desenho de um animal utilizado para identificar o zoológico, é capaz de perder seu valor caso, futuramente, este atrativo seja extinto.

Como se observa, a cartografia é uma edificação cultural e, em razão de sua natureza, retrata um cenário panorâmico social, econômico, histórico e político. Como toda cultura, encontra-se em permanente transformação. A cartografia - inclusive a cartografia do turismo - não é composta por uma linguagem expressa (ou explícita) a partir de símbolos realmente universais.

A preocupação de quem vai construir um mapa está em saber retratar as relações que se estabelecem entre os objetos, fatos e os fenômenos, e não na exaltação das relações entre significante (o estímulo físico, o desenho) e significado (a ideia). Observa-se, no entanto, que os mapas turísticos devem constituir e se apoiar nas bases de percepção visual, nas mais diversas formas, sejam diversidades, ordens ou proporções. Devem ser elaborados de forma cuja assimilação seja instantaneamente vista, bastante legível e com poucas interferências. 


\subsection{Novas tecnologias adotadas à Cartografia do Turismo}

Há décadas, o mapa era representado apenas em meio analógico. Mas, hoje, o desenvolvimento da tecnologia informacional fez com que houvesse uma mudança substancial na forma de apresentação e usufruto da ciência cartográfica. Embora tais tecnologias não sejam o foco central deste trabalho, acredita-se que esta temática deva ser apreciada por compor todo o complexo de possibilidades que a cartografia oferece.

Quando se trata de turismo, diferentes tipos de mapas apoiados nas ciências geográficas, cartográficas e informacionais são oferecidos aos usuários por meio da internet, sejam eles pesquisadores, gestores ou turistas. Entre eles estão os mapas rodoviários, mapas urbanos e naturais, localização de atrativos turísticos, de serviços e infraestrutura, utilizados como meio de comunicação, motivação e planejamento do turismo (MOURA, OLIVEIRA, LEÃO, 2006).

Peterson (1999) e Martinelli (2001a, 2011) entendem que por meio da internet são várias as combinações de textos, gráficos, animação, som e vídeo com o propósito de melhorar a comunicação, isto é, a coexistência de diversas formas de tecnologia para transmitir a informação. A internet serve como suporte para a combinação de mapas com outras mídias, visando representar o mundo de um modo mais real.

Os mapas da internet podem ser divididos em estáticos e dinâmicos. Ambos podem, ainda, ser apresentados e usados nas modalidades, em apenas vistos e interativos (RIZZI, 2010).

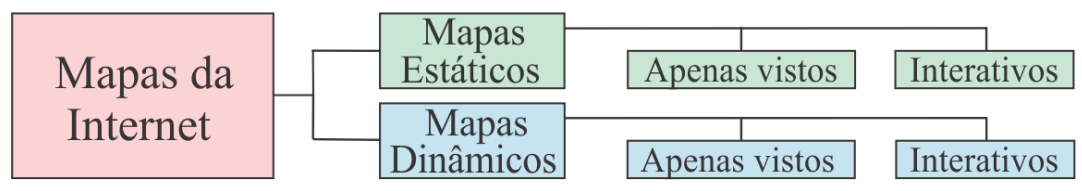

Figura 15 - Tipos de mapas da internet

Fonte: 〈http://kartoweb.itc.nl/webcartography/webmaps/classification.htm〉. Acesso: 24 de agosto de 2013.

Os mapas estáticos apenas vistos são, em sua maioria, digitalizados e colocados na rede em formato matricial (de regra em $\mathrm{GIF}^{23}$ ou $\mathrm{JPEG}^{24}$ ). Os mapas estáticos interativos, como o próprio nome diz, mostra uma situação de interação do usuário com a forma de visualização. Tais mapas são chamados de mapas "clicáveis", permitem que os usuários

\footnotetext{
${ }^{23}$ GIF (Graphics Interchange Format) é um formato de imagem muito usado na web, quer para imagens fixas, quer para animações.

${ }^{24}$ JPEG (Joint Photographic Experts Group) é um método comum usado para comprimir imagens fotográficas e é frequentemente considerado como um formato de arquivo. É o formato de imagem mais comum usado por câmeras digitais.
} 
escolham as camadas ativas no mapa, além de poder alterar as cores, símbolos e outras modalidades de visualização do tema retratado.

Já os mapas dinâmicos apenas vistos podem ser denominados como GIF $\operatorname{animados}^{25} \mathrm{e}$ os mapas dinâmicos interativos são criados por meio de linguagens de programação Java ou ambientes virtuais criados em VRML ${ }^{26}$. As animações inventadas por esta linguagem são capazes de armazenar um modelo 3D dos objetos e, a partir da interatividade com o usuário, este é capaz de definir o caminho de viagem, e tomar decisões sobre os rumos, distâncias, altitudes, tempo, etc.

Segundo Peterson (1999), a cartografia interativa desenvolveu-se a partir da necessidade de se apresentar a informação geográfica de uma maneira mais intuitiva, permitindo que o usuário perceba mais facilmente os fenômenos representados. Os mapas interativos representam uma mudança fundamental para a ciência cartográfica e os impactos dessa transformação facilitam a visualização cartográfica na criação e difusão de novos produtos.

Por outro lado, observa-se que os métodos "tradicionais" de representação em cartografia estão menos consistentes, quando considerados dentro do paradigma da evolução tecnológica, porém não estão errados, buscam sim, como representar a informação geográfica com a utilização de novas técnicas e tecnologias. Dentro deste contexto, Griscon (1996) apud Peterson (1999, p. 31) afirma que "enquanto a tecnologia digital expande o potencial e o alcance perceptivo da humanidade, a mensagem do meio impresso não é obsoleta ou insustentável, mas reposicionada dentro de uma realidade de conhecimento maior".

Mediante a utilização de novas tecnologias, torna-se possível criar um ambiente virtual suportado pelos mapas que funcionam em "camadas" e permitem navegar através deles com alterações de escala, proporcionando a visualização de deslocamento em condições interativas no tempo e no espaço. De acordo com Martinelli (2011), tais representações ocupam posição de destaque dentro das vertentes atuais da cartografia, por considerar que a contemporaneidade admite conceber a realidade essencialmente mutante e fluída.

Dessa forma, para uma possível eficácia da cartografia interativa é preciso, a priori, coletar, organizar e armazenar dados e representar as informações do espaço geográfico em ambiente computacional, procedimentos que culminam no advento da prática do geoprocessamento.

\footnotetext{
${ }^{25}$ GIF animado é um termo dado às animações formadas por várias imagens GIF compactadas em uma só.

${ }^{26}$ VRML (Virtual Reality Modeling Language) é um padrão de formato de arquivo para realidade virtual, utilizado tanto para a internet como para ambientes desktop.
} 
O geoprocessamento é caracterizado por Xavier da Silva (2001, p.12), como:

[...] conjunto de técnicas computacionais que opera sobre bases de dados (que são registros de ocorrências) georreferenciados, para os transformar em informação (que é um acréscimo de conhecimento relevante).

Em sucintas palavras, considera-se o geoprocessamento como um conjunto de tecnologias, métodos e processos para o processamento digital de dados e informações geográficas. Este se tornou um dos principais mecanismos a serviço do trabalho cartográfico, bastante empregado em diversas áreas da pesquisa no âmbito geográfico. Os instrumentos utilizados no geoprocessamento que se destacam são: Cartografia Digital (CD), Sistema de Informações Geográficas (SIG), Sistema de Posicionamento Global (GPS), Sensoriamento Remoto (SR) e Banco de Dados Geográficos (BDG) (SCALCO, 2006).

Com o avanço do geoprocessamento nos trabalhos acadêmicos e técnicos, torna-se comum na cartografia o uso dos SIGs para se elaborar mapeamentos temáticos. Com o advento do SIG, a comunicação cartográfica assumiu maior significado e novos desafios foram superados, como a criação de diferentes produtos para aprimorar a eficácia da transmissão informativa e o melhor entendimento do processo comunicativo. A representatividade visual dos dados explora a habilidade do sistema visual humano para reconhecer padrões e estruturas espaciais. Isto fornece uma melhoria na aplicação crítica e compreensiva dos dados, beneficiando a análise, o processamento e as decisões posteriores.

Uma série de softwares de cartografia digital, muitas vezes integrada aos SIG, oferece uma gama de soluções construídas com bases nas propostas metodológicas cristalizadas junto ao setor da cartografia temática. A tecnologia SIG, como se pode depreender, tornou-se uma significante contribuição para as ciências que trabalham com processos os quais ocorrem na dinâmica do espaço e tempo.

Isto posto, fatores como pontos turísticos, serviço de apoio, proximidade de centros de informações turísticas, classes de vegetação, transporte, estudo da paisagem, entre outros, são incorporados a um SIG e classificados com diferentes valores, com o intuito de caracterizar zonas específicas de um destino (SCALCO, 2006).

A difusão de mapas por meio da internet também mostra outro importante meio com o qual a tecnologia informacional interfere na ciência cartográfica e suas repercussões. Sites como o Google Maps, Google Earth, Bing Maps, dentre outros, são exemplos de projetos cartográficos gratuitos, que permitem ao usuário não somente visualizar o espaço em diferentes escalas e perspectivas, como também, em alguns casos, acrescentar conteúdos que se somam à base de dados existentes e interligada a outros elementos de multimídia são 
capazes de permitir uma "viagem pelo mundo". A disponibilização online de mapas e informação georreferenciada, de serviços básicos e de apoio ao turismo podem ser determinantes na escolha final do destino para este novo perfil de turista.

A partir dessa análise é possível observar, com clareza, a influência sobre o impacto da informação turística sistematizada através de SIG em ambiente web, na motivação para o turismo. Para isso, verifica-se a relação entre espaço e paisagem no processo de escolha de destinos turísticos, bem como a ligação entre cartografia e geoprocessamento e suas contribuições para a comunicação no turismo.

Vislumbrando a atividade turística, as contribuições das geotecnologias à cartografia tendo como objetivo o turismo são empregadas para destacar certa localização e especificar a dinâmica dos fenômenos espaciais, abarcando modificações em tamanhos de objetos, forma, posição, velocidade, ponto de vista, distância, cena, textura, padrão, sombreamento e coloração, vistos em mapas animados e interativos (NODARI; BECKER; CANALE 2006).

Os mapas elaborados por meio da hipermídia ${ }^{27}$ proporcionam a visualização espacial de um dado geográfico como complementar à informação de base através de textos, imagens e fotografias, que podem ser acessadas por meio dos hipermapas. "Pode-se, portanto, definir o hipermapa como um mapa interativo, que permite ao usuário acessar uma série de informações georreferenciadas por meio de hiperlinks" (RAMOS, 2005, p. 85).

Utilizando-se os canais dos hiperlinks, é possível obter uma navegação espacial e virtual com a visualização das informações contidas no banco de dados do SIG. Nodari, Becker e Canale (2006, p. 717) ressaltam os benefícios de um hipermapa turístico:

Com o SIG pode-se realizar consultas aos dados de algumas empresas voltadas para o turismo, podendo acessar informações como, por exemplo, telefone e endereço. Também há a possibilidade de atualizar informações espacialmente georreferenciadas, podendo trazer benefícios como um melhor planejamento e expansão de novas áreas e das condições turísticas da região. Outra possibilidade é a elaboração de mapas de acordo com a necessidade do turista.

Por intermédio dos hipermapas, tornou-se plausível a visualização espacial a fim de facilitar pesquisas sobre distintas áreas do conhecimento geográfico, inclusive o turismo. Tais mapas são disponibilizados na internet como mostra a figura 16.

\footnotetext{
${ }^{27}$ Segundo Laufer \& Scavetta, hipermídia é a união de várias mídias em um suporte computacional, composto por sistemas eletrônicos de comunicação capaz de interligar documentos textuais e visuais em sistemas informacionais. Hipermídia une os conceitos de não lineares, hipertexto, interface e multimídia numa só linguagem. Disponível em: http://pt.wikipedia.org/wiki/Hiperm\%C3\%ADdia. Acesso em 12 de março de 2012.
} 

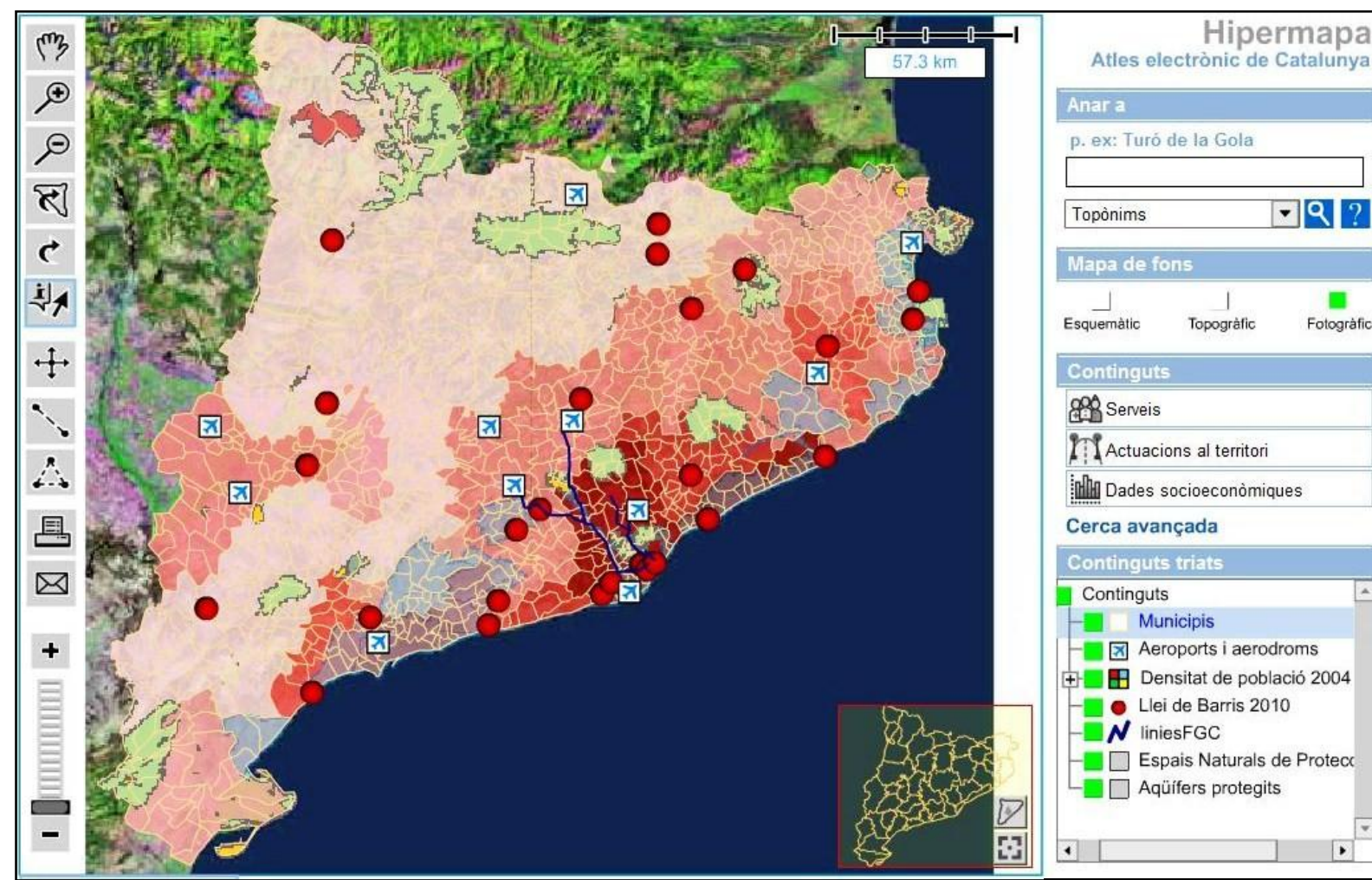

Figura 16 - Hipermapa interativo da Catalunha (Espanha)

Fonte: <http://hipermapa.ptop.gencat.cat/hipermapa/client/15120/base_cat.html> Acesso em: 12 de fevereiro de 2012.
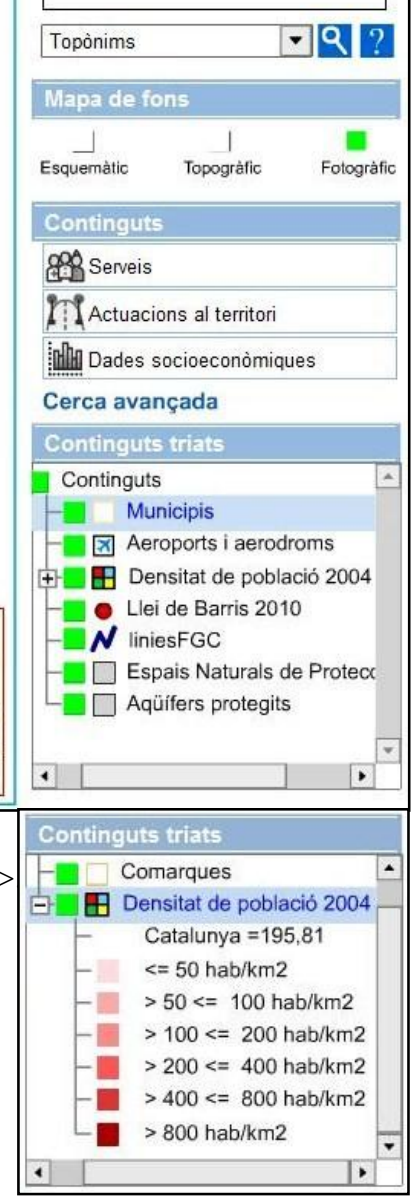

No hipermapa interativo da Catalunha, é possível realizar diversos tipos de pesquisas que auxiliam na elaboração do planejamento turístico para gestores e turistas. Nesse "recorte" apresenta-se toda a expansão da província e foram selecionados alguns elementos como limites municipais, aquíferos e áreas ambientais protegidas (polígonos). Aeroportos, centros históricos e bairros (pontos), além das principais ferrovias (linhas), também fazem parte da seleção. Nota-se que é plausível, por intermédio dos hipermapas, elaborar mapas temáticos. Nesse caso, foi gerado um mapa coroplético da densidade populacional, usufruindo de cores graduais representadas na legenda.

Diversas são as informações disponíveis nesse hipermapa:

1. Saídas: esquemático, topográfico ou fotográfico;

2. Serviços: administração, educação, cultura, meio ambiente, comércio, indústria, hospedagem, telecomunicação, transporte, uso e ocupação do solo, entre outros;

3. Ações no território: planejamento urbanístico, plano diretor, investimentos imobiliários, entre outros; e, 
4. Dados socioeconômicos: população (densidade, taxa de crescimento, natalidade e mortalidade, etc.), economia (renda familiar), trabalho (ocupação e estabelecimento, etc.), educação (número de matriculados em escolas públicas e privadas, universitários, nível médio e superior, etc.), meio ambiente (geração de resíduos sólidos, coleta seletiva, etc.).

No hipermapa a seguir (figura 17), aproximou-se a escala, dando enfoque a uma área da cidade de Barcelona. Optou-se pela saída de mapa topográfico e alguns ícones foram apresentados como hospitais, mercados municipais, museus, bibliotecas, portos, estações de trem, além de um trecho de sugestão de rota turística histórica.

Dadas as informações disponíveis, torna-se possível saber as coordenadas geográficas, alterar cores, transparências, espessuras dos traços e escalas. O mapa é interativo e ao clicar em cada símbolo surgem novos hiperlinks com informações sobre o setor, através de um amplo banco de dados que inclui, também, combinação de textos, arte gráfica, som, animação e exibição de vídeo.

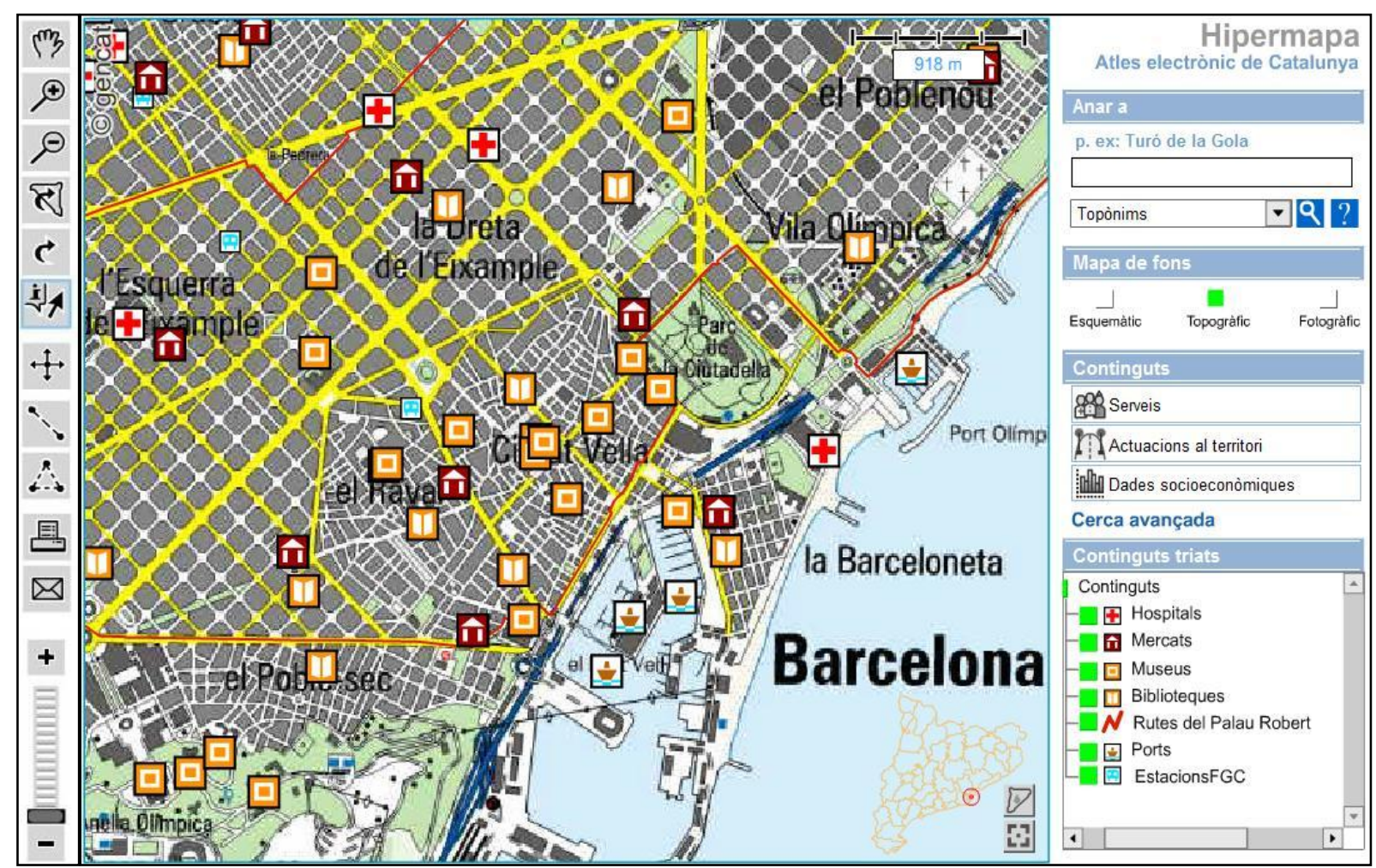

Figura 17 - Hipermapa interativo da Catalunha (Espanha) com enfoque na cidade de Barcelona Fonte: 〈http://hipermapa.ptop.gencat.cat/hipermapa/client/151208/base_cat.html>. Acesso em: 12 de fevereiro de 2012.

Por meio dos exemplos apresentados, afirma-se que a visualização cartográfica, transmitida por computador, amplia de maneira significativa a difusão das informações 
espaciais, assim como desperta o interesse do usuário na exploração do espaço, culminando numa maior interatividade entre utente e mapa (MARTINELLI, 2011).

Assim, aliado à navegação virtual, o geoprocessamento tem exibido duas grandes vantagens para o turismo: disponibilização de informações de um inventário turístico (antes somente consultadas pelos planejadores e depois engavetadas) e uma estratégia de marketing turístico eficiente (pois um maior número de informações é captado pelo inconsciente do usuário), barato e de alcance mundial, que diminui as incertezas do consumidor na hora de optar pelo destino turístico.

As informações colhidas na internet oferecem algumas vantagens como atualizações constantes, possibilidade de customizações (reprodução ou impressão apenas de interesses, criando, um guia personalizado) e a probabilidade de visualizar as informações em outros meios digitais portáteis como palm tops, GPS ou telefones celulares.

Diante de tais possibilidades, conclui-se que, nessa linha de raciocínio, a cartografia, quando usufruída por intermédio das geotecnologias à atividade turística, proporciona admirável gama de informações disponíveis para a gestão e planejamento do turismo. Disponibiliza, também, informes detalhados aos demais usuários e turistas.

\subsection{Cartografia para o planejamento do turismo}

Os mapas contribuem para o planejamento ao agregar dados coletados e georreferenciados, os quais são tratados e transcritos por uma representação cartográfica, revelando-se como um eficaz veículo de comunicação de informações espaciais (DUQUE; MENDES, 2006).

Além dos mapas turísticos apresentados neste capítulo, é pertinente evidenciar que Martinelli (2001a), Martinelli e Ribeiro (2002) e Oliveira (2005; 2007) também destacam a utilidade da cartografia para o planejamento turístico. Ressaltam a importância de se conhecer a linguagem da representação gráfica e suas especificidades as quais devem ser respeitadas na elaboração de mapas temáticos sobre o turismo, para que não ocorra a transmissão de informações equivocadas. Tal repercussão pode ser observada, nos últimos anos, através de diversas pesquisas cartográficas que utilizam as diretrizes do planejamento do turismo com o intento de compatibilizar e adequar a ocupação dos espaços que, por vezes, de forma inadequada, causam graves ou irreversíveis consequências ao ambiente. 
Oliveira (2005) afirma que para cooperar com o planejamento do turismo, a cartografia precisa ser pensada desde o emprego dos mapas nas etapas de diagnóstico da potencialidade turística de um determinado lugar ou para a implantação de um espaço turístico, até a implementação ou consolidação e da avaliação de uma atividade turística.

Em todos os casos, a cartografia deve amoldar sua linguagem ao tipo de representação gráfica que será construída. A disposição e a seleção dos elementos em um mapa turístico são essenciais, e tanto a cartografia topográfica como a cartografia temática trazem esse suporte para análise dos dados a serem tratados, antes de serem dispostos no mapa. A cartografia de base serve de referência geométrica para análises espaciais em diferentes aplicações, sempre que se requer distribuição espacial dos dados ou informações (OLIVEIRA, 2007).

Um mapa com a topografia de uma área, expressando as altitudes em curvas de nível e pontos cotados, por exemplo, pelo fato de já vir associada à rede de drenagem e, com a complementação da vegetação, facilita a identificação de diferentes atrativos como cachoeiras e corredeiras, mirantes, vales e planícies, cidades e fazendas, além dos acessos a trilhas, estradas, rodovias, entre outros. É plausível agregar, também, o uso de fotografias aéreas e imagens de satélites (figura 18). O cruzamento de várias informações, como a infraestrutura, o uso da terra e cobertura do solo na região, bem como o conhecimento das comunidades que habitam o lugar, seu modo de viver e relações econômicas não deve ser ignorado. Deste ponto, pode-se determinar se o local é elegível como atrativo e qual é seu potencial para o desenvolvimento do turismo (OLIVEIRA, 2005; DUQUE; MENDES, 2006).

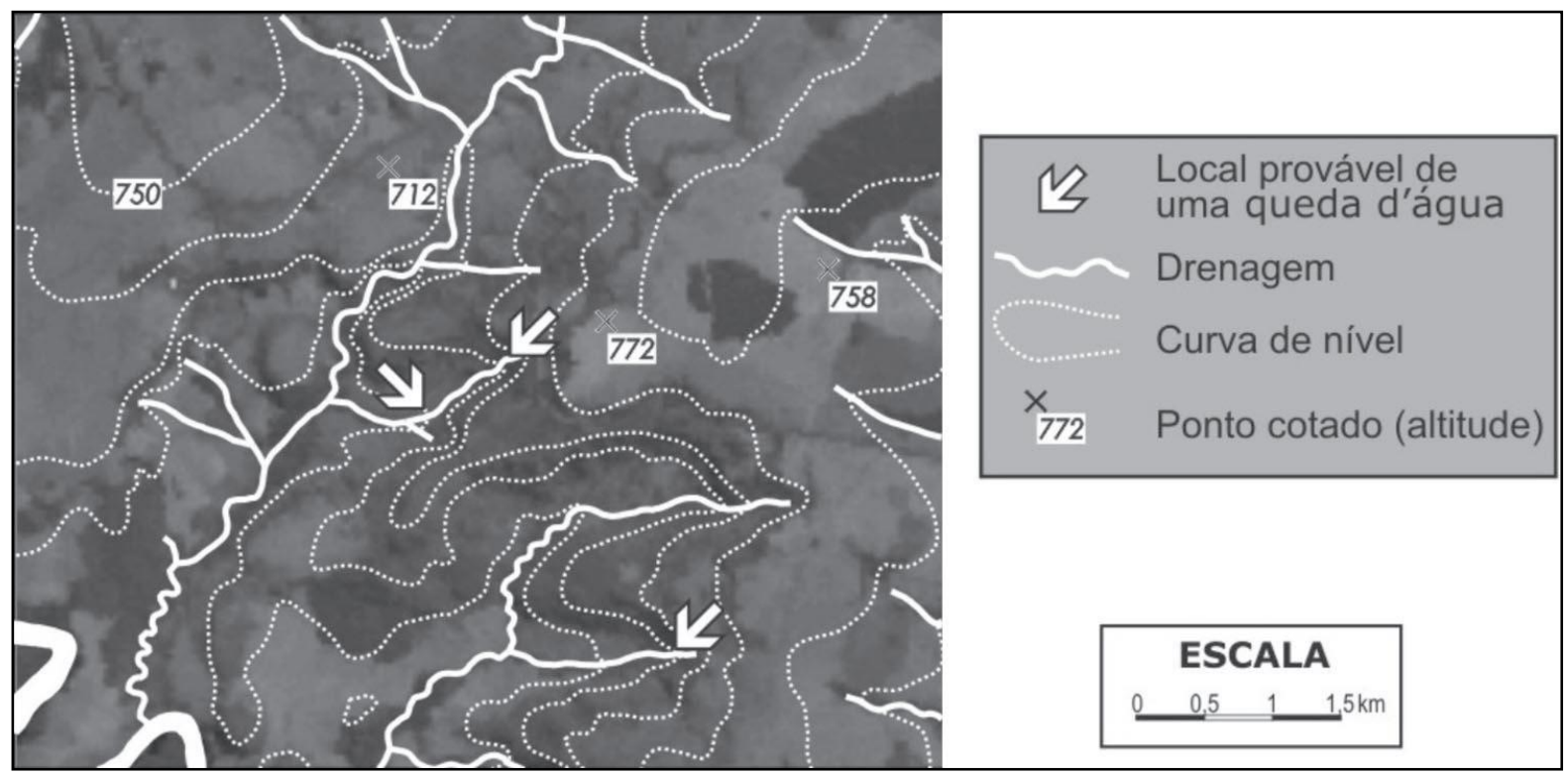

Figura 18 - Imagem de satélite combinada com dados altimétricos e rede de drenagens Fonte: OLIVEIRA, 2005, p. 36. 
Considera-se um grande ganho, nessa fase do planejamento, utilizar-se do geoprocessamento, de maneira particular quando se parte do cruzamento dos mapas temáticos básicos, utilizando os SIGs. Uma das grandes vantagens desses sistemas é o fato de consentirem a integração de dados de diferentes fontes numa mesma base, adaptando diversas escalas e distintas projeções. Com um SIG é possível, por exemplo, realizar uma 'análise de proximidade', por meio dos buffers, para demonstrar quantos bares e restaurantes estão situados próximos a praça central, dentro de um limite de 500 metros de largura, a partir de sua borda ou centróide. É importante, outrossim, "realizar-se o cruzamento de informações de um mapa de uso da terra e cobertura do solo com outro que localiza os prováveis atrativos da região, com a finalidade de se constatar os problemas quanto à incongruência de uso (o lugar tem uma potencialidade turística como balneário, mas é utilizado para a extração de areia, por exemplo)" (OLIVEIRA, 2005, p. 37).

Além disso, a cartografia também contribui de forma significativa ao processo de análise das atividades turísticas já implementadas e facilita a avaliação dos aspectos positivos e/ou negativos que possam ocorrer no futuro. $\mathrm{Na}$ avaliação da atividade turística, a cartografia é importante pois trabalha os dados quantitativos em potencial, os quais admitem sua contagem sob vários aspectos. Oliveira (2005) aponta como exemplo o número de turistas que visitam com assiduidade determinado atrativo, seu lugar de origem, bem como suas características econômicas e socioculturais; a infraestrutura a disposição dos turistas (como o número de pousadas/hotéis), acessibilidade (rodovias, aeroportos, etc.), sinalização (placas informativas), comércio e serviços (bancos, correios, etc.). Estes aspectos exigem a coleta sistemática dos dados. O cruzamento de mapas temáticos, por sua vez, favorece a avaliação da distribuição da infraestrutura de determinado espaço geográfico e serve de suporte para o planejamento de atividades turísticas.

Por certo, a elaboração de tais mapas temáticos exige o conhecimento do assunto, tratado com bases científicas, para decidir quais dados serão ou não suprimidos em uma representação cartográfica. Martinelli (2001b, p.158) salienta que a representação da realidade do turismo, em suas diversas escalas e dimensões, deverão partir:

[...] de uma acurada sistematização teórico-metodológica voltada à representação da realidade turística, proporcionando sua compreensão a partir do potencial em recursos naturais, histórico-culturais e sociais, sejam de origem espontânea, sejam artificial, enaltecendo cada vez mais a realidade a partir do lugar com sua expressiva identidade de valor. 
Ao se partir dessa premissa, evidencia-se a essência da cartografia temática no processo do planejamento do turismo por consentir ideias rápidas, gerais e integradoras da situação espacial dos potenciais turísticos. Neste caso:

[...] o mapa ajuda muito na tomada de decisões e, principalmente, na representação espacial dos problemas. $\mathrm{Na}$ realidade, os mapeamentos temáticos tornam-se instrumentos que envolvem, pelo menos, três fases no planejamento, cada qual compreendendo um processo: a seleção e obtenção dos dados de entrada, a análise integrada e a elaboração de indicadores que servirão de base para a tomada de decisão (ZACHARIAS, 2006, p.19).

Associado aos fundamentos metodológicos da representação gráfica (semiologia gráfica), o turismo torna-se um importante objeto de pesquisa, em especial, quando se aborda o estudo da paisagem. Uma das possibilidades da cartografia do turismo aplicada ao planejamento constitui-se no levantamento das potencialidades das atividades turísticas agrupadas por tipos de paisagem. Isso acontece ao fornecer uma cartografia que busca representar por meios de mapeamentos temáticos a relação dos componentes que perfazem o espaço geográfico.

Martinelli e Pedrotti (2001, p.40) apresentam uma clara sintetização sobre a apreensão dos tipos de paisagem a partir da representação cartográfica. Dizem os autores que diante da cartografia:

[...] a paisagem é o que vemos diante de nós. É uma realidade visível. É uma visão de conjunto percebida a partir do espaço circundante. Não tem, assim, uma existência própria, em si. Ela existe a partir do sujeito que a apreende: Cada pessoa vê diferentemente de outra, não só em função do direcionamento de sua observação, como também em termos de seus interesses individuais.

Ante tal colocação, acredita-se que este subsídio só será possível por intermédio de mapas que possibilitem níveis diferenciados de leitura sob a realidade espacial representada. Assim, há de se considerar que, para se chegar à representação gráfica e visual da paisagem, podem ser sugeridas duas possibilidades de cartografia: analítica e de síntese.

A sensibilização a respeito da natureza e sociedade em seu movimento, que compõe a realidade concreta local, portanto, é o ponto de partida. Na busca deste conhecimento, a cartografia é essencialmente analítica. Todos os mapas de temas básicos em nível analítico como relevo, rede de drenagem, uso da terra, população, economia, infraestruturas e outros tipos de informações são recomendáveis, tanto na área rural como urbana.

A cartografia de síntese, por sua vez, propõe um mapa final, comumente chamado de mapa-síntese, fruto de uma integração de informações, da reconstrução do todo. Tendo-se, então, como base o mapa de síntese dos tipos de paisagem, pode-se chegar a um mapa de 
zoneamento (figura 19) que auxiliará o planejador nas tomadas das decisões para programar ações consistentes. No contexto deste trabalho, são estes mapas que indicam as áreas com potencialidades e fragilidades da realidade espacial e, desta maneira, permitem propostas para o planejamento turístico.

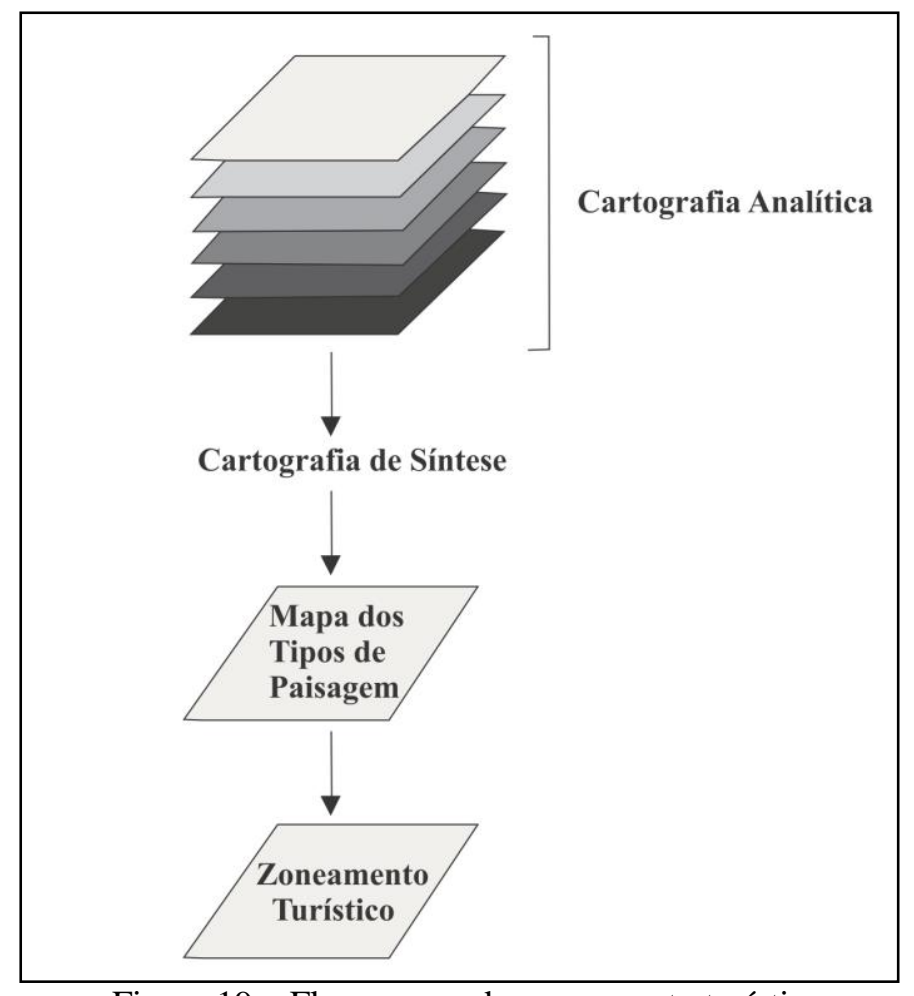

Figura 19 - Fluxograma do zoneamento turístico Fonte: Adaptado de ZACHARIAS, 2006, p. 116.

Doravante, é possível uma abordagem dinâmica através da elaboração de cenários gráficos (características definidoras da entidade turística geográfica ou os atributos que a qualificam), espaciais (refere-se ao posicionamento, forma e relações topológicas e geométricas entre as entidades espaciais) e temporais (refere-se à época de ocorrência do fenômeno turístico geográfico) (ZACHARIAS, 2006, 2008). Possibilita, destarte, uma ampla visão da realidade estudada. Duque e Mendes (2006, p. 10) apontam que:

[...] a combinação de situações ambientais pode gerar ganho de conhecimento sobre uma realidade existente, assim como permitir estudos de previsão de mudanças (cenários ambientais) e simulação de consequência de intervenção de paisagens.

Dentro de uma abordagem dinâmica e visando a construção de tipos de paisagens para chegar a definir os zoneamentos turísticos, por exemplo, a elaboração dos mapas temáticos por meio de dados estatísticos, históricos e cenários gráficos deve retratar um conteúdo concreto, como a relevância de uma análise integrada do espaço e o estudo das práticas sociais (ZACHARIAS, 2006, 2008). 
Esse caráter dinâmico da paisagem carece ser realizado de acordo com o interesse do pesquisador e dos objetivos propostos. É com bases nas análises espaciais que a cartografia temática veicula algumas vantagens nos processo de planejamento do turismo, tais como conhecer as potencialidades, fragilidades e vocações atuais e futuras da paisagem. A partir daí, este mesmo raciocínio pode ser usufruído para propor uma gestão integrada, proteger e recuperar os patrimônios culturais materiais e imateriais, assegurando o acesso a eles e compatibilizar atividades urbanas e rurais, com uso racional da infraestrutura, entre outros.

É importante que o redator estabeleça uma relação do cenário real (áreas visíveis do/no espaço terrestre) e o cenário gráfico (mapa com representação gráfica dos atributos das paisagens), fato que o leva desde a elaboração de mapas por temas (cartografia analítica) até o mapa síntese (cartografia de síntese). De acordo com Zacharias (2008, p. 38):

[...] favorecer a síntese, a objetividade, a clareza da informação e a sistematização dos elementos a serem representados. [...] Garantidas essas qualidades, os mapas temáticos podem ser os melhores instrumentos de comunicação entre os planejadores e atores sociais, dada sua possibilidade de ceder a leitura espacial, interpretação e conhecimento das potencialidades e fragilidades das paisagens, por meio de representações gráficas e visuais.

Martinelli (2001b) apresenta um claro apanhado sobre a apreensão dos tipos de paisagem a começar pela representação cartográfica. Apesar da relevância de tal fato, o autor supracitado destaca que, quando envolve a representação gráfica dos tipos de paisagem, a comunicação cartográfica ainda se constitui em um desafio.

Esta questão também se torna um dos desafios desta dissertação, isto é, elaborar uma cartografia de síntese que atenda as necessidades de uma adequada legibilidade quanto a representação dos diferentes tipos de paisagens, revelando, sem ambiguidades, o conteúdo embutido em sua informação gráfica e visual.

Para que a informação gráfica e visual do mapa seja de fato compreendida, faz-se necessário, prioritariamente, planejar os dados turísticos de forma que representem de modo real as singularidades do espaço estudado. Por isso, necessita-se entender a importância da cartografia nos trabalhos de planejamento turísticos, pela sistematização das representações gráficas da paisagem segundo suas características e potencialidades turísticas.

Em face do todo exposto, releva-se, igualmente, a importância de configurar o geoprocessamento como instrumento fundamental nas etapas de análise e sistematização da cartografia temática do turismo, pois utiliza as geotecnologias (inclusive a internet) para o processamento de dados com ênfase na localização geográfica, ordenação e manejo do turismo, elementos importantes para o planejamento das atividades turísticas. 


\section{Capítulo 4 \\ O MUNICÍPIO DE SÃO LUIZ DO PARAITINGA}

\subsection{Caracterização do município}

Incrustado no Vale do Paraíba, no Estado de São Paulo, a $180 \mathrm{~km}$ da capital, está um pequeno município, com cerca de 10 mil habitantes, cuja história fez com que, hoje, se tornasse no maior conjunto arquitetônico tombado do Estado de São Paulo: São Luiz do Paraitinga.

Com uma área de $617 \mathrm{~km}^{2}$, o município de São Luiz do Paraitinga possui uma topografia montanhosa e serrana, com uma altitude de 750 metros (na sede do município) e clima tropical de altitude. Sua precipitação pluviométrica média anual é de aproximadamente $1.300 \mathrm{~mm}$ e é rica em recursos hídricos.

Considerado uma das 29 estâncias turísticas do Estado de São Paulo, está encravado na Serra do Mar, tendo o município de Taubaté a noroeste e Ubatuba ao sul. Limita-se também, a oeste, com o município de Redenção da Terra; a sudoeste com Natividade da Serra. Divide fronteiras com Cunha a leste e Lagoinha a nordeste (figura 20). Pertence à Região administrativa de São José dos Campos e situa-se em relação à capital paulista a uma distância aproximada de 170 quilômetros.

A malha rodoviária, em ótimo estado, favorece bastante o interesse dos visitantes pela região. Esse fato resultou na especulação imobiliária e provocou sérias alterações na configuração do espaço, sociedade e economia.

Atualmente, o turismo urbano, rural e de natureza são fatores determinantes para o desenvolvimento econômico local. É de se pensar, portanto, na importância de promover os atrativos turísticos com cautela, dentro de um planejamento adequado, a fim de preservar o meio e evitar o declínio do lugar. 


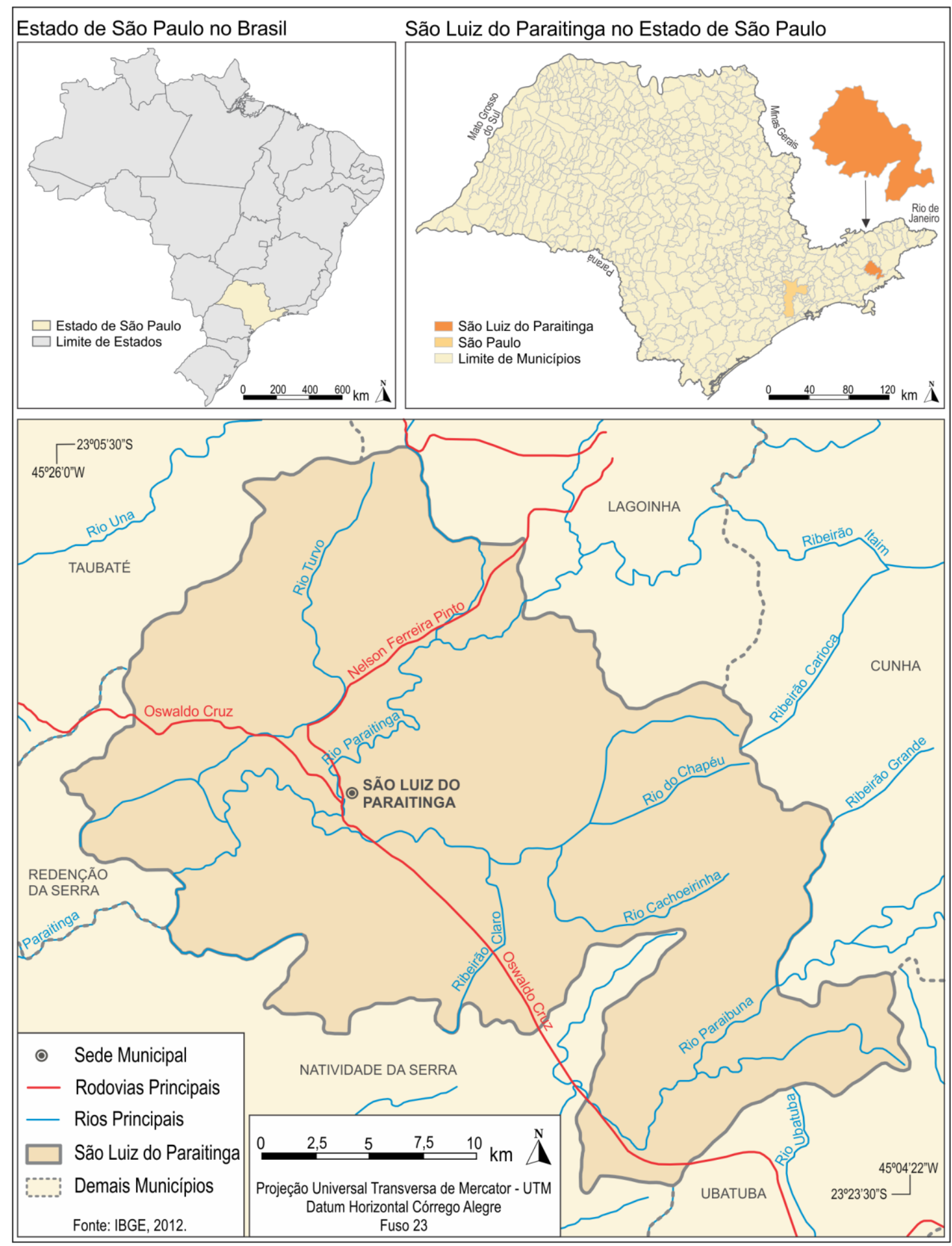

Figura 20 - São Luiz do Paraitinga (SP): localização 


\subsection{Breve histórico}

O Vale do Paraíba se afirmou, a partir do século XVII, como uma área de passagem e de circulação e passou a fazer parte dos roteiros dos comerciantes do período. Várias frentes foram descerradas, dirigindo-se ao litoral norte e ao sopé da Serra da Mantiqueira (PETRONE, 1959).

No século XVIII a colonização do Vale do Paraíba evoluiu e se tornou uma rota importante de escoamento da produção de ouro extraído da Capitania de Minas Gerais. O principal destino das mercadorias manufaturadas advindas de São Paulo, Minas Gerais e Rio de Janeiro tinham como destino o porto de Paraty. Mas, aos poucos, o porto de Ubatuba surgiu como importante setor de escoamento de mercancias, tornando a passagem das tropas por São Luiz do Paraitinga praticamente obrigatória, transformando a cidade em um relevante polo de provimento de gêneros de primeira necessidade.

A organização demográfica social, bem como as relações econômicas da região, estavam ligadas à política administrativa da Metrópole Portuguesa. Baseado nessa política, o governo português interessado em metais, pedras preciosas e índios, incentivou e intensificou a atividade dos bandeirantes. Essa atividade contribuiu para que novos caminhos que levavam ao sertão fossem abertos. Diante disso, a região, no final do século XVIII, era a mais povoada da Capitania de São Paulo (PETRONE, 1959).

A forma do traçado urbano de São Luiz do Paraitinga, situado em um dos meandros do Rio Paraitinga, decorre, no entanto, da época do estabelecimento das rotas de escoamento do ouro explorado na capitania de Minas Gerais. Dessa forma, a criação e desenvolvimento de São Luiz estão diretamente relacionados à sua localização.

São Luiz do Paraitinga teve sua fundação oficial em 08 de maio de 1769, apesar de suas terras terem sido ocupadas um século antes. Em janeiro de 1773, foi elevada à Vila. Possuía, então, 52 casas e muitas outras em construção, e em 1774 um censo informava a presença de 800 pessoas (CORREA, 2010).

A Vila, de início, centralizava-se na agricultura de subsistência, concentrada no feijão, mandioca, milho e cana de açúcar. No decorrer do século XIX a região do Vale do Paraíba começou a sofrer profundas transformações, onde antes dominava o cultivo do açúcar passou, cada vez mais, a ter no cultivo do café a sua sustentação econômica.

Neste século, o advento da cultura cafeeira trouxe enormes benefícios para o Vale do Paraíba. A cafeicultura tornou-se a atividade mais importante da região, um período de 
magnificência que durou aproximadamente até 1918 (PETRONE, 1959). De acordo com Correa (2010, p. 21):

Em 1817 foi fundada a primeira fazenda cafeeira da região. [...] A partir de 1830 se constatara uma monocultura cafeeira, que influenciou mudanças na economia e nos costumes da sociedade com a singela introdução do capitalismo e consumismo à região.

Pelo Vale do Paraíba, o café penetrava no Estado de São Paulo e logo todo o vale se cobria da rubiácea. O ouro verde, no aspecto social, foi responsável pela formação de uma nova configuração, por introduzir uma nova classe política (deu prestígio e poder político à região) e uma nova classe econômica representada pelos ambiciosos barões de café.

Lemos (1999, apud SANTOS, 2006, p. 138) destaca ao afirmar a importância da economia cafeeira na transformação sócio-espacial do Vale do Paraíba:

[...] o café foi um verdadeiro 'divisor de águas' na vida cultural em geral e na civilização material, em particular de São Paulo. [...] Antes, a colônia era pobre e caipira; depois, a província riquíssima. [...] O café alterou para sempre as relações necessárias até então vigentes entre o saber-fazer local e os recursos que o meio ambiente oferecia.

Porém, mesmo São Luiz do Paraitinga fazendo parte desse contexto, por estar localizada às margens do principal corredor de produção cafeeira do país à época, não passou, de forma aguçada, por esse processo de substituição de cultivo. Em São Luiz do Paraitinga não ocorreu, portanto, uma total substituição da policultura pelo café. Nesse sentido, é importante salientar que em São Luiz do Paraitinga a riqueza gerada pelo café não se concentrou de maneira tão intensa, como ocorreu em outros municípios da região. Porém, não se pode desprezar a importância do café como responsável pela (re)produção do espaço, mas isso se deu de maneira indireta. Foi a sua vocação de entreposto comercial, ora de tropas que transportavam ouro, ora de tropas que transportavam café, e de abastecimento de gêneros alimentícios que estimulou a fundação e expansão desse núcleo. Para Santos (2006), o tropeirismo tem origem a partir de uma conjuntura social, geográfica e política, o que o torna não apenas uma atividade econômica, mas sim socioeconômica pelo viver específico que proporciona e pelo impacto sobre o território, estimulando a fundação de arraiais e vilas.

O autor supracitado reforça a importância de São Luiz do Paraitinga como entreposto comercial, qualificando a rota que passava por esse município como sendo a segunda mais movimentada à época. Ressalta-se que muito do patrimônio cultural remanescente é fruto do período econômico do ciclo do café, e, hoje, a população local ainda exalta a suposta riqueza proporcionada por ele. 
Porém, é importante salientar que a cidade foi fundada em decorrência da atividade tropeira e é essa a atividade que, mesmo no momento áureo do café no Vale do Paraíba, fez com que São Luiz do Paraitinga vivesse sua época de maior prosperidade.

Esse período foi de grande transformação para a cidade, deu-lhe uma nova perspectiva econômica e modificou sua estrutura física. A Vila, essencialmente rural, viu surgir seus primeiros melhoramentos como calçamentos de ruas, atividades de lazer e teatrais que lhe forneciam ares de zona urbana. A residência mais importante dos fazendeiros passou a ser a casa da cidade, e só se dirigiam à fazenda no momento da colheita (SANTOS, 2006). Casas imponentes para a época eram construídas. Na sede das fazendas, as casas de taipa foram substituídas por casarões amplos, muitos deles assobradados. São construções que apresentam elementos utilizados nas edificações mineiras e outras, baseadas no neoclássico carioca.

De acordo com a tipificação das obras do patrimônio de São Luiz do Paraitinga feita pelo CONDEPHAAT (1982, p. 14), a arquitetura existente no município é definida com:

[...] forte presença mineira, seja em relação aos elementos formais, seja na acomodação das edificações à topografia irregular, juntavam-se vestígios do neo-clássico, em largo uso no Rio de Janeiro, reflexo da presença da Corte, da experiência dos engenhos da baixada fluminense e da taipa de pilão, característica marcante da região paulista.

É dessa época, muito da fisionomia que, atualmente, apresenta a área central da cidade, como mostra a figura 21. Possui características típicas do século XIX, do passado colonial que ainda são preservadas e constitui o patrimônio cultural nacional, que hoje atrai tantos turistas.

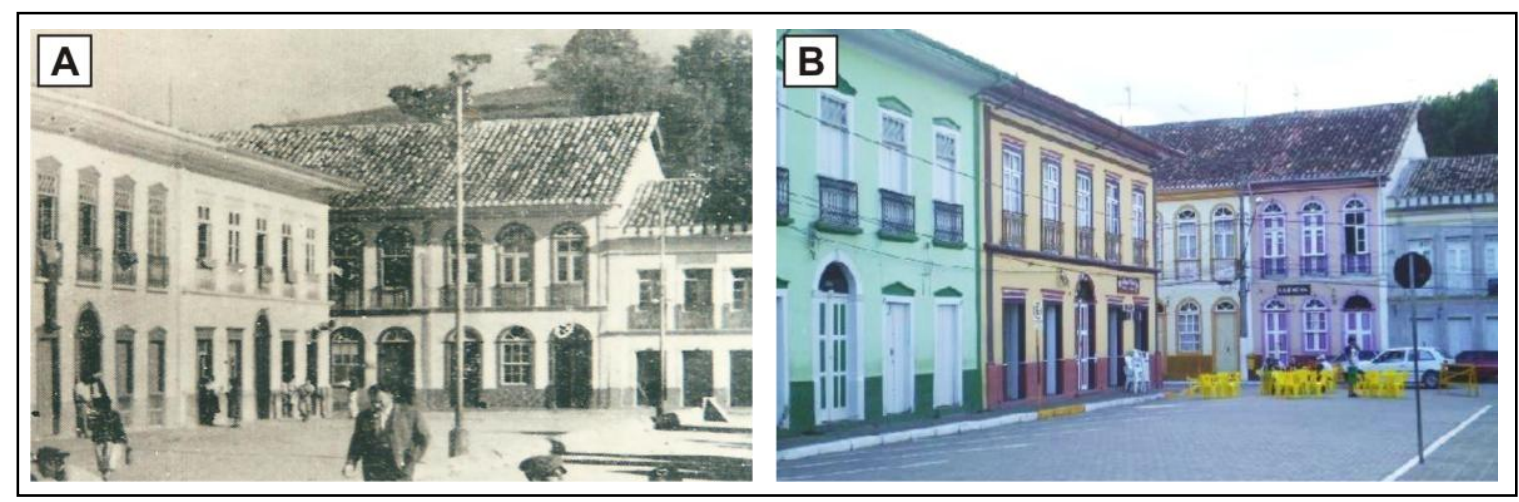

Figura 21 - Casarios situados ao redor da Praça Oswaldo Cruz em 1930 e 2009 Foto A: acervo Juventino Galhardo; Foto B: Felipe Costa.

Documentos da época informam que a riqueza da localidade também era marcada pela expressão da cultura caipira que confere a São Luiz do Paraitinga um legado cultural singular 
no território paulista, abrangendo os saberes e fazeres, as manifestações religiosas e profanas, as músicas e as danças (IPHAN, 2010).

Porém, no início do século XX inicia-se a queda da cultura cafeeira. E, apesar de São Luiz do Paraitinga não ter investido apenas em café, sofreu muito com a o empobrecimento do mesmo na região. A grande queda na cultura de café do município deu-se entre os anos de 1912 e 1922. A decadência continuou até que a grande crise econômica de 1929 rematou, em definitivo, a pequena produção cafeeira em São Luiz do Paraitinga, e os poucos cafezais que ainda restaram nas demais cidades da região foram destruídos gradativamente (PETRONE, 1959).

Após o declínio do café, São Luiz do Paraitinga viu na pecuária leiteira sua maior fonte de economia. E tal fato foi ainda mais estimulado com o advindo da indústria dos laticínios Vigor para a cidade. Isso ocorreu no ano de 1953, período no qual a população, num crescente, atinge a cifra de 15 mil habitantes. No entanto, a modernização se tornou essencial para maior e melhor produção do leite. Havia a concorrência e altos investimentos nesse setor se fizeram necessários. Os produtores rurais, principalmente os pequenos produtores, não conseguiram suportar tamanha carga. Desse modo, a decadência, pelos anos de 1980, na fase da pecuária foi inevitável (PEREIRA, 2012).

Um depoimento feito pelo geógrafo Aziz Ab'Saber (2007, p. 16-17), confirma o fato:

[...] o ciclo do café foi terminando e os fazendeiros mudando para suas casas na cidade, as fazendas ficaram sem recursos, os roceiros começam a cultivar para subsistência e levam seus produtos para vender no "mercadão" de São Luiz. Em troca, adquirem as coisas que não têm - querosene, açúcar, sal - e vão pra missa $[\ldots]$.

Com o empobrecimento do homem do campo não havia quase nada a se fazer na zona rural nesses idos de 1980. Dessa maneira, houve uma transferência maciça de pessoas para a cidade, um êxodo rural intenso. A urbe, que contava com 1.395 habitantes em 1950, se viu habitada por 6.145 pessoas, em 2000. Nessa mesma época, tem-se, também, a ocupação do Morro do Cruzeiro de maneira bastante desordenada (PEREIRA, 2012).

O município se situava relativamente afastado dos principais eixos viários da região, a rodovia Presidente Dutra (BR 116/SP 60), e a ferrovia Central do Brasil (originalmente, Estrada de Ferro D. Pedro, do final do século XIX). De modo, esta região ficou esquecida pela dinâmica de desenvolvimento econômico do estado. Esse isolamento da política econômica regional e sua redução econômica às relações locais de produção agrícola, por outro lado, preservaram o patrimônio cultural do lugar. 
A cidade de São Luiz do Paraitinga foi reconhecida como Patrimônio Cultural do Estado de São Paulo pelo CONDEPHAAT, em 1982. Foi o impulso dado para que a população, ainda que de maneira não muito intensa, voltasse a crescer, pois o turismo iniciava sua atividade como forma de expandir a economia. Muitas casas (moradias) bem como pequenos e médios estabelecimentos comerciais, mantêm o conjunto tombado com a mesma forma, igual estrutura e semelhantes fachadas como antigamente. De acordo com Pereira (2012, p.57), baseado nos estudos do IPHAN (2010), a cidade está inspirada em localidades como Ouro Preto, Olinda e Recife, e "passa a dar ênfase às suas manifestações populares como o carnaval de rua e os festejos religiosos, tudo dentro de um cenário urbano tradicional tombado, imerso numa paisagem natural em regeneração como atrativo".

Apesar deste contexto histórico e da acelerada consolidação do meio urbano, não se pode deixar de abalizar os colossais espaços rurais e as fazendas históricas como atrativos turísticos. Não menos importante, devido a extensão do território e aspectos geomorfológicos favoráveis, o turismo em áreas naturais igualmente tem se firmado de modo expressivo no município.

Devido suas características especiais à promoção do turismo, como infraestrutura, atrativos culturais, naturais ou recreativos, em julho de 2002, por meio da lei ${ }^{\circ} 11.197$, São Luiz do Paraitinga recebeu o título de Estância Turística. Dessa forma, o município passou a receber uma verba anual oriunda do Departamento de Apoio ao Desenvolvimento das Estâncias (DADE), órgão ligado a Secretaria da Cultura do Estado de São Paulo.

\subsubsection{Patrimônio cultural em risco}

O município de São Luiz do Paraitinga foi acometido, no final do ano de 2009, por chuvas torrenciais que afetaram de maneira significativa a vida dos moradores. Como consequência, muitos tiveram que abandonar suas casas. As águas destruíram, também, grande parte do acervo patrimonial da cidade (figura 22).

No último dia de dezembro deste mesmo ano, foi registrada queda de chuvas em um nível esperado para todo o mês em São Luiz do Paraitinga. As terras, já encharcadas pelas chuvas anteriores, não conseguiram absorver o grande volume de água. Por conta disso, toda a água desaguou no Rio Paraitinga que, saturado, transbordou. Foi tanta a precipitação

pluviométrica que na cidade de São Luiz, o rio Paraitinga subiu cerca de 12 metros, provocando consideráveis transtornos na história da cidade, a qual teve seu centro histórico 
arrasado pela maior cheia já registrada do rio Paraitinga (Jornal da Reconstrução, março de 2010).

Vários prédios públicos da urbe foram prejudicados. A sede da municipalidade, ligada por dois prédios - sendo um casarão histórico do centro e uma propriedade atual que margeia o rio - sofreu abalos na parte da frente do edifício. A biblioteca municipal também ruiu, e com ela todos os livros foram perdidos. Mais da metade da centenária Igreja Matriz desabou. Outra igreja centenária, a mais antiga da cidade, a Capela das Mercês, também foi atingida pela catástrofe. Grande parte da casa de Oswaldo Cruz, que não foi atingida pela enchente, desmoronou meses depois, ainda em consequência das chuvas.

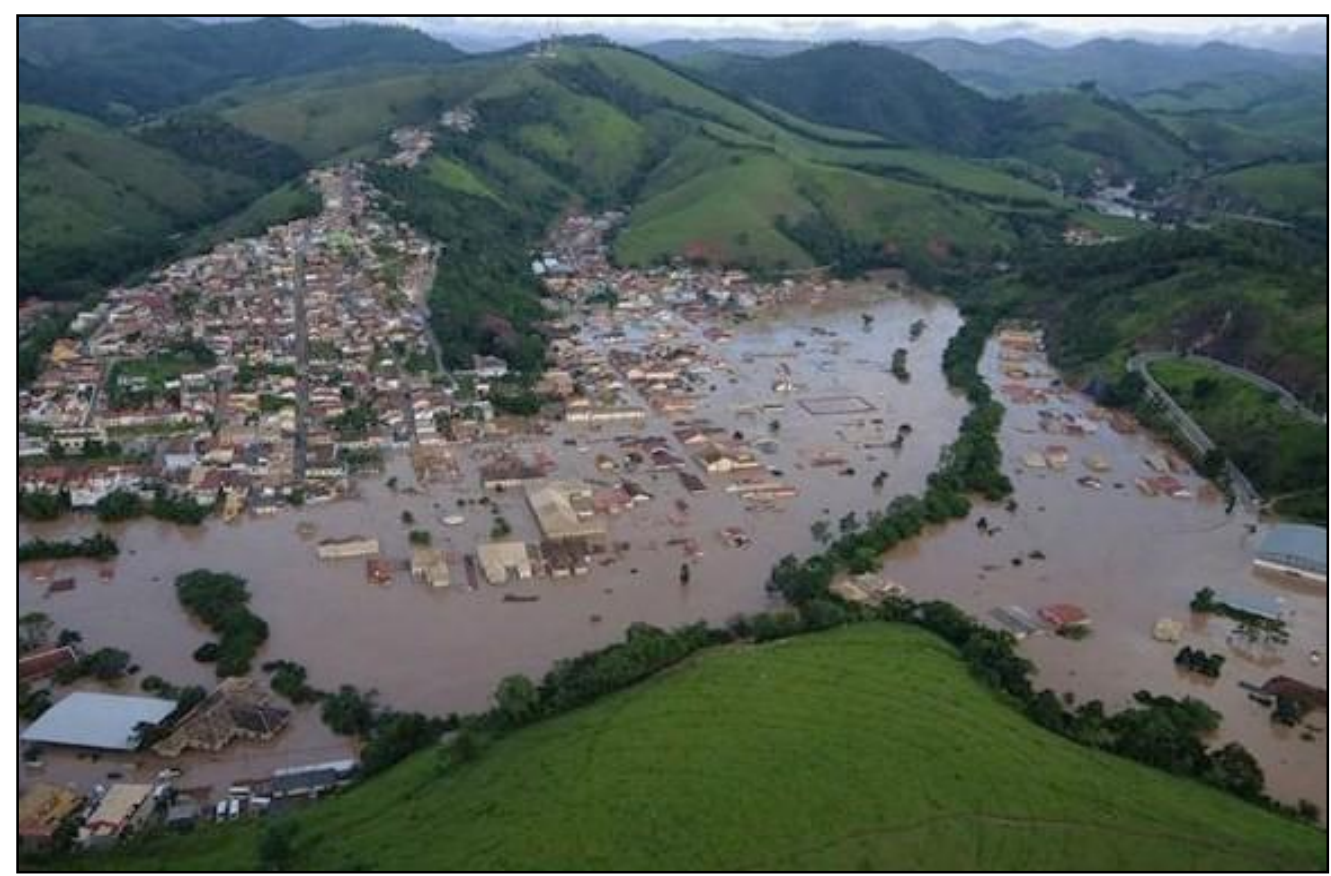

Figura 22 - Vista aérea da enchente em 2010

Foto: Lucas Lacaz Ruiz

Destaca-se que as avarias decorrentes dessa última inundação não podem ser encaradas apenas como prejuízos materiais, mas, também, como perdas da memória de uma comunidade, visto que, entre os bens arruinados estão os principais sustentáculos da identidade luizense. O fenômeno climático, no entanto, despertou a solidariedade da população local e de todo o país. Além disso, obrigou o poder público a olhar mais atentamente à cidade, que cresceu cercada de rios e morros.

Apesar do transtorno, a população, frente à sua própria sobrevivência, reagiu de maneira positiva. Mesmo a alto custo psicológico e financeiro, a maior parte dos munícipes conseguiu voltar para casa e retomar suas vidas. O comércio, ainda debilitado, abriu outra vez 
suas portas. O calendário festivo foi retomado aos poucos, mesmo com muita coisa ainda a ser feita e restaurada.

Diante dos problemas gerados pela enchente, a cidade conseguiu apoio e rapidamente iniciou a reconstrução. No ano de 2010, a UNESP - Universidade do Estado de São Paulo (2010) conduziu uma pesquisa ${ }^{28}$ para a qual foram entrevistados 374 turistas que visitaram São Luiz durante a festa do Divino Espírito Santo. Segundo os resultados, o município já apresentava infraestrutura suficiente para voltar a receber os visitantes. Satisfeitos, $99 \%$ dos entrevistados, com idades entre 20 e 70 anos, afirmaram que pretendiam retornar à cidade. Cerca de dois terços deles aprovaram a velocidade da reconstrução da cidade, contrariando a imagem, pois muitos prédios ainda estavam em fase de reconstrução.

Hoje, todos os eventos festivos foram retomados e 95\% dos edifícios arruinados pela enchente foram recuperados, mas ainda falta finalizar o principal patrimônio cultural arquitetônico da cidade: a Igreja Matriz

\subsection{Demografia, aspectos socioeconômicos e infraestruturas}

Para um desenvolvimento eficiente do turismo, deve ser adotada uma série de medidas de (re)estruturação do destino, como os equipamentos básicos e de apoio, a infraestrutura, os atrativos turísticos, os serviços e os produtos, além de várias atividades em todos os níveis de decisões e operações referentes à atividade. $\mathrm{O}$ fomento ao turismo bem planejado é uma etapa desse processo no qual deve haver uma combinação de considerações políticas, econômicas, sociais e ambientais, envolvendo, de forma ativa, todos os atores. Torna-se necessário, no entanto, analisar dados e informações a respeito dos aspectos demográficos, econômicos, infraestruturais, entre outros os quais se julgam pertinentes ao estudo do turismo, no município de São Luiz do Paraitinga.

Quando se trata de valores demográficos, ressalta-se que no município houve um fator migratório bastante expressivo. São Luiz do Paraitinga chegou a ter 29.535 habitantes no ano de 1900 e 20.367 na década de 1920, população essa que foi reduzida para 14.547 pessoas em 1950 após a decadência do café e, posteriormente, diminuiu para 10.397 em 2010, com

\footnotetext{
${ }^{28}$ A pesquisa foi conduzida pelos professores pesquisadores Arminda Campos, Eduardo Coelho e Maurício Delamaro. É resultado de uma parceria da prefeitura com a Unesp. Devido a ocorrência da enchente, a UNESP e a Prefeitura da cidade intensificaram suas parcerias. Foi criado o "Programa UNESP para o Desenvolvimento Sustentável de São Luiz do Paraitinga" que é composto por 10 frentes de atuação e mobiliza docentes e estudantes de 8 campus da universidade.
} 
densidade demográfica de 16,85 hab/ $\mathrm{km}^{2}$ (gráfico 04). Dados estatísticos apontam que, em comparativo com o Estado de São Paulo, a população de São Luiz do Paraitinga teve um pequeno decréscimo na ultima década. Enquanto o Estado apresentou crescimento populacional de 1,09\% ao ano, o município revelou uma taxa geométrica negativa (2000/2010) de crescimento anual da população, de - 0,03\% (IBGE, 2010).

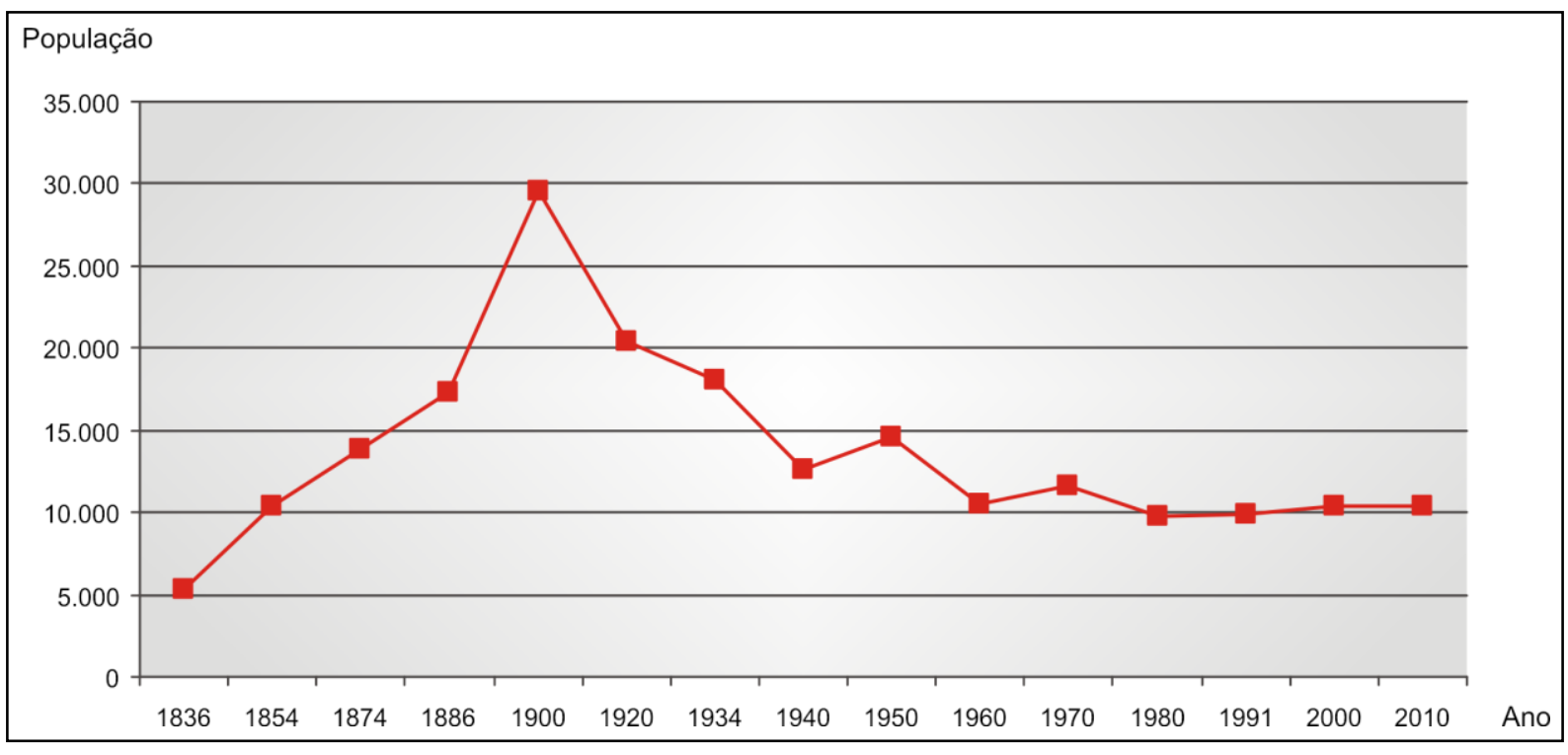

Gráfico 04 - Evolução da população, 1836 a $2010^{29}$

Fonte: PETRONE (1959); IBGE: Censo Demográfico e Contagem Populacional

O decréscimo populacional entre os anos de 1950 a 1980 foi reflexo de uma economia urbana pouco diversificada e da falência das atividades produtivas do campo, o que obrigou seus habitantes a deslocarem-se para cidades maiores em busca de novas oportunidades de trabalho. O êxodo do município ocorre em direção a outras cidades do Vale do Paraíba, em especial para Taubaté e São José dos Campos, industrializadas e com mais oportunidades de emprego.

A partir de 1980, os atos migratórios também se intensificaram para a área urbana do próprio município. Nessa época, a cidade possuía 9.743 mil habitantes, 3.947 mil eram de origem urbana e 5.796 rural. Um decênio depois, havia um equilíbrio entre o número de habitantes urbanos e rurais e, nas últimas duas décadas, percebe-se um número mais elevado na população urbana (gráfico 05).

A população rural, desde o fim da cafeicultura no início do século $\mathrm{XX}$, vem diminuindo de forma gradativa, consequentemente, há um aumento na taxa de urbanização

\footnotetext{
${ }^{29}$ Os módulos do eixo horizontal não estão proporcionais aos intervalos de tempo entre os de 1836 a 1934 . A metodologia de contagem deste período histórico é desconhecida.
} 
que saltou de 40,51\% em 1980 para 59,44\% em 2010 (IBGE, 2010). Observa-se, então, uma inversão nas taxas de urbanização e ruralização (gráfico 06).

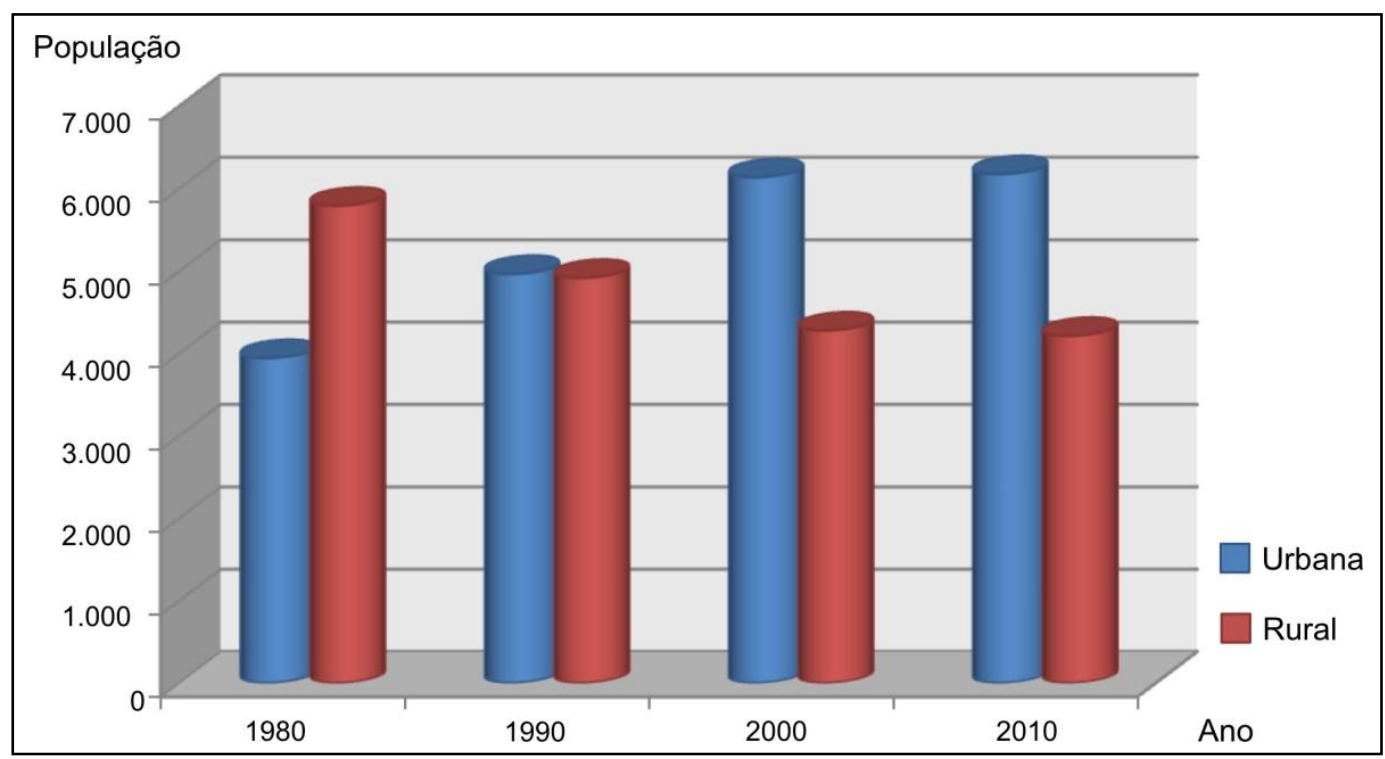

Gráfico 05 - População rural e urbana, 1980, 1990, 2000 e 2010 Fonte: IBGE, Censos Demográficos.

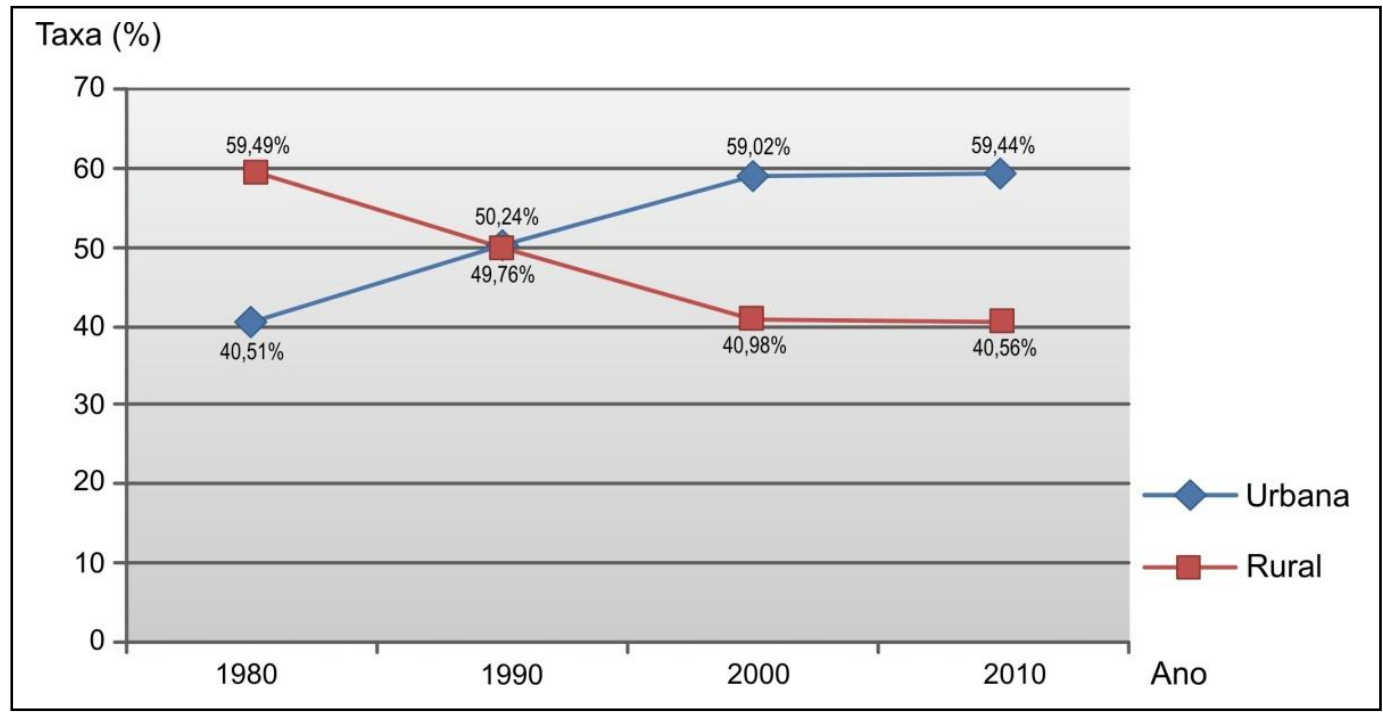

Gráfico 06 - Taxa de urbanização e ruralização, 1980, 1990, 2000 e 2010 Fonte: IBGE, Censos Demográficos.

É sabido que este processo de expansão urbana tende a se acentuar, o que pode se tornar mais complexo com a afirmação das atividades do turismo, novo polo de desenvolvimento econômico do local, transformando a cidade, ainda mais, num foco de atração populacional. 
De acordo com o censo demográfico de 2010 (IBGE), o rendimento médio ${ }^{30}$ da população no município é de $\mathrm{R} \$ 669,87$ e a distribuição de empregos formais com vínculo empregatício, segundo dados disponibilizados pelo Ministério do Trabalho e Emprego (MTE), somam 1.581 empregos no ano de 2011.

Torna-se relevante, no entanto, ampliar o período de análise a fim de aprofundar os conhecimentos da dinâmica econômica do município e compreender os atuais resultados. Apresentam-se, na tabela 01, os números de estabelecimentos instalados e empregos formais a cada quinquênio, desde o ano de 1996.

Tabela 01 - Estabelecimentos e empregos formais por setor de atividade, $1996,2001,2006$ e 2011

\begin{tabular}{|c|c|c|c|c|c|c|c|c|}
\hline Ano & \multicolumn{2}{|c|}{1996} & \multicolumn{2}{c|}{ 2001 } & \multicolumn{2}{c|}{ 2006 } & \multicolumn{2}{c|}{2011} \\
\hline Setor & Estab. & Emp. & Estab. & Emp. & Estab. & Emp. & Estab. & Emp. \\
\hline Indústria & 18 & 89 & 12 & 87 & 14 & 82 & 20 & 118 \\
Comércio & 41 & 68 & 61 & 148 & 70 & 272 & 73 & 311 \\
Serviço & 29 & 395 & 49 & 418 & 61 & 901 & 79 & 817 \\
Agropecuária & 85 & 165 & 129 & 255 & 130 & 320 & 149 & 330 \\
\hline Total & $\mathbf{1 7 4}$ & $\mathbf{7 1 7}$ & $\mathbf{2 5 1}$ & $\mathbf{9 0 8}$ & $\mathbf{2 7 5}$ & $\mathbf{1 . 5 7 5}$ & $\mathbf{3 2 1}$ & $\mathbf{1 . 5 7 6}$ \\
\hline
\end{tabular}

Fonte: Relação Anual de Informações Sociais - RAIS/Ministério de Trabalho e Emprego - MTE

No município de São Luiz do Paraitinga, a função industrial é incipiente, existindo apenas acanhadas oficinas de ferreiros, carpinteiros, seleiros e pequenas indústrias. Entre as indústrias destacam-se a de molho de tomate e condimentos, de farinha de milho, panificação e alguns alambiques que produzem aguardente de forma artesanal, na sua maioria. Há poucos estabelecimentos industriais na cidade, perfazendo um total de 20 estabelecimentos em 2011. No geral, as indústrias oferecem um número reduzido de empregos, a maioria deles sem qualificação.

Apesar do decréscimo populacional, constata-se que a função comercial aumentou. A participação empregatícia foi de 19,6\% em 2011. Destaca-se neste subsetor o comércio de mercadorias em geral, com predominância de produtos alimentícios e de ferragens, madeira e materiais de construção, que, juntos, representam quase $60 \%$ dos empregados que atuam nas atividades comerciais. Uma característica importante do comércio de São Luiz do Paraitinga é

\footnotetext{
${ }^{30}$ Valor do rendimento nominal médio mensal per capita dos domicílios particulares permanentes nas áreas urbanas e rurais.
} 
a presença do trabalho familiar. Pai, mãe, filhos e os parentes mais próximos ocupam muitos destes postos de trabalho, em pequenos comércios, pertencentes há anos a mesma família.

Quando se trata da agricultura e pecuária, é possível observar que, apesar perder importância econômica após os anos 50 devido a industrialização, os últimos 15 anos tem mostrado pequeno crescimento no setor, isso porque a zona rural, hoje, é constituída por micro produtores, pecuária bovina e plantio de eucalipto. A agropecuária, ainda, é bastante relevante na cidade. Sua participação de 20,9\% no total de empregos formais em 2011 é significante.

Nota-se, porém, que a economia atual de São Luiz do Paraitinga converge principalmente para as atividades voltadas ao setor terciário, em especial, o de serviço. Este abarca grande parte da empregabilidade formal no município e aponta um crescimento expressivo, em especial, a partir de 2006, cerca de 86,5\% em relação a 2001. Em 2011 o setor de serviço empregava 817 pessoas. A maior parte dos empregos formais das atividades de serviço $(26,5 \%)$ concentra-se no setor de produtos alimentícios e bebidas, representado em grande parte por restaurantes, bares e botequins.

Torna-se relevante, outrossim, considerar que os empregos informais, no atual cenário econômico brasileiro, representam uma grande parte da população ativa na composição da dinâmica econômica de qualquer lugar e esses dados não são mensurados, o que pode promover distorções na análise.

É pertinente firmar, nesta pesquisa, que nas atividades produtivas do município, em relação ao valor adicionado do Produto Interno Bruto (PIB), o setor de serviço nos últimos 10 anos sempre prevaleceu no topo da atual economia de São Luiz do Paraitinga. O gráfico 7 aponta que no último decênio o PIB agropastoril e industrial manteve um patamar instável com algumas elevações paliativas até 2010. O setor de serviços já mostrava um valor adicionado relevante no início da década passada e intensificou a atividade econômica no município. Apesar da queda sofrida no ano de 2007 devido a crise mundial, o setor de serviço recuperou-se e cresceu $18,6 \%$ em 2010. 


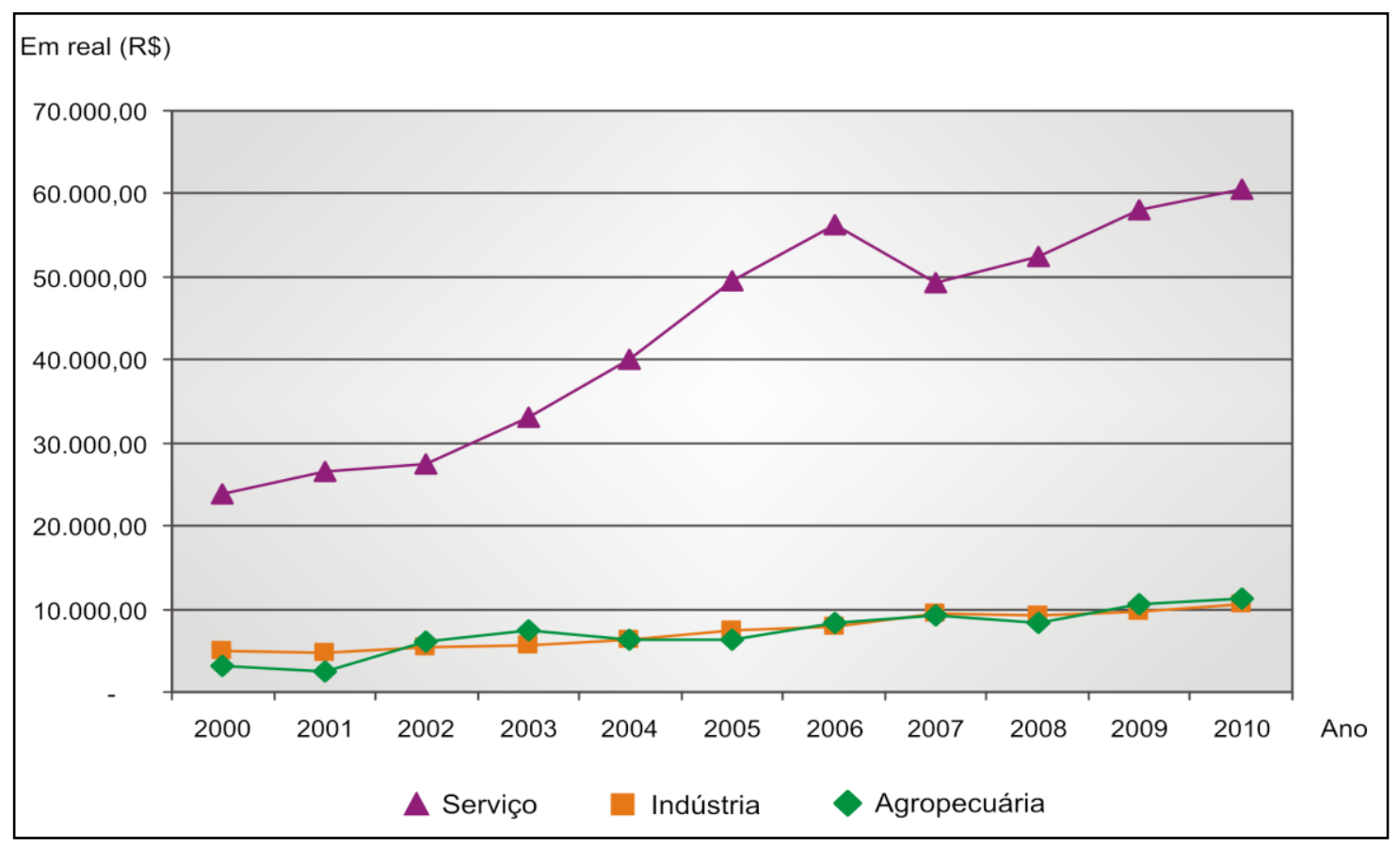

Gráfico 07 - Produto Interno Bruto ${ }^{31}$ da Agropecuária, Indústria e Serviços ${ }^{32}, 2000$ à 2010 Fonte: IBGE, 2001 à 2011

Diversas são as atividades relacionadas ao setor de serviço, entre as quais se encontra o turismo, que se tem revelado importante para o no município. São Luiz do Paraitinga se insere em uma categoria representativa que oferece grande potencial de atrativos turísticos com pouco recurso financeiro. Assim, o turismo, hoje, é uma das atividades que registra acentuado crescimento financeiro, o que conduziu o município a se integrar nessa tendência.

O turismo em São Luiz do Paraitinga se destaca devido a propensão de desenvolvimento da atividade turística iniciada no final de década de 1990 na cidade. Com o objetivo de transformar São Luiz do Paraitinga em Estância Turística, fato consumado em 2002, a prefeitura incentivou, por meio de propagandas, a expansão desse setor. Iniciou-se, dessa maneira, uma nova atividade econômica que vem se firmando na cidade.

É importante destacar que para a realização da atividade turística, é necessário que o lugar, o espaço turístico, possua infraestrutura capaz de atender a população excedente, que é sazonal e chega a números consideráveis. Esta demanda requer um esforço coletivo, comprometimento e envolvimento da população local, além de planejamento e intervenções pontuais, como a ampliação do número de sanitários, atendentes da área de saúde, hospedagens, entre outros.

\footnotetext{
${ }^{31}$ Valor adicionado bruto a preços correntes (mil reais).

${ }^{32}$ Inclusive serviços de administração, saúde e educação públicas e seguridade social.
} 
Em São Luiz do Paraitinga, a atividade turística fez com que aumentasse de maneira expressiva o número de estabelecimentos hoteleiros e outros serviços voltados para alimentação e bebidas, proporcionando maior oferta de trabalho. Porém, alguns meios de hospedagem, bem como restaurantes e bares vivem na clandestinidade ou estão registrados em outras categorias como comércio varejista de produtos alimentícios. Assim, o real vínculo empregatício das pessoas que prestam serviços no setor de hotelaria e turismo fica camuflado ou não condiz com a realidade.

Segundo os dados do MTE, em 2011, existiam na cidade apenas oito hotéis ou outros tipos de alojamentos e 17 pessoas empregadas. Neste mesmo ano, ainda segundo o MTE, havia 17 bares, restaurantes ou similares e 87 pessoas empregadas neste subsetor. Tais números não expressam a realidade do local. Vê-se, de forma efetiva, um número maior de trabalhadores, pontos comerciais e prestadores de serviço do que o registrado pelo MTE.

Diante deste contexto, foi necessário a realização de uma pesquisa em campo. Levantou-se uma listagem de meios de hospedagens por intermédio de informações contidas na internet e guias turísticos, além de dados fornecidos pelos proprietários. O resultado desta pesquisa aponta o tipo e número de estabelecimentos hoteleiros por ano de instalação, conforme apresentado no gráfico 08.

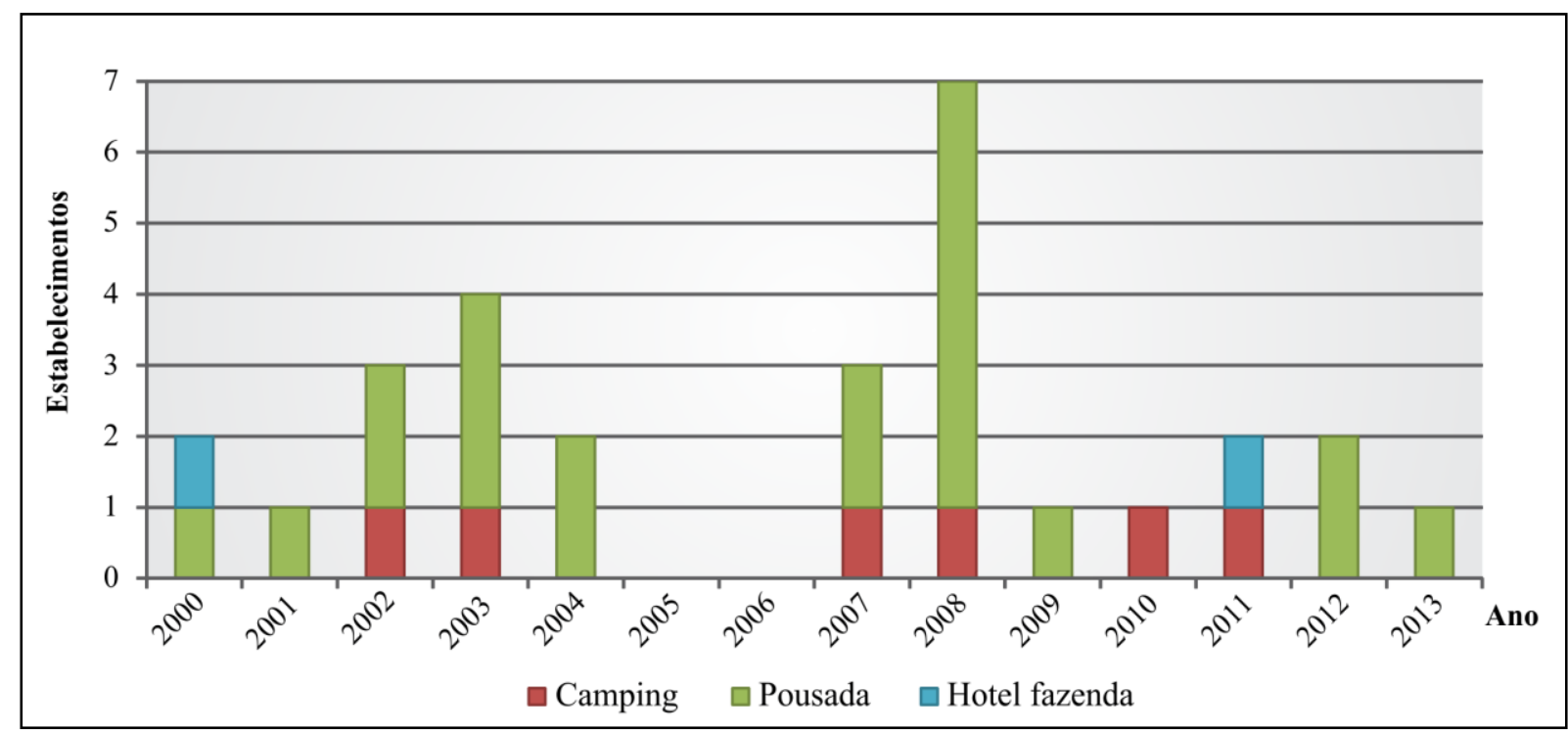

Gráfico 08 - Tipos e número de estabelecimentos hoteleiros instalados, 2000 à 2013 Fonte: Pesquisa de campo realizada pela autora, 2013

No município há 29 meios de hospedagens de pequeno porte e $72,4 \%$ deles são pousadas. Todos os estabelecimentos existentes foram "oficialmente" instalados a partir do ano 2000 e alguns funcionam apenas durante períodos festivos e feriados prolongados. 
Além dos meios de hospedagens, a boa condição da malha rodoviária desperta o interesse dos visitantes. A principal rodovia de acesso à cidade é a SP 125 - Rodovia Oswaldo Cruz - que liga Taubaté a Ubatuba. É possível ingressar nesta rodovia através da Rodovia Presidente Dutra e Rio-Santos. A Rodovia Carvalho Pinto, apesar de desembocar na Rodovia Presidente Dutra próxima a cidade de Taubaté, também é uma escolha vantajosa (figura 23). Há, outrossim, algumas rodovias secundárias. A principal delas é a rodovia Nelson Ferreira Pinto, que conecta São Luiz do Paraitinga com o município de Lagoinha.

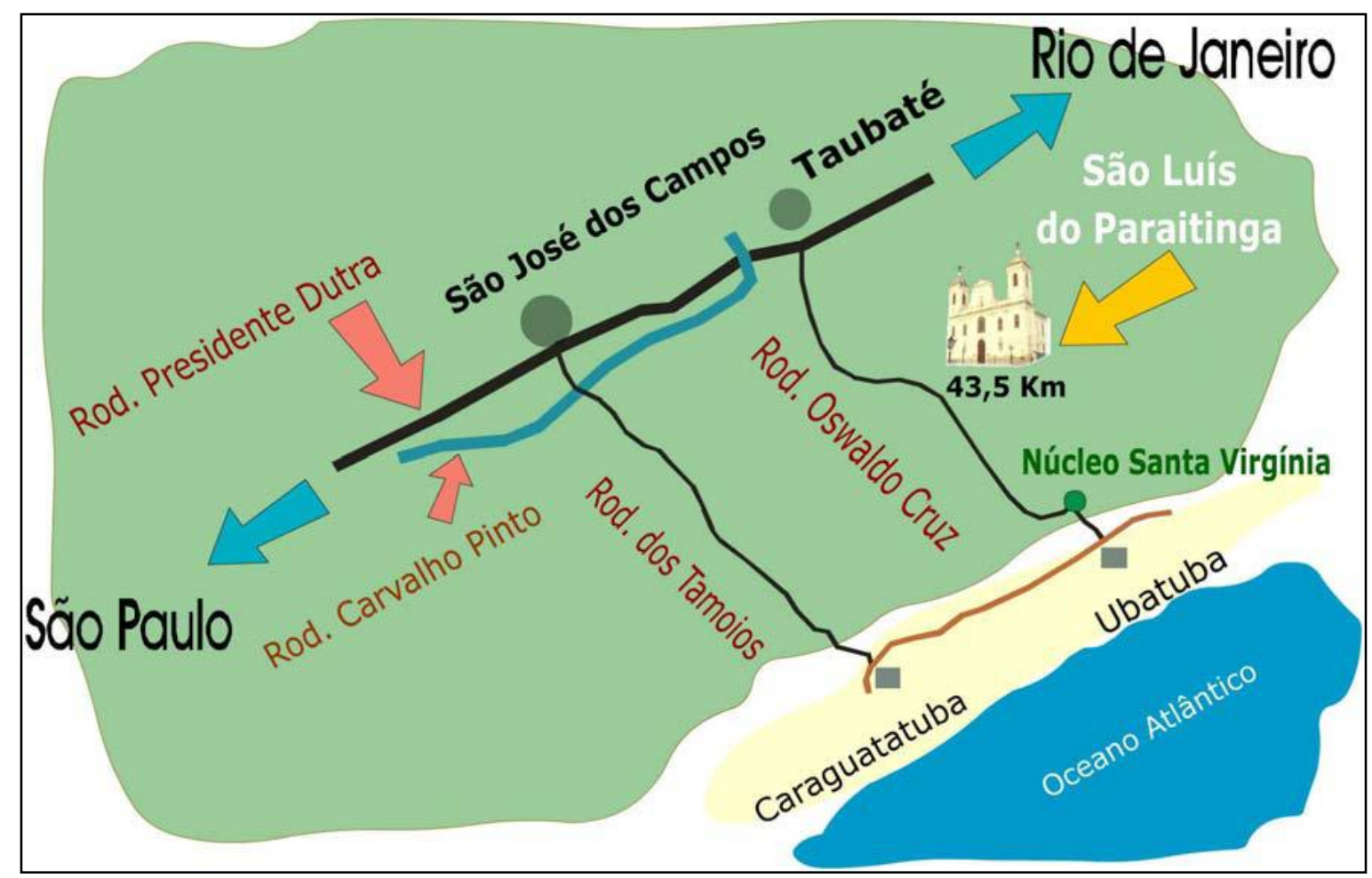

Figura 23 - Croqui rodoviário e acessibilidade

Fonte: 〈http://www.paraitinga.com.br/slparaitinga/A_Cidade/Como_Chegar>. Acesso em 03 de janeiro de 2012

No município não existem acessos em massa por meio de transportes aéreos, aquáticos ou férreos. Há veículos coletivos particulares com destino a Taubaté (oito viagens diárias), Lagoinha (três viagens diárias) e Ubatuba (quatro viagens diárias). O transporte público no município é precário, há poucos ônibus que interligam o centro da cidade com bairros rurais.

É na área urbana de São Luiz do Paraitinga onde se concentra a maior parte da população, economia, patrimônio, atividades turísticas, entre outros, e é composto pelos bairros de Benfica, Alto do Cruzeiro, Praça e Rua Nova. Destaca-se no município o bairro de Catuçaba, localizado a $22 \mathrm{~km}$ do centro da cidade. Este bairro é um antigo distrito que no ano de 1960 foi agregado ao município de São Luiz do Paraitinga. Em Catuçaba vivem, hoje, 
cerca de 800 pessoas e possui um pequeno núcleo urbano com serviço de correios, escola, igreja, posto de saúde, pequeno comércio, etc.

Na zona rural de São Luiz do Paraitinga não há divisão territorial formalizada e é constituída pelos diversos bairros como o Alvarenga, Santa Cruz do Rio Abaixo, Morro Acima, São Roque, Barreiro, Estrada Nova, Ribeirão Claro, Pitangueiras, Sertãozinho, Pimentas, Rio Abaixo, Selado, São Sebastião, Cachoeirinha, Bairrinho, Santa Terezinha, Balsa, Fábrica, Cedro, Chapéu, Paineiras, Oriente, Caetê, Puruba, entre outros.

Com relação à saúde, o município conta com apenas três estabelecimentos (um hospital e dois ambulatórios) (MTE, 2011). Percebe-se que São Luiz do Paraitinga necessita de maiores investimentos na área da saúde, pois sua estrutura é precária, não comportando as necessidades da população local, que agrava, ainda mais, quando se considera o acréscimo da população flutuante, mormente, durante as épocas festivas. Os tratamentos de saúde mais específicos ou graves são direcionados para as clínicas e hospitais da cidade de Taubaté.

No tocante aos aspectos educacionais, a população luizense, conta com o total de 11 centros educacionais: oito escolas de ensino fundamental (1.809 matrículas), duas pré-escolas (126 matrículas) e uma escola de ensino médio (467 matrículas) (IBGE, 2010). No município não há instituição de ensino superior. A ausência do ensino superior incentiva moradores a não prosseguirem os estudos e outros recorrem a faculdades e universidades de cidade como Taubaté, Guaratinguetá e São José dos Campos.

$\mathrm{Na}$ intenção agregar novas informações a este estudo, torna-se pertinente aprofundar e refletir a respeito de diferentes desempenhos econômicos e sociais no município de São Luiz do Paraitinga. Dessa forma, os indicadores do Índice Paulista de Responsabilidade Social (IPRS) sintetizam a situação de cada município do estado de São Paulo no que diz respeito a riqueza, escolaridade e longevidade, e quando combinados geram uma tipologia que classifica os municípios em cinco grupos ${ }^{33}$. Nas edições de 2008 e 2010 do IPRS, São Luís do Paraitinga classificou-se no Grupo 4, que agrega os municípios com baixos níveis de riqueza e com deficiência em um dos indicadores sociais (longevidade ou escolaridade).

Observa-se nos gráficos (9A, 9B, e 9C) que o município teve seus indicadores agregados de riqueza e escolaridade crescentes, em oposição à queda na longevidade. Em termos de dimensões sociais, o escore de longevidade ainda é superior à média do Estado,

\footnotetext{
${ }^{33}$ A metodologia completa pode ser encontrada em: <www.seade.gov.br/projetos/iprs/ajuda/2008/metodologia_2010.pdf>. Acesso em 22 de dezembro de 2012.
} 
mesmo em decadência. $\mathrm{O}$ escore de escolaridade e da riqueza, porém, apesar de crescentes não atingiram a média estadual.

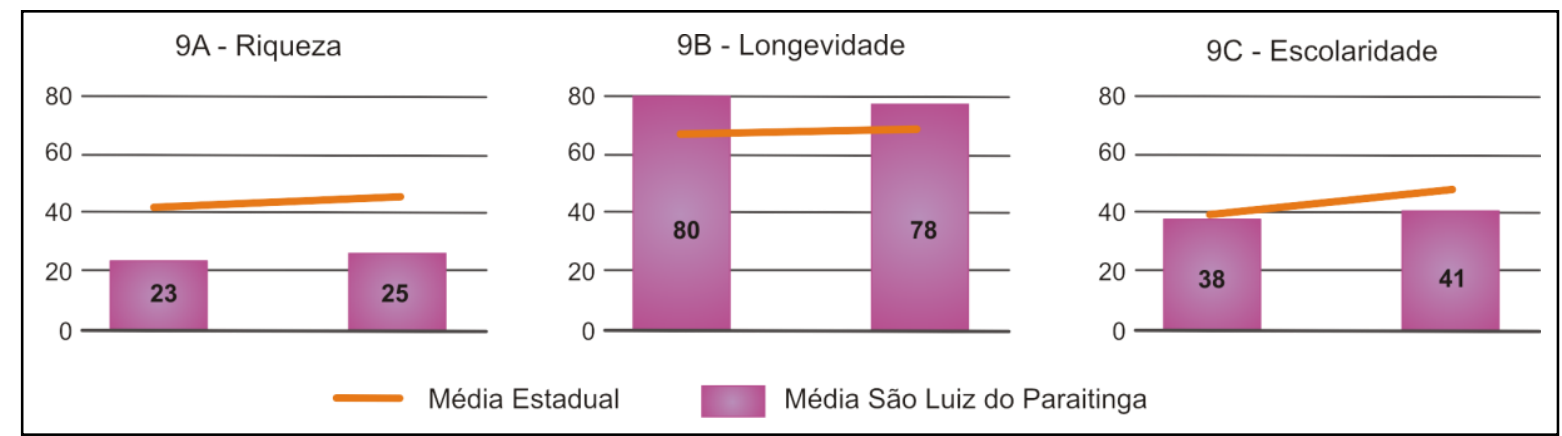

Gráfico 09 - Índice Paulista de Responsabilidade Social (IPRS), 2008 e 2010

Fonte: Fundação SEADE, 2010

Os investimentos públicos nos últimos anos, em especial após a enchente, foram direcionados ao patrimônio arquitetônico por meio de diversas obras de revitalização e reconstrução de edifícios tombados, arruinados pela água. Hoje, São Luiz do Paraitinga busca sua inserção no circuito turístico nacional, tendo como base de apoio seu patrimônio cultural.

A figura a seguir, ilustra um dos principais patrimônios arquitetônico do município, a Capela Nossa Senhora das Mercês em 2003 (antes da enchente - 29A), em janeiro de 2010 (logo após a enchente - 29B) e em novembro de 2012 (obra de reconstrução concluída - 29C).

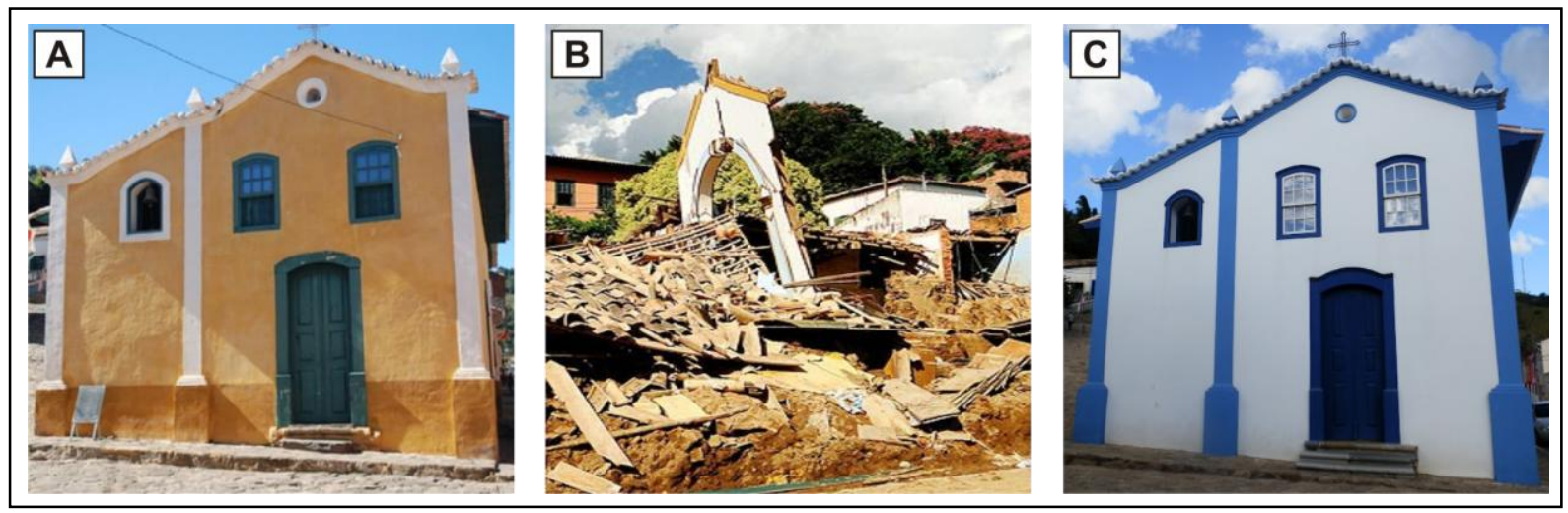

Figura 24 - Capela Nossa Senhora das Mercês, 2003, 2010 e 2012 Foto A: Luiz Abreu; Foto B e C: Felipe Costa.

Ressalta-se, mais uma vez, que São Luiz do Paraitinga ainda conserva suas características rurais e mantém uma relativa produção agropecuária, o que baliza uma forte presença de costumes e hábitos tradicionais, demonstrando uma tendência natural para o desenvolvimento do turismo nos espaços rurais. O poder público também tem desviado sua atenção para o turismo em áreas distantes do centro. O turismo rural no município hoje é visto como uma modalidade alternativa de atrações turísticas. Tal procedimento, além de deixar o 
nome da cidade ainda mais em evidência, traz divisas ao munícipio, coopera na geração de renda e de empregos nas comunidades afastadas do meio urbano. Isto posto, novos investimentos têm sido utilizados na promoção do turismo em áreas naturais, as quais englobam diversos atrativos como cachoeiras, passeio a cavalo, trilhas ecológicas, outros esportes de natureza ou simplesmente a tranquilidade do ambiente rural.

Apesar da realização de investimentos públicos com intuito de preservar e usufruir dos atrativos na fomentação do desenvolvimento do turismo, o município de São Luiz do Paraitinga, devido a falta de planejamento vem sendo muito afetado por intervenções pontuais e descoladas de realidade. Grandes eventos culturais, como o Carnaval e a Festa do Divino Espírito Santo, são divulgados pela mídia e pelo poder público local, porém, a falta de planejamento, compromete alguns equipamentos coletivos, o que resulta em problemas na preservação dos imóveis tombados e áreas naturais.

Assim como no período da economia do café, o turismo, hoje, é capaz de produzir bons resultados imediatos e impulsionar a economia local, mas é possível também, a longo prazo, acarretar uma grande descaracterização do patrimônio cultural. A degradação que o intenso movimento de turistas pode provocar em uma área de patrimônio será, provavelmente, vultuosa. Além do mais, é plausível causar desequilíbrios no setor terciário, no cotidiano da população, no caráter social do patrimônio, na cultura popular local e gerar mudanças na dinâmica da cidade, do meio rural e natural.

O patrimônio cultural é suscetível de ser o suporte para um futuro desenvolvimento de atividades turísticas voltadas para a história, arquitetura, tradições, sítios naturais, entre outros. A preservação e o usufruto dos patrimônios (sejam eles em áreas urbanas ou naturais) deve se integrar ao planejamento e se transformar em um vetor de desenvolvimento socioeconômico e sustentável para a população local.

\subsection{Potencialidades e atrativos turísticos}

Muitos municípios, atualmente, são estimulados ao desenvolvimento do turismo, fato em evidência de maneira especial depois das décadas de 1970 e 1980 . Nesse processo, as cidades estão redescobrindo suas potencialidades históricas, culturais e ambientais, que têm sido referenciadas como produtos a serem consumidos nessa nova realidade. É neste episódio que se insere o município de São Luiz do Paraitinga. 
O centro histórico de São Luiz do Paraitinga é objeto de estudo sistemático por parte do IPHAN, desde os anos de 1950. Porém, foi no ano de 1982, por meio de um Plano de Revitalização do Centro Histórico de São Luiz do Paraitinga, que o CONDEPHAAT tombou parte da cidade. Embora o Plano tenha dado ênfase à ocupação burguesa ao redor da praça central, no que diz respeito à arquitetura popular e à demarcação da área tombada, à semelhança das edificações e à densidade ocupacional, é preciso salientar a qualidade do levantamento e das ponderações que apoiaram tal Plano. As avaliações sobre a definição de Zonas de Ocupação para o Uso do Solo, as Zonas Envoltórias de Proteção Ambiental (conjunto urbano situado na parte externa da área tombada), e Zona Envoltória de Proteção Paisagística (as referências visuais no entorno do núcleo tombado, contemplando os aspectos naturais) também são dignas de serem ressaltadas (PAES, 2012).

Para se evitar a perda de um número ainda maior de bens culturais ocorridos pela inundação e para embasar juridicamente suas ações, o IPHAN, em 2010, logo após a enchente, tombou, em caráter emergencial, o conjunto urbano, cultural e natural de São Luiz do Paraitinga. Em dezembro do mesmo ano houve o seu tombamento definitivo, com a proteção de mais de 450 imóveis, numa área superior a 6,5 milhões de metros quadrados, no qual inclui o espaço urbano, rural e toda a paisagem natural contornada pelo "mar de morros ${ }^{34}$ que envolve o município (Jornal da Reconstrução, dezembro de 2010).

Além do patrimônio material, a cidade é reconhecida pelo seu patrimônio imaterial, rico e diversificado, marcado pela tipicidade de suas festas, pelas músicas tocadas e pelos artesanatos vendidos. Estas heranças culturais vêm desde o período colonial até os dias atuais, quando a memória e as expressões culturais locais ganham valor patrimonial e para a visitação turística ${ }^{35}$.

a) Conjunto arquitetônico

A cidade de São Luiz do Paraitinga é caracterizada por um centro histórico, oriundo da cultura cafeeira, com igrejas, casarões e ruas de pedras feitas pelos escravos.

\footnotetext{
${ }^{34}$ É uma denominação criada pelo geógrafo francês Pierre Deffontaines e consagrada pelo geógrafo brasileiro Aziz Ab'Saber, que se utilizou dessa expressão para designar o relevo das colinas dissecadas do Planalto Attântico (Serra Geral).

${ }^{35}$ A Lei Complementar n. 1044, de 13 de novembro de 2002, dispõe que o Conselho Municipal de Preservação do Patrimônio Histórico, Artístico, Urbanístico e Arqueológico pesquisará, identificará, protegerá e valorizará o patrimônio cultural do Município. A esse conselho é atribuída a tarefa de incentivar: "I - As atividades dos figureiros, do folclore e da música caipira; II - As festas populares; III - A preservação da memória de luizenses ilustres; IV - Manifestações artísticas no Mercado municipal; V - Festas do Divino Espírito Santo e de São Luiz de Toloza; VI - Carnaval”.
} 
São imóveis declarados de interesse paisagístico, histórico, arquitetônico e urbanístico, que situam a urbe em análise de modo relevante no patrimônio cultural do estado de São Paulo. A maior concentração de edifícios está na praça, na área urbana da cidade.

Concomitantemente à efetuação do tombamento, o CONDEPHAAT realizou um estudo sobre todos os edifícios e a cidade foi dividida seguindo suas características específicas em dois setores, que passaram a ser denominados Centro Histórico I e Centro Histórico II (figura 25).

O Centro Histórico I, com um alto grau de preservação, é formado por 171 edifícios tombados. Tal centro caracteriza-se pela presença de grandes sobrados, predominantemente do século XIX, quase todos construídos no alinhamento das ruas. O Centro Histórico II envolve 262 edificações, com construções de menor porte e alguns edifícios isolados. Esta área agrupa construções menos representativas do ponto de vista arquitetônico (PAES, 2012).

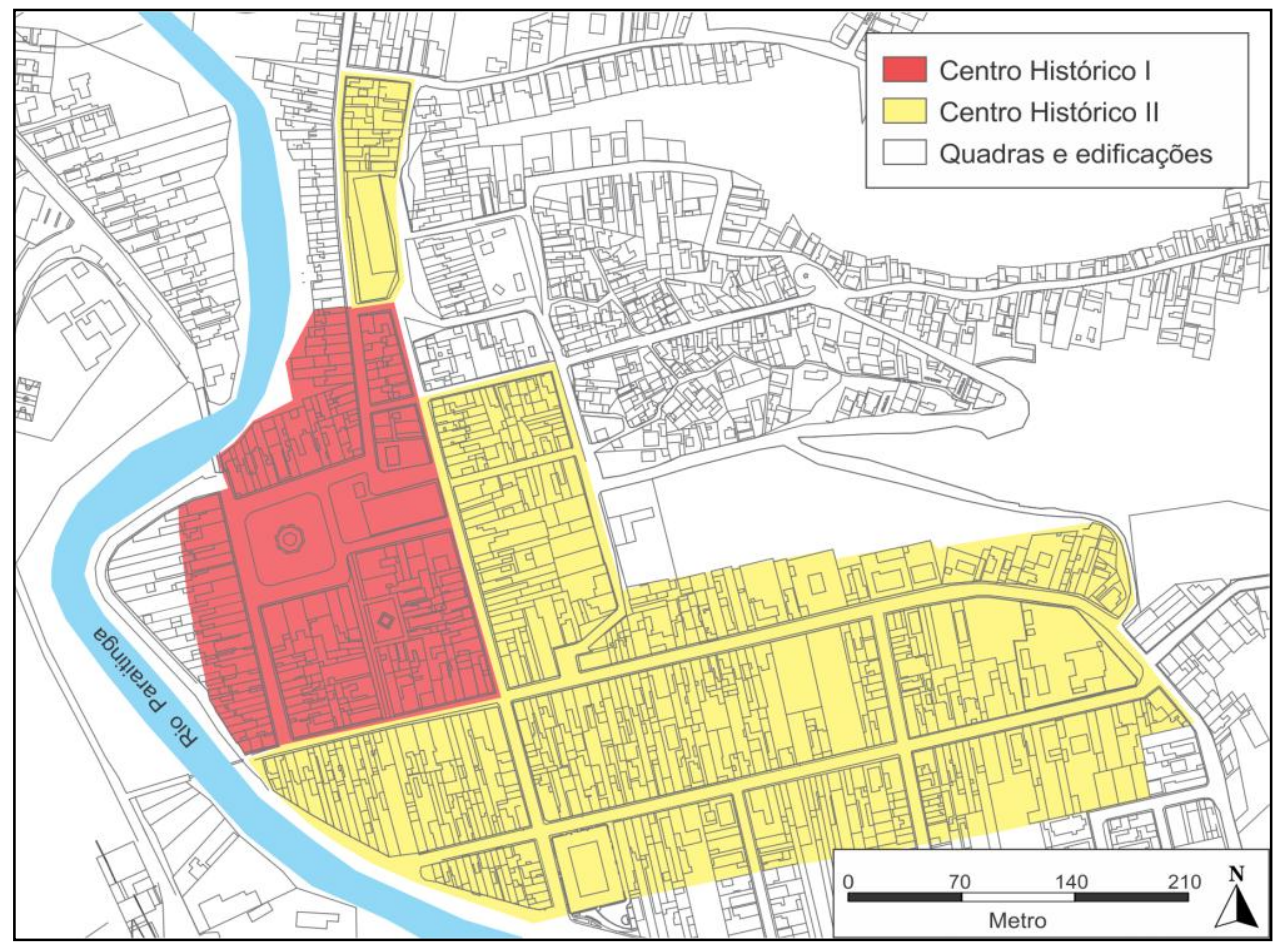

Figura 25 - Delimitação dos Centros Históricos I e II

Fonte: CONDEPHAAT, 1982. Adaptado de SANTOS, 2006.

Ainda segundo o CONDEPHAAT (1982), as edificações se diferem por graus de proteção (figura 26), os quais, resumidamente, são:

- Grau de Proteção 1 (GP1): Construções anteriores ao século XX e que possuem os espaços internos preservados. Prevê a conservação integral do imóvel (fachadas e divisões internas); 
- Grau de Proteção 1a (GP1a): Construções anteriores ao século XX, possuem os espaços internos preservados, mas passaram por pequena descaracterização, contudo passíveis de restauração. Devem ser conservadas integralmente;

- Grau de Proteção 2 (GP2): Construções anteriores ao século XX que sofreram descaracterização devido às intervenções impróprias impossíveis de serem restauradas. Prevê a conservação da estrutura e de elementos externos (fachadas e coberturas), permitindo as reformas internas;

- Grau de Proteção 3 (GP3): Edificações construídos no século XX. Devem ser preservadas no intuito de manter o visual do conjunto. Podem ser reformados e deve-se evitar a imitação do antigo e manter o equilíbrio urbano.

- Grau de Proteção 4 (GP4): Novas edificações. Cabe ao CONDEPHAAT orientar eventuais reformas e sempre evitar soluções que conduzissem a imitação do antigo, porém, respeitando a homogeneidade do núcleo urbano.

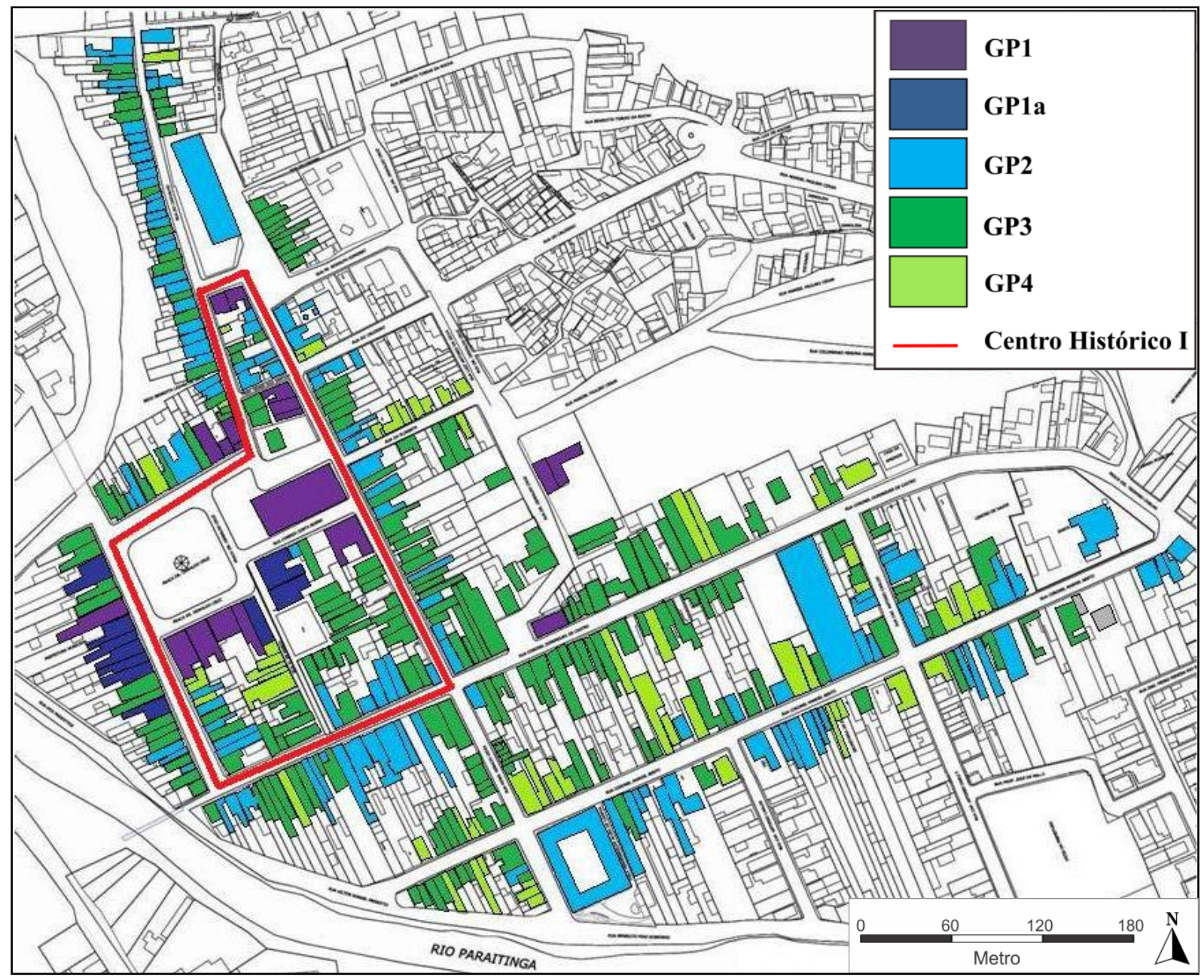

Figura 26 - Grau de proteção dos imóveis tombado Fonte: CONDEPHAAT, 1982. Adaptado de Pereira, 2012. 
Tal normatização, criteriosa e adequada às concepções de preservação do patrimônio cultural, direta ou indiretamente, alterou o modo de vida da cidade, de rural para urbano e dinamizou as atividades turísticas, criando, inclusive, um calendário para as festividades locais, populares e religiosas. Além disso, institucionalizou o valor do patrimônio cultural, quer seja para os visitantes, quer seja para os moradores que apenas viviam as suas histórias no seu lugar. Não poderiam supor que tais histórias por eles vividas e o lugar habitado seriam bens valiosos, fundados através de suas expressões materiais e imateriais gravadas na história e na produção do espaço (PAES, 2012).

Dentre os edifícios históricos e culturais ${ }^{36}$ (figura 27) destacam-se:

- Mercado Municipal: possui a forma de um quadrilátero todo em arcadas, tendo a parte central descoberta e contornado por um corredor. Em seu espaço há a venda de mercadorias como alimentos e artesanato local. É, também, um ponto de encontro dos habitantes em seus botequins e palco de algumas festividades e manifestações culturais.

- Casa Dr. Oswaldo Cruz: atualmente conhecido como Centro Cultural, a casa, uma antiga sede de fazenda, foi construída em 1834 em taipa de pilão, com as paredes internas de pau-apique. Local de nascimento do sanitarista brasileiro Osvaldo Cruz.

- Igreja do Rosário: edificada em estilo eclético, predominando o gótico decadente, constituise em elemento contrastante no conjunto urbano. É uma construção em taipa sobre alicerce de pedras da região.

- Igreja Matriz: dedicada a São Luiz de Toloza. A primeira edificação da igreja foi do século XIX (1839). Os recursos vieram da colaboração de famílias abastadas da época que recebiam a garantia de serem enterradas lá. Depois da destruição total na enchente de 2010, foram encontrados muitos destes túmulos.

- Capela Nossa Senhora das Mercês: uma das primeiras construções da cidade, erguida no século XVIII. Suas paredes são de taipa de pilão e é a única em estilo colonial da cidade.

- Casarão do Barão do Paraitinga: pertenceu ao Barão do Paraitinga e até hoje mantém os mesmos usos do período que foi construída, comércio na parte inferior e residência na parte superior. Os habitantes mais antigos dizem que foi o primeiro casarão construído na cidade, em 1853.

\footnotetext{
${ }^{36}$ Após a enchente esses edifícios sofreram alterações em suas estruturas arquitetônicas. A CONDEPHAAT e IPHAN, órgãos estadual e federal de proteção ao patrimônio, executaram diversos estudos práticos e elaboraram novos projetos a fim de recuperar os edifícios e mantendo-os o mais próximo possível de suas construções originais. Isso foi possível após uma consulta à comunidade. Além disso, todas as edificações possuem ricos estudos de tombamento, com plantas detalhadas de estrutura e material cartográfico e fotográfico, processos, relatórios e documentos elaborados na década de 1970. Tais fatores facilitaram o trabalho de reconstrução do patrimônio.
} 


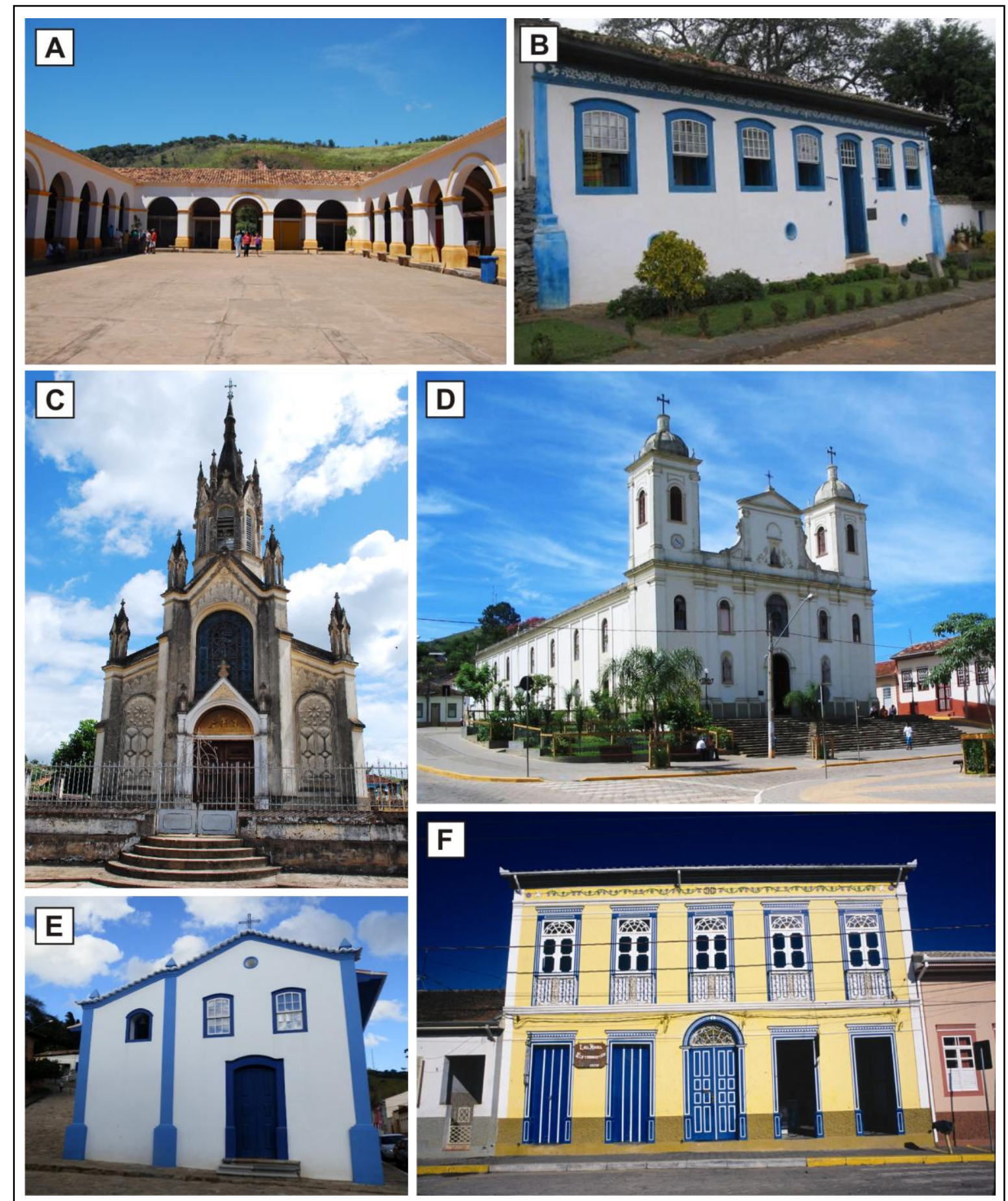

(A) Mercado Municipal; (B) Casa Dr. Oswaldo Cruz; (C) Igreja do Rosário; (D) Igreja Matriz; (E) Capela Nossa Senhora das Mercês; (F) Casarão do Barão do Paraitinga

Figura 27 - Principais edifícios históricos e culturais

Fotos A, B, C e E: arquivos pessoais, 2012, 2009, 2012 e 2009; Foto D: Danilo Sanches, 2009; Foto F: Sérgio Costa, 2013.

Além disso, na área rural existem fazendas antigas que foram construídas no século XIX, a partir da década de 30 (figura 28). Essas construções apresentam uma arquitetura colonial, cuja representatividade é do período áureo do café, com a presença de senzalas e 
casas de máquinas. Tais fazendas, hoje, adquirem uma nova função (algumas se tornaram meios de hospedagens) e valorizam a presença do turismo rural do município.

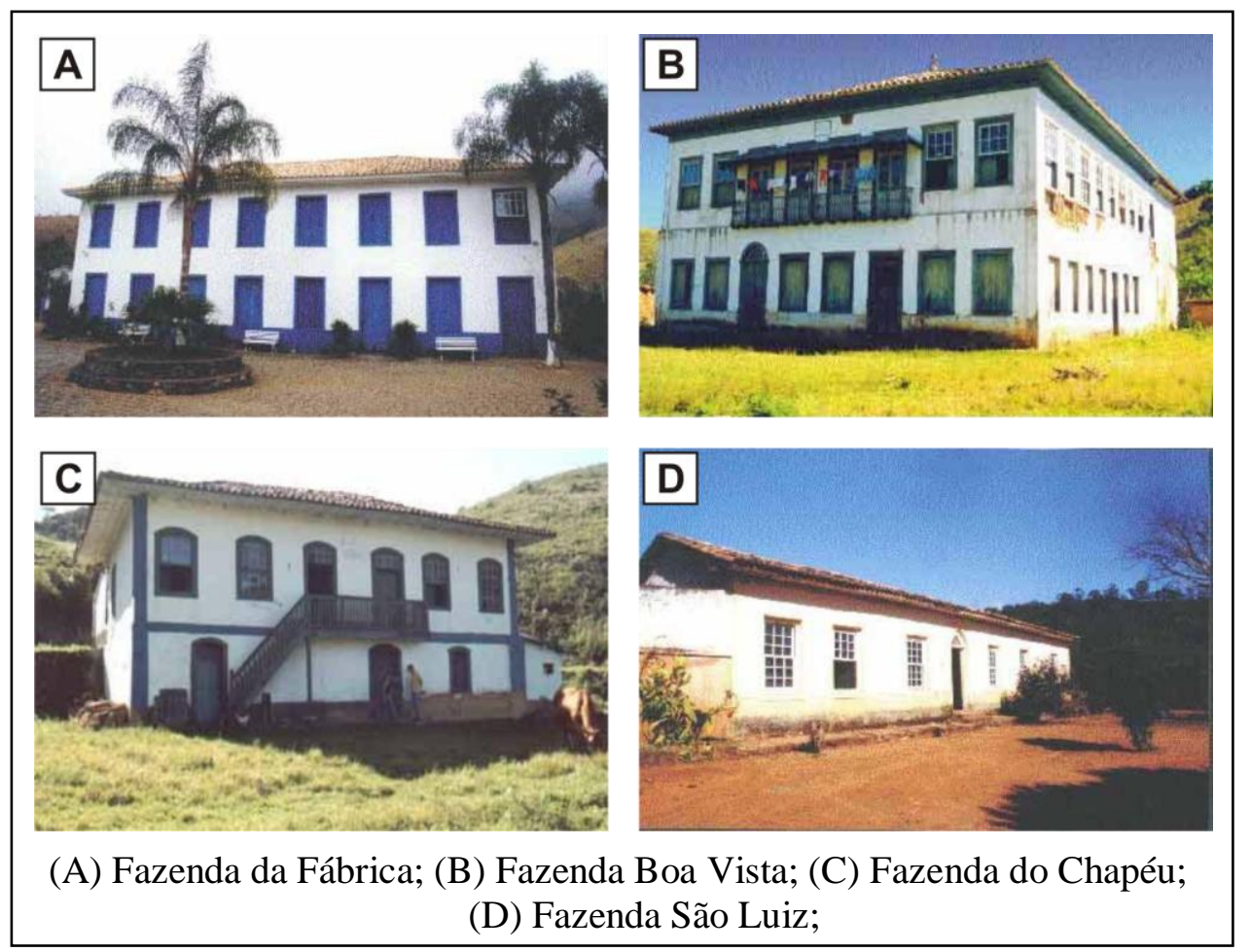

Figura 28 - Principais sedes de fazendas históricas Fotos: Marcelo Toledo, 2006.

a) Festas

Sejam por motivos religiosos ou não, a cidade tem tradição de organizar festas populares que apresentam muito da cultura regional. A Praça Dr. Oswaldo Cruz é o ponto central de todos os eventos festivos. Faz-se aqui um breve relato de algumas datas festejadas (figura 29) e as suas principais características:

- Carnaval: é um dos mais originais do Estado de São Paulo, amplamente divulgado pelos meios de comunicação. É baseado na cultura do povo da cidade, com seus mitos, lendas e tradições. Tudo regado a marchinhas carnavalescas de origem local. Blocos e cordões apresentam-se nas ruas, tendo como cenários a praça e os casarões coloniais.

- Festa do Divino Espírito Santo: ocorre no mês de maio, com uma novena, realizada na igreja Matriz. Ali são bentas as bandeiras dos fiéis, que desfilarão pelas ruas nas cerca de 20 procissões realizadas nos 10 dias da festa. As procissões são acompanhadas pela banda de música, pela Folia do Divino e por dezenas de pessoas que levam bandeiras em sinal de devoção e pagamento de promessas por graças alcançadas. 
- Festa do Saci: a Sosaci (Sociedade dos Observadores de Saci) é uma das promotoras da festa que conta com as marchinhas do Bloco do Saci, puxado pelos bonecos criados por um artesão popular, o Zé Paulino e Angu, um casal gigante com cara de pererê.

- Semana da Canção Brasileira: projeto organizado pela Secretaria de Estado da Cultura dentro de uma iniciativa de valorização e promoção de eventos, de acordo com a vocação cultural identificada em cidades do interior paulista.

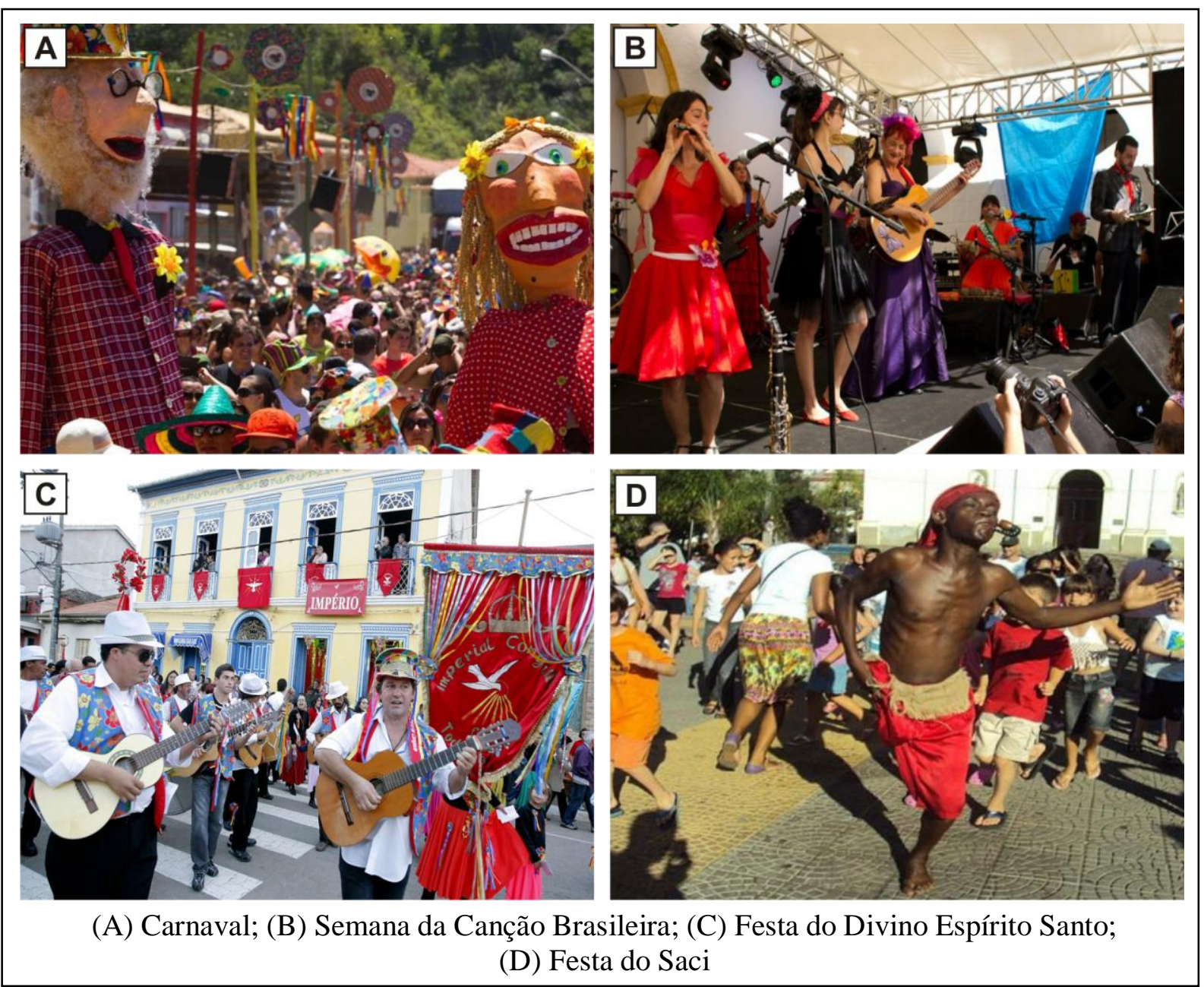

Figura 29 - Principais festas populares e tradicionais

Fotos A: Cássio Roosevelt, 2012; Foto B: Paulinho de Jesus, 2011; Foto C: José Patrício, 2011; Foto D: Prefeitura de São Luiz do Paraitinga, 2011.

a) Música

Nas primeiras décadas do século vinte, São Luiz do Paraitinga distinguia-se entre outras cidades por possuir três bandas musicais: a Santa Cecília, a do Santíssimo Sacramento e a São Benedito. Na música do povo, principalmente da área rural, existiam nessa mesma época 18 grupos de Moçambique, sendo classificado pelo estudioso, pesquisador e folclorista Alceu Maynard Araújo, como a Capital da Zona Moçambiqueira Paulista, além dos 
cantadores das Folias de Reis e do Divino. Havia, também, o "Jazz Marabá" que tocava em associações recreativas, nos cinemas da região e até de São Paulo. Na década de 80, surgiu o Grupo Regional "Paranga", que alcançou grande receptividade na mídia nacional com um trabalho voltado para a pesquisa da cultura popular local e sobre as obras do músico e compositor Elpídio dos Santos, pai de quatro componentes do grupo e autor das trilhas sonoras dos filmes do Mazzaroppi. Atualmente, há vários grupos musicais da cidade em atividade.

b) Artesanato

Diversas atividades, como a cerâmica, potes, moringas para armazenar água, cuscuzeiros, vasos, tapetes, redes, bordados, juntamente com imagens de santos, animais e figuras típicas do cotidiano luizense são apresentados. Além disso, há os trabalhos em madeira e em taboa, que são produzidos pelas mãos hábeis e talentosas dos artesãos. Entre eles destacam-se gamelas, pilões, monjolos e pequenos engenhos para moer cana, entre outros instrumentos de utilidade doméstica.

c) Áreas naturais

O município de São Luiz do Paraitinga, originalmente coberto pela Floresta Atlântica estabelecida sobre os mares de morros do Planalto Atlântico, tem testemunhado o uso intensivo das áreas naturais, resultando em predomínios de pequenos fragmentos de florestas secundárias.

$\mathrm{O}$ incremento de atividades agropastoris e plantio de eucalipto nas áreas de mata, cuja vegetação original predominante era a Floresta Ombrófila Densa, ocasionou alterações paisagísticas e impactos ambientais negativos. Tal fato pode ser identificado por meio de alguns ciclos econômicos principais como a policultura, presentes em todos os ciclos. Para isso, as matas eram derrubadas e queimadas. Ao final do período do café, já era notável a escassez de florestas no município e com o abandono dos cafezais, as capoeiras disseminaram-se pela paisagem do munícipio. Nas últimas décadas, a pecuária, a agricultura de pequena escala e, recentemente, a monocultura do eucalipto, também impedem, em menor ou maior ou menor extensão, a regeneração florestal (MELLO, 2009).

Apesar disso, São Luiz do Paraitinga ainda possui 15.946 hectares (21,6\% da área total do município) recobertos pela Mata Atlântica. Dessa cobertura florestal, 7.700 hectares $(10,5 \%)$, encontram-se no interior do Parque Estadual da Serra do Mar (declarado pela Unesco como Patrimônio da Humanidade em 1991), sob proteção legal. Somando a área do Parque à área encontrada na zona de amortecimento (ao redor do local), 22.100 hectares (30\%) do município possuem cobertura florestal (MELLO, 2009). 
O Parque Estadual da Serra do Mar foi criado por meio do Decreto $\mathrm{n}^{\circ} 10.251$, em 1977. Originalmente, sua área era composta da junção de diversas reservas e outras unidades de conservação já existentes. As unidades de conservação estabelecem uma gestão participativa, integrada e sustentável dos recursos naturais, com o objetivo de preservar a diversidade biológica, melhorar a qualidade de vida das populações, fomentar as atividades de pesquisa e a educação ambiental, assim como a recreação em contato com a natureza e o turismo ecológico. Estas áreas foram instituídas para resguardar o patrimônio cultural e natural dos biomas ameaçados, neste caso, a Mata Atlântica (SMA, 2006) ${ }^{37}$.

Por se tratar de uma área de enorme extensão, o Parque Estadual da Serra do Mar é gerenciado por meio de oito núcleos administrativos e regionais. Isso acontece com a finalidade de facilitar sua gestão. Tais núcleos configuram um mosaico de situações diversas, caracterizadas em função do uso do solo e dos programas de manejo desenvolvidos ou potenciais, demandando uma atuação diferenciada da administração, considerando, ainda, o domínio das terras, que são públicas ou estão em diversos estágios de regularização fundiária.

O Núcleo Santa Virgínia é um dos núcleos de desenvolvimento do Parque Estadual da Serra do Mar. Engloba em sua área porções dos municípios de São Luiz do Paraitinga, Natividade da Serra, Cunha e Ubatuba. As nascentes provenientes das cachoeiras do núcleo são as principais formadoras do rio Paraíba do Sul e abastecem nove milhões de pessoas que vivem no Vale do Paraíba Paulista e Fluminense. As estradas e trilhas encontradas no interior do local foram construídas pelos escravos e demonstram, mais uma vez, a importância da travessia da Serra do Mar pelos tropeiros. Esse núcleo, por não ser totalmente desapropriado, também é composto por fazendas e sítios com atividades voltadas à pecuária, silvicultura, à subsistência e ao lazer (SMA, 2006). As atividades de lazer abarcam os esportes de natureza, principalmente o rafting (descida em botes por corredeiras de rios), rapel (escaladas de picos e montanhas), cascading (descida de uma cachoeira através de corda, utilizando a técnica do rapel), tracking (caminhada por trilhas), entre outras. A região possui um relevo bastante acidentado, repleto de quedas d'água e riachos cristalinos, fatores que atraem tais atividades turísticas. O Núcleo Santa Virgínia recebe aproximadamente cinco mil visitantes por ano.

\footnotetext{
${ }^{37}$ Mais informação sobre unidades de conservação consulte: SISTEMA NACIONAL DE CONSERVAÇÃO DA NATUREZA (SNUC). Decreto n ${ }^{\circ} 4.340$, de 22 de agosto de 2002.
} 


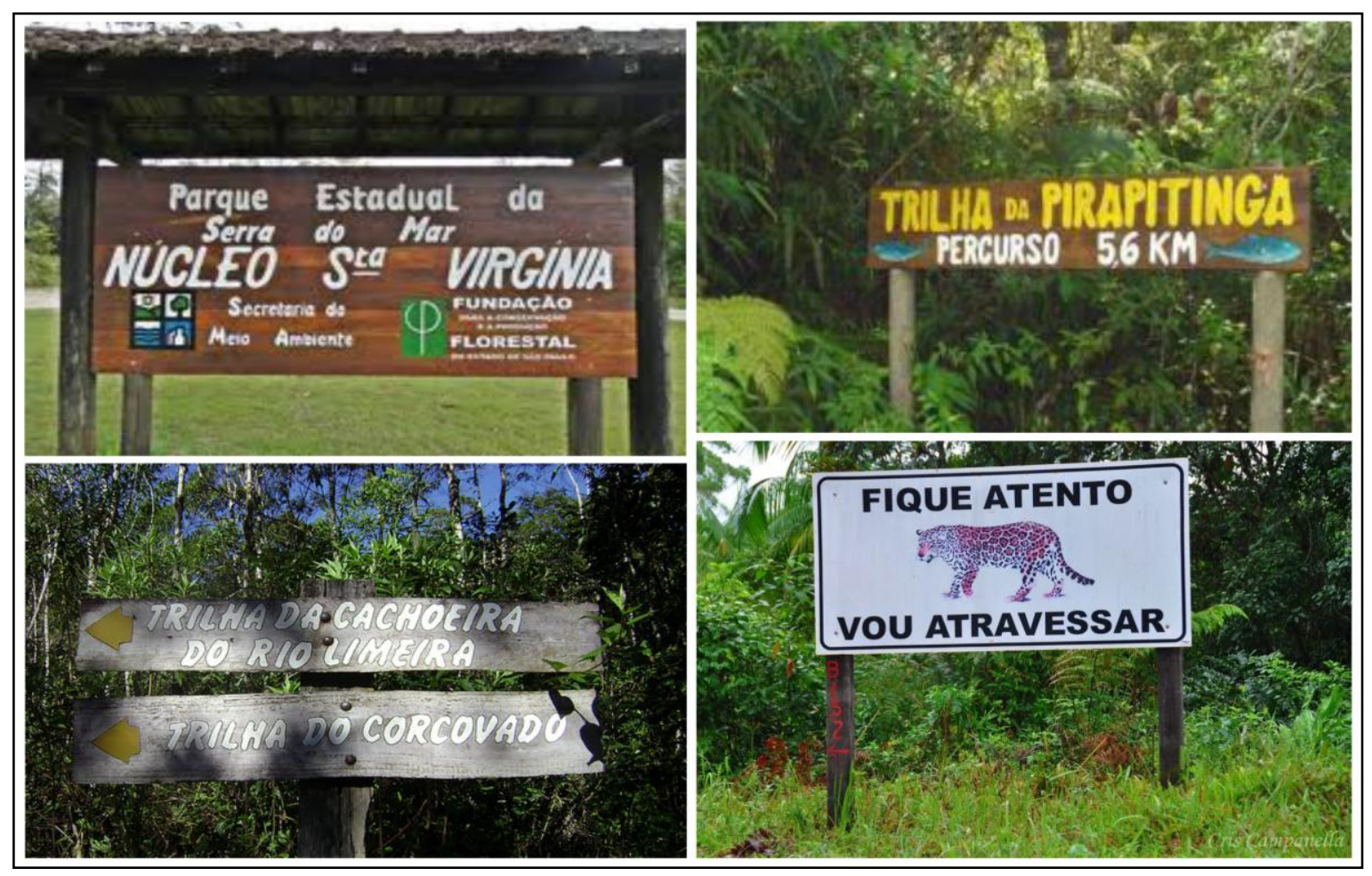

Figura 30 - Sinalizações Turísticas no Núcleo Santa Virgínia

Fotos: Alfredo Xavier, 2012; Cris Campanella, 2011

O fato de São Luiz do Paraitinga estar sob proteção legal exige alguns critérios diante das intervenções produzidas em seu espaço, na medida em que existem limites restritivos acentuados em relação ao uso e ocupação do solo. Tais restrições impostas pelas leis, paradoxalmente propicia o turismo voltado à natureza, que se apropria das paisagens preservadas ou poucos alteradas, impulsionando as atividades turísticas no munícipio.

Acredita-se que uma atividade turística voltada à natureza em áreas protegidas pode proporcionar benefícios econômicos. Porém, a preservação da mesma é de extrema importância. Os usuários devem ser orientados e os critérios de preservação bastante definidos. No entanto, é sabido que toda e qualquer atividade introduzida em áreas preservadas, necessariamente irá impingir impactos, sejam eles de maior ou menor intensidade, positivos ou negativos.

\subsection{O Turismo e a refuncionalização do espaço}

Como apontados nos subcapítulos anteriores, o fenômeno turístico de São Luiz do Paraitinga tem sua origem ligada a atrativos patrimoniais culturais, festas religiosas e arquiteturas históricas, além de rios, cachoeiras, mata e a tranquilidade rural. Ao lado deste sucesso e desenvolvimento do turismo, começam a surgir transformações socioespacial. 
O êxodo rural motivado pelas alterações no campo está provocando algumas modificações na cultura local. Por se tratar de uma cultura caipira, nota-se a transformação no tempo e no espaço. A questão é conciliável com a nova dinâmica inserida no município com a afirmação do turismo, bastante dependente do patrimônio cultural.

Se confrontada com outras cidades de médio e grande porte, as promoções imobiliárias atuante no município são pequenas, mas não se deve menosprezá-las.

Em meados da década de 1990, foi construído um loteamento na urbe. Segundo Santos (2006), tal procedimento prejudicou de maneira violenta o entorno do centro histórico local, alterou a paisagem e avultou o assoreamento do rio Paraitinga. Em 2003, ao construir um conjunto habitacional para famílias carentes, o Estado também atuou como um agente imobiliário. O conjunto foi edificado às margens do rio, área totalmente imprópria para tal procedimento. Ainda conforme o autor supracitado:

Com poucas áreas propícias à expansão urbana, as encostas e fundos de vale, estão sendo ocupadas de forma descontrolada por construções variadas, que vão desde uma escola pública, a loteamentos residenciais e ruas. [...] Nota-se um crescimento considerável da área urbana construída, ocupando quase por completo a vertente do Morro do Cruzeiro voltada para o Centro Histórico uma ocupação realizada por famílias de baixa renda, já que o local não é propício à construção de residências (SANTOS, 2006, p. 28-29).

Os agentes responsáveis pela (re)produção do espaço criam e recriam formas espaciais. Estas, diante da ação social, vão, frequentemente, amanhando novas funções. Uma área abastecida de bens patrimoniais é um espaço que deve estar apto a ingerências ajustadas a uma nova dinâmica designada ao turismo.

A sociedade passa por períodos de rápidas modificações e a valorização do entretenimento resplandece de forma mais intensa neste século. O turismo no município de São Luiz do Paraitinga, como vetor de expansão econômica, é apregoado e incorporado pelas políticas públicas e táticas econômicas. Em um momento cuja produção de imagens assume uma posição estratégica no planejamento do lugar, a espetacularização do patrimônio cultural passou a ser um instrumento primordial na refuncionalização do território com vistas ao desenvolvimento do lugar por meio do incremento do turismo (SANTOS, 2006).

Acredita-se que tal fato pode ter sido impulsionado a partir de propostas sugeridas no Plano de Revitalização do Centro Histórico. Neste, há uma pauta que evidencia recomendações voltadas para a melhoria da infraestrutura com o intuito de acentuar a valorização turística do município, tanto por suas características arquitetônicas, como também dos bens imateriais e dos patrimônios naturais: 
Visando criar condições que possam reanimar esse acervo cultural, marginalizado do processo de desenvolvimento global, o Plano de Revitalização, ora elaborado para a cidade, pretende diversificar a oferta de equipamentos hoteleiros com capacidade de impulsionar um turismo de massa, deflagrando, como consequência, substanciais benefícios para a região (CONDEPHAAT, 1982, p. 143).

Neste período, apesar da cidade, para acolher as necessidades cada vez mais crescentes com relação ao turismo, ter alavancado sua economia com o setor de serviços, não se consultou a população, portanto, os moradores não participaram de tais ingerências. Ficaram alienados quanto aos projetos e as modificações de usos. A praça central, por exemplo, foi transformada em palco para os festejos do carnaval. "O centro histórico de São Luiz do Paraitinga já havia sido consagrado como palco de visitação turística” (PAES, 2012, p.26).

Outra recomendação do CONDEPHAAT excedida foi a ampliação urbana e o aumento das reformas não adequadas à preservação do patrimônio arquitetônico. Este trabalho foi, muitas vezes, realizado com o objetivo de servir de cartão postal para se atrair turista, como, por exemplo, a utilização de cores fortes e variadas nas fachadas das edificações. Deve-se ressaltar, ainda, os patrimônios rurais e naturais. Alguns casarões antigos nas zonas rurais tornaram-se meios de hospedagens e algumas pousadas e trilhas foram colocadas, instaladas próximas a atrativos turísticos como cachoeiras e mirantes.

Assim, com os olhos voltados ao futuro, um passado que se pretende conservar o e os acontecimentos dinâmicos do presente repletos de contradições que acabam em resultados não propositais, chega-se a um 'divisor de águas' importantíssimo entre a preservação do patrimônio cultural original e a refuncionalização do espaço turístico. Nesta conjuntura, o episódio da enchente em 2010 tem um aspecto relevante na redefinição valorativa do patrimônio cultural (PAES, 2012).

Vários planos técnicos foram apresentados para se recuperar os centros históricos quando afetados por acidentes ambientais. Diante de um cenário de destruição, a habilidade de criação e de reprodução de paisagens construídas foi enorme, e este é um apanágio, um atributo que deve ser levado na devida consideração.

De acordo com PAES (2012, p.32) "é no presente que se deve construir a realidade, com os eventos, as ações, as formas e as intencionalidades que ela nos apresenta". Nesta acepção entre preservar a memória com a finalidade de assegurar a identidade cultural num campo de conflito de interesses, e o futuro que se imagina ao normatizar tecnicamente as áreas culturais, São Luiz de Paraitinga serve como um modelo para se pensar sobre o patrimônio cultural e seus valores turísticos atrelados ao desenvolvimento do munícipio. 


\section{Capítulo 5}

\section{CARTOGRAFIA DE ANÁLISE E CARTOGRAFIA DE SÍNTESE: TIPOS DE PAISAGEM E PROPOSTA DE ZONEAMENTO TURÍSTICO PARA O MUNICÍPIO DE SÃO LUIZ DO PARAITINGA}

Apresenta-se, neste capítulo, uma coleção de mapas temáticos que possibilitará a aplicação de sucessivos raciocínios, embasados nas premissas teórico-metodológicas, explanadas no presente estudo. O agrupamento destes tais mapas analíticos fornecerá a base necessária para a elaboração do mapa síntese, delimitado e identificado por tipos de paisagem e, a partir deste, conceber-se-á uma proposta preliminar do zoneamento turístico para o município de São Luiz do Paraitinga.

\subsection{Cartografia de análise}

Por meio dos dados, informações e ensaios desenvolvidos nos capítulos anteriores, torna-se possível a confecção de mapas temáticos, com a finalidade de ampliar o entendimento de alguns fenômenos geográficos do município de São Luiz do Paraitinga e compreender como os mesmos são valiosos para o desenvolvimento do turismo.

Com o intuito de atingir uma visão compatível à proposta preliminar de zoneamento turístico nesta etapa do trabalho, um conjunto de materiais foi utilizado para a coleta e tratamento de dados espaciais. Concomitante a esse processo, o levantamento de bases cartográficas é de extrema importância, pois subsidiam a interface entre a cartografia e o geoprocessamento, e possibilitam a confecção de mapas temáticos. Na elaboração e interpretação dos mapas, as bases cartográficas foram manipuladas em ambiente SIG, mais precisamente, o software ArcGis10. ${ }^{38}$

Os mapas temáticos analíticos foram gerados por meio dos dados alfanuméricos e geográficos. Estes mapas mantêm relações mútuas e dependentes, resultando em algo expressivo, cujas partes nem sempre são visíveis, mas passíveis de entendimento. O mapa analítico mostra a distribuição de um ou mais elementos de um fenômeno, utilizando dados primários, com as representações necessárias para a sua visualização.

\footnotetext{
${ }^{38} \mathrm{O}$ ArcGis é um software privado e de propriedade da Empresa Environmental Systems Research Institute (ESRI). É um software utilizado em análises de sistemas de informações geográficas (SIG).
} 
Nesta pesquisa, aplicou-se, em especial, uma seleção de dados planimétricos e os dados altimétricos contidos nas cartas topográficas de São Luiz do Paraitinga, Lagoinha, Natividade de Serra e Ubatuba $^{39}$ na escala 1:50.000 e disponibilizadas pelo IBGE.

Especificamente, os dados altimétricos foram extraídos para elaborar o mapa de relevo. Acredita-se que o relevo é uma das bases para a sustentação da evolução das paisagens, bem como uma das primeiras variáveis a ser considerada em sua análise.

Em um plano horizontal, a representação do relevo da carta topográfica é feita através das curvas de nível, pontos cotados e produzida em cores (JOLY, 1990). Na escala do material utilizado nesta temática, as curvas possuem uma equidistância de 20 metros. Porém, devido ao tamanho reduzido do mapa elaborado para este estudo e as caracteristicas peculiares de algumas áreas serranas do município, optou-se por representar as curvas com equidistância de 100 metros, o que possibilita uma leitura menos congestionada.

O mapa do relevo em curvas de nível, convenientemente acrescenta matizes de cores em ordem visual crescente, das mais claras às mais escuras, entre as cores quentes, acompanhando a progressão para o alto das cotas de altitude, isto é, cores claras, nas baixas altitudes, passando, depois, para os ocres e destes para os marrons, nas áreas montanhosas. Este mapa caracteriza-se por suas relações quantitativas junto às isolinhas de altitude, porém, em termos de visualização, obter-se-á apenas a expressão da informação de nível ordenado, não possibilitando a avaliação quantitativa. A noção do quanto de altitude é obtida pela leitura da legenda. (BERTIN, 1973; 1977). Além disso, em uma outra forma de se representar o relevo (mapa clinográfico), o espaçamento entre as linhas do mapa topográfico também pode ser traduzida pela representação, por uma seleção criteriosa de facetas organizadas em valor visual crescente, transcrevendo a visualização de declividade.

A ordem visual promovida pela representação em isolinhas coloridas permitiu uma nítida precepção na sequência crescente das altitudes marcadas pelo relevo do município. Observa-se, na porção central e norte, o relevo com altitudes mais baixas (800 e 900 metros), região que predomina a área urbana e as margens do rio Paraitinga, o qual aumenta no sentido sul, atingindo a cota máxima de 1.600 metros e, outra vez, volta a diminuir na direção ao leste.

\footnotetext{
${ }^{39}$ São Luiz do Paraitinga - folha SF-23-Y-D-III-1. Ano: 1974; Lagoinha - folha SF-23-Y-D-III-2. Ano: 1973; Natividade da Serra - folha SF-23-Y-D-III-3. Ano: 1974; Ubatuba - folha SF-23-Y-D-III-4. Ano: 1981.
} 


\section{SÃO LUIZ DO PARAITINGA (SP): RELEVO}

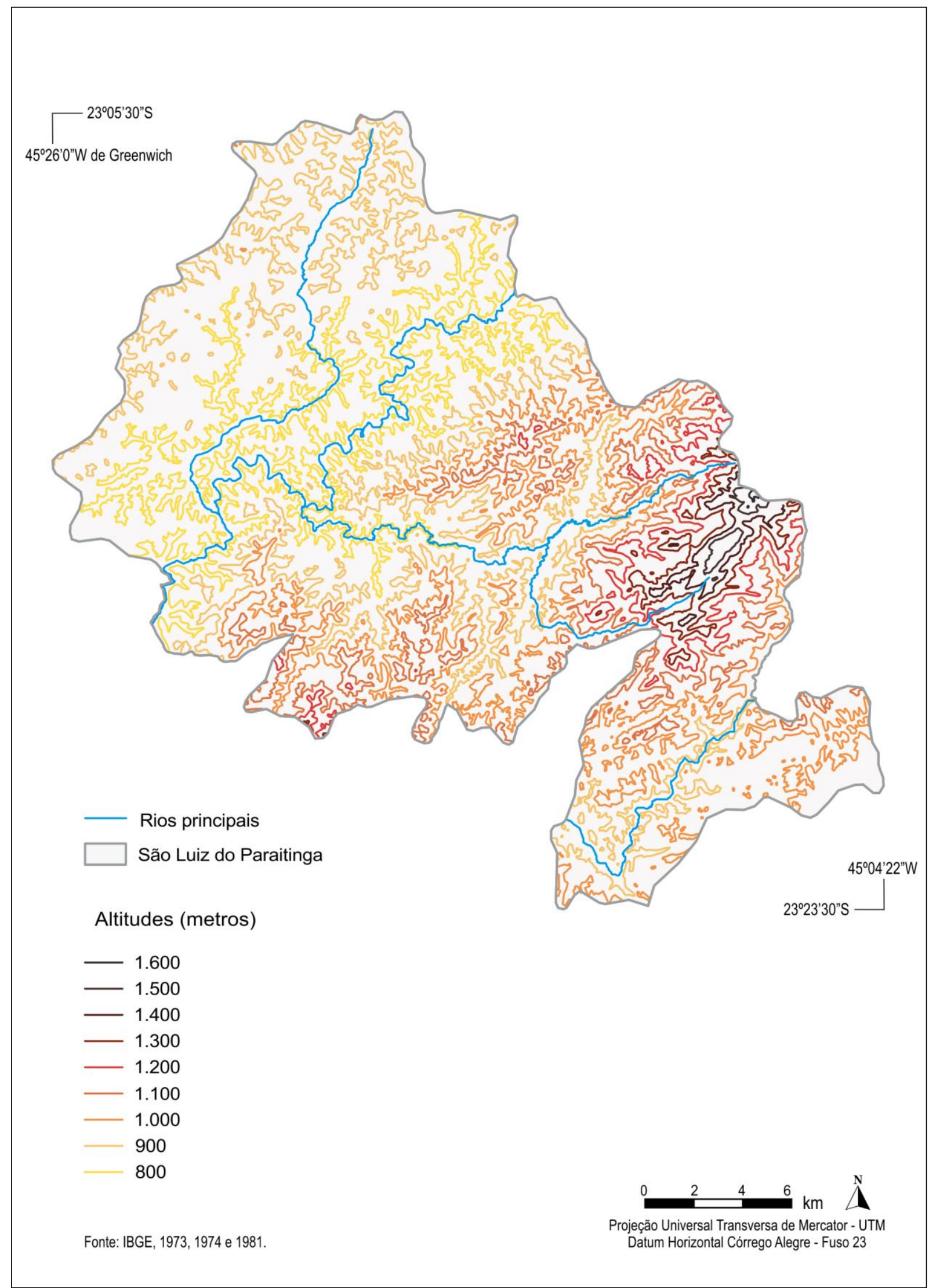

Figura 31 - Mapa do relevo de São Luiz do Paraitinga (SP) representado com isolinhas coloridas em ordem crescente. 
O relevo, quando vinculado ao turismo, é proferido por Conti $(2003$, p.61) na seguinte definição:

O relevo é uma característica geográfica muito significativa e um dos componentes de identidade regional, podendo associar-se à atividade turística de diversas maneiras. A beleza cênica, a suntuosidade de uma configuração e até mesmo seu componente simbólico constituem atrativos nada desprezíveis que podem se transformar em mercadorias a serem vendidas.

Diante do mapa exposto, faz-se necessário destacar a importância da visualização do relevo por um efeito plástico oferecido pelo sombreado. Este é executado diretamente em função das curvas de nível e constituído por meio de cálculos matemáticos que, hoje, recebem o auxílio do uso de novas geotecnologias.

Acredita-se que apresentações dessa natureza facilitam o entendimento das relações geográficas, proporcionando a compreensão de elementos e fenômenos espaciais por especialistas, e até mesmo por indivíduos da sociedade que não possuem conhecimentos técnicos e específicos.

Mapas de relevo sombreados ajudam o usuário a visualizar dados de superfície tridimensionais em um ambiente bidimensional de maneira mais realista. As feições são iluminadas de acordo com a posição de uma fonte de luz imaginária, situada no alto e a noroeste, deixando sombras que tornam tais feições reconhecíveis.

Elaborou-se o mapa a seguir (figura 32) a partir da adição dos dados no 3D Analyst (extensão do software ArcGis). Foram utilizadas as mesmas bases cartográficas do mapa anterior, porém, optou-se em permanecer as curvas de nível com equidistâncias de 20 metros e os pontos cotados do mapa que serviu de fonte.

Com o uso do software, torna-se possível classificar os intervalos de altimetria, de acordo com os anseios do usuário. Deste modo, utilizou-se uma classificação por intervalos de 100 e 200 metros com a finalidade de facilitar a leitura apresentada na vigente escala do mapa impresso. Aplicaram-se diversos matizes em ordem visual crescente. Neste mapa, as cores verdes representam as altitudes mais baixas e as tonalidades marrons vão escurecendo conforme as altitudes se tornam mais elevadas, porém, optou-se em clarear os topos com o propósito de destacar e facilitar a leitura do relevo na escala vigente. Os tons intermediários são executados quando se passa, lentamente, da parte iluminada para a sombra. 
SÃO LUIZ DO PARAITINGA (SP): RELEVO SOMBREADO

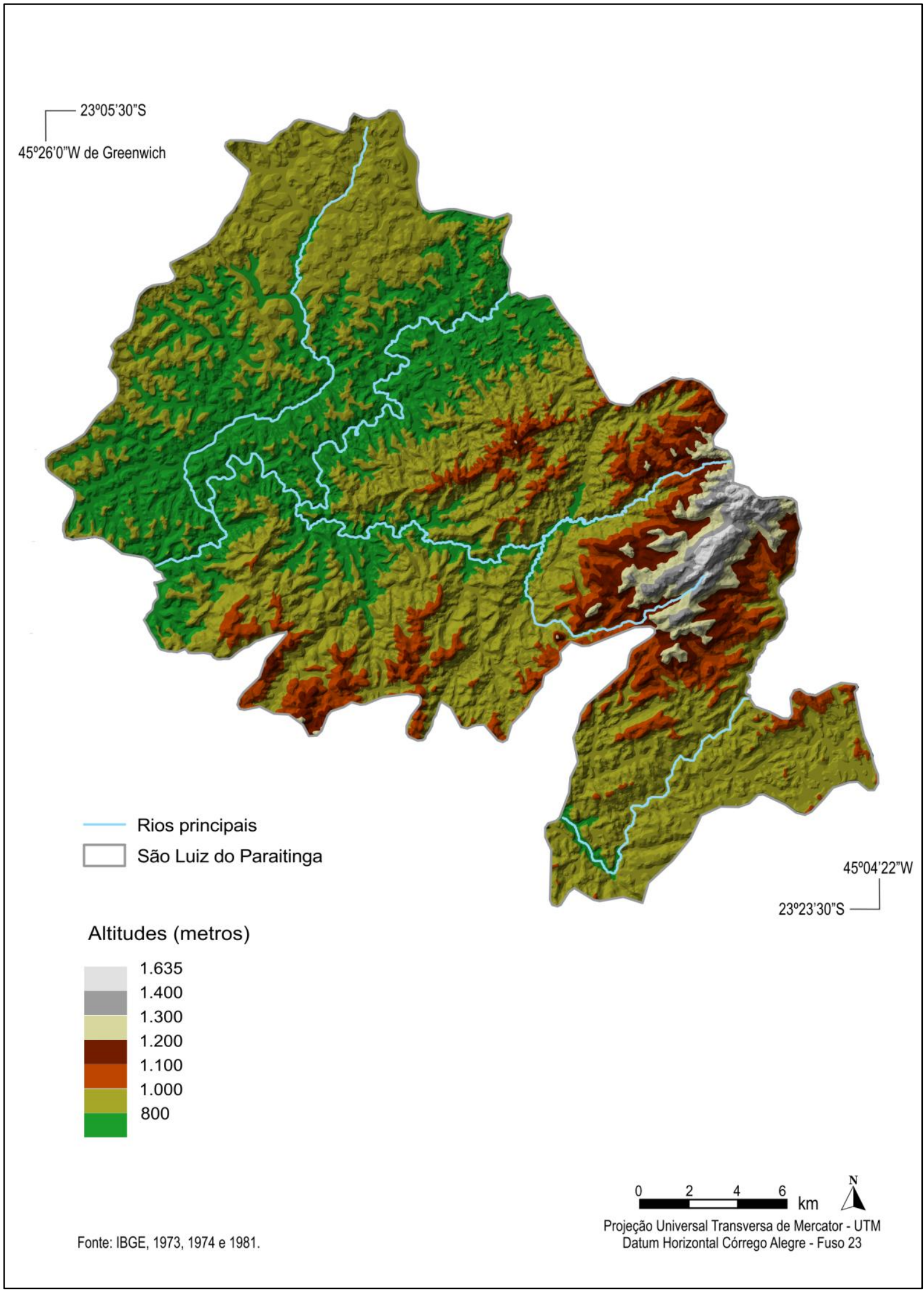

Figura 32 - Mapa do relevo de São Luiz do Paraitinga (SP) representado por cores hipsométricas com sombreado. 
Assevera-se, mais uma vez, que a geomorfologia do município é marcada pelo domínio de "mares de morros". Estes estão modelados em rochas graníticas e metamórficas do período pré-cambriano, assentadas no complexo cristalino, formando uma paisagem de colinas e declividades predominante entre 20 e $30 \%$, e apresentam formas mamelonadas ${ }^{40}$, às vezes muito dissecadas e vales entalhados, associados à alta densidade de drenagem. Tais fatores resultam em um grau de fragilidade potencial alto, sendo, portanto, uma área sujeita a processos erosivos agressivos, com probabilidade de ocorrência de movimentos de massa e erosão linear com voçorocas (MELLO, 2009).

Dessa forma, a população luizense pode ficar exposta ao risco, pois o relevo de "mares de morros" (figura 33), em muitas áreas mais baixas e planas junto aos rios, apresenta terraços fluviais passíveis de inundações, causadas pelas cheias em época de chuvas.

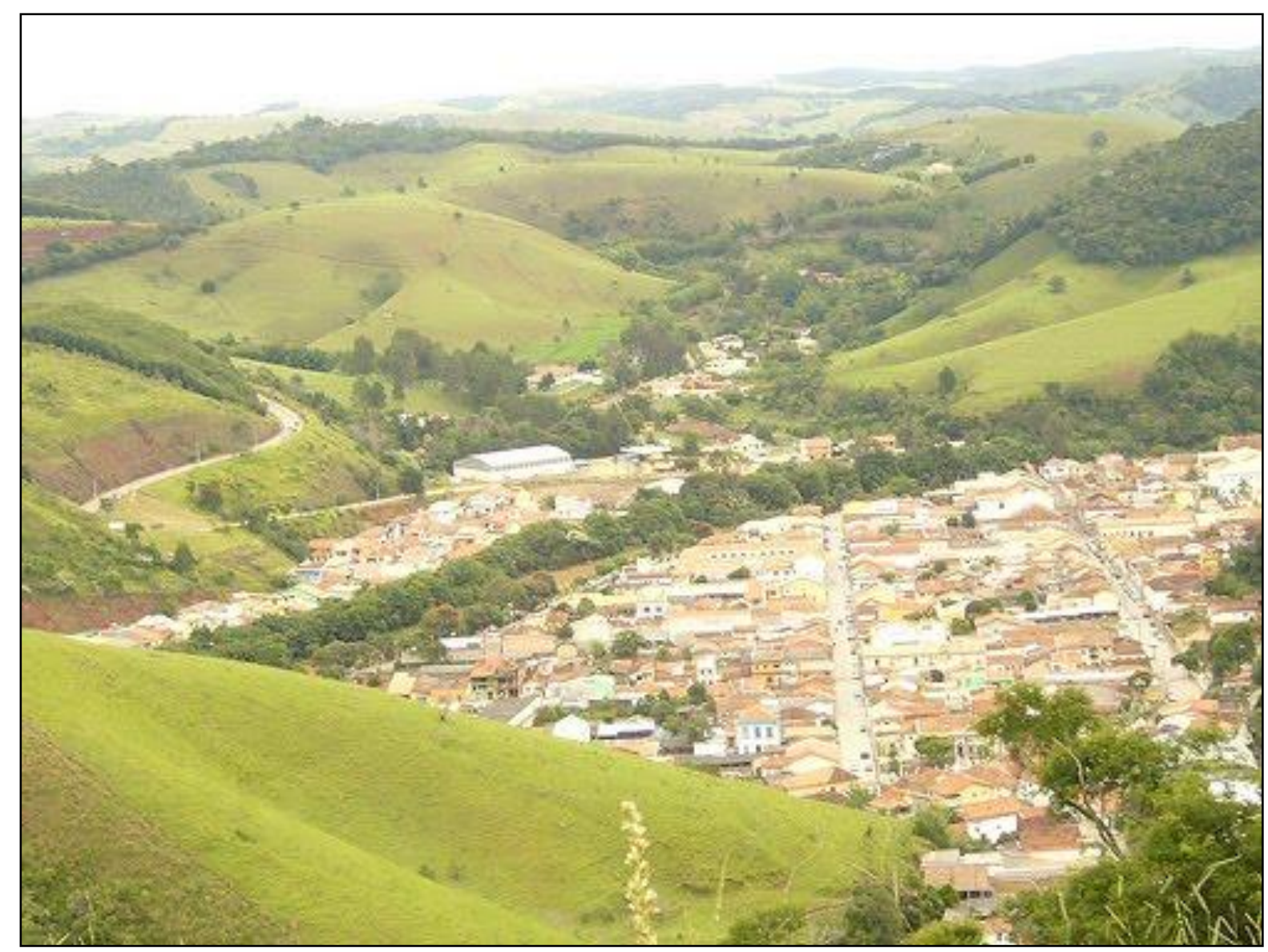

Figura 33 - Domínio de mares de morros Foto: Luiz Yassuda, 2009.

\footnotetext{
${ }^{40}$ Termo usado que significa as formas de 'meia laranja' que caracterizam o relevo de mares de morros.
} 
O Vale do Paraíba é marcado por grande disponibilidade hídrica e, com o escopo de proteger este recurso natural, criaram-se, através da Lei Estadual n ${ }^{\circ}$ 9.034, de 27 de dezembro de 1994, as Unidades de Gerenciamento de Recursos Hídricos (UGRHI). O município de São Luiz do Paraitinga encontra-se na UGRHI-2, Paraíba do Sul. A configuração das isoietas anuais médias indica que as precipitações mais elevadas, bem como as maiores contrastes de precipitação, estão associadas às serras da Mantiqueira (1.300 a $2.000 \mathrm{~mm}$ ) e do Mar (1.300 a $2.800 \mathrm{~mm}$ ). A UGRHU-2 está situada entre as duas serras e possui os mais baixos índices de precipitação. Porém, São Luiz do Paraitinga situa-se no inicio da Serra do Mar e sua precipitação oscila entre 1.200 e 1.300 mm, e exibe uma distribuição bastante uniforme (CBPS, 2009).

Devido ao relevo acidentado, o município é rico em recursos hídricos como cachoeiras, poços d'água, ribeirões, córregos e rios cristalinos.

O principal rio é o Paraitinga, que contorna a área urbana e possui sua bacia hidrográfica inserida na porção ocidental da Serra do Mar. Essa bacia se caracteriza por apresentar um relevo com elevada diversidade topográfica. Sua cabeceira de drenagem principal está localizada na Serra da Bocaina, em uma altitude próxima a 1.800 metros. O percurso do rio até o município de São Luís do Paraitinga é de cerca de 80 quilômetros, com desnível altimétrico de mais de 1.000 metros e com declividade média de 4,9 m/km. A partir da área urbana de São Luís de Paraitinga, o rio ainda percorre mais de $20 \mathrm{~km}$ até sua foz, no Reservatório de Paraibuna (SANTOS; DIAS; TARGA, 2009).

Além da bacia do rio Paraitinga, o município é banhado por outras quatro bacias hidrográficas, cujos principais rios são o rio Paraibuna, rio Chapéu, rio Turvo e rio Cachoeirinha, conforme exibidos no mapa seguinte (figura 34).

Elaborou-se este mapa por meio de feições lineares e variações na espessura das mesmas para representar os cursos d'água, com a intenção de evidenciar a relação de ordem ao hierarquizar os rios principais dos demais. Dentro de uma percepção visual seletiva, as bacias hidrográficas foram representadas por polígonos e a distinção de cores nos diversos matizes identifica as áreas das bacias. 


\section{SÃO LUIZ DO PARAITINGA (SP): REDE HIDROGRÁFICA}

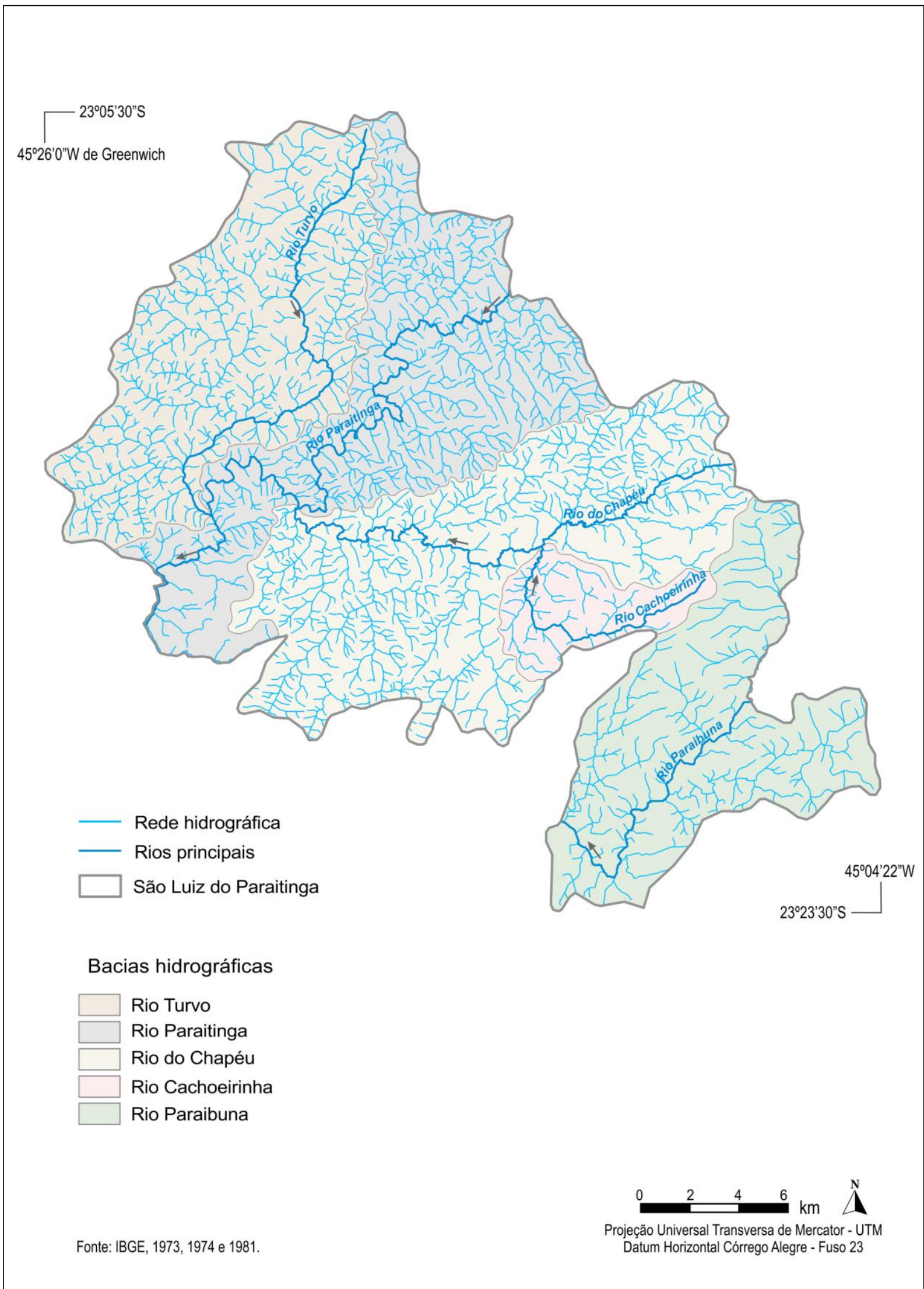

Figura 34 - Mapa hidrográfico de São Luiz do Paraitinga (SP) cujos rios são representados por linhas ordenadas e as bacias por áreas coloridas. 
O município de São Luiz do Paraitinga, originalmente coberto pela floresta Atlântica, testemunhou o uso intensivo da terra que resultou em uma paisagem onde predominam pequenos fragmentos de floresta secundária e pastagens. A configuração da cobertura vegetal, em especial por meio das informações gráficas foi extraída dos estudos realizados em 2008 pelo Instituto Florestal - IF “Mapa Florestal dos Municípios de São Paulo”. O IF elaborou um inventário da cobertura vegetal no Estado de São Paulo e disponibilizou os mapas temáticos por abrangências municipais. O mapa a seguir (figura 35) representa a cobertura vegetal e o uso da terra de São Luiz do Paraitinga, com base nos estudos do IF. As bases cartográficas adquiridas estavam em formato digital com seus devidos atributos agregados, porém, adaptouse a escala de acordo com os demais mapas deste capítulo.

O uso da terra está, amiúde, associado aos aspectos físicos, em especial, ao relevo. As vertentes de distintas exposições e diferenças no aporte de energia solar são determinantes para o desenvolvimento das florestas nativas, assim como a produtividade de gêneros cultivados, e repercutem nas escolhas dos agricultores na utilização das terras. Dessa forma, os fragmentos do uso da terra são parcialmente influenciados pelas intervenções humanas, que, muitas vezes, dependem da topografia e outras variáveis naturais, configurando, assim, uma paisagem híbrida (MELLO, 2009).

A economia do café deixou muitas marcas na paisagem, modificando os aspectos paisagísticos originais do território. Alinhando-se nas encostas mais ou menos íngremes, substituiu, algumas vezes, culturas anuais, como o milho, ou eliminou capoeiras. $\mathrm{O}$ fato mais importante é que o café acelerou a destruição das matas, em busca de solos mais ricos.

Diante disso, a paisagem de São Luiz do Paraitinga testemunhou o uso intensivo da terra no Vale do Paraíba, que foi barrado pelas escarpas íngremes da Serra do Mar voltadas para o Oceano Atlântico, no litoral paulista. Observa-se no mapa que quanto mais distante da Serra do Mar, em direção à Taubaté e ao Vale do Paraíba (norte-noroeste), mais escassas e fragmentadas tornam-se as matas (formações nativas, com componente arbóreo dominante em qualquer estágio de regeneração), fortemente concentradas na extremidade sudeste do município, que inclui o Núcleo Santa Virgínia do Parque Estadual da Serra do Mar.

No restante do município predominam as pastagens (pastos mantidos para uso ou com histórico recente de uso agropecuário, com estrato herbáceo dominante, podendo incluir arbustos de até três metros), as capoeiras (mata secundária em estágio inicial de regeneração, sem componente arbóreo dominante), os reflorestamentos, em especial, os plantios de eucalipto com sub-bosque ausente ou pouco denso (situados, sobretudo, no extremo norte, centro e alguns fragmentos ao sul, na Serra do Mar) e a área urbanizada. 
SÃO LUIZ DO PARAITINGA (SP): COBERTURA VEGETAL E USO DA TERRA

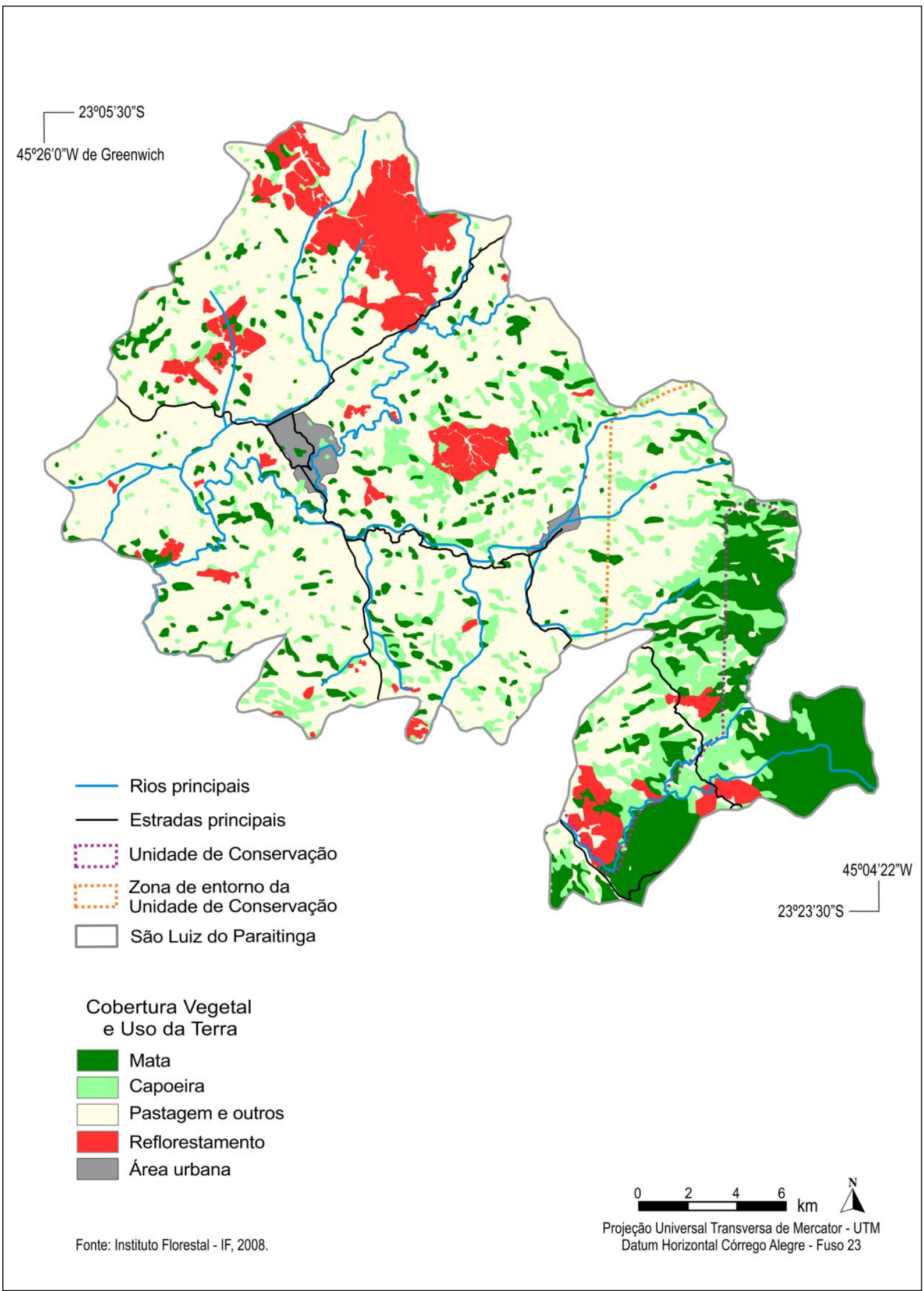

Figura 35 - Mapa de cobertura vegetal e uso da terra de São Luiz do Paraitinga (SP) representado por áreas dissociadas pela variável cor. 
Optou-se, no mapa anterior, por representar as áreas com mata na cor verde escuro, a fim de transmitir ao leitor a concentração de uma vegetação densa e usou-se tonalidades mais claras desse verde, conforme a vegetação se degrada no nível de capoeiras e pastagens. Porém, as cores quentes, neste caso, o vermelho, é muito utilizado para apontar áreas desmatadas e atualmente exploradas com reflorestamento. Observa-se, outrossim, que há informações seletivas no modo de implantação linear, como as drenagens e rodovias.

De acordo com os dados consolidados do censo agropecuário dos anos de 2007 e 2008, disponibilizados pelo Projeto LUPA ${ }^{41}$, no município de São Luiz do Paraitinga existe em torno de 1.066 ha de área agricultável (64,9 ha são culturas perenes e 1.001,4 ha são culturas temporárias), $27.127,8$ ha de área com pastagens, $7.841,6$ ha de área com reflorestamento e 14.277 ha de área com vegetação nativa.

Nos últimos anos, o uso da terra no município tem sofrido sensíveis alterações. Tal fato é constatado ao comparar os dados fornecidos pelo Projeto LUPA dos anos 2007/2008 com os anos de 1995/1996. Em relação ao período anterior, a área agricultável obteve uma queda de $48,4 \%$. A área com pastagens também sofreu queda, porém, pouco considerável. Já as áreas de reflorestamento e vegetação natural se expandiram. Considera-se que a vegetação natural obteve um acréscimo relevante, cerca de 51,3\%. O gráfico 10 expressa os dados comparativos dos períodos.

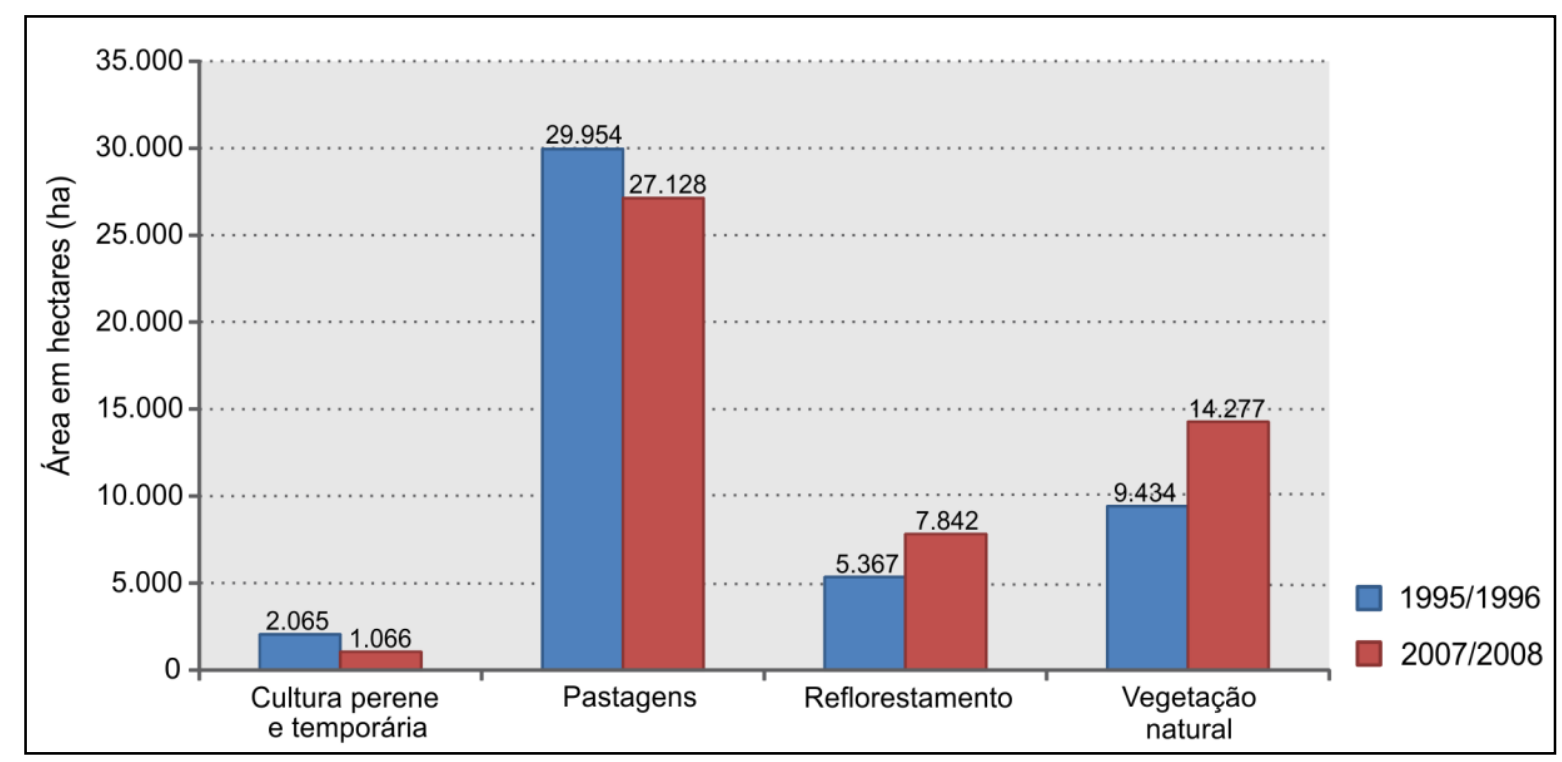

Gráfico 10 - Comparativo dos dados censitários agropecuários, 1995/1996 e 2007/2008 Fonte: Projeto LUPA

\footnotetext{
${ }^{41}$ Levantamento Censitário das Unidades de Produção Agropecuárias. Disponível em: <http://www.cati.sp.gov.br/projetolupa/index.php>. Acesso em 22 de março de 2013.
} 
É relevante, mais uma vez, apontar na configuração da paisagem uma origem híbrida, determinada pelos atributos sociais e naturais associados. No município de São Luiz do Paraitinga, a estrutura dos fragmentos de uso da terra e cobertura do solo presentes na paisagem estão correlacionadas, em parte, com as intervenções humanas. Diante disso, tornase relevante a elaboração de mapas temáticos com indicadores e variáveis demográficas.

Neste campo, decidiu-se por representar graficamente os dados estatísticos da distribuição populacional, disponibilizados pelo IBGE (2010) por áreas do setor censitário. São Luiz do Paraitinga é dividido por 26 setores, apenas 11 deles se encontram na zona urbana central (sede do município).

A ocupação do território luizense, nas últimas décadas, foi caracterizada por uma grande perda de população rural e uma concentração populacional acentuada na cidade. Diante desta afirmação, o mapa a seguir (figura 36) aponta forte comparecimento de habitantes na área urbana central e o vazio demográfico nas áreas rurais. Nota-se que o perímetro urbano principal é relativamente pequeno, porém, com presença marcante da população e área reduzida, acarretando uma alta densidade demográfica. Observa-se, outrossim, que há um significante aglomerado populacional na porção sudeste, na parte urbana do bairro de Catuçaba.

O restante da concentração populacional aloja-se, em especial, nos setores censitários limítrofes ao centro urbanizado da cidade. Já na porção leste e sul do município, a presença da população é baixa devido às altas altitudes, vegetação fechada e densa das áreas de proteção ambiental.

Diante das particularidades expostas, no mapa subsequente foram abordados três temas correspondentes. Para os tipos de ocupação, utilizaram-se as hachuras de linhas inclinadas com a finalidade de representar o perímetro urbano e uma discreta cor verde para o perímetro rural. A população total de cada setor censitário ${ }^{42}$ foi representada por meio dos polígonos de tamanhos proporcionais, que têm a capacidade de expressar informações quantitativas, isto é, os círculos menores exibem as áreas com baixa população, e aumentam, de forma proporcional, conforme se eleva o número de habitantes.

A cor de cada círculo interpreta a respectiva densidade demográfica. Esta foi representada por ordem visual crescente de cores quentes, sequência escalonada que segue do claro para o escuro, ou seja, cores amarelas para baixas densidades demográficas, passando pelo laranja e até atingir o vermelho escuro nos perímetros mais densos.

\footnotetext{
${ }^{42}$ Os setores censitários e as variáveis contidas na área central urbana foram unidas por meio da ferramenta "merge" a fim de facilitar a representação do mapa impresso na vigente escala.
} 
SÃO LUIZ DO PARAITINGA (SP): OCUPAÇÃO E DISTRIBUIÇÃO POPULACIONAL

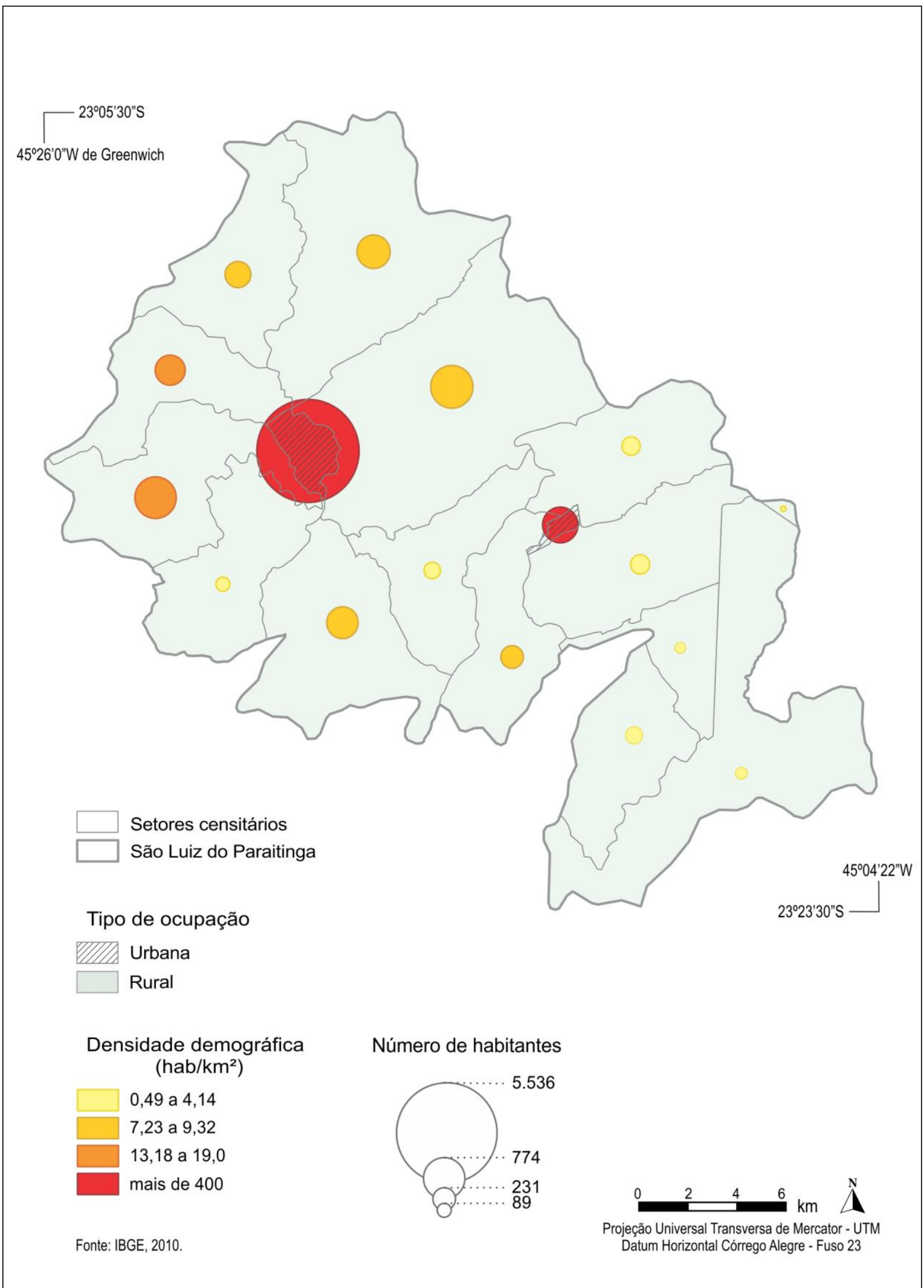

Figura 36 - Mapa da ocupação e distribuição populacional de São Luiz do Paraitinga (SP) por setor censitário, representado por círculos de tamanhos proporcionais e a respectiva densidade demográfica por ordem visual de cores quentes. 
O principal acesso ao município é feito pela Rodovia Osvaldo Cruz (SP-125) que liga a cidade de Taubaté com Ubatuba. Por este percurso, depara-se com a maior concentração populacional do município. O tráfego é intenso nos finais de semanas e feriados, quando prevalecem os veículos de passeio. Revela-se de pequena monta a utilização do meio de transporte coletivo.

Além da rodovia SP-125, apenas duas estradas secundárias são asfaltadas. As vias de rolagem que percorrem o território luziense são, na maioria, de terra. No mapa a seguir foram selecionadas as vias relevantes para acessibilidade do município e representadas por meio de linhas com variação de espessura associada à variação de cor no intuito de mostrar a hierarquia e tipologia das vias elegidas.

Agregaram-se, nesta representação, os meios de hospedagens situados na porção externa da área urbanizada. O levantamento destes equipamentos foi realizado através de pesquisas prévias na internet (sites de agências de viagens, meios de hospedagens, Google Earth, etc.) e, a posteriori, uma pesquisa em campo com o escopo de detectar os pontos não encontrados por intermédio do GPS, modelo "Garmin eTrex 30". Ressalta-se que neste procedimento configurou-se a mesma projeção cartográfica da base cartográfica. Dessa forma, foi possível obter as coordenadas dos pontos faltantes, importá-los para o ArcGis, inseri-los no mapa e, por último, agregar ao mapa de sistema viário.

O resultado deste agrupamento proporciona uma nítida visão da distribuição espacial dos tipos de meios de hospedagem. Estes estão representados por signos pontuais e diferenciados pela variável visual cor. Este mapa é relevante porque identifica a ocorrência de meios de hospedagens instalados próximos às estradas e nos arredores da área urbanizada, conforme mostra a figura 37. 
SÃO LUIZ DO PARAITINGA (SP): SISTEMA VIÁRIO E MEIOS DE HOSPEDAGEM NAS ÁREAS RURAIS E NATURAIS

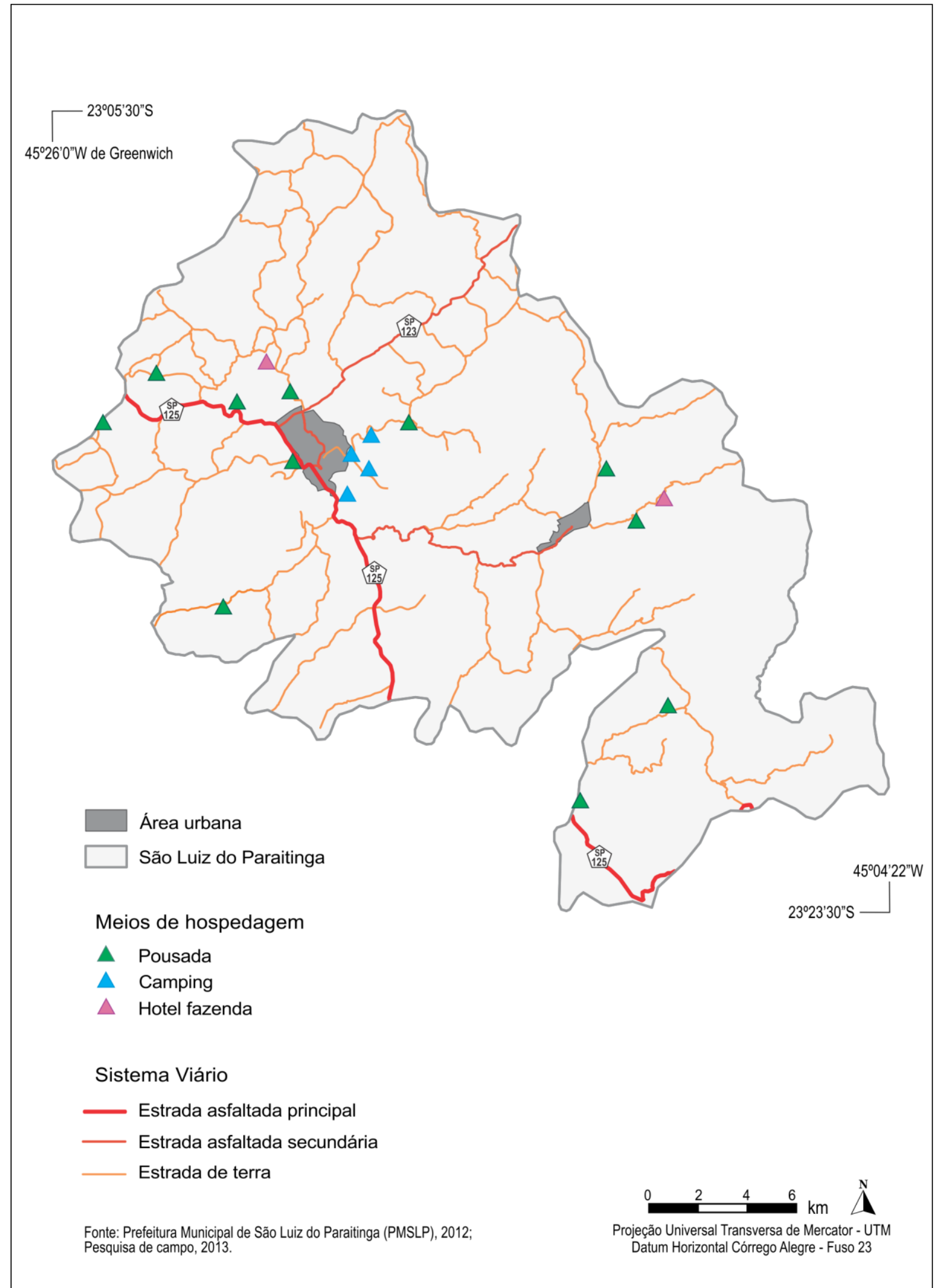

Figura 37 - Mapa do sistema viário e meio de hospedagem nas áreas rurais de São Luiz do Paraitinga (SP) cujas estradas são hierarquizadas pela espessura das linhas e cores ordenadas e, as hospedagens dissociadas por feições pontuais coloridas. 
É admissível inserir, dentre os mapas temáticos analíticos, um mapa de alguns lugares com potencialidades e/ou demais atrativos turísticos implementados, como a presença de fazendas históricas e cachoeiras. As primeiras, como já mencionado, são antigas residências dos barões da monocultura cafeeira no século passado e as cachoeiras provêm, em especial, da forma encachoeirada do perfil longitudinal dos rios e respectiva abundância de recursos hídricos, em um contexto de relevo com média e alta declividade.

Métodos semelhantes ao descritos no mapa anterior, com auxilio do GPS e assistência de um morador, foram utilizados para localizar as principais fazendas e cachoeiras. Estas estão representadas por signos pontuais com variação de forma e cor. Exibiram-se as estradas, mais uma vez, de maneira ordenada, hierarquizada pela combinação harmônica das cores e espessura das linhas (figura 38).

Dessa forma, identificou-se que as fazendas representadas estão situadas próximas às principais estradas. Porém, há uma concentração das mesmas na bacia do rio do Chapéu, mais precisamente ao longo eixo que liga o centro da cidade ao pequeno bairro urbano de Catuçaba e no entorno deste.

É na bacia do rio do Chapéu que também estão localizadas algumas das principais cachoeiras. No entanto, a afluência destas acontece ao longo do rio Paraibuna, onde o relevo é mais montanhoso e alguns pontos são bastante acidentados. 
SÃO LUIZ DO PARAITINGA (SP): PRINCIPAIS FAZENDAS E CACHOEIRAS

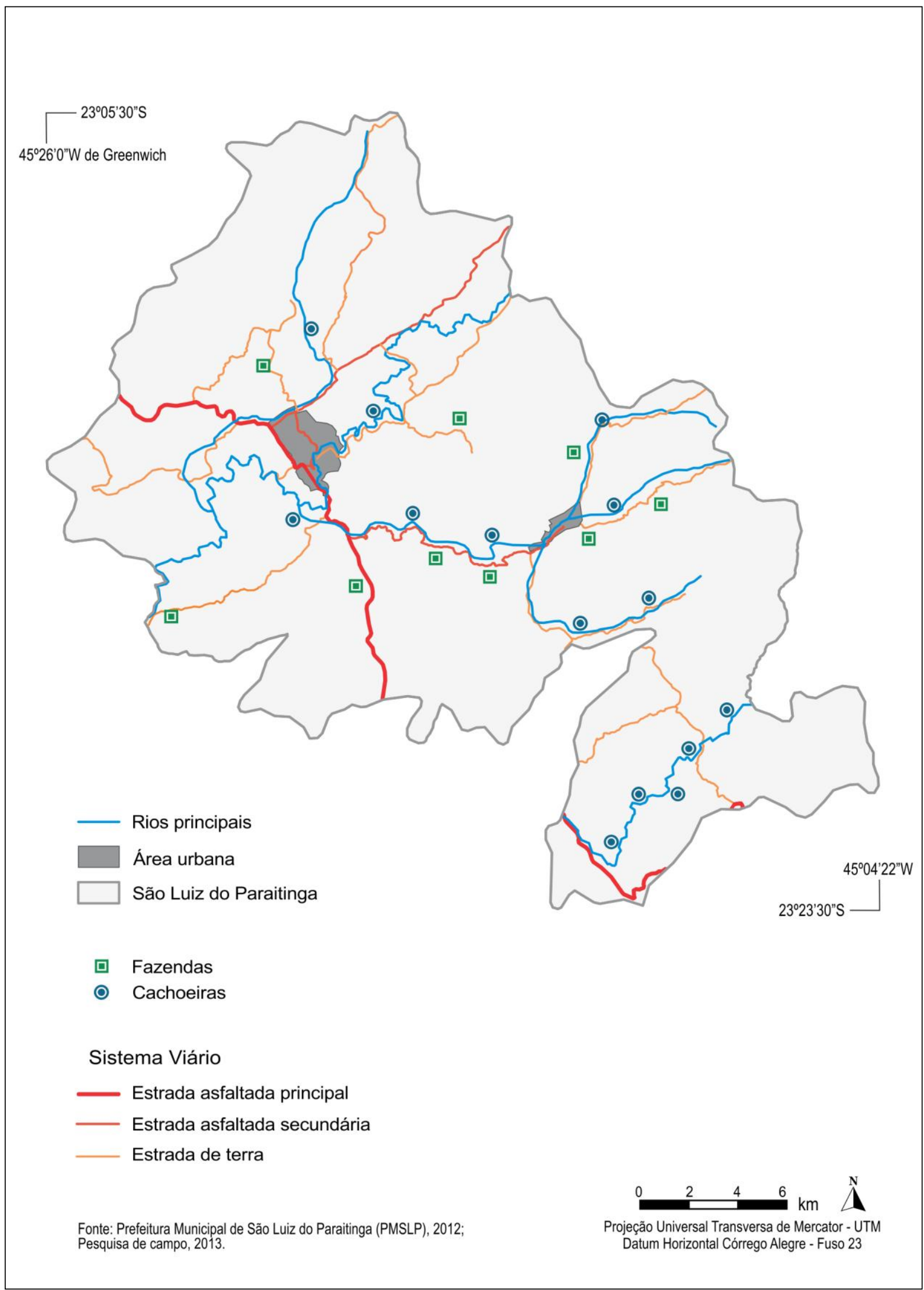

Figura 38 - Mapa das principais fazendas históricas e cachoeiras de São Luiz do Paraitinga (SP) representadas por signos pontuais selecionados pela variação visual de forma e cor. 
Para o quadro urbano, em particular, alterou-se a escala com a intenção de avaliar os registros espaciais notáveis da cidade. A base cartográfica e dados referentes às edificações, disponibilizados pelo IPHAN, serviu de aporte para se elaborar o mapa de uso do da área urbana.

Este material foi adquirido em arquivo de formato dxf (Drawing Exchange Format), usualmente utilizado no software AutoCad. Algumas camadas foram exportadas para shapefile e o mapa foi adaptado no software ArcGis conforme a necessidade desta pesquisa.

Pode-se dizer que o uso do solo é uma combinação de um tipo de uso (atividade) e de um tipo de assentamento (edificação). No mapa a seguir (figura 40), são apresentadas as diversas categorias de uso, como o residencial, comercial, misto, serviço, entre outros, dos imóveis situados nos centros históricos I e II de São Luiz do Paraitinga.

As edificações representaram-se pela manifestação zonal (áreas), de maneira seletiva por meio da combinação contrastante e isenta do ordenamento harmônico das cores. Dessa forma, o mapa de uso do solo torna-se um importante construto capaz de mostrar, graficamente, as funções de cada edifício diante da constante dinâmica espacial. Observa-se que no centro urbano do município há o predomínio do uso residencial (cor amarela), fato bastante benéfico para um lugar turístico.

Muitos imóveis que foram residências, hoje são estabelecimentos comerciais ou ocupadas por prestadores de serviços, como a casa do professor Aziz Nacib Ab'Saber, onde, atualmente, funciona uma barbearia. Atenta-se, contudo, que nestes centros históricos, a população não foi totalmente expulsa. A circulação de moradores nos arredores da área central dá vida e aproxima a cultura local dos turistas. 


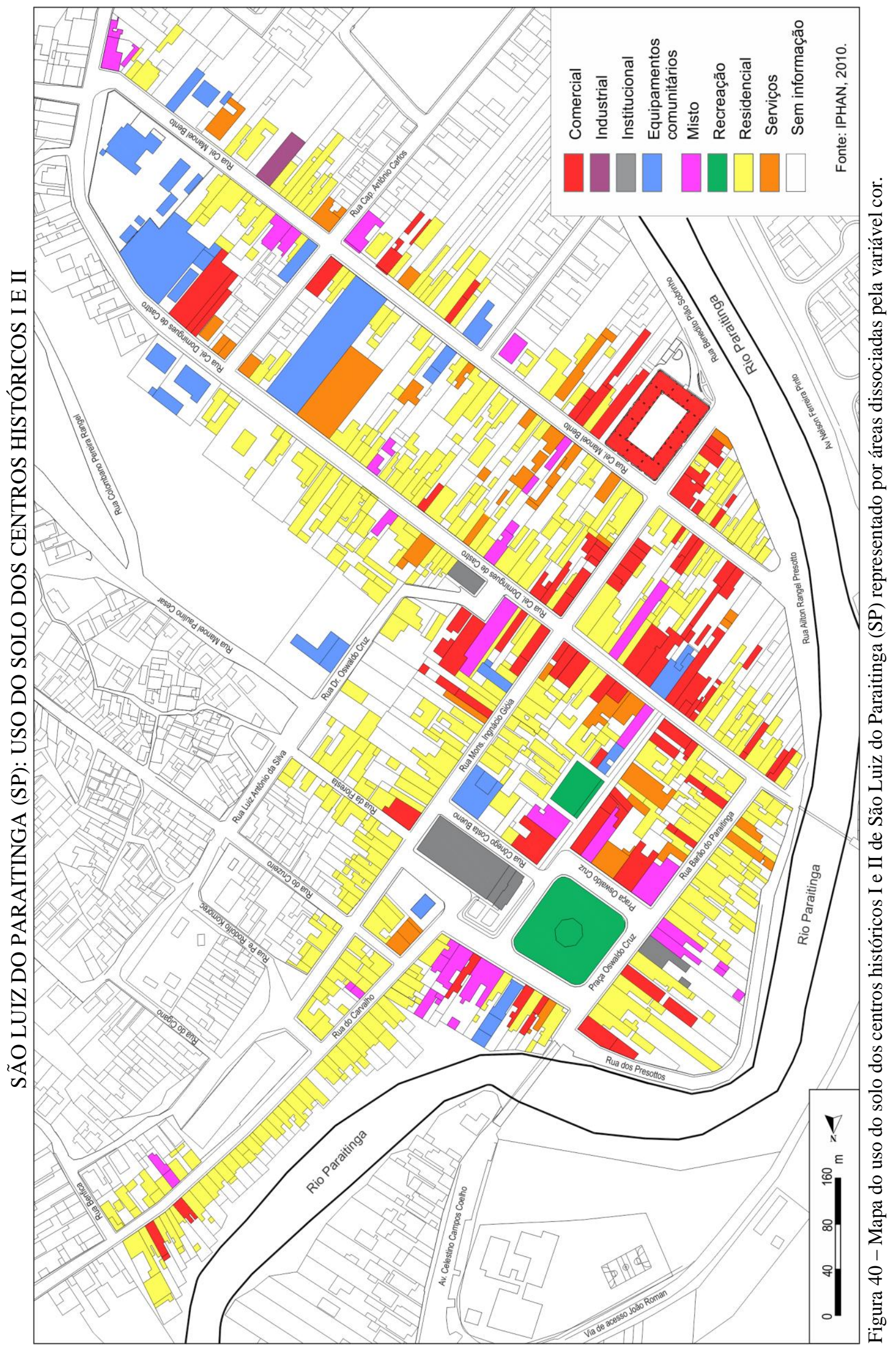


Apesar de manter a escala dentro de um quadro urbano, procedimentos distintos aos realizados na elaboração do mapa anterior serviram para identificar infraestruturas turísticas da área central do município. Neste caso, extraíram-se imagens aéreas do software Google Earth, retirando todas as camadas extras possíveis contidas no programa (ex. divisas, rodovias, pontos de interesse, terreno etc.). A escala das imagens coletadas é compatível com a altura de voo de aproximadamente 600 metros e em seguida foram georreferenciadas, com auxílio do ArcGis. Houve, assim, a produção de um mosaico com todas elas, tornando-se uma única imagem aérea da área selecionada.

Diante desta imagem georrefenciada, ainda em ambiente SIG, adicionaram-se três novas categorias de feições pontuais unidas por um banco de dado descrito pelos respectivos atributos (características). São elas: os principais atrativos turísticos urbanos, principais equipamentos (públicos e privados) e meios de hospedagens (campings e pousadas) (figura 40). Para localizar e inserir os pontos não se tornou necessário a utilização do equipamento de GPS, devido aos conhecimentos prévios da pesquisadora, facilitados pelo uso da imagem.

As categorias foram distinguidas por meio das variáveis formas e cores, neste caso, imune do nível ordenado, o que proporcionou uma avaliação qualitativa do mapa. Nota-se que os atrativos turísticos e os equipamentos são identificados por números e, assim, torna-se possível avaliar como os pontos de grande relevância voltados para a prática do turismo (todos do patrimônio cultural arquitetônico) encontram-se espacialmente distribuídos. 


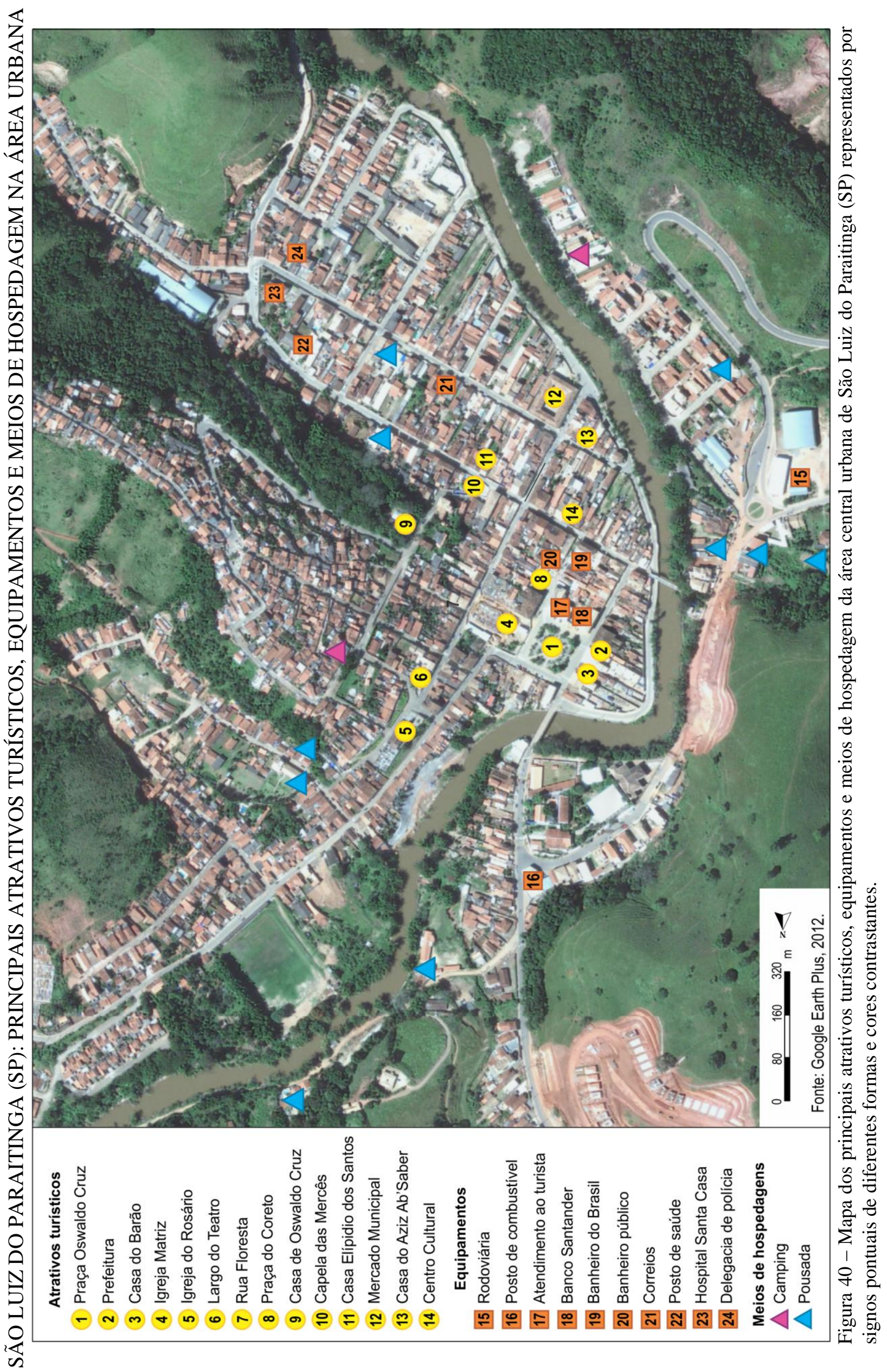


Buscou-se, destarte, realizar um levantamento da distribuição espacial de diversos temas sociais e ambientais, vinculados ao patrimônio cultural de São Luiz do Paraitinga, com a finalidade de fornecer informações representadas em mapas temáticos, objetivando definição de locais e roteiros, e ações de desenvolvimento que possam vir a ser executadas pelas autoridades competentes.

\subsection{Cartografia de síntese com delimitação e identificação dos tipos de paisagens}

Na Geografia, a cartografia de síntese não é algo recente. A cartografia de síntese surge entre o fim do século XIX e início do século XX, com Paul Vidal de La Blache ${ }^{43}$ e a escola francesa, para participar do estudo, sobretudo o da representação da paisagem (MORAES, 2003).

A partir daí, a síntese tornou-se uma necessidade. Deve ser processada de maneira tal a fazer emergir novas configurações. Estas, porém, não devem ser apenas o resultado de uma simples soma das configurações elementares. Como resultado, obter-se-á uma visão global, holística e integrada da realidade.

Como visto neste trabalho, uma forma de se chegar à elaboração de um mapa síntese é proceder a uma representação integrada a partir da sobreposição de dados e informações em nível analítico. Para tanto, os procedimentos necessitam ir além da soma dos dados. Estes necessitarão de explicações que devem ser buscadas por meio de questionamentos tais como: como fazer uma leitura dos recursos hídricos sem informações sobre o relevo? Como identificar a relação ou uso da terra e cobertura vegetal sem informações sobre o relevo, sistema viário e distribuição da população? Como perceber os potenciais e atrativos turísticos naturais sem saber como o relevo e/ou hidrografia estão estruturados? Ou, ainda, como compreender a dinâmica do turismo do patrimônio cultural urbano sem informações sobre sua história e infraestrutura básica?

O entendimento das relações entre os elementos da paisagem é realizado de forma mais fácil quando se parte do princípio de que elas (as relações) são visualizadas. Nesse sentido, constitui-se um mapa síntese concreto, capaz de seguir as orientações ancoradas na

\footnotetext{
${ }^{43}$ Geógrafo francês que definiu o objeto da geografia como a relação homem natureza, na perspectiva da paisagem e colocou o homem como um ser ativo, que sofre influência do meio, porém atua sobre este, transformando-o. Mostrou como as paisagens de uma região são o resultado das superposições, ao longo da história, das influências humanas e dos dados naturais.
} 
concepção da representação gráfica e, como tal, apresentar características que só são compreendidas com base em uma leitura da paisagem.

Diante desta fundamentação, elaborou-se o mapa síntese do município de São Luiz do Paraitinga, representativo dos tipos de paisagens. Adaptaram-se todos os mapas analíticos a uma escala pertinente aos conteúdos trabalhados, vislumbrando unidades espaciais, que permitiram a percepção do agrupamento delas em função das respectivas características singulares. Para atingir este resultado utilizou-se os mapas analíticos digitais, em especial as variáveis do relevo, que facilitaram e tornaram plausíveis deste modo, a delimitação e a identificação de unidades taxonômicas no território estudado, as quais foram vetorizadas em ambiente SIG.

Como resultado desta síntese, revelou-se que o território municipal mostrou uma compartimentação em sete tipos de paisagem. São elas:

TIPO 1 - Paisagem dos altos espigões da Serra do Campo Grande, incorporando a nascente do rio Cachoeirinha, do rio Chapéu e outros rios encachoeirados, completando-se por relevo com altitudes elevadas (entre 1.200 e 1.600 metros) e topos salientes que permitem uma feérica visibilidade para as cimeiras do reverso da Serra do Mar. Presença de fragmentos florestais residuais e capoeiras ombrófilas alto-montanas (Mata Atlântica) na porção centrosul e predomínio de pastagens, lavouras temporárias na porção norte. É uma área rural de especial interesse de preservação ambiental, haja visto que já está inserida dentro dos limites da Zona de Amortecimento da Unidade de Conservação da Serra do Mar. Possui o menor efetivo de habitantes do município.

TIPO 2 - Paisagem de relevo montanhoso, com altas altitudes, exibindo um inusitado alinhamento de espigão, cortado pela passagem do vale do rio do Chapéu. Presença significativa de reflorestamento (plantação de eucalipto) intercalada pela vegetação secundária (capoeiras) composta por espécies nativas em regeneração e pequenos fragmentos de Mata Atlântica. Na porção sul, há propriedades rurais, predomínio de pastagens e de campos naturais utilizados para pecuária e para a agricultura de subsistência. Número pouco expressivo de população residente.

TIPO 3 - Paisagem de reverso e topos da escarpa da Serra do Mar composta por alinhamentos paralelos de morros com altas altitudes, com destaque para o relevo com média declividade nas vertentes dissecadas do vale do rio Paraibuna, o que propicia fortes 
corredeiras em seu curso d'água e presença de cachoeiras nos seus afluentes. Inclui a unidade de preservação protegida, patrimônio natural e da humanidade, com acentuada presença da Mata Atlântica nativa composta pela floresta ombrófila densa, além de extensas áreas cobertas por capoeiras em estado avançado de regeneração, existência de nichos de reflorestamento nas bordas das estradas e pequenas propriedades rurais, com número bastante reduzido de habitantes.

TIPO 4 - Paisagem das vertentes moderadamente dissecadas do vale do rio do Chapéu articuladas com as de parte do vale do rio Cachoeirinha e serras alongadas, com altitudes médias (entre 1.000 e 1.100 metros). Área com fragmentos disseminados de vegetação secundária em regeneração, pequenos nichos de mata nativa, predomínio de campos naturais empregados para pastagens e poucas áreas utilizadas pela agricultura de subsistência. Presença de algumas fazendas históricas e casas tradicionais, situadas no bairro de Catuçaba e no eixo de ligação (estrada municipal) entre as áreas urbanas. Número da população residente pouco significante.

TIPO 5 - Paisagem de relevo predominante formado por colinas suaves, incorporando a nascente do rio Turvo, com altitude média de 900 metros. Presença de pouca cobertura vegetal e área extensa de reflorestamento (plantação de eucalipto) nas vertentes norte. Predomínio de pastagens e campos naturais utilizadas para práticas agrícolas (modestas lavouras permanentes, com cultivos de milho e leguminosas) e pecuária. Área ocupada por significativa quantidade de pequenas propriedades rurais e expressivo número de população residente.

TIPO 6 - Paisagem do vale do rio Paraitinga com leves corredeiras e suaves cachoeiras, ladeado por médias e baixas vertentes com 800 metros de altitude, envolvendo os fundos de vales, ocupados por pousadas emolduradas pelo relevo de mar de morros e com presença significante de reflorestamento na porção norte. Predomínio de lavouras temporárias e agricultura de subsistência associada às manchas de pastagens e campos naturais, com pequenos fragmentos de Mata Atlântica e vegetação secundária em estágio de regeneração na porção centro-sul. Área dividida pela estrada estadual SP-123 e com permanência de um acentuado número de habitantes por ser zona de transição para a área urbana. 
TIPO 7 - Área urbana incrustada na porção de mais baixa altitude, formada pela planície do vale do rio Paraitinga e cercada pelo relevo de mar de morros. Predomínio de edificações arquitetônicas históricas e alguns nichos de vegetação secundária em estágio de regeneração de espécies nativas. Área inteiramente tombada e patrimônio cultural, com forte presença de uso residencial, comercial e prestadores de serviço. Centro das festas tradicionais e maior densidade populacional do município.

Para cada área descrita, atribuiu-se uma característica específica com o intuito de estabelecer a organização da representação em duas ordens visuais opostas, desde as cores frias até as cores quentes - passando pelo amarelo, que se coloca nas situações intermediárias, conforme os tipos de paisagem se estendem dos conjuntos espaciais das elevadas altitudes com potencialidades naturalísticas de nota para as mais baixas planícies com sensíveis alterações da naturalidade.

Mesmo que a comunicação, mediante este mapa síntese deva ser rigorosamente estruturada no sistema semiológico gráfico monossêmico, as figuras serão bem-vindas para alcançar resultados positivos na recepção da mensagem gráfico-visual pelos turistas, planejadores e demais usuários. Optou-se, assim, por destacar na legenda algumas imagens fotográficas para cada tipo de paisagem. São imagens figurativas de características polissêmicas, porém capazes de salientar, em linhas gerais, o potencial da respectiva área retratada correspondente a cada rubrica da legenda, conforme mostra a figura 41 : 
SÃO LUIZ DO PARAITINGA (SP): TIPOS DE PAISAGEM, 2013
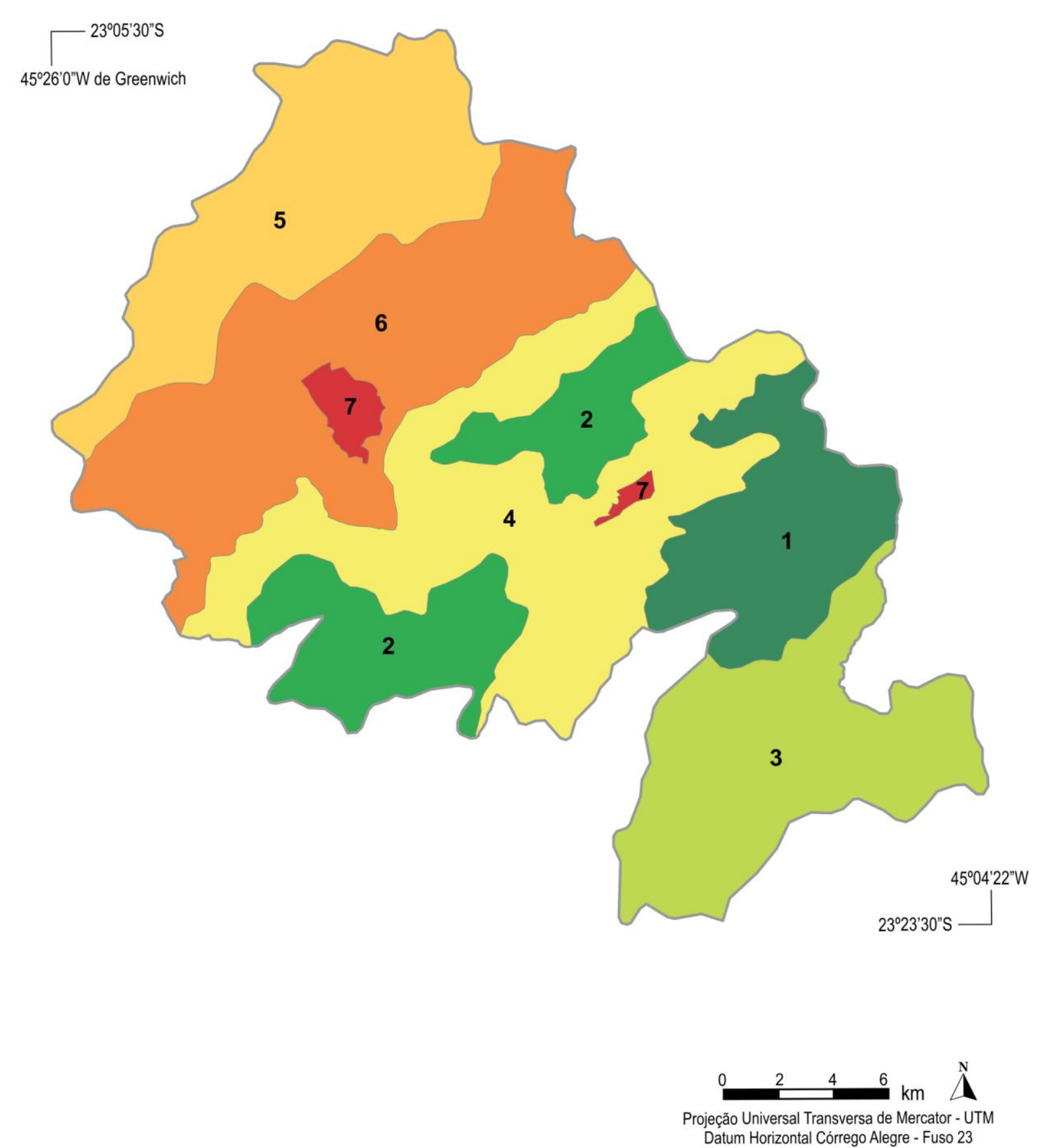
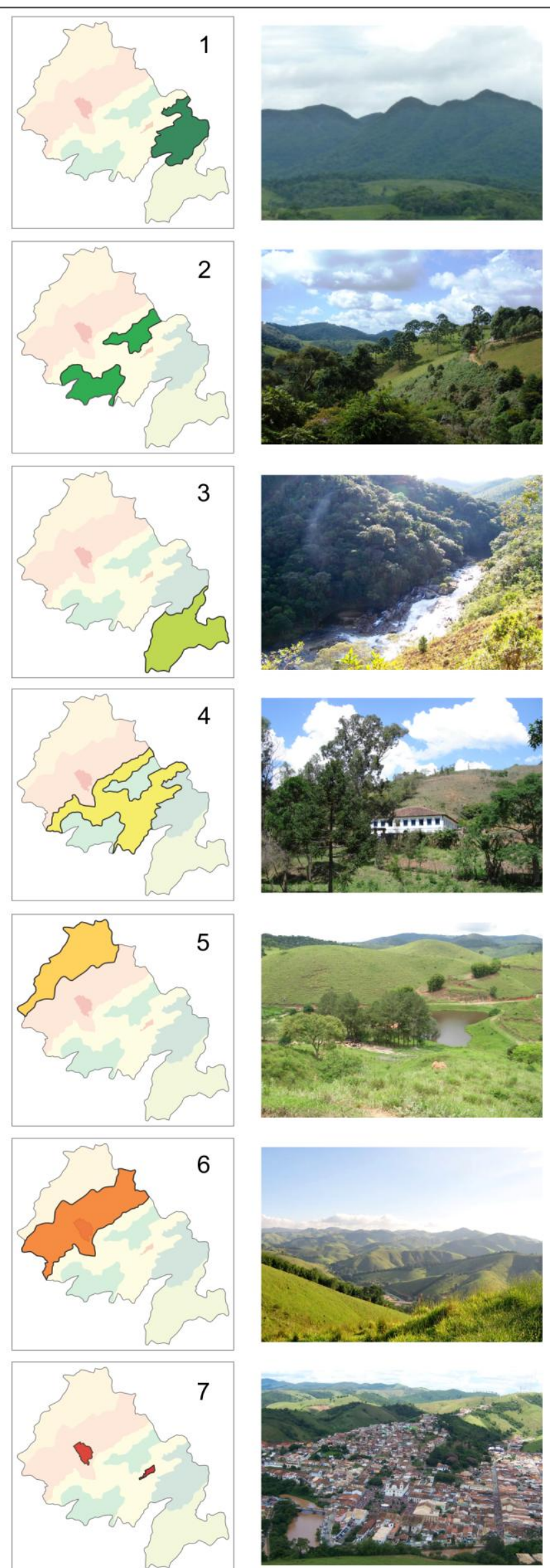

\section{TIPO 1}

Paisagem dos altos espigōes da Serra do Campo Grande e rios encachoeirados, completando-se por relevo com altitudes elevadas e topos salientes. Forte presença norte. E uma area natura inserica dentro dos limites da Zona de Amortecimento da Unidade de Conservação da Serra do Mar e possui o menor efetivo de habitantes
do municíio.

TIPO 2

Paisagem de relevo montanhoso, com altas altitudes, exibindo um inusitado significativa de espigäo cortado pela passagem do vale do rio Chapéu. Presença secundárias compostas por espécies nativas em regeneracăão e fragmentos de Mata Attântica. Na porção sul há propriedades rurais, predominio de pastagens e campos naturais utilizados para agricultura de subsistência e pecuária. Número

TIPO 3

Paisagem do reverso e topos da escarpa da Serra do Mar composta por morros dissecadas do vale do rio Paribuna o qu propicia fortes correderes das vertentes em seus afluentes. Inclui a unidade de preservação protegida, patrimônio natural da humanidade com acentuada presença da Mata Attântica, alem capoeiras em estado avançado de regeneraçao, existencia de nichos de reflorestamento nas

TIPO 4

Paisagem das vertentes moderadamente dissecadas do vale do rio do Chapéu articuladas com partes do vale do rio Cachoeirinha e serras alongadas, com pequenos nichos de mata nativa, prevomini de pastagens e poucas áreas utilizadas pela agricutura de subsistência. Presença de fazendas historicas e casas tradicionais situadas no bairro de Catuçaba e eixo de ligação entre as áreas urbanas. População residente pouco signifcante.

TIPO 5

aisagem de relevo predominante formado por colinas suaves, incorporando a reflorestamento (nentaco e campos naturais utilizadas para práticas agricolas (lavouras permanentes, com cultivo de milho e leguminosas) e pecuária. Area ocupada por pequenas propriedades rurais e expressivo número de população residente.

TIPO 6

Paisagem do vale do rio Paraitinga com leves corredeiras e suaves cachoeiras, uras temporárias associadas às manchas de pastagens $\mathrm{e}$ campos naturais, com fragmentos de Mata Atântica $\mathrm{e}$ capoeiras em estágio de regeneração na porção centro-sul. Area dividida pela TIPO 7

aisagem urbana incrustada na porção de mais baixa altitude formada pela planicie

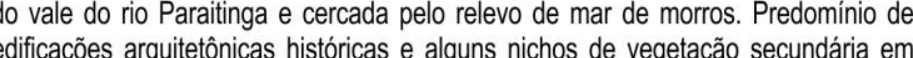
estágio de regeneração de espécies nativas. Área inteiramente tombada e patrimônio cultural, com forte presença de uso residencial, comercial e prestadores de serviço. Centro das festas tradicionais e maior densidade populacional do municíioi. 
A partir das características atribuídas para cada tipo de paisagem do território luizense, é possível destacar uma imensa área provida de aspectos com particularidades rurais e naturais. A tendência destes recursos em se transformarem em atrativos turísticos sinaliza a vocação do município não apenas para o turismo com usufruto do patrimônio arquitetônico no perímetro urbano, mas, igualmente, para a prática do turismo em unidades munidas de patrimônio natural. Tal fato, na atualidade, tem se destacado entre as diversas possibilidades turísticas no território brasileiro. De acordo com Cruz (2003, p.62) "a diversidade natural dos ambientes brasileiros faz do Brasil um país com grande potencial para as práticas de turismo de natureza".

A combinação do mapa de relevo com o mapa de recursos hídricos indica peculiaridades que compõe parte dos atrativos turísticos voltado à natureza. $\mathrm{O}$ rio Paraibuna, por exemplo, possui alto volume de água e encontra-se em uma área de relevo fortemente ondulado e montanhoso, com alguns pontos de significantes declividades e até saltos. Tais características propiciam um gradiente ${ }^{44}$ que acelera as corredeiras do rio, isto é, uma combinação de recursos naturais ideal para a prática do rafting. O contrário pode ser visto no rio Paraitinga, cujas águas menos agressivas e o relevo pouco acidentado permitem a prática do ducking ${ }^{45}$. Já as áreas com maiores altitudes, declividades acentuadas e presença de cabeceiras, originam as cachoeiras, ambiente propício para a prática de cascading.

Nada obstante São Luiz do Paraitinga ostentar grande potencial turístico, respaldado nos seus aspectos naturais e rurais, a maioria dos atrativos ainda se concentra no centro histórico da área urbana.

É o meio urbano e o seu entorno que abriga grande parte de população, centraliza fatores econômicos e sociais do município, além de infraestruturas cabíveis para o atendimento ao turista, como posto de combustível, agências bancárias, bares e restaurantes, lojas, meios de hospedagens, dentre outros. Tal congregação serve como um suporte acolhedor para os visitantes e não impede, até mesmo auxilia, que o turismo se expanda para as áreas mais afastadas. Para tanto, é necessário planejar e adequar o perfil dos meios naturais, com os olhos voltados para que o meio ambiente sofra o menor impacto possível, uma vez que o município é envolvido por diversas áreas "patrimonializadas".

Neste contexto, a cartografia de síntese exibindo tipos de paisagem pode contribuir para diversas pesquisas direcionadas para o planejamento. Martinelli (2001b) afirma que os

\footnotetext{
${ }^{44} \mathrm{O}$ gradiente é determinado por meio de um cálculo matemático que permite detectar, no perfil longitudinal de um rio, alterações no seu curso, uma vez que relaciona a declividade do canal com a extensão do respectivo trecho, fornecendo assim, um índice para comparação de trechos fluviais de diferentes magnitudes.

${ }^{45}$ Prática de remar um caiaque inflável.
} 
conjuntos espaciais que se constituem como tipos de paisagem, quando direcionadas para o turismo poderão ser vistos como tipos de paisagem dotados de potencial turístico. Como resultado da integração de diferentes fatores ou elementos dos meios físicos e sociais, o mapa síntese de São Luiz do Paraitinga torna-se um relevante meio de comunicação no processo de gestão do turismo para o município.

\subsection{Proposta preliminar para um zoneamento turístico do município}

Muito embora o mapa de síntese apresentado possa ser de acessível entendimento ao usuário para ter uma visão de conjunto e integrada do município, o mesmo poderá servir de insumo para um bom planejamento, vislumbrando um turismo consumptivo mais atento. Diante das possibilidades expostas para os desdobramentos das atividades turísticas em São Luiz do Paraitinga, sistematizou-se a pesquisa, nesta etapa, por meio de uma nova representação cartográfica decorrente da síntese, no intuito de deixar à reflexão uma proposta preliminar de zoneamento turístico.

A partir do mapa dos tipos de paisagem, cientes das particularidades, dos amplos potenciais e dos possíveis riscos, ou seja, perante a realidade e os conhecimentos prévios da autora, executou-se a base a qual orientou a elaboração de um mapa proposto. Concebeu-se, desse modo, para cada unidade espacial uma sugestão de relevar a faculdade do turismo e suas fruições, conforme a reprodução descritiva adiante:

ÁREA 1 - Grande parte desta área é de especial interesse de preservação ambiental, inserida dentro dos limites da Zona de Amortecimento da Unidade de Conservação da Serra do Mar, fato que proporciona atividades de contato com a natureza. Na porção norte, há trilhas e presença de médias cachoeiras propícias ao banho. Na parte sul, devido ao relevo íngreme, a mata densa e pouco explorada, há trilhas indicadas para aventureiros. Nesta área localiza-se o pico do Alto do Pinga, que propicia uma fascinante vista panorâmica para os altos da Serra do Mar e parte do litoral. Salienta-se, também, a presença da Cachoeira Vitória, divida em três partes, que, somadas, chegam a 50 metros, sendo possível praticar arborismo, em meio a grandes araucárias e quaresmeiras, além de possuir um enorme "paredão" rochoso, ideal para a prática de cascading e rapel. 
ÁREA 2 - Área com relevo montanhoso e presença significativa de plantações de eucalipto na porção norte, com pouco potencial para a fruição de atividades turísticas. $\mathrm{Na}$ parte sul o turismo ainda é pouco aproveitado, porém, existem diversas antigas e modestas propriedades rurais, rodeadas de caminhos ao meio de campos naturais, proveitosas para curtas caminhadas e passeios a cavalo. É possível, outrossim, relacionar-se com a cultura caipira e, as estradas de terra, com médios declives, fomentam jornadas de off-road. Não obstante, esta região ainda requer vários incentivos para o desenvolvimento da prática do turismo.

ÁREA 3 - Unidade de preservação protegida e patrimônio natural que corresponde ao Parque Estadual da Serra do Mar, sob gestão do Núcleo Santa Virgínia. Apesar de possuir duas pousadas bastante simples, é mais elevado o número de visitantes devido a acentuada influência da Mata Atlântica, com destaque para os rios com fortes corredeiras e a presença de cachoeiras nos seus afluentes. Área propícia para turismo de aventura, como cascading, trilhas com níveis médios em meio da mata fechada e prática de rafting no rio Paraibuna. Nesta área também há a Reserva Guainumbi, adquirida em 2005 por um biólogo, com o propósito de contribuir com a educação ambiental, por intermédio de cursos e treinamentos, em especial, o exercício de observar as diversas espécies de aves.

ÁREA 4 - Área com destaque para o vale do rio do Chapéu, com presença de algumas médias cachoeiras e amplos campos naturais, propícios para a prática de cavalgaria. Nesta área, existem cinco meios de hospedagem, com maior concentração no extremo leste, no bairro de Catuçaba, de fácil acessibilidade através da única estrada asfaltada municipal existente. Esta também possibilita a afluência para a via de terra, conhecida como antigo caminho para a cidade de Ubatuba, o que oportunizou a permanência de clássicas fazendas e sedes com belas edificações arquitetônicas, construídas nos séculos passados pelos barões do café. Embora tais fazendas ainda sejam pouco exploradas, destacam-se como potencialidades para o turismo rural, em especial, àquele voltado para os acontecimentos históricos.

ÁREA 5 - Predomínio de colinas suaves, pequenas propriedades rurais, famílias tradicionais com costume caipira, que atuam nas lavouras de milho e leguminosas caracterizam essa área. Na porção norte, encontram-se sítios cujos moradores impulsionam o artesanato local, como móveis rústicos e diversos produtos de madeira. Área com grande potencial para o turismo rural, porém, ainda pouco explorada e com presença apenas de duas 
modestas pousadas que oferecem a tranquilidade do meio natural. Nesta região, há a prática de esportes de leves montanhas, como mountain bike e caminhadas. Estes atos são facilitados, devido, principalmente, as estradas de terra e caminhos feitos pelo gado.

ÁREA 6 - Espaço onde os acessos pelas estradas estaduais asfaltadas em boas condições, e a proximidade com o recinto urbano, beneficiam a concentração de meios de hospedagem, totalizando oito equipamentos instalados. É uma área parcialmente inserida no vale do rio Paraitinga, com moderadas corredeiras e pequenas quedas d'águas, recursos naturais propícios para a prática de ducking e "bóia-cross". O relevo suave da região também favorece atividades turísticas, como as leves trilhas nos fragmentos de mata nativa. $\mathrm{O}$ destaque deve ser dado para o circuito de turismo do Bairro Mato Dentro, um atrativo onde o turista pode desbravar o caminho rural que o leva até à cidade, contemplar belas paisagens, visitar a fazenda histórica São Luiz e degustar os produtos artesanalmente fabricados pela tradicional cachaçaria Mato Dentro.

ÁREA 7 - Área urbana, espaço no qual está localizada a sede do município e caracterizada pela concentração populacional. Presença de edificações arquitetônicas históricas, festas tradicionais, gastronomia e costumes declarados patrimônio cultural, além de equipamentos e infraestruturas de apoio ao turismo, como bares e restaurantes, rodoviária, bancos, lojas, meios de hospedagem (dez pousadas e dois campings), entre outros. Um passeio pelo centro histórico leva o visitante a percorrer os principais atrativos turísticos, como a casa Dr. Oswaldo Cruz, as igrejas Matriz (em recuperação) e do Rosário, a capela das Mercês, o Mercado Municipal e demais lugares rodeados pelos coloridos e históricos casarios tombados. Encontra-se, nesta área, a Praça Oswaldo Cruz, ponto de encontro e manifestação de diversos eventos culturais, sobretudo o famoso carnaval de marchinhas e a festa do Divino.

Diante de tais colocações, apresenta-se, a seguir, um mapa prévio e sugestivo de zoneamento turístico (figura 42), constituído por uma legenda a qual exibe as principais alternativas direcionadas a prática do turismo no município. Permitiu, outrossim, acrescentar na legenda as imagens fotográficas com o intento de aproximar a veracidade do turismo local com o usuário do mapa. 
SÃO LUIZ DO PARAITINGA (SP): PROPOSTA PRELIMINAR DE ZONEAMENTO TURÍSTICO, 2013
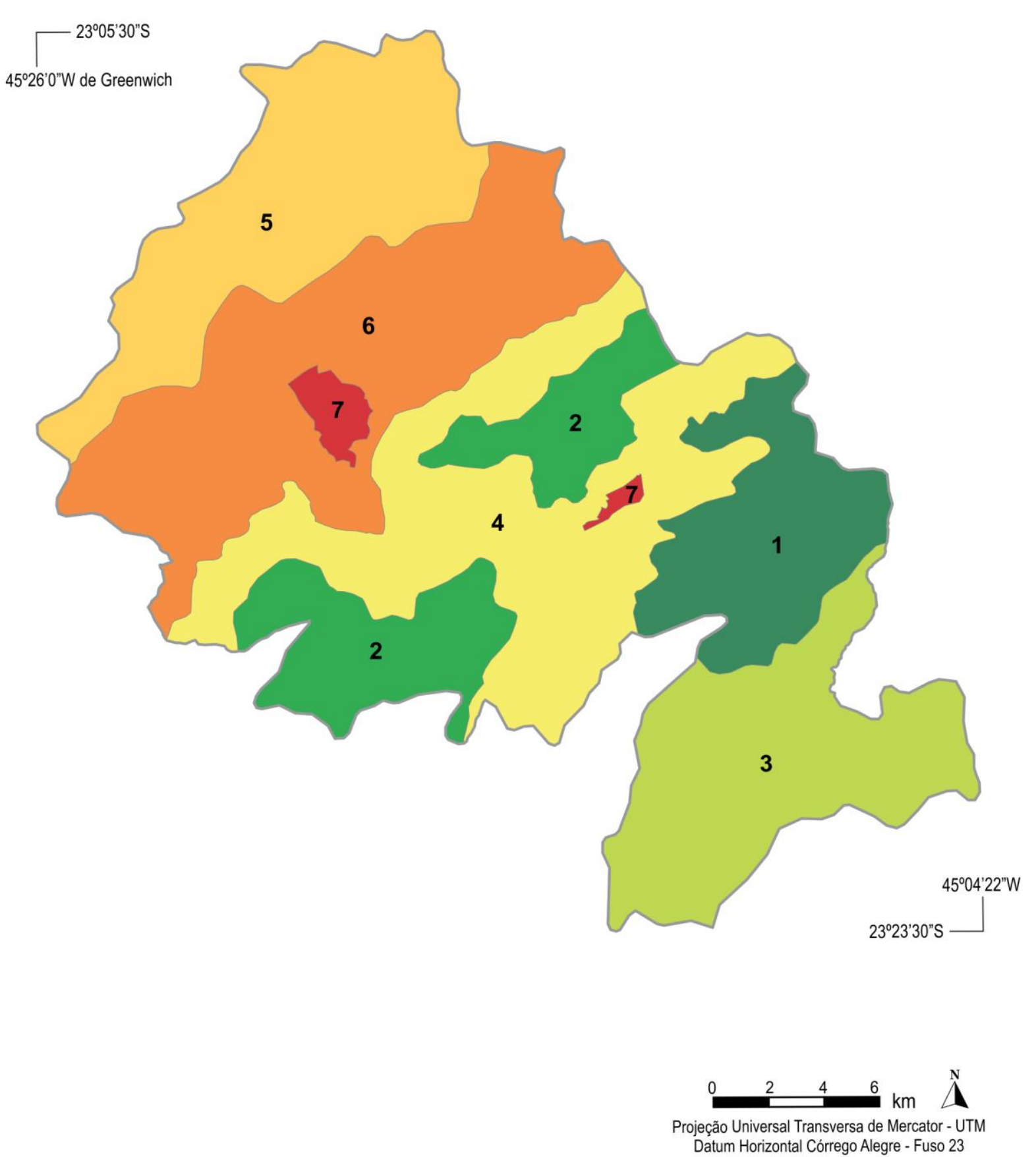

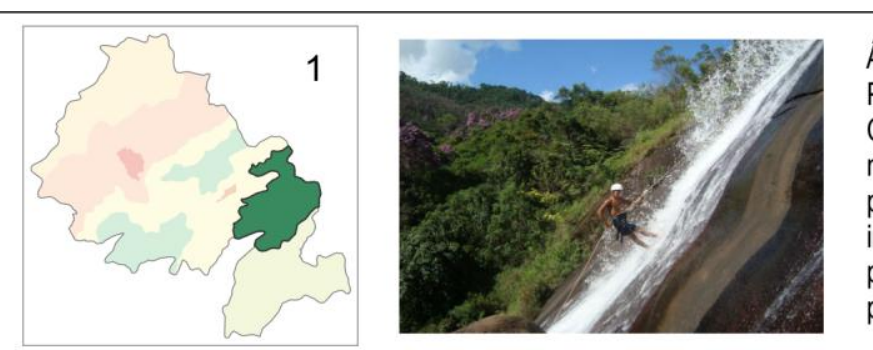

Parte desta área está inserida dentro da Zona de Amortecimento da Unidade de Conservaça da Serra do Mar, fato que proporciona atividades de contato com a parte sul, devido ao relevo ingreme, mata densa e pouco explorada há trilhas indicadas para aventureiros. Nesta área localiza-se o pico do Alto do Pinga, que propicia uma vista panorâmica para a Serra do Mar e parte do litoral. Destaque para a Cachoeira Vitória, favorável para a prática de arborismo, cascading e rapel. ÁREA2

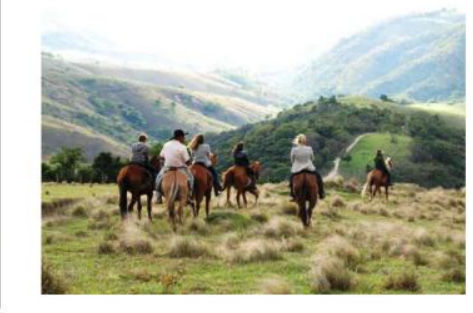

Relevo montanhoso e presença significativa de plantaçōes de eucalipto na porção norte, com pouco polectial para a fliçao de allidades turlicas. Na parte sul, 0 rurais, rodeadas de caminhos an meio de campos ideais para curtas caminhadas passeios a cavalo. As estradas de terra com médios declives fomentam jornadas de off-road. Esta regiäo ainda requer vários incentivos para o desenvolvimento da
prática do turismo.

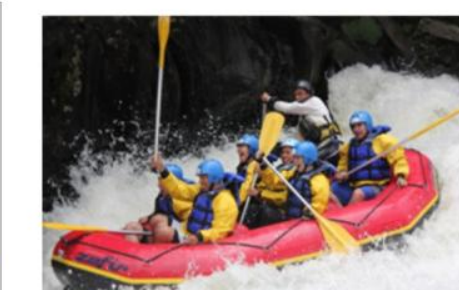

AREA 3

Patrimonnio natural que corresponde ao Parque Estadual de Serra do Mar, sob gestão do Núcleo Santa Virginia. Possui apenas duas pousadas, mas o numero de visitantes cachoeiras. Área propicia pro o turismo de aventura como casceding trithas en meio da mata fechada e prática de rafting no rio Paraibuna. Nesta área também há a Reserva Guainumbi que contribui para a educação ambiental, além do exercicio de observar as espécies de aves.

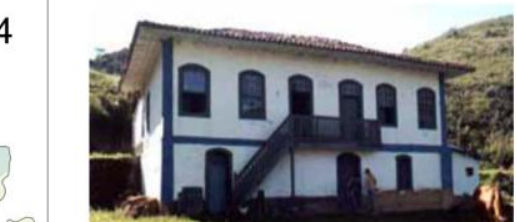

ÁREA4

Destaque para o vale do rio do Chapéu, com presenç̧a de algumas cachoeiras e campos naturais propicios para a pratica de calvagaria. Existem cinco meios $d$ tácil acesso pela estrada municial asfaltada. Presença de clássicas fazendas e sedes com edificaçōes arquitetônicas construídas nos séculos passados. Tais fazendas ainda são pouco exploradas, porém, mostram-se como potencialidades

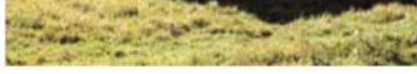

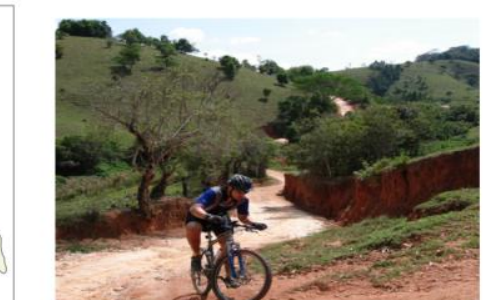

ÁREA 5

Colinas suaves, pequenas propriedades ruris, familias tradicionais com costume caipira. Na porçăo notre há produçăa de artesanato, como móveis rústicos $\mathrm{e}$ produtos ee madeira. Area com potecial para o turismo rural, porém, ainda pouco explorada $e$ Nesta região, há a práticas de esportes de leves montanhass como mountain bike caminhadas, favorecidos, principalmente, pelas estradas de terra e caminhos feitos pelo gado.

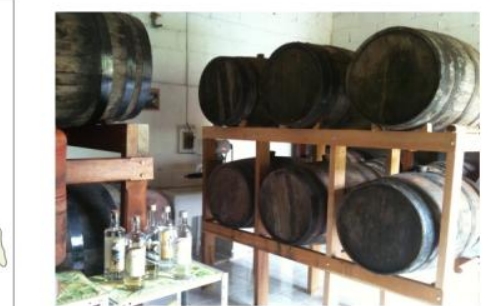

AREA 6

Concentraçăo de oito meios de hospedagem beneficiados pelas estradas asfaltadas e proximidade com o recinto urbano. Area parcialmente inserida no vale do rio propicios par a prática de ducking "bói-cross' e leves trilhas nos nichos de Destaque para o circuito do Bairro Mato Dentro, onde o turista pode desbravar o caminho rural que o leva ate a cidade, comtemplar belas paisagens, visitar a fazenda histórica São Luiz e degustar os produtos artesanais da cachaçaria Mato Dentro.

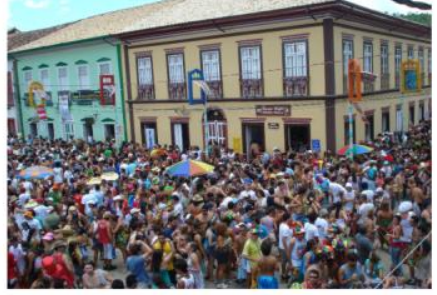

AREA 7

Espaço urbano caracterizado pela concentraçăo populacional, festas tradicionais, edificaçōes arquitetotônicas históricas, gastronomia e costumes declarados pattimônio dez pousadas e dois campings. Os principais atrativos turisticos são a casa do Oswaldo Cruz, as igrejas Matrize do Rosário, a capela das Mercếs, o Mercado Municipal e demais lugares rodeados pelos casarios tombados. Destaque para a Praça Oswaldo 


\section{CONSIDERAÇÕES FINAIS}

Releva-se, diante deste trabalho, a possibilidade de abordar a integridade de importantes aspectos da ciência geográfica, ciência cartográfica e os estudos do turismo. Esta agregação facultou o manejo de recurso teórico-metodológico que forneceu conhecimentos auxiliares para se alcançar o propósito estabelecido na presente pesquisa.

Alguns obstáculos desafiaram a argúcia da autora, como, por exemplo, a coleta de dados estatísticos e espaciais referentes ao objeto de estudo. Poucos documentos são oficialmente registrados no município de São Luiz do Paraitinga, com exceção aos estudos voltados para área urbana e projetos elaborados a partir do conhecimento do patrimônio cultural arquitetônico.

O município, por estar situado em uma área de ligação entre as cidades de Taubaté e Ubatuba, ainda se enquadra no perfil de turismo receptivo de "curta temporada". A maioria dos turistas permanece no lugar apenas um dia ou um final de semana, mesmo durante as épocas festivas, e visitam apenas o centro histórico. Dessa forma, embora o município possua grande potencial para o turismo rural e de natureza, os mesmos encontram, até então, pouca receptividade.

Recentemente, ao término desta pesquisa, obteve-se a informação, junto a diretoria de turismo, que um novo projeto de implantação de corredores, rotas e caminhos turísticos, nas regiões passíveis de atrativos naturais será implantado. Costuma-se dizer que São Luiz do Paraitinga é uma pequena cidade inserida num grande município, cuja maioria dos eventos acontece na área urbana e o meio rural, muitas vezes, é excluído desse contexto. Desta perspectiva, incluindo a contribuição do uso preliminar das informações ancoradas nesta dissertação, o recente projeto municipal procura democratizar o turismo, distribuir e demarcar pelo território os mais diversos atrativos, desde uma simples cachoeira a uma comunidade caipira, passando por mirantes, trilhas, capelas rurais, vendas de roça, fazendas históricas, propriedades privadas e Parque Estadual da Serra do Mar.

O projeto considera que um planejamento bem estruturado possa contribuir para a diminuição do êxodo rural e a fixação do homem do campo. Ademais, através das visitações nas propriedades rurais, haverá uma maior geração de renda nessas localidades, fato este que acelerará o desenvolvimento econômico de todo o município. Acredita-se que a execução desse plano proporcionará, como corolário, melhorias nas estradas, favorecendo o escoamento 
da produção rural e o transporte escolar, elevando a autoestima e assegurando maior conforto do homem do campo.

Dentro desta e outras particularidades do território luziense, buscou-se, neste estudo, fundamentos necessários para a compreensão do dinamismo do turismo, do ponto de vista da geografia e da cartografia. Isto viabilizou a construção de representações gráficas, capazes de permitir a realização de uma leitura crítica dos concretos acontecimentos no município.

Entende-se que a cartografia emerge entre diferentes abordagens da realidade, sensíveis à natureza e à sociedade. Deste modo, perseguiu-se uma cartografia do turismo, com amplo alcance de entendimento, apesar desta, ainda, não ter atingido sua sistematização científica e ser vista como um ramo especializado da cartografia temática.

A cartografia temática, com base na semiologia, assumiu uma conotação relevante, uma vez que, mediante o inventário, tem a capacidade de ordenar, classificar, dividir ou integrar fenômenos e objetos turísticos num dado espaço por meio de uma linguagem gráfica e visual.

Os estudos pautados na abordagem da cartografia temática, com a utilização de sucessivos mapas, foram capazes de demonstrar uma realidade integrada e a compreensão da prática do turismo em São Luiz do Paraitinga. Este entendimento contribuiu para a percepção das atividades turísticas e ensejou sua aplicação no meio físico e social, em suas diversas expressões.

Discorreu-se sobre múltiplas singularidades e atributos necessários para elaboração de diversos mapas analíticos e, posteriormente, por intermédio do agrupamento daqueles, tornouse viável a elaboração de um mapa síntese, delimitado e identificado pelos tipos de paisagens. A cartografia de síntese permitiu a congregação homogênea, dentro de uma concepção holística, dos elementos naturais e sociais, componentes indispensáveis no desenvolvimento do turismo. Neste contexto, a cartografia de síntese serviu como um apoio para o planejamento na medida em que busca expressar a complexidade existente da paisagem e garantiu um nível de detalhamento equilibrado entre as particularidades adotadas.

Este construto foi fundamental para o avanço de um ensaio cartográfico que embasou o produto final desta pesquisa. O cerne do raciocínio foi a preocupação com a falta de planejamento voltado para do turismo de São Luiz do Paraitinga. Não por outra razão, trabalhou-se, a partir do mapa síntese por tipos de paisagem, a elaboração de outro mapa que entreveria a possibilidade de se propor, mesmo que de forma preliminar, um zoneamento turístico para o município. 
Salienta-se, também, o papel primordial que as novas tecnologias (geoprocessamento e/ou internet) exercem na efetivação da análise da paisagem. A amplitude de possibilidades de cruzamento de dados e informações confere e facilita ao pesquisador um amplo entendimento da realidade representada. A utilização de SIG no planejamento transversal da paisagem e a integração com o turismo é evidente.

Em face do resultado atingido neste trabalho, acredita-se que a cartografia temática analítica e de síntese possa contribuir na leitura e visualização das potencialidades turísticas em busca do planejamento, desenvolvimento e fruição do turismo de maneira consciente. Há de preocupar-se, igualmente, com os usos do patrimônio cultural urbano, dos espaços rurais e das áreas naturais do município de São Luiz do Paratitinga. À luz de tais considerações, crêse, que este construto seja suscetível de constituir adminículos para outras pesquisas, bem como para outros lugares turísticos. 


\section{REFERÊNCIAS BIBLIOGRÁFICAS}

AB'SABER, Aziz Nacib. São Luiz do Paraitinga, espaços rurais. Revista Scientific American Brasil. São Paulo, nº 67, novembro de 2007.

ALMEIDA, Regina Araújo; GUERRERO, Ana Lúcia; FIORI, Sérgio. Caminhos do Futuro, Geografia e Cartografia para o Turismo. Ministério do Turismo - AVT/IAP - NT/USP, São Paulo: IPSIS, 2007.

BARRETO, Margarida. Planejamento e organização do turismo. Campinas: Papirus, 2003.

BARBOSA, Ycarim. O despertar do turismo: uma visão crítica dos não lugares. São Paulo: Aleph, 2001.

BERTIN, Jacques. La sémiologie graphique. Paris-La Haye: Moutonn-Gauthier-Villars, 1973.

Flammarion, 1977.

La Graphique et le Traitement Graphique de l'Information. Paris:

BRASIL. Constituição da República dos Estados Unidos do Brasil (1934). Diário Oficial da União. Brasília, julho de 1934.

Constituição da República Federativa do Brasil (1988). Diário Oficial da União. Brasília, outubro 1988.

CÂMARA, Gilberto. Anatomia de Sistemas de Informação Geográfica: visão atual e perspectivas futuras. II Simpósio Brasileiro de Geoprocessamento. Anais. São Paulo: EPUSP, 1993. p. 157-183.

CARLOS, Ana Fani Alessandri. O consumo do espaço. In: (org). Novos caminhos da Geografia. São Paulo: Contexto, 1999. p. 173-186.

CASTRO, Iná Elias. Paisagem e turismo. De estética, nostalgia e política. In: YÁZIGI, Eduardo (org). Turismo e Paisagem. São Paulo: Contexto, 2002. p. 121-140.

CBH-PS, Comitê das Bacias Hidrográficas do rio Paraíba do Sul. Plano da Bacia Hidrográfica do Paraíba do Sul (UGRHI-02) 2009-2011. Fundação Christiano Rosa, Piquete, 2009.

CHOAY, Françoise. A Alegoria do Patrimônio. São Paulo: Unesp, 2000.

CIFELLI, Gabrielle. A refuncionalização turística do patrimônio cultural: os novos usos do território apropriado pelo turismo em Ouro Preto - MG. In: PAES, Maria Tereza; 
OLIVEIRA, Melissa (Orgs). Geografia, Turismo e Patrimônio Cultural. São Paulo: Annablume, 2010. p. 113-136.

CONDEPHAAT, Conselho de Defesa do Patrimônio Histórico Arqueológico, Artístico e Turístico. Secretaria da Cultura do Estado de São Paulo. São Luis do Paraitinga: Revitalização do Centro Histórico, São Paulo, 1982.

CONTI, José Bueno. Ecoturismo, Paisagem e Geografia. In: RODRIGUES, Adyr Balastreti (org). Ecoturismo no Brasil: possibilidades e limites. São Paulo: Contexto, 2003. p. 59-69.

CORREA, Felipe. O Renascimento de São Luiz do Paraitinga. Projeto Experimental. Graduação em Comunicação Social, Universidade de Taubaté, Taubaté, 2010.

CRUZ, Rita de Cássia. As paisagens artificiais criadas pelo turismo. In: YÁZIGI, Eduardo (org). Turismo e Paisagem. São Paulo: Contexto, 2002. p.107-119.

Introdução à Geografia do Turismo. $2^{\circ}$ ed. São Paulo: Rocca, 2003.

. Políticas públicas de turismo no Brasil: território usado, território negligenciado.

In: Revista Geosul, v. 20, n 40, Florianópolis, 2005. p. 27-43.

Planejamento governamental do turismo: convergências e contradições na produção do espaço. In: América Latina: cidade, campo e turismo. LEMOS, Amalia Inés; ARROYO, Mónica; SILVEIRA, María Laura (orgs). Consejo Latinoamericano de Ciencias Sociales - CLACSO, San Pablo, 2006. p. 337-350.

D.O.E., Diário Oficial do Estado. Secretaria da Cultura do Estado de São Paulo. Resolução 55, de 13.05.1982, Seç. I, São Paulo, 28 de maio de 1982.

DUQUE, Renato Câmara; MENDES, Catariana Lutero. O Planejamento Turístico e a Cartografia, São Paulo: Alínea, 2006.

FIORI, Sérgio Ricardo. Cartografia e as Dimensões do Lazer e Turismo: o Potencial dos Tipos de Representação Cartográfica. Revista Brasileira de Cartografia. nº62/03. São Paulo, 2010. p. 527-542.

HALL, Colin Michael. Planejamento turístico: políticas, processos e relacionamentos. São Paulo: Contexto, 2001.

HARlEY, J. B. A Nova História da Cartografia. O Correio da Unesco. UNESCO, ano 19, n'. 8. São Paulo, 1991.

HENRIQUES, Eduardo Brito. A Lisboa turística, entre o imaginário e a cidade: A construção de um lugar turístico urbano. Lisboa: Edições Colibri, 1996. 
IBGE, Instituto Brasileiro de Geografia e Estatística. Censos Demográficos. Disponível em: <http://www.censo.ibge.gov.br/>. Acesso em 29 de fevereiro de 2012.

. CIDADES@. Disponível: <http://www.cidades.ibge.gov.br/xtras/home.php>

Acesso em 29 de fevereiro de 2012.

IF, Instituto Florestal do Estado de São Paulo. Inventário Florestal 2008. Disponível em: <http://www.iflorestal.sp.gov.br/sifesp/inventario.html>. Acesso em: 25 de abril de 2013.

IPHAN, Instituto do Patrimônio Histórico e Artístico Nacional. Dossiê de Tombamento São Luiz do Paraitinga/SP: um programa da "ilustração". Proposta de tombamento da cidade configurada a partir do plano raçado no século XVIII. São Paulo, 2010.

Patrimônio Cultural. Disponível em:

$<$ http://portal.iphan.gov.br/portal/montarPaginaSecao.do?id=20\&sigla=PatrimonioCultural\&r etorno=paginaIphan>. Acesso em 12 de dezembro de 2012.

Tombamento. Disponível em:

<http://portal.iphan.gov.br/portal/montarPaginaSecao.do?id=12576\&retorno=paginaIphan>. Acesso em 12 de dezembro de 2012.

JOLY, Ferdnand. A Cartografia. $8^{\circ}$ ed. Campinas: Papirus, 1990.

JORNAL DA RECONSTRUÇÃO. Como Tudo Aconteceu. São Luiz do Paraitinga, Ano I, $\mathrm{n}^{\circ}$ 1. Março de 2010.

Eis o Novo Patrimônio Cultural. São Luiz do Paraitinga, Ano I, $\mathrm{n}^{\circ} 13$. Dezembro de 2010.

LACOSTE, Ives. A Geografia Isso Serve, em Primeiro Lugar para Fazer a Guerra, $12^{\circ}$ ed. São Paulo: Papirus, 2006.

LIBAULT, André. Geocartografia. São Paulo: Ed. Nacional, 1975.

LOCH, Ruth E. Nogueira. Cartografia: representação, comunicação e visualização de dados espaciais. Florianópolis, Ed. UFSC, 2006.

MARTINELLI, Marcello. Os fundamentos semiológicos da cartografia Temática. In: XV Congresso Brasileiro de Cartografia. Anais. São Paulo, SBC/USP, 1991, p. 419-422.

Cartografia ambiental: uma cartografia diferente? Revista do Departamento de

Geografia. Universidade de São Paulo, São Paulo, v. 7, p. 61-80, 1994. 
Cartografia do turismo: que cartografia é essa? In: LEMOS, Amália Inês G. de (org). Turismo: Impactos Socioambientais. $3^{\circ}$ ed. São Paulo: Hucitec, 2001a. p. 296-302.

. Cartografia do turismo e imaginário. In RODRIGUES, Adyr B. (org). Turismo rural. São Paulo: Contexto, 2001b. p. 151-170

Os passos da sistematização da cartografia temática. In: II Simpósio Internacional Caminhos Atuais da Cartografia. Anais. São Paulo, FFLCH-DG-USP, 2010, p. 965-990.

. Mapas da geografia e cartografia temática. 6ª ed. São Paulo: Contexto, 2011.

MARTINELLI, Marcello; Pedrotti, Franco. A Cartografia das unidades de paisagem: questões metodológicas. Revista do Departamento de Geografia. nº 14. USP, São Paulo, 2001, p. 3946.

MARTINELLI, Marcello. RIBEIRO, Mônica. Cartografia para o turismo: símbolo ou linguagem gráfica. In: RODRIGUES, Adyr Balasterti. (org.) Turismo e Desenvolvimento Local. $3^{\circ}$ ed. São Paulo, 2002. p. 190-199

MELLO, Tatiana. Estrutura da vegetação, cobertura florestal e preferências de uso da paisagem associadas a vertentes: as quase-florestas de São Luiz do Paraitinga (SP). Dissertação de mestrado - Instituto de Biociências, Universidade de São Paulo, 2009.

MOARES, Antônio Carlos. Geografia: pequena história crítica. $19^{\circ}$ ed. São Paulo: Hucitec, 2003.

MOURA, Ana Clara; RIBEIRO, Rosemary. Cartografia destinada ao turismo autoguiado. In: V Congresso e Feira para Usuários de Geoprocessamento na América Latina. Anais. GisBrasil99. Salvador, 1999.

MOURA, Ana Clara; OLIVEIRA, Sérgio; LEÃO, Cláudio. Cartografia e geoprocessamento aplicados os estudos em turismo. Geomática, Santa Maria, v. 1, 2006. p. 77-87.

MTE, Ministério do Trabalho e Emprego. Relação Anual de Informações Sociais - RAIS. Disponível em: <http://portal.mte.gov.br/rais/>. Acesso: 05 de maio de 2012.

MTur, Ministério do Turismo Anuário Estatístico de Turismo 2012. Ano Base 2011, vol. 39. Disponível: 〈www.dadosefatos.turismo.gov.br/dadosefatos/anuario>. Acesso em 01 de novembro de 2012.

MÚJICA, Josefina. Cartography in the Tourist Promotion of the Canary Island (1880-1970).

Boletin de la A.G.E., nº44, University of Las Palmas de Gran Canaria, 2007. p. 387-390. 
NODARI, Luciana; BECKER, T; CANALE, D. A aplicação do geoprocessamento como ferramenta de auxílio ao turismo. In: Congresso de cadastro técnico multifinalitário e gestão territorial. Anais. nº 7, UFSC, Florianópolis, 2006.

OLIVEIRA, Ivanilto José. Cartografia Aplicada ao Planejamento do Turismo. Boletim Goiano de Geografia. Goiana, v.20, 2005. p. 29-46.

Cartografia Turística para Fruição do Patrimônio Natural da Chapada dos Veadeiros (GO). Tese (Doutorado em Geografia). Faculdade de Filosofia, Letras e Ciências Humanas, Universidade de São Paulo, São Paulo, 2007.

OMT, Organização Mundial do Turismo. Introdução ao Turismo. São Paulo: Roca, 2001.

PAES-LUCHIARI, Maria Tereza Duarte. A reinvenção do patrimônio arquitetônico no consumo das cidades. Revista GEOUSP: Espaço e Tempo. nº17, São Paulo, 2005. p. 95-105.

PAES, Maria Tereza Duarte; OLIVEIRA, Melissa Ramos da Silva (org). Geografia, Turismo e Patrimônio Cultural. São Paulo: Annablume, 2010.

. São Luiz do Paraitinga (São Paulo - Brasil) - O Patrimônio Cultural Brasileiro em Reconstrução. In: IGLESIAS, Maria Carolina Casals; Instituto del Patrimonio Turístico (org). Patrimonio Turístico en Iberoamérica: experiencias de investigación, desarollo y innovación. Santiago (Chile), 2012. p.19-32.

PEREIRA, Danilo. O patrimônio ambiental urbano de São Luiz do Paraitinga e políticas públicas de preservação. Trabalho de Graduação Individual em Geografia. Faculdade de Filosofia, Letras e Ciências Humanas, Universidade de São Paulo, São Paulo, 2012.

PETERSON, Michael. The internet and multimedia cartography. In: CARTWRIGHT, William; PETERSON, Michael; GARTNER, George (org.). Multimedia Cartography. $2^{\circ}$ ed., Berlin: Springer-Verlag, 1999, p. 35-50.

PETROCCHI, Mário. Turismo: Planejamento e gestão. $6^{\circ}$ ed. São Paulo: Futura, 2002.

PETRONE, Pasquale. A região de São Luiz do Paraitinga. Revista Brasileira de Geografia. v. 1, no 3, 1959, p. 3-99.

PESQUISA revela que São Luiz do Paraitinga está 'pronta' após trágica enchente. Vnews, 25 de junho de 2010. Disponível em: <http://www.vnews.com.br/noticia.php?id=74545>. Acesso em 26 fevereiro de 2012.

PREFEITURA Municipal de São Luiz do Paraitinga (SP). Disponível em: <http://www.saoluizdoparaitinga.sp.gov.br/site/>. Acesso em: abril de 2010 a agosto de 2013. 
RAMOS, Cristhiane da Silva. Visualização cartográfica e cartografia multimídia: conceitos e tecnologia. São Paulo: UNESP, 2005.

RIZZI, Patrícia. Visualização cartográfica aplicada ao turismo: uma proposta metodológica. In: XXI Congresso de Cartografia. Anais. Belo Horizonte, 2003.

ROBINSON, Arthur Howard. et al. Elements of cartography. $6^{\circ}$ ed. New York: John Wiley \& Sons, Inc, 1995.

RODRIGUES, Adyr Balasterti. Turismo e espaço: rumo a um conhecimento transdisciplinar. São Paulo: Hucitec, 1997.

Desafios para os estudiosos em Turismo. In: (org). Turismo e

Geografia: reflexões teóricas e enfoques regionais. $2^{\circ}$ ed. São Paulo: Hucitec, 1999.

RODRIGUES, Marly. Preservar e consumir: o patrimônio histórico e o turismo. In: FUNARI, Pedro; PINSKY, Jaime. Turismo e Patrimônio Cultural. São Paulo: Contexto, 2011.

ROSA, Roberto; BRITO, Jorge Luis Silva. Introdução ao Geoprocessamento: Sistema de Informações Geográficas. Uberlândia: EDUFU, 1996.

SANTOS, Carlos Murilo Prado. O reencantamento das cidades: tempo e espaço na memória do patrimônio cultural de São Luiz do Paraitinga/SP. Dissertação (Mestrado em Geografia), Instituto de Geociência, Universidade Estadual de Campinas, Campinas, 2006.

SANTOS, L. A.; DIAS, N.W.; TARGA, M.S. Geoprocessamento aplicado à análise do balanço hídrico e na determinação das chuvas necessárias para a inundação da represa na bacia do Ribeirão Itaim, Taubaté, SP. In: II Seminário de Recursos Hídricos da Bacia Hidrográfica do Paraíba do Sul: Recuperação de Áreas Degradadas, Serviços Ambientais e Sustentabilidade, Anais, Taubaté, 2009, p.647-654.

SANTOS, Milton. Por uma outra globalização: do pensamento único à consciência universal. $6^{\circ} \mathrm{ed}$. Rio de Janeiro: Record, 2001.

. Metamorfoses do Espaço Habitado: Fundamentos teóricos e metodológicos da geografia. $6^{\circ}$ ed. São Paulo: Edusp, 2008a.

Edusp, 2008b.

A Natureza do Espaço: Técnica e Tempo. Razão e Emoção. $4^{\circ}$ ed. São Paulo:

SÃO PAULO (Estado). Secretaria do Meio Ambiente (SMA). Plano de manejo do Parque Estadual da Serra do Mar. São Paulo, 2006. 
Secretaria de Agricultura e Abastecimento. Coordenadoria de Assistência Técnica Integral. Instituto de Economia Agrícola. Levantamento censitário de unidades de produção agrícola do Estado de São Paulo - LUPA 2007/2008. São Paulo: SAA/CATI/IEA, 2008. Disponível em: <http://www.cati.sp.gov.br/projetolupa〉. Acesso em 25 de julho de 2013.

SAUER, Carl. A morfologia da paisagem. In: CORRÊA, Roberto Lobato; ROSENDAHL, Zeny (orgs). Paisagem, tempo e cultura. Rio de Janeiro: EdUERJ, 1998, p. 12-74.

SCALCO, Raquel Faria. A cartografia multimídia e a informação turística: uma análise de diferentes maneiras de disponibilizar a informação turística baseada nos recursos do geoprocessamento. Caderno Virtual de Turismo, v. 6, Rio de Janeiro, 2006. p. 43-53.

SCIFONI, Simone A construção do patrimônio natural. Tese (Doutorado em Geografia), Faculdade de Filosofia, Letras e Ciências Humanas, Universidade de São Paulo, São Paulo, 2006.

SALICHTCHEV, Kontastin. Cartographic communication: its place in the theory science. The Canadian Cartographer, v.15, no 2, Toronto, 1978. p. 93-100.

. A. Algumas reflexões sobre o objeto e o método da Cartografia depois da Sexta Conferência Cartográfica Internacional (1977) - Tradução de Regina Vasconcellos. In: Seleção de Textos: Cartografia Temática, nº 18, AGB, São Paulo, 1988, p. 17-24.

SEADE, Fundação Sistema Estadual de Análise de Dados. Secretaria Estadual de Economia e Planejamento (SP). Índice Paulista de Responsabilidade Social (IPRS), 2010. Disponível: www.iprsipvs.seade.gov.br/view/index.php?selLoc $=0 \&$ selTpLoc $=2 \&$ prodCod=1. Acesso em: 22 de dezembro de 2012.

SIRGADO, José Rafael. Espaço turístico e desenvolvimento no Cone Leste Paulista. In: RODRIGUES, Adyr Balasteri (Org.) Turismo rural: prática e perspectiva. São Paulo: Contexto, 2003.

SILVA, Marinyl. A Cartografia Temática no estudo do turismo: o município de Santo Antônio do Pinhal. Dissertação (Mestrado em Geografia), Faculdade de Filosofia, Letras e Ciências Humanas, Universidade de São Paulo, São Paulo, 2010.

TAYLOR, David. The concept of cybercartography. In: Peterson, Michael (org). Maps and the internet. Cambridge: Elsevier, 2005.

VEIGA, Teresa Cristina; XAVIER DA SILVA, Jorge. Geoprocessamento aplicado à identificação de áreas potenciais para atividades turísticas: o caso do município de Macaé-RJ. In: XAVIER DA SILVA, Jorge; ZAIDAN, Ricardo Tavares (Org.). Geoprocessamento e análise ambiental: aplicações. Rio de Janeiro: Bertrand Brasil, 2004. 
VIAMICHELIN. The Michelin Guide: 100 editions and over a century of history. Disponível: 〈http://www.viamichelin.co.uk/tpl/mag6/art200903/htm/tour-saga-michelin.htm> Acesso em 04 de setembro de 2013.

XAVIER DA SILVA, Jorge. Geoprocessamento para análise ambiental. Rio de Janeiro: Ed. do autor, 2001.

YÁZIGI, Eduardo (org). Turismo e Paisagem. São Paulo: Contexto, 2002.

. Civilização urbana: planejamento e turismo. São Paulo: Contexto, 2003.

WEAVER, Warren; SHANNON, Claude. The mathematical theory of communication. Illinois: University of Illinois, 1949.

ZACHARIAS, Andréa. A Representação Gráfica das Unidades de Paisagem no Zoneamento Ambiental: um estudo de caso no município de Ourinhos/SP. Tese (Doutorado em Geografia), Instituto de Geociências e Ciências Exatas, Universidade Estadual de São Paulo, Rio Claro. 2006.

. As Categorias de Análise da Cartografia no Mapeamento e Síntese da Paisagem. Revista Geografia e Pesquisa, v.2, no 1, Ourinhos, 2008. p. 33-56.

Autora: Juliana Colli Munhoz

Contato: juliana_colli@yahoo.com.br 